\title{
THE EARLY CRETACEOUS MESOFOSSIL FLORA OF TORRES VEDRAS (NE OF FORTE DA FORCA), PORTUGAL: A PALAEOFLORISTIC ANALYSIS OF AN EARLY ANGIOSPERM COMMUNITY
}

\author{
ELSE MARIE FRIIS ${ }^{1, *}$, PETER R. CRANE ${ }^{2,3}$, KAJ RAUNSGAARD PEDERSEN ${ }^{4}$ \\ Department of Palaeobiology, Swedish Museum of Natural History, Box 50007, SE-104 05 Stockholm, Sweden; \\ e-mail: else.marie.friis@nrm.se. \\ 2 Oak Spring Garden Foundation, 1776 Loughborough Lane, Upperville, Virginia 20184, USA. \\ ${ }^{3}$ School of Forestry and Environmental Studies, Yale University, New Haven, Connecticut 06511, USA. \\ ${ }^{4}$ Department of Geoscience, University of Aarhus, Høegh-Guldbergs Gade 2, DK-8000 Aarhus C, Denmark. \\ ${ }^{*}$ corresponding author
}

Friis, E. M., Crane, P. R., Pedersen, K. R. (2019): The Early Cretaceous mesofossil flora of Torres Vedras (NE of Forte da Forca), Portugal: a palaeofloristic analysis of an early angiosperm community. - Fossil Imprint, 75(2): 153-257, Praha. ISSN 2533-4030 (print), ISSN 25334069 (on-line).

\begin{abstract}
An Early Cretaceous mesofossil flora is described from the lower part of the Almargem Formation (late Barremianearly Aptian) from Torres Vedras (NE of Forte da Forca), Portugal. The flora is the oldest mesofossil flora containing angiosperm remains to be described in detail based on well-preserved flower, fruit and seed remains. In addition to angiosperms, the mesofossil flora also includes megaspores, sporangia and tiny leaves of spore-bearing plants. There are also twigs, cone fragments and seeds of conifers and seeds assigned to the BEG group. In total about 100 species have been distinguished. Most abundant in terms of plant fragments identified, are spore-bearing plants and conifers. Although only about $18 \%$ of the specimens can be attributed to angiosperms, angiosperm diversity is unexpected high considering the age of the flora. Angiosperms account for about $62 \%$ of all species recognized. Angiosperm diversity is mainly at the level of ANA-grade angiosperms, eumagnoliids and in a few cases early diverging lineages of monocots. Eudicots are subordinate. Twenty new genera and 28 new species of angiosperms are established (Anaspermum operculatum gen. et sp. nov., Appofructus nudus gen. et sp. nov., Appomattoxia minuta sp. nov., Burgeria striata gen. et sp. nov., Canrightia elongata sp. nov., Choffaticarpus compactus gen. et sp. nov., Dejaxia brevicolpites gen. et sp. nov., Dinisia portugallica gen. et sp. nov., Eckhartia brevicolumella gen. et sp. nov., Eckhartia longicolumella sp. nov., Eckhartia intermedia sp. nov., Eckhartianthus lusitanicus gen. et sp. nov., Eckhartiopsis parva gen. et sp. nov., Gastonispermum antiquum sp. nov., Goczania rugosa gen. et sp. nov., Goczania inaequalis sp. nov., Goczania punctata sp. nov., Ibrahimia verminculata gen. et sp. nov., Juhaszia portugallica gen. et sp. nov., Kempia longicolpites gen. et sp. nov., Kvacekispermum costatum sp. nov., Mcdougallia irregularis gen. et sp. nov., Nicholsia brevicolpites gen. et sp. nov., Piercipollis simplex gen. et sp. nov., Reyanthus lusitanicus gen. et sp. nov., Samylinaea punctata gen. et sp. nov., Teebacia hughesii gen. et sp. nov., Vedresia elliptica gen. et sp. nov.). Comparison with results of a palynological study from the same horizon that yielded the mesofossil flora shows a marked underestimation of angiosperm diversity in the palynoflora, a pattern that has also been recognized elsewhere.
\end{abstract}

Key words: early eudicots, fossil flowers, fossil seeds, fossil megaspores, fossil stamens, mesofossil flora, Sergipea, synchrotron radiation X-ray tomographic microscopy (SRXTM), tricolpate pollen

Received: April 4, 2019| Accepted: June 13, 2019 | Issued: November 25, 2019

\section{Introduction}

Palaeobotanical studies of late Mesozoic micro-, mesoand macrofossil floras from all over the world unequivocally document a major floristic transition, during the midCretaceous that was accompanied by significant vegetational changes (Scott et al. 1960, Muller 1970, Doyle and Hickey 1976, Hughes 1976, 1994, Lidgard and Crane 1988, 1990, Crane and Lidgard 1989, Friis et al. 2011, Herendeen et al.
2017). Plant communities in the Late Jurassic and earliest Cretaceous are devoid of angiosperms, but following the Berriasian stage, beginning during the Valanginian and Hauterivian stages of the Early Cretaceous (ca. 140-130 myr BP), unequivocal angiosperm fossils are recognized for the first time (Trevisan 1988, Brenner 1996, Herendeen et al. 2017). Thereafter, the number of angiosperm taxa and their prominence in Cretaceous fossil floras gradually increases, 
and by around the Early/Late Cretaceous boundary (ca. 100 myr BP) angiosperms dominated the vegetation in some environments (Upchurch and Dilcher 1990, Friis et al. 2010b, Harris and Arens 2016) although in terms of global terrestrial biomass production angiosperm dominance may not have been fully attained until the Cainozoic (Wing and Boucher 1998).

During the earliest phases of the angiosperm diversification, around the Barremian - Aptian stages (ca. 130-120 myr BP), angiosperm pollen is rare in palynofloras. This suggests that angiosperms are subordinate in their representation in mid-Early Cretaceous vegetation, but more detailed insights into the systematics and ecology of early angiosperms have been made possible by the discovery of rich Cretaceous mesofossil floras of Barremian - Albian age (for references see Friis et al. 2011). These discoveries show that during this early stage in their evolution angiosperms were more common in some environments than is indicated by coeval palynofloras. They were also surprisingly diverse in terms of numbers of species (diversity in obscurity; Friis et al. 2010b), but very limited in terms of the diversity of modern systematic groups represented.

Mesofossil floras containing abundant well-preserved angiosperm flowers, fruits and seeds extracted from Cretaceous sediments were first recognized around 1980 (Tiffney 1977, Friis and Skarby 1981, Friis 1983, 1984), and the first such mesofossil flora to be studied in detail was of Santonian-Campanian age from Åsen, southern Sweden (Friis 1983, 1984, 1985). Subsequently, an extensive search for similar material in older deposits was initiated by the authors and exploratory fieldwork in eastern North America in 1988, and then in Portugal in 1989, resulted in the discovery of many new localities that yielded rich assemblages of exquisitely preserved plant remains, including a previously unsuspected variety of angiosperm flowers, fruits, seeds and other floral remains, along with megaspores and the fragmentary remains of conifers, chlamydospermous seeds, pteridophytes and bryophytes.

The new localities discovered in Portugal yielded both Early Cretaceous and Late Cretaceous mesofossil floras, but especially important for studies of Early Cretaceous angiosperms are the floras from Arazede, Buarcos, Catefica, Famalicão, Juncal, Torres Vedras, Vale de Água and Vila Verde (e.g. Friis et al. 1994b, 1999, 2010a, Friis et al. 2011). All of these floras are rich in angiosperm remains that are surprisingly diverse at the species level, sometimes including more than 100 different kinds of angiosperm reproductive structures (e.g. the Famalicão mesofossil flora; Eriksson et al. 2000).

Several mesofossil floras (e.g. Arazede, Buarcos, Juncal, Vale de Água) were collected from sediments that are now assigned to the Famalicão and Calvaria members of the Figueira da Foz Formation, which is interpreted to be of late Aptian-early Albian age (Dinis 1999, 2001, Dinis et al. 2002). Our initial analyses of the Early Cretaceous mesofossil floras from Portugal indicated that they were all broadly similar in systematic composition, and probably more or less contemporaneous. Angiosperms in all these mesofossil floras are represented by only small, simple flowers, many small, unilocular and one seeded fruits, and many exotestal and anatropous seeds (Friis et al. 2011). However, with more detailed investigations of the individual fossil assemblages it became increasing clear that different angiosperm species were present at different localities.

One mesofossil flora that stands out as especially distinct among all the angiosperm-containing fossil assemblages that we have studied from Portugal is that from Torres Vedras (NE of Forte da Forca). This mesofossil assemblage was isolated from an organic rich horizon in the lower part of the Almargem Formation, which corresponds to a level below the Figueira da Foz Formation (Rey 1993, Rey et al. 2006). The mesofossil flora is thought to be of late

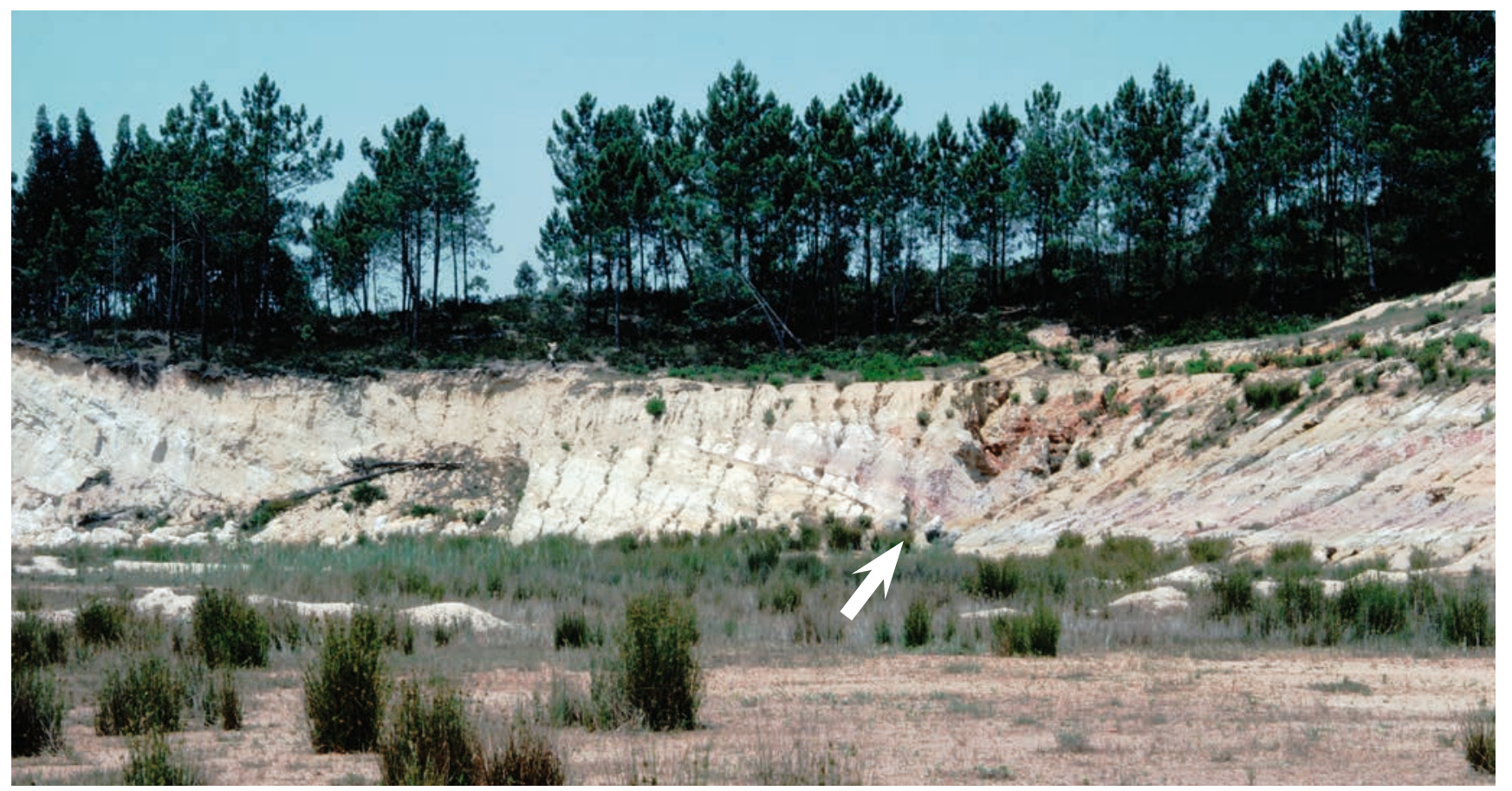

Text-fig. 1. Torres Vedras site. Arrow point to the organic rich horizon where the fossils described here were collected. 
Barremian-early Aptian age and is thus the oldest of the mesofossil assemblages that we have studied that contains angiosperms. Mesofossil floras collected from older rocks in the Portuguese sequence have yielded no angiosperms (Mendes et al. 2011; Friis, Crane and Pedersen, unpublished data). There are also no angiosperms reported from other regions with mesofossil floras from the earliest Cretaceous, including the Carl Nielsen mesofossil flora from Bornholm, Denmark, which is of Berriasian-Valanginian age (Pedersen et al. 1989, Friis and Pedersen 1990), and several Wealdenage mesofossil floras from southern England and Germany (Batten 1998, Scott et al. 1999) that range in age from Berriasian to Barremian.

So far only separate accounts of individual taxa from the Torres Vedras mesofossil flora have been published (Friis et al. 1994b, 1999, 2004, 2009, 2010a, b, 2013, 2014b, 2018 b 2019a) and only a few taxa have been formally described. Here we present a full description of the Torres Vedras mesofossil flora that includes an account of all taxa recognized among the plant fragments extracted from the sediment samples. All plant groups are included, but the descriptions and formal establishment of new taxa focus on the angiosperm elements in the flora. Twenty new genera and 28 new species are described. Basic quantitative analyses are also provided of all specimens from two samples, and the results are compared to palynological counts from samples from the same level carried out by Konradsen (1996).

\section{Locality and geology}

Sediment samples were collected by the authors from a large abandoned sand and clay pit about $1 \mathrm{~km} \mathrm{NE}$ of Forte da
Forca, Torres Vedras, Portugal, (39 $\left.06^{\prime} 13^{\prime \prime} \mathrm{N}, 9^{\circ} 14^{\prime} 47^{\prime \prime} \mathrm{W}\right)$ during repeated visits to the locality over the period 1989 - 1998 (Text-fig. 1). The exposure at Torres Vedras corresponds to the "carrière ouverte $1.5 \mathrm{~km}$ au Nord Est de Torres Vedras" described by Rey $(1972,1993)$. The area is now urbanized and the productive plant-bearing level has been covered by roads and houses. A palynoflora (Casal do Borracho, Torres Vedras) described by Mendes et al. (2018) was collected at the edge of the pit where a small exposure remained. In their geological map Mendes et al. (2018) indicate that this site is in the Fonte Grada Formation (late Hauterivian-early Barremian), but the Casal do Borracho palynoflora is described as being from the lower member of the Almargem Formation (early Barremian-early Aptian).

Prior to urbanization, the sediments exposed at Torres Vedras comprised a thick sequence of fluviatile gravels, sands, silts and clays (Text-fig. 1). Rey (1993) recognized three formations in the exposure: the Lugar d'Alem (Hauterivian), Fonte Grada (late Hauterivian-early Barremian) and Almargem (late Barremian-Aptian) formations (Text-fig. 2). The Almargem Formation is separated into a lower member, assigned to the late Barremian-early Aptian, which is characterized by its predominantly light gray and whitish sediments, and an upper member, assigned in the Torres Vedras area to the Aptian (Rey 1972, 1993) or possibly Aptian-early Albian (Dinis et al. 2008, 2010), which is characterized by its predominantly reddish, bluish and purple sediments. The samples yielding the Torres Vedras mesofossil flora described here were collected below a ferruginous crust in the lower member of the Almargem Formation (late Barremian-early Aptian). A late Barremianearly Aptian age is also supported by the occurrence of many pre-Albian pollen taxa in the mesofossil flora

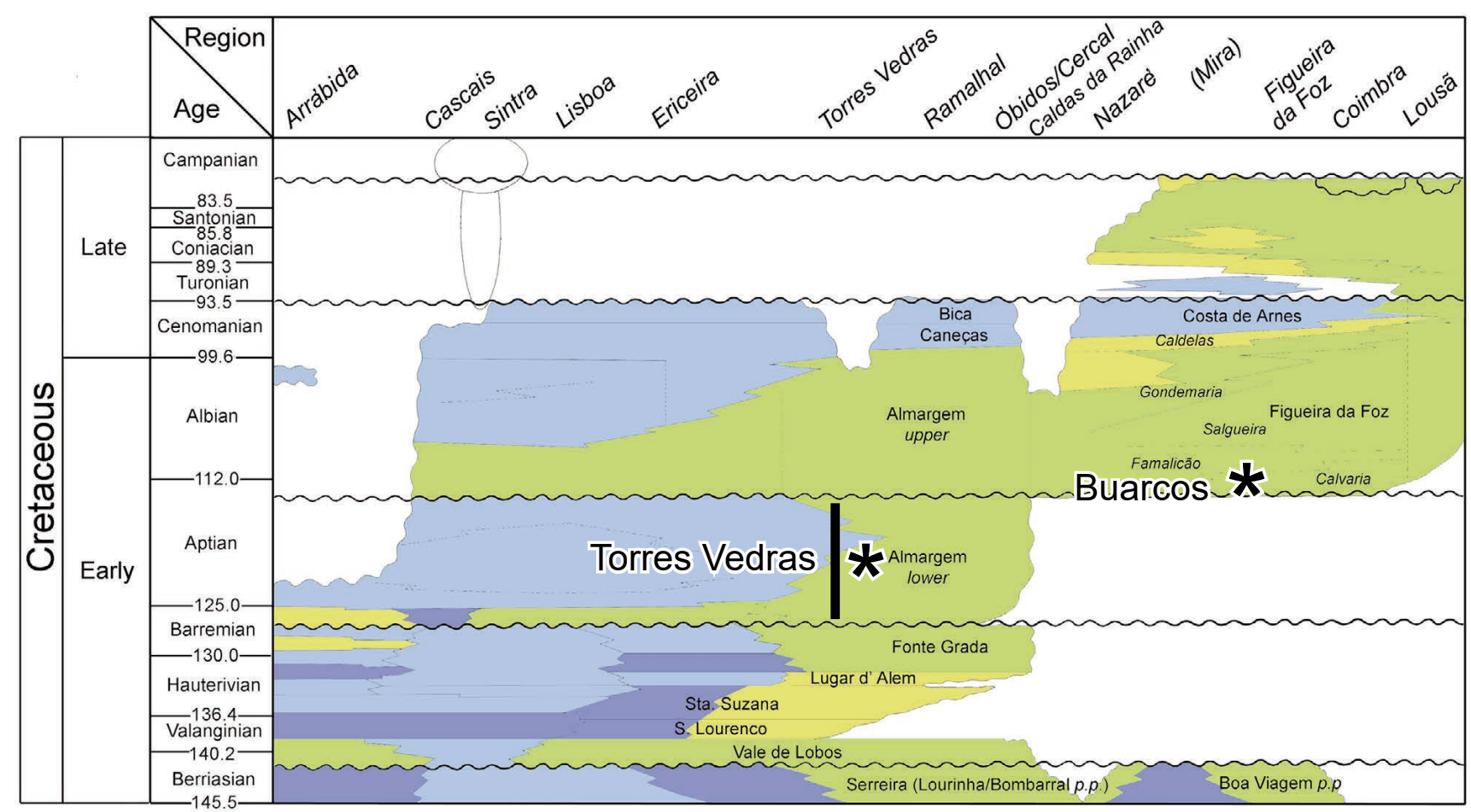

Text-fig. 2. Portuguese Early Cretaceous formations in the Torres Vedras and in the Figueira da Foz region. The Torres Vedras mesofossil flora was collected in the lower Almargem Formation. The Buarcos mesofossil flora, and several other younger mesofossil floras from Portugal, are from the lower part of the Figueira da Foz Formation. Based on information in Rey et al. (2006). 
including Sergipea, that in Europe is reported only from the Barremian stratotype (Renéville and Raynaud 1981). Many of the monocolpate pollen types from Torres Vedras further correspond to pollen from the Valanginian - late Hauterivian/ early Barremian of southern Tuscany (L. Trevisan, work in progress and personal communication 2018, 2019).

In their studies of Early Cretaceous sediments exposed in Portuguese coastal sections Heimhofer (2004) and Heimhofer et al. (2007) provided a stratigraphic crosssection through the Lusitanian basin that placed the Torres Vedras mesofossil flora in the early-middle Albian. None of the mesofossil sites in the Lusitanian Basin, including the Torres Vedras sequence, was analyzed by these authors, but the Torres Vedras mesofossil flora was assumed to be contemporaneous with mesofossil floras from the Figueira da Foz Formation, including the Buarcos mesofossil flora. Heimhofer (2004) and Heimhofer et al. (2007) regarded the mesofossil floras from the Figueira da Foz Formation as of Albian age referring to an early palynological study by Groot and Groot (1962) from the Buarcos-Tavarede region. However, the palynological content of the mesofossil flora reported here, as well as the palynological assemblages from the same horizons as the Torres Vedras mesofossil flora (Konradsen 1996), lack typical younger (Albian) elements and are more similar to palynofloras from the older (Aptian) parts of the coastal sections.

Also significant is that the key palynological study by Groot and Groot (1962) considered only two late Cenomanian samples of unknown provenance from the Buarcos-Tavarede region. Those samples were clearly not from any of the sites from which we have studied mesofossils. They are also very different from the Buarcos palynoflora described from the Figueira da Foz Formation (Pais and Reyre 1981) and the pollen content of the mesofossil remains that we have collected from the Buarcos site, only a few of which have been published (Friis et al. 1997, 1999, 2015b, 2017, 2019b, Friis and Pedersen 2011). Notably, the angiosperm pollen in the Groot and Groot samples are all tricolpate or tricolporate forms and include two species of Latipollis, a typical genus of the Late Cretaceous - Early Cainozoic Normapolles group that does not occur in any Early Cretaceous palynofloras. No tricolpate pollen was observed in our study of the mesofossil flora or the palynoflora from the Buarcos site.

\section{Material and methods}

\section{Sampling}

The most productive samples for mesofossils from the Torres Vedras locality were collected from a laterally restricted, organic rich, lens of sand and gravel, about 50$100 \mathrm{~cm}$ thick, which contained larger pieces of wood as well as mesofossils. For each sample, typically 2-4 kilograms of sediment were collected. Most of the plant fossils are lignitised, often with homogenized cell walls. Sometimes all the plant tissues are homogenized and no cellular details are preserved. Charcoalified specimens with good cellular preservation are rare in the Torres Vedras samples.

Samples were also collected for mesofossils above and below the organic rich lens. These proved to be low in diversity, and very poor, in terms of the number of specimens recovered and their preservation. For clarity, and also to provide a detailed account of the plants at a single restricted stratigraphic level, we have confined the account given here to the single organic rich lens from the lower member of the Almargem Formation, which yielded the most diverse and best-preserved plant fossil assemblage.

\section{Preparation and examination}

Larger pieces of wood were removed before further preparation. The samples were disaggregated and sieved in water over a $125 \mu \mathrm{m}$ mesh sieve. The sediment residue and the finer organic material passing through the sieve were collected on paper filters and checked for finer plant remains. Fossils caught by the sieve were cleaned using $40 \%$ $\mathrm{HF}$ and $10 \% \mathrm{HCl}$, thoroughly rinsed in water, dried in air and sorted under a binocular microscope.

In all cases the organic residues remaining after processing of the samples consist of tiny plant fragments, most of which are unidentifiable fragments of wood, stems and cuticle. Recognizable plant fragments, such as megaspores, sporangia, twigs and tiny leaves, seed, fruits, stamens and flowers are very rare within the organic residues. Sorting of all mesofossil floras that we collected was done by ourselves thereby reducing bias in the recognition of different kinds of fossils in different samples.

For studies using scanning electron microscopy (SEM) and synchrotron attenuation-based synchrotron radiation X-ray tomographic microscopy (SRXTM) fossils were mounted on metal stubs using nail polish. Specimens for SEM were coated with gold and studied using a Hitachi S-4300 field emission or Phillips 515 scanning electron microscope.

Specimens for SRXTM were mounted without further treatment and analyzed at the TOMCAT beamline of the Swiss Light Source of the Paul Scherrer Institute, Villigen, Switzerland (Stampanoni et al. 2006, Friis et al. 2014a). The analyses were carried out mostly at $10 \mathrm{keV}$ with a sCMOS detector and a $20 \mu \mathrm{m}$ thick LAG:Ce scintillator screen using a $10 \times$ (isotopic pixel size 0.75 and $0.65 \mu \mathrm{m}$ ) or $20 \times$ (isotopic pixel size $0.325 \mu \mathrm{m}$ ) objective over $180^{\circ}$. Examination of specimen S136725 (Choffaticarpus compactus) was done using horizontal two-fold expansion with projections over $360^{\circ}$ (for details see Friis et al. 2014a).

Reconstructions of SRXTM data were made using Avizo software. An even black background for SEM images was made using Photoshop.

\section{Counts}

Our study focused on the angiosperm components of the mesofossil flora, as well as the chlamydospermous seeds of non-angiosperm seed plants (the BEG group). Determinations of taxa belonging to these two groups are at the species level whenever possible. Systematic assignments of spore-bearing plants and conifers are made mostly at the generic or higher levels. Stem fragments and leaves of bryophytes, lycopodiopsids, fern and conifer twigs are not described as separate taxa.

The species list (Tab. 1) is based on all productive samples collected at the same level from the organic rich lens in the 
Table 1. Mesofossils recognized in 11 samples collected very close to each other within the same organic rich horizon at the Torres Vedras locality (Torres Vedras samples TV38, TV39, TV43, TV44, TV142, TV143, TV144, TV145, TV217, TV298, TV299). The total number of specimens is counted for samples TV43 and TV44, while for the other samples only the presence of a taxon is recorded (x).

\begin{tabular}{|c|c|c|c|c|c|c|c|c|c|c|c|}
\hline Fossil/Torres Vedras samples & TV38 & TV39 & TV43 & TV44 & TV142 & TV143 & TV144 & TV145 & TV217 & TV298 & TV299 \\
\hline Charophyta sp. & $\mathbf{x}$ & & & & & & $\mathbf{x}$ & & & & \\
\hline Moss leafy axes & & & 18 & 1 & & & & & & $\mathbf{x}$ & \\
\hline Marchantialean liverworts & & & 70 & & & & & & & $\mathbf{x}$ & \\
\hline Selaginellaceae axes & & & $\mathbf{5 0}$ & 1 & & & & & & $\mathbf{x}$ & $\mathbf{x}$ \\
\hline Fern axes and sporangia & & & 4 & 79 & & & & & & & \\
\hline aff. Flabellisporites sp. & $\mathbf{x}$ & & 5 & & & & $\mathbf{x}$ & $\mathbf{x}$ & & & \\
\hline Cabochonicus carbunculus & & $\mathbf{x}$ & 2 & 4 & $\mathbf{x}$ & & $\mathbf{x}$ & $\mathbf{x}$ & $\mathbf{x}$ & & \\
\hline Dijkstraisporites sp. & $\mathbf{x}$ & & 4 & 2 & $\mathbf{x}$ & $\mathbf{x}$ & $\mathbf{x}$ & $\mathbf{x}$ & & & \\
\hline Erlansonisporites sp. & $\mathbf{x}$ & & 2 & 94 & $\mathbf{x}$ & $\mathbf{x}$ & $\mathbf{x}$ & $\mathbf{x}$ & $\mathbf{x}$ & $\mathbf{x}$ & $\mathbf{x}$ \\
\hline Hughesisporites galericulatus & $\mathbf{x}$ & $\mathbf{x}$ & 11 & 15 & $\mathbf{x}$ & $\mathbf{x}$ & $\mathbf{x}$ & $\mathbf{x}$ & $\mathbf{x}$ & $\mathbf{x}$ & \\
\hline Megaspore sp. 1 & & & & 1 & & & & & & & \\
\hline Megaspore sp. 2 & & & 2 & 3 & & & & & $\mathbf{x}$ & & \\
\hline Megaspore sp. 3 & & & 6 & 3 & & $\mathbf{x}$ & $\mathbf{x}$ & $\mathbf{x}$ & $\mathbf{x}$ & & \\
\hline Paxillitriletes reticulatus & & & & 2 & $\mathbf{x}$ & & $\mathbf{x}$ & & & & \\
\hline Rugotriletes sp. & $\mathbf{x}$ & $\mathbf{x}$ & 17 & 42 & $\mathbf{x}$ & $\mathbf{x}$ & $\mathbf{x}$ & $\mathbf{x}$ & $\mathbf{x}$ & & \\
\hline Striatriletes spp. & & $\mathbf{x}$ & & 54 & & $\mathbf{x}$ & $\mathbf{x}$ & & $\mathbf{x}$ & & \\
\hline Tenellisporites sp. & $\mathbf{x}$ & & 3 & 11 & $\mathbf{x}$ & $\mathbf{x}$ & $\mathbf{x}$ & $\mathbf{x}$ & $\mathbf{x}$ & & \\
\hline Trileites spp. & & & 4 & 38 & $\mathbf{x}$ & $\mathbf{x}$ & $\mathbf{x}$ & $\mathbf{x}$ & $\mathbf{x}$ & $\mathbf{x}$ & \\
\hline Verrutriletes sp. & & & 2 & 1 & & & $\mathbf{x}$ & & & $\mathbf{x}$ & \\
\hline Molaspora sp. & $\mathbf{x}$ & $\mathbf{x}$ & & & & & $\mathbf{x}$ & & & & \\
\hline Arcellites punctatus & $\mathbf{x}$ & $\mathbf{x}$ & 15 & & $\mathbf{x}$ & $\mathbf{x}$ & $\mathbf{x}$ & $\mathbf{x}$ & $\mathbf{x}$ & & \\
\hline Cicatricosisporites ventusus & & & 1 & & & & & & & & \\
\hline Cicatricosisporites sp. 1 & & & 1 & & & & & & & & \\
\hline Cicatricosisporites sp. 2 & & & 1 & 1 & & & & & & & \\
\hline Cyathidites australis & & & 2 & 3 & & & & & & & \\
\hline Cyathidites minor & & $\mathbf{x}$ & & 4 & & & & & & & \\
\hline Densoisporites $\mathbf{s p .}$ & & & 2 & & & & & & & & \\
\hline Patellasporites cf. tavaredensis & & & 4 & 3 & & & & & & & \\
\hline Taurocusporites segmentatus & & & & 1 & & & & & & & \\
\hline Coniferales axes, cone scales & & & 160 & 95 & $\mathbf{x}$ & $\mathbf{x}$ & $\mathbf{x}$ & $\mathbf{x}$ & $\mathbf{x}$ & $\mathbf{x}$ & $\mathbf{x}$ \\
\hline Coniferales bisaccate pollen & & $\mathbf{x}$ & & 2 & & & & & & & \\
\hline Coniferales seed spp. & $\mathbf{x}$ & & 168 & 78 & $\mathbf{x}$ & $\mathbf{x}$ & $\mathbf{x}$ & $\mathbf{x}$ & & $\mathbf{x}$ & $\mathbf{x}$ \\
\hline Araucariacites sp. & & & 2 & 7 & & & & & & & \\
\hline Pseudofrenelopsis sp. & & & & 1 & & & & & & & \\
\hline Buarcospermum tetragonium & & & 1 & & & & & & & & \\
\hline Ephedrispermum lusitanicum & & & 175 & 1 & & & & & & & \\
\hline Quadrispermum parvum & & $\mathbf{x}$ & 126 & 1 & & & & & & & \\
\hline Tomcatia taylorii & $\mathbf{x}$ & & 5 & 1 & & & & & & & \\
\hline Sergipea sp. & & & & 1 & & & & & & & \\
\hline Monoporate pollen incertae sedis & & & & 1 & & & & & & & \\
\hline Indet. spore or pollen & & & & 1 & & & & & & & \\
\hline Anaspermum operculatum & $\mathbf{x}$ & & 16 & & & & $\mathbf{x}$ & & & & \\
\hline Angiosperm follicle sp. 1 & & & 1 & & & & & & & & \\
\hline Angiosperm follicle sp. 2 & & & & 1 & & & & & & & \\
\hline Angiosperm seed sp. 1 & & & 1 & & & & & & & & \\
\hline Angiosperm seed sp. 2 & & & 1 & & & & & & & & \\
\hline Angiosperm seed sp. 3 & & & 2 & & $\mathbf{x}$ & $\mathbf{x}$ & & $\mathbf{x}$ & & & \\
\hline Angiosperm seed sp. 4 & $\mathbf{x}$ & & & & & & & & & & \\
\hline Angiosperm seed sp. 5 & & & & 5 & & & $\mathbf{x}$ & & & & \\
\hline Appofructus nudus & & & & 7 & & & & & & & \\
\hline Appofructus sp. & $\mathbf{x}$ & & & & & & & & & & \\
\hline Appomattoxia minuta & & & 1 & 4 & & & & & & & \\
\hline
\end{tabular}


Table 1. continued

\begin{tabular}{|c|c|c|c|c|c|c|c|c|c|c|c|}
\hline Fossil/Torres Vedras samples & TV38 & TV39 & TV43 & TV44 & TV142 & TV143 & TV144 & TV145 & TV217 & TV298 & TV299 \\
\hline Asteropollis - tetrachotomocolpate & & & & 4 & & & & & & & \\
\hline Asteropollis - trichotomocolpate & & & & 11 & & & & & & & \\
\hline Burgeria striata & & $\mathbf{x}$ & & 2 & & & & & & & \\
\hline Canrightia elongata & $\mathbf{x}$ & & & & & & & & & & \\
\hline Canrightia sp. & & & 6 & & $\mathbf{x}$ & & & & & & \\
\hline Choffaticarpus compactus & & & 2 & 1 & & & & & & & \\
\hline Clavatipollenites sp. 1 & & & & 3 & & & & & & & \\
\hline Clavatipollenites sp. 2 & & & 1 & & & & & & & & \\
\hline Clavatipollenites sp. 3 & & & & 3 & & & & & & & \\
\hline Clavatipollenites unassigned & & & 1 & 9 & $\mathbf{x}$ & & & & & & \\
\hline Dejaxia brevicolpites & & & & 1 & & & & & & & \\
\hline Dictyozonia pusilla & & & & & & & $\mathbf{x}$ & & & & \\
\hline Dinisia portugallica & & & & 3 & & & & & & & \\
\hline Eckhartia brevicolumella & & & & 12 & $\mathbf{x}$ & & & & & & \\
\hline Eckhartia intermedia & & & 1 & & & & & & & & \\
\hline Eckhartia longicolumella & & & & 2 & & & & & & & \\
\hline Eckhartia sp. & & & & 2 & & & & & & & \\
\hline Eckhartianthus lusitanicus & & $\mathbf{x}$ & & & & & & & & & \\
\hline Eckhartiopsis parva & & $\mathbf{x}$ & & & & & & & & & \\
\hline Gastonispermum antiquum & & & 4 & 2 & & & & & & $\mathbf{x}$ & \\
\hline Goczania rugosa & & & 1 & 2 & $\mathbf{x}$ & & & & & & \\
\hline Goczania inaequalis & & $\mathbf{x}$ & & 6 & & & & & & & \\
\hline Goczania punctata & & & & 1 & & & & & & & \\
\hline Hedyflora sp. 1 & & & 16 & 1 & $\mathbf{x}$ & & & $\mathbf{x}$ & & & \\
\hline Hedyflora sp. 2 & & & 1 & 3 & & & & & & & \\
\hline Ibrahimia vermiculata & & & & 3 & & & & & & & \\
\hline Juhaszia portugallica & & & & 1 & & & & & & & \\
\hline Kempia longicolpites & & & & 1 & & & & & & & \\
\hline Kvacekispermum costatum & $\mathbf{x}$ & & & & & & & & & & \\
\hline Kvacekispermum sp. & $\mathbf{x}$ & & & & & & & & & & \\
\hline Mayoa portugallica & & & & 1 & & & & & & & \\
\hline Mcdougallia irregularis & & & 1 & & & & & & & & \\
\hline Nicholsia brevicolpites & & & & 1 & & & & & & & \\
\hline Nymphaeales-Austrobaileyales sp. 1 & & & 1 & & & & & & & & \\
\hline Nymphaeales-Austrobaileyales sp. 2 & & & & 1 & & & & & & & \\
\hline Nymphaeales-Austrobaileyales sp. 3 & & & 1 & & & & & & & & \\
\hline Pantoporate pollen & & & & & $\mathbf{x}$ & & & & & & \\
\hline Pazliopsis reyi & $\mathbf{x}$ & & 5 & 35 & $\mathbf{x}$ & & $\mathbf{x}$ & & & $\mathbf{x}$ & $\mathbf{x}$ \\
\hline Pennicarpus sp. & $\mathbf{x}$ & & & & & & $\mathbf{x}$ & & & & \\
\hline Pennipollis sp. & & & & 2 & & & & & & & \\
\hline Piercipollis simplex & & & & 4 & & & & & & & \\
\hline Piercipollis sp. 1 & & & & 1 & & & & & & & \\
\hline Piercipollis sp. 2 & & & & & $\mathbf{x}$ & & & & & & \\
\hline Reticulate foveolate pollen & & & & 2 & & & & & & & \\
\hline Reticulate pollen - sharp muri & & & & 2 & & & & & & & \\
\hline Reyanthus lusitanicus & & & & & & & & & & & $\mathbf{x}$ \\
\hline Samylinaea punctata & & & & 1 & & & & & & & \\
\hline Serialis antiqua & & & 19 & 6 & & & & & $\mathbf{x}$ & & $\mathbf{x}$ \\
\hline Serialis parva & & & 58 & & & & & & & $\mathbf{x}$ & \\
\hline Serialis unassigned & & & & 2 & $\mathbf{x}$ & $\mathbf{x}$ & $\mathbf{x}$ & & & $\mathbf{x}$ & \\
\hline Tectate pollen from coprolite & & & & 1 & & & & & & & \\
\hline Tectate-punctate from coprolite & & & 2 & 2 & & & & & & & \\
\hline Teebacia hughesii & & & & 12 & & & & & & & \\
\hline Wedge-shaped angiosperm fruit & & & 1 & 1 & & & & & & & \\
\hline Vedrasia elliptica & & & 1 & & & & & & & & \\
\hline
\end{tabular}


lower member of the Almargem Formation (Torres Vedras samples TV38, TV39, TV43, TV44, TV142, TV143, TV144, TV145, TV217, TV298, TV299). For quantitative analyses all specimens with recognizable botanical features, including coprolites with spores or pollen, megaspores, pollen and spore lumps, isolated sporangia or groups of sporangia, anthers and stamens, flowers, fruits and seeds, as well as twigs and leaf fragments, were counted for two samples. These two samples (Torres Vedras samples 43 and 44; Tab. 1, Text-fig. 56) were collected close to each other in the lignitic lens. The composition of the mesofossil flora is compared with results from palynological analyses carried out on samples collected from the same organic rich lens in the lower member of the Almargem Formation (Konradsen 1996).

\section{Terminology}

Descriptions of spores and pollen mainly use the terminology of Punt et al. (2007). Descriptions of ovules/ seeds use the terminology of Corner (1976). Whenever possible we discriminate between exotestal, mesotestal, endotestal, exotegmic, mesotegmic and endotegmic seeds, based on the specific integumentary layers that contribute to the mechanical (hard) tissues of the mature seed coat. For explanation of this approach and its associated terminology, which derives mainly from the work of Corner, see Schmid (1986). Understanding the developmental origin of specific seed coat layers is best done by studies of ovule/seed ontogeny. However, even though one or more tissue layers in the seed coat may be crushed during seed development, in most cases the major seed categories can still be distinguished at maturity. This is also the case for fossil seeds, which are typically mature and preserved after seed dispersal. We adopt this approach in our descriptions of seed coat features and our identifications of the various seed categories. Ultimately, these descriptions are based on comparisons with the seeds of extant angiosperms, including those for which developmental series are well documented (e.g. Corner 1976, Takhtajan 1985, 1988, 1991, 1992, 1996, 2000).

\section{Fossil material}

The fossil material and raw data from the SRXTM examinations are stored at the Swedish Museum of Natural History, Stockholm (S numbers). New names of fossil plants are registered in the Plant Fossil Names Registry, which is hosted and operated by the National Museum, Prague for the International Organisation of Palaeobotany (IOP), each with a unique PFN number.

\section{Systematic palaeobotany}

\section{Division Charophyta Migula, 1890 \\ Isolated oospore Text-fig. $3 \mathrm{a}$}

Description and remarks. Four oospores were recovered from the Torres Vedras mesofossil flora. They are elliptical in lateral view, with a maximum diameter in transverse section of about $375 \mu \mathrm{m}$, and show five sharp, spirally arranged ridges (Text-fig. 3a).
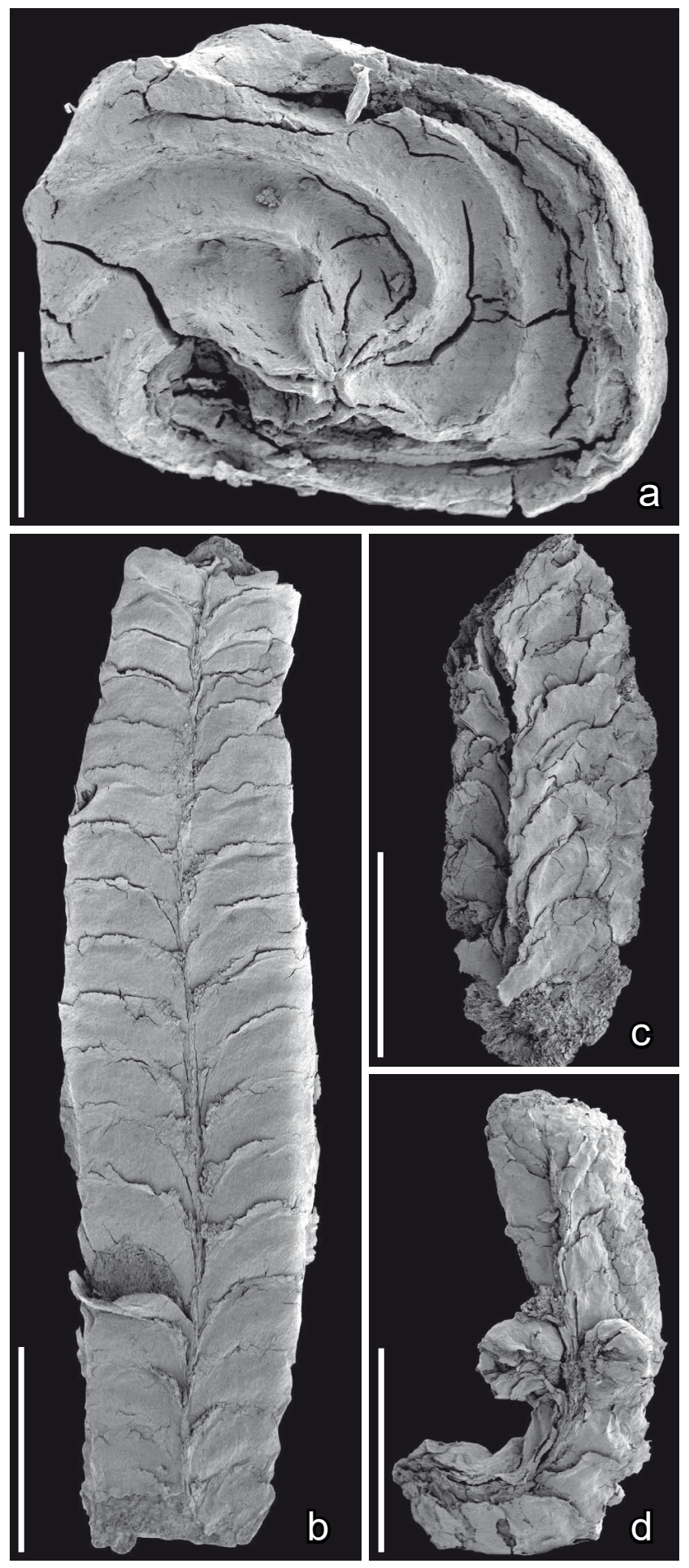

Text-fig. 3. Scanning electron microscope (SEM) images of a charalean oospore (a), and fragments of probable marchantialean liverwort thalli (b-d); Torres Vedras locality, Portugal. a) Apical view of oospore showing the pattern of spiral ridges and grooves resulting from the enclosing cells of the oogonium. b-d) Thallus fragments in probable ventral view showing two rows of imbricate scales and occasional branching of the thallus (d). Specimens, TV38-S174607 (a), TV43-S174655 (b), TV43-S174654 (c), TV43-S174661 (d). Scale bars $1 \mathrm{~mm}$ (b-d), $100 \mu \mathrm{m}$ (a).

Affinity and other occurrences. The characters of the fossils clearly indicate affinity to the freshwater stonewort family Characeae. The specimens 

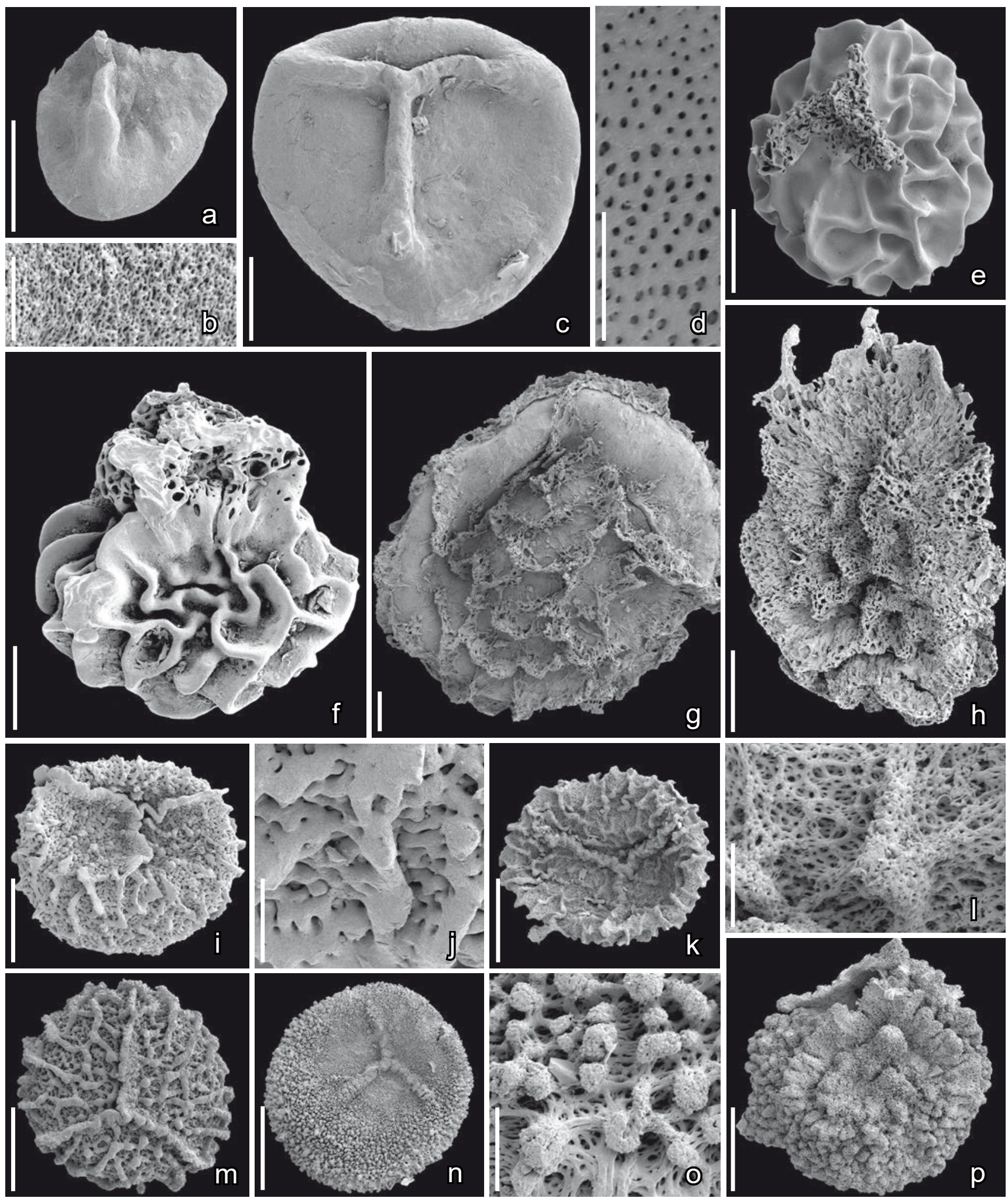

Text-fig. 4. Scanning electron microscope (SEM) images of megaspores with possible affinities to Selaginellales; Torres Vedras locality, Portugal. a, b) Hughesisporites galericulatus, lateral view of megaspore (a) with almost smooth surface and spore wall of thin elements forming a dense reticulum (b); c) Trileites sp., proximal view of megaspore with almost smooth surface and raised trilete mark; d-f) Rugotriletes sp., proximal (e) and lateral (f) views of megaspores showing coarsely reticulate-rugulate surface ornamentation and prominent gula around the trilete mark and compact perforate spore wall (d); g, h) Erlansonisporites sp., distal (g) and lateral (h) views of megaspores showing coarsely reticulate-rugulate surface and fibrous spore wall; $\mathbf{i}$, j) Striatriletes sp. 1, megaspore in oblique proximal view (i) showing raised laesurae and irregular striate-rugulate surface, and detail of spore wall (j) showing dense packing of sculptural elements; k, l) Striatriletes sp. 2, megaspore in proximal view (k) showing trilete mark, striate-rugulate surface, and detail of spore wall (l) composed of loosely packed fibers; $\mathrm{m}$ ) Striatriletes sp. 3, megaspore in proximal view showing raised trilete mark and striate-rugulate surface; $n$, o) Verrutriletes sp., megaspore in oblique proximal view (n) showing short laesurae of the trilete mark, and the dense verrucate surface (o); p) Megaspore sp. 1, oblique proximal view showing 
are poorly preserved and have not been analysed in detail. These are currently the only oospores recovered from all of the mesofossil floras that we have examined from the Early Cretaceous of Portugal.

Division Marchantiophyta Stotler et Crand.-Stotl., 1977 emended by Crandall-Stotler and Stotler (2000)

Order Marchantiales LIMPR., 1877 Text-fig. 3b-d

Description and remarks. The Torres Vedras mesofossil flora includes several fragments of small flattened axes (thallus fragments) that show occasional lateral branches. The thalli have one surface (probably ventral) covered by two rows of imbricate scales (Textfig. $3 b-d)$. The other surface is irregular and more or less smooth. SRXTM has revealed well-preserved internal cellular details.

Affinity and other occurrences. These kinds of axes are known from most of the Early Cretaceous mesofossil floras of Portugal and eastern North America studied by us and are sometimes abundant. Their almost invariable presence in the Early Cretaceous mesofossil floras that we have examined is in distinct contrast to their absence from similar Late Cretaceous mesofossil floras. The axes closely resemble the thalli of marchantialean liverworts, which often have imbricate scales in two rows on the ventral surface (e.g. McCohana 1941). More detailed systematic comparisons of this and similar Early Cretaceous material with extant Marchantiales will be the focus of a separate report.

\section{Division Bryophyta Schimp., 1876}

Description and remarks. The Torres Vedras mesofossil flora includes several small fragments of tiny axes with long narrow leaves attached in a spiral arrangement (not shown).

Affinity and other occurrences. These kinds of delicate leafy axes occur in several other mesofossil floras and are particularly common and well-preserved in the Catefica mesofossil flora. Some of the Catefica fossils that have been studied using SRXTM closely resemble leafy axes of the extant moss Polytrichum. More detailed studies of this and similar Early Cretaceous material, including systematic comparisons with extant mosses, are needed.

\section{Division Tracheophyta SinnotT ex Caval.-SM., 1998 Class Lycopodiopsida BARTL., 1830}

\section{Selaginellalean and isoetalean megaspores}

Remarks. Under this heading we illustrate lycopodiopsid megaspores and associated microspores of probable selaginellalean and isoetalean affinity. The morphology of the megaspores has been studied using SEM, and many specimens have also been studied using SRXTM for details of wall structure. Only brief accounts of the morphological diversity of selaginellalean and isoetalean megaspores are presented here. More detailed descriptions and comparisons are beyond the scope of this treatment. Selaginellalean plants are also represented in the Torres Vedras mesofossil flora by fragments of small leafy axes with leaves that are decussate and oppositely arranged. Some of these axes are distinctly bilaterally symmetrical and exhibit clear heterophylly (not shown).

\section{Genus Hughesisporites R.PотоNiÉ, 1956}

\section{Hughesisporites galericulatus (DIJKSTRA) R.POTONIÉ, 1956 Text-fig. 4a, b}

Description and remarks. Megaspores are azonate and have a circular equatorial outline. The trilete mark is indistinct. The surface is almost smooth with small rounded verrucae near the proximal pole (Text-fig. 4a). The megaspore wall is composed of densely spaced elements that form a fine reticulum (Text-fig. 4b).

Affinity and other oc currences. Megaspores of Hughesisporites galericulatus also occur at the Catefica locality, but are not known from other Portuguese mesofossil floras. However, they are common in many deposits from the earliest Cretaceous (e.g. Potonié 1956, Batten and Kovach 1990, Koppelhus and Batten 1992). Their systematic affinity is unknown.

\section{Genus Trileites Erdtman ex R.Potonié, 1956}

\section{Trileites sp.}

Text-fig. $4 \mathrm{c}$

Description and remarks. The Torres Vedras mesofossil flora includes a variety of almost smooth trilete and azonate megaspores with a trilete mark that is more or less raised (Text-fig. 4c). Whether these megaspores represent different developmental stages, and/or different preservation states, of a single natural species, or whether more than one species is present, is unknown.

Affinity and other occurrences. These kinds of plain Trileites megaspores are widespread in Mesozoic rocks (Batten and Kovach 1990) and are also known from other Early Cretaceous mesofossil floras from Portugal. They are thought to have been produced by plants of selaginellalean affinity because of the tightly interconnected granular elements of the exospore observed in well-preserved specimens (Koppelhus and Batten 1989).

\section{Genus Rugotriletes Hammen ex R.Potonié, 1956 Rugotriletes sp. Text-fig. 4d-f}

Description and remarks. Megaspores are trilete, azonate, with a coarsely reticulate-rugose surface with smooth, rounded ridges (Text-fig. 4e, f). There is a distinct gula that may be intact (Text-fig. 4f) or abraded 
exposing the trilete mark (Text-fig. 4e). The outer part of the megaspore wall is densely punctate (Text-fig. 4d).

Affinity and other occurrences. Megaspores assigned to Rugotriletes are common in the Torres Vedras mesofossil flora. In their reticulate-rugose surface, and the presence of a distinct gula, they are similar to megaspores of Rugotriletes dictyotus HAMmen ex R.Potonié described from the Late Cretaceous of the Netherlands (Potonié 1956). There is also some resemblance to species of Erlansonisporites, but these lack a pronounced gula and the outer part of the megaspore wall is composed of loose, rather than densely packed fibers. Rugotriletes megaspores are also known from several other mesofossil floras in Portugal, but the Torres Vedras megaspores differ in the rounded profiles of the ridges. It seems likely that several species of Rugotriletes are present in the Early Cretaceous of Portugal. Their systematic affinity is uncertain, but they were probably produced of plants of selaginellalean affinity.

\section{Genus Erlansonisporites R.PotoniÉ, 1956}

\section{Erlansonisporites sp.} Text-fig. $4 \mathrm{~g}, \mathrm{~h}$

Description and remarks. Megaspores are trilete, azonate with an irregularly reticulate outer spore wall formed from loosely packed fibers that form a foveolate network (Text-fig. 4g, h). The reticulum is loosely attached to the main body of the megaspore and the megaspores are often naked or have only very little of the outer spore wall preserved. The main spore body is often iridescent blue-green reflecting the opal-like internal structure of the megaspore wall. There is some variation in size of these megaspores and the exact form of the reticulum. It is unknown whether these are variants of a single species or whether more than one species is present.

Affinity and other occurrences. Megaspores of Erlansonisporites occur only sporadically in the Torres Vedras mesofossil flora, whereas they are common in most other Early Cretaceous mesofossil floras from Portugal. In particular, there are many well-preserved specimens in the Arazede, Buarcos and Famalicão mesofossil floras. The Torres Vedras specimens are smaller with taller muri forming the reticulum and probably do not belong to the common form of Erlansonisporites that occurs in the other Portuguese floras.

Erlansonisporites is common in Early and Late Cretaceous floras from many regions and a large number of species have been recognized (Batten and Kovach 1990). Erlansonisporites megaspores are usually easily recognized by their opal-like iridescent wall, which results from a regular internal arrangement of densely spaced elements. Similar wall structure occurs in the megaspores of many species of extant Selaginella P.Beauv. (e.g. Hueber 1982, Hemsley and Collinson 2008).

\section{Genus Striatriletes Hammen ex R.PotoniÉ, 1956}

\section{Striatriletes spp.}

Text-fig. 4i-m

Description and remarks. Several kinds of small trilete and azonate megaspores that have distinctly raised laesurae and irregular rugulate-striate ornamentation occur in the Torres Vedras mesofossil flora. Three different forms, probably belonging to three different species, are illustrated here (Text-fig. 4i-m), but the number of species in the flora may be higher. The three forms are distinguished from each other mainly in the structure of the spore wall that may be composed of broad elongate elements that are densely packed and interwoven (Text-fig. 4i, j) or narrower fibriform elements that are interwoven into a loose network (Text-fig. 4k, 1).

Affinity and other occurrences. All three forms recognized in the Torres Vedras mesofossil flora are closely similar in gross morphology to Striatriletes sulcatus (DiJKstra) R.Potonié, the type species of this genus of megaspore. The species was first described from the Hauterivian-Barremian of the Kingsclere Borehole, southern England (Dijkstra 1951, Potonié 1956) and has also been reported from the Barremian of the Smokejacks Brickworks, also in southern England (Nye et al. 2008). Details of the spore wall have not been illustrated for any of this material. In the Portuguese mesofossil floras, megaspores assignable to Striatriletes are most common in the Torres Vedras mesofossil flora, but also occur sporadically in mesofossil floras from other localities, such as Buarcos and Famalicão.

\section{Genus Verrutriletes (DiJKstra) R.Potonié, 1956}

\section{Verrutriletes sp. \\ Text-fig. 4n, o}

Description and remarks. Megaspores are trilete and azonate with short laesurae and verrucate surface ornamentation (Text-fig. 4n, o). The outer megaspore wall consists of irregular, elongated, fibriform elements that form a loose network as well as the surface sculpture of rounded verrucae (Text-fig. 4o).

Affinity and other occurrences. Megaspores resembling forms assigned here to Verrutriletes $\mathrm{sp}$. are rare in the Torres Vedras mesofossil flora, and are currently unknown from other Early Cretaceous mesofossil floras from Portugal. However, we have been unable to match the megaspores from Torres Vedras with any existing species. Verrutriletes is a heterogeneous genus and its delimitation from other fossil megaspore genera is not clear.

\section{Genus Cabochonicus Batten et D.J.P.Ferguson, 1987}

\section{Cabochonicus carbunculus (DIJKSTRA) BATTEN et D.J.P.Ferguson, 1987}

Description and remarks. Megaspores are trilete and azonate with a smooth, shiny surface ornamented by irregularly spaced spherical elements (not shown).

Affinity and other occurrences. Cabochonicus carbunculus is a long ranging species, and perhaps because of its very characteristic morphology, large size and distinctive compact spore wall, has been widely reported from many fossil floras. In the Torres Vedras mesofossil flora the species is represented by only a few, often poorly preserved, specimens. In other Early Cretaceous 

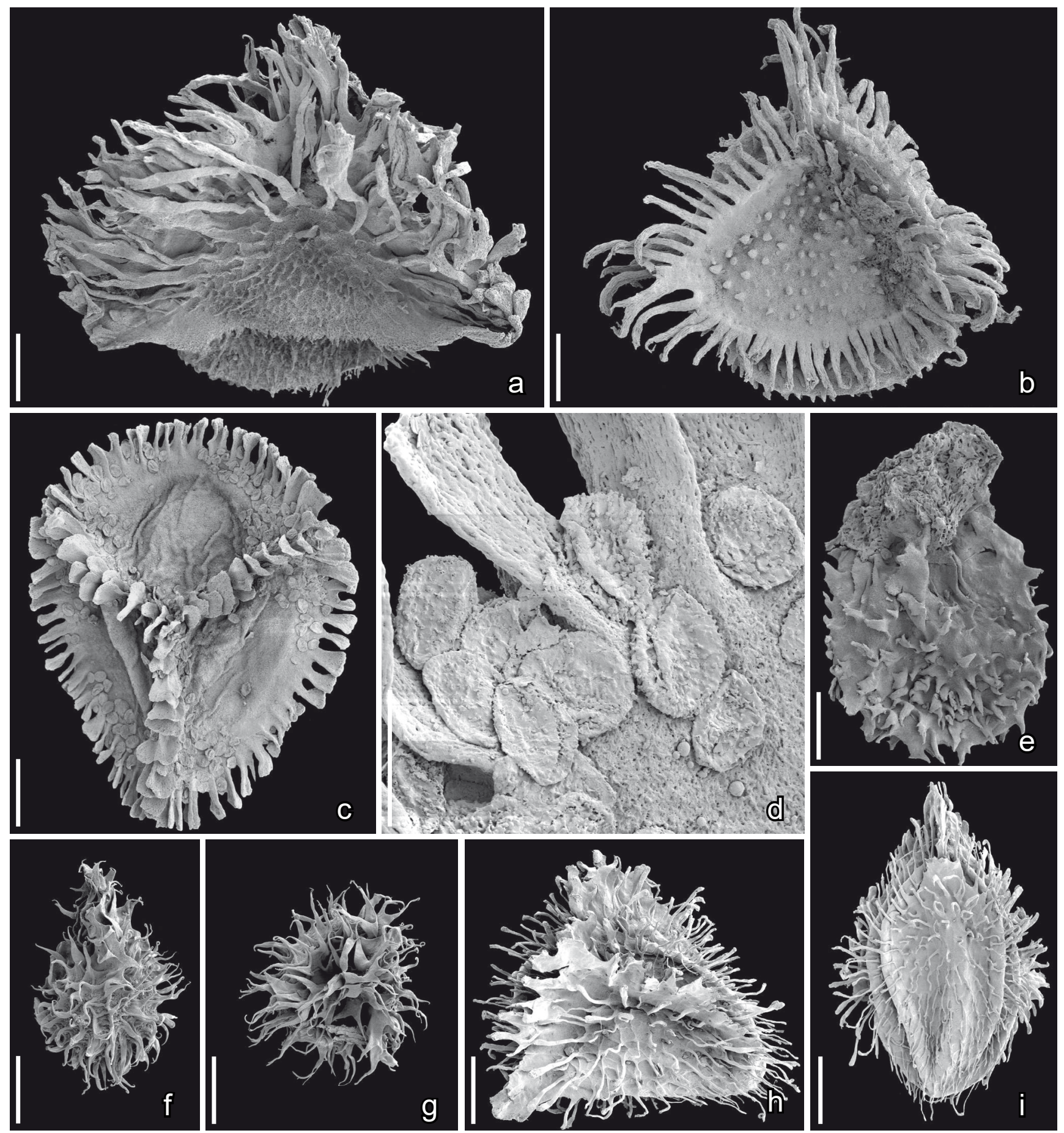

Text-fig. 5. Scanning electron microscope (SEM) images of megaspores with possible affinities to Isoetales (a-d) and megaspores of uncertain affinity (e-i); Torres Vedras locality, Portugal. a) Paxillitriletes reticulatus megaspore in lateral view showing long appendages on the flanges of the laesurae and the reticulate-spiny distal surface; b) Dijkstraisporites sp. megaspore in oblique lateral view showing long, sometimes dichotomizing, appendages on the equatorial flanges and bordering the laesurae; c, d) Tenellisporites sp. megaspore in proximal view (c) showing equatorial flanges and laesurae with short, broad, flattened and unbranched appendages; note numerous, spiny microspores adhering to the proximal face of the megaspore (d); e) Megaspore type sp. 2 in lateral view showing apical gula and ornamentation of scattered spines; $f$, g) Megaspore type sp. 3 in lateral (f) and proximal (g) view showing broad, often dichotomously branched appendages covering the megaspore surface; $h$, i) aff. Flabellisporites sp. megaspores in proximal (h) and lateral (i) view showing long, narrow appendages covering the megaspore surface. Specimens, TV39-S174619 (a), TV38-S170220 (b), TV38-S170221 (c, d), TV44-S174574 (e), TV44-S174575 (f), TV44-S174577 (g), TV38-S170223 (h), TV38-S170222 (i). Scale bars $100 \mu \mathrm{m}$ (a-c, e-i), $25 \mu \mathrm{m}$ (d).

mesofossil floras from Portugal, such as the Famalicão flora, megaspores of Cabochonicus carbunculus are common and well-preserved. The systematic affinity of Cabochonicus carbunculus is unknown.

\section{Megaspore sp. 1 \\ Text-fig. $4 p$}

Description and remarks. Megaspores are trilete and azonate with raised laesurae and densely spaced, 
verrucae that have a pitted-granular surface (Text-fig. $4 p$ ) reflecting the densely arranged fibrous elements that make up the wall.

Affinity and other occurrences. We have not been able to match Megaspore sp. 1 to any known genus or species. In the mesofossil floras from Portugal megaspores of this kind are currently known only from the Torres Vedras flora. The systematic affinity of the species is unknown.

\section{Genus Paxillitriletes J.W.HALl et Nicolson, 1973 emended by Batten and Koppelhus (1993)}

\section{Paxillitriletes reticulatus (MÄDLER) J.W.HALL et Nicolson, 1973 \\ Text-fig. 5a}

Description and remarks. Megaspores are zonate and coronate, with reticulate ornamentation on the distal face. They are characterized by a narrow equatorial flange that generally lacks appendages, and long, flat appendages that border the laesurae (Text-fig. 5a).

Affinity and other occurrences. Megaspores of Paxillitriletes and comparable zonate and coronate megaspores are generally thought to be of isoetalean affinity (e.g. Batten and Koppelhus 1993). The taxonomy of these megaspores is not straightforward and the many different genera that have been established based on fossil material are not always clearly delimited (Batten and Koppelhus 1993). Megaspores assigned to Paxillitriletes reticulatus were first described from the Wealden of Germany as Thomsonia reticulata MäDLER (Mädler 1954) and the megaspores from Torres Vedras are especially similar to Paxillitriletes megaspores described from the earliest Cretaceous (Berriasian) of Bornholm, Denmark (Koppelhus and Batten 1992, Batten and Koppelhus 1993). Among the Portuguese mesofossil floras, Paxillitriletes reticulatus is currently known from the Catefica locality, in addition to Torres Vedras.

Genus Dijkstraisporites R.Potonı́, 1956

emended by Batten and Koppelhus (1993)

\section{Dijkstraisporites sp.} Text-fig. 5b

Description and remarks. Megaspores are zonate, coronate, and characterized by long, narrow, flattened appendages arranged along the equatorial flange and laesurae. The appendages are of various widths and often bifurcate. Both distal and proximal surfaces of the megaspores have an echinate ornamentation (Text-fig. 5b).

Affinity and other occurrences. Megaspores of Dijkstraisporites sp. are similar in general morphology to those of Tenellisporites sp. (see below), but the appendages are longer than is typical for Tenellisporites megaspores. This is also the case for the appendages of the Torres Vedras specimens. The bifurcations and uneven shape of the appendages in the Torres Vedras specimens are similar to those described for Dijkstraisporites, but the length of the appendages is shorter than is typical. In the Early Cretaceous mesofossil floras of Portugal this species is rare. So far, in addition to the specimens from Torres Vedras, only a single specimen has been recovered from the Vale de Água locality. Dijkstraisporites is thought to be of isoetalean affinity.

Genus Tenellisporites R.PоTоNIÉ, 1956

emended by Batten and Koppelhus (1993)

\section{Tenellisporites sp.}

Text-fig. 5c, d

Description and remarks. Megaspores are zonate, coronate, and characterized by short and broad, flattened appendages that are arranged along the equatorial flange and laesurae. Both distal and proximal surfaces are almost smooth (Text-fig. 5c). Microechinate microspores occur abundantly on the proximal surface of some megaspores (Text-fig. 5d).

Affinity and other occurrences. Tenellisporites is common in the Torres Vedras assemblage, but has not been observed in other mesofossil floras from Portugal. Species of Tenellisporites are otherwise common in Cretaceous deposits, including many records from the Late Cretaceous (Koppelhus and Batten 1989, Batten and Kovach 1990). Megaspores of Tenellisporites are thought to be of isoetalean affinity (see also Paxillitriletes).

\section{Genus Flabellisporites MARCINK., 1978}

\section{aff. Flabellisporites sp.}

Text-fig. 5h, i

Description and remarks. Megaspores are azonate, with laesurae that have raised, membranous margins. The megaspore surface beyond the zone around the trilete mark is reticulate, with muri that bear long narrow hair-like appendages with spatulate tips (Text-fig. 5h, i).

Affinity and other occurrences. The botanical affinities of Flabellisporites megaspores may be with Isoetales (Lupia 2004). The genus was established based on megaspores from the Triassic of Poland (Marcinkiewicz 1978). Closely similar megaspores have been described from the Early Cretaceous Potomac Group as aff. Flabellisporites sp. A (Lupia 2004), and from the Barremian of southern England as aff. Flabellisporites sp. (Nye et al. 2008). The stratigraphic range for these kinds of megaspores is thought to be Barremian - Aptian (Lupia 2004). Among Portuguese mesofossil floras the species is currently known only from the Torres Vedras, Catefica and Juncal localities.

\section{Megaspore sp. 2 Text-fig. 5e}

Descriptions and remarks. Megaspores are azonate with a distinct gula and short, flattened appendages scattered over the megaspore body (Text-fig. 5e). The appendages are pointed or bifurcate at the apex.

Affinity and other occurrences. Megaspore sp. 2 closely resembles megaspores figured by Batten (2012) as Echitriletes zemechensis KNOBLOCH from the Cenomanian of the Czech Republic, but differs in its broader appendages. Megaspore sp. 2 also differs from the type species of Echitriletes Hammen ex R.Potonié (E. lanatus (DiJkstra) 
R.Potonié) that lacks the gula and has fine, hair-like projections over the megaspore surface (Dijkstra 1949).

\section{Megaspore sp. 3 \\ Text-fig. 5f, g}

Description and remarks. Megaspores are small, trilete, azonate and covered by long, densely spaced and flattened appendages that are bifurcate distally (Text-fig. $5 f, g)$.

Affinity and other occurrences. Megaspore sp. 3 has a distinctive morphology that we have been unable to match with any previously described taxon. They show some similarity to the megaspores of Arcellites stellatus M.D.NowAK et LuPIA from the Early Cretaceous of Maryland (Nowak and Lupia 2004), but the appendages of the Torres Vedras specimens are bifurcate and more densely distributed. In addition to its occurrence at Torres Vedras Megaspore sp. 3 is also known from the Catefica mesofossil flora.

\section{Class Polypodiopsida Cronquist, TAKHT. et W.ZIмм., 1966}

$\mathrm{R}$ e $\mathrm{m}$ a r k s . Ferns are represented in the Torres Vedras mesofossil by salvinealean megaspores with their associated microspores, as well as vegetative and fertile portions of various other ferns, including tiny fiddleheads, fragments of pinnules and sporangia with microspores. In this section, we briefly describe the megaspores and microspores. The vegetative remains provide evidence of additional fern diversity, but are not especially common and are too fragmentary for more precise systematic determination. Microspores recovered in sporangia or in clumps are probably mostly from ferns, but some may represent other spore-bearing plants such as lycopodiopsids and bryophytes.

\section{Order Salviniales BARTL. in MART., 1835}

Genus Molaspora Schemel, 1950 emended by Hall (1963)

\section{Molaspora sp. \\ Text-fig. 6a, b}

Description and remarks. Megaspores almost spherical, $270-380 \mu \mathrm{m}$ in diameter, with a finely verrucate to papillate surface and an apical acrolamella. Acrolamella up to $110 \mu \mathrm{m}$ tall and $100-120 \mu \mathrm{m}$ wide, consisting of about six straight to slightly twisted lobes (Text-fig. 6a, b).

Affinity and other occurrences. The fossil megaspore genus Molaspora was first described by Schemel (1950) from the mid-Cretaceous of Iowa, USA, and includes about six species that are restricted to Cretaceous strata, except for one species reported from the Palaeogene (e.g. Lupia et al. 2000, Zavialova and Batten 2018). The Torres Vedras fossils are most similar to specimens assigned to the species Molaspora lobata (DIJKSTRA) HaLL, first described as Triletes lobatus DiJkstra (Dijkstra 1949) from the Late Cretaceous of the Netherlands. However, Molaspora lobata typically has a shorter acrolamella than the Torres Vedras specimens, and the megaspore surface is more prominently papillate. The Torres Vedras specimens are therefore referred to Molaspora only at the genus level.
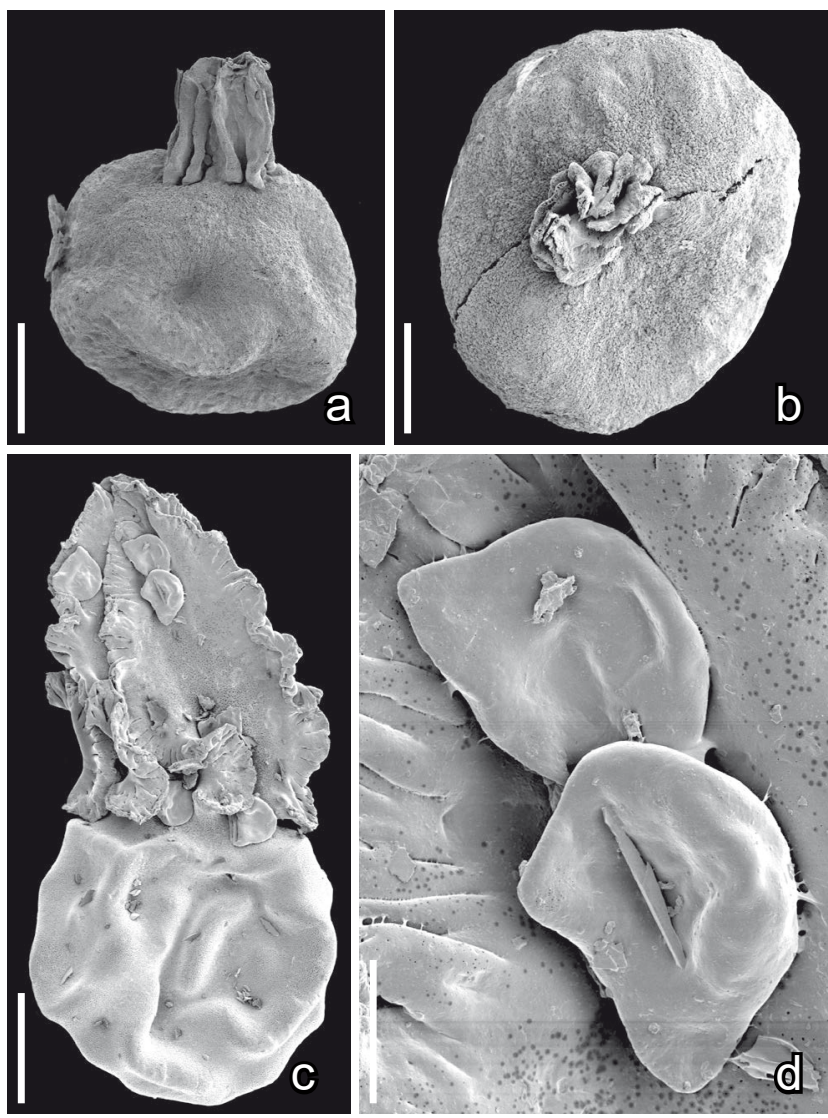

Text-fig. 6. Scanning electron microscope (SEM) images of megaspores $(a-c)$ and attached microspores $(c, d)$ with possible affinities to Salviniales; Torres Vedras locality, Portugal. a) Lateral view of Molaspora sp. megaspore showing almost spherical body with a relatively long apical acrolamella; b) Apical view of Molaspora sp. megaspore showing almost spherical body with slightly twisted apical acrolamella; c, d) Lateral view of Arcellites punctatus megaspore showing coarsely rugulate body and apical acrolamella with attached microspores (d). Specimens, TV39-S174616 (a), TV38-S170224 (b), TV43-S170169 (c, d). Scale bars $100 \mu \mathrm{m}$ (a-c), $25 \mu \mathrm{m}$ (d).

Molaspora has long been compared to megaspores of the extant genus Regnellidium Lindm. (Marsiliaceae, Salviniales) and recent discoveries of Molaspora-type megaspores in situ within sporocarps (Lupia et al. 2000), and also associated with leaves, roots and sporocarps (Cúneo et al. 2013), have confirmed a close relationship between the extinct genus and the extant family.

Molaspora is rare in the Early Cretaceous mesofossil floras from Portugal, and is currently known only from the Torres Vedras, Buarcos and Catefica localities. In the Catefica mesofossil flora a fragment of a Molaspora sporangium contains both megaspores and microspores.

Genus Arcellites Miner, 1935

emended by Ellis and Tschudy (1964)

\section{Arcellites punctatus E.M.FrIIS, K.R.PEDERSEN et Marone, 2014 \\ Text-fig. 6c, d}

Description and remarks. The species is common in the Torres Vedras mesofossil flora from which more than 100 specimens of megaspores, often 

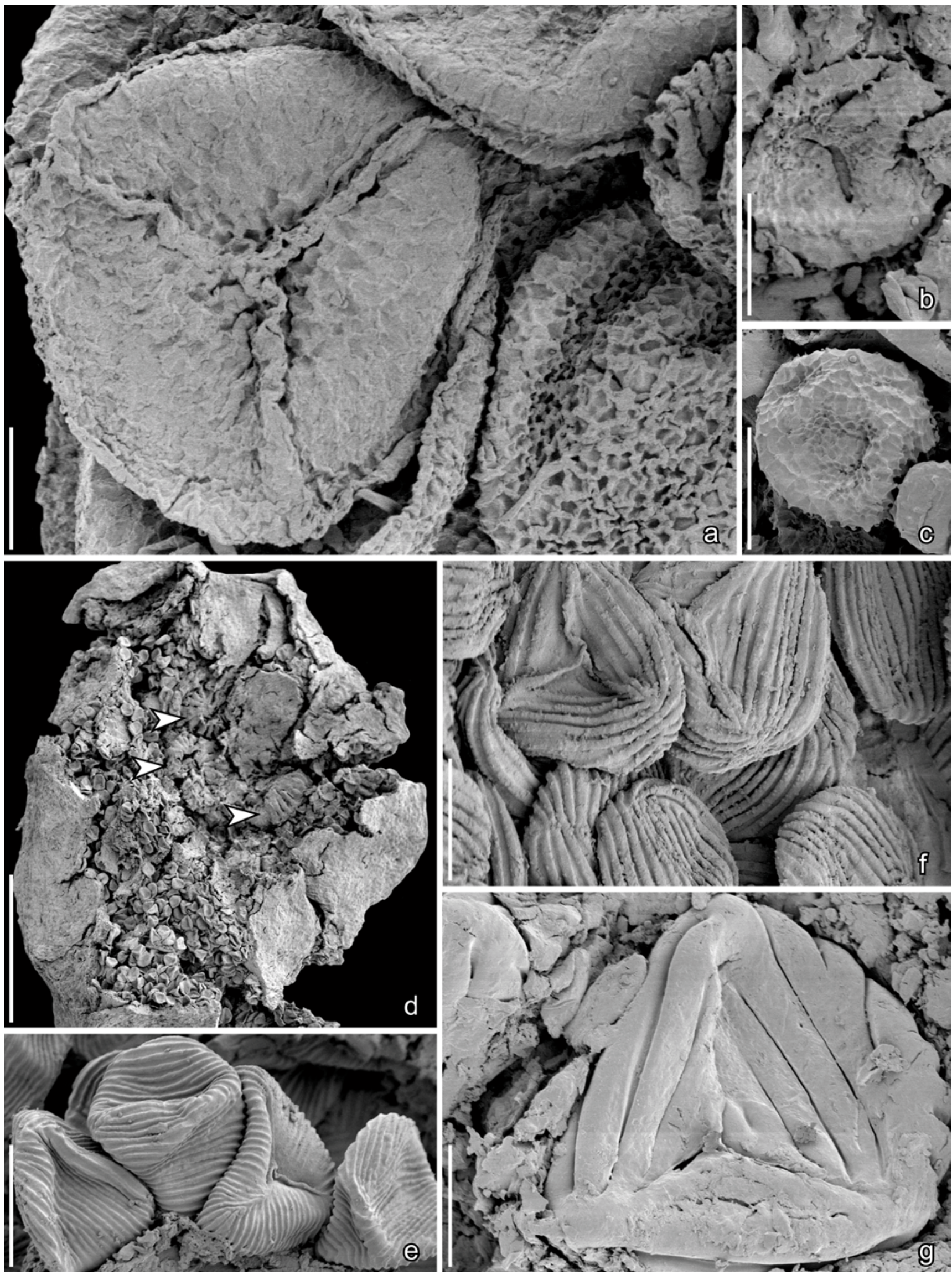

Text-fig. 7. Scanning electron microscope (SEM) images of spores with possible affinities to lycopodiopsids (a-c) and Schizaeaceae (d-g); Torres Vedras locality, Portugal. a) Densoisporites sp. from a clump of spores in proximal (left) and partial distal views (right) showing the narrow equatorial flange, long laesurae, and reticulum that is coarser on the distal surface than on the proximal surface; b, c) Unnamed microspores from clump of microspores in proximal (b) and distal (c) views showing finely reticulate surface; d, e) Cicatricosisporites ventusus fertile pinnules showing numerous attached sporangia (d) each with terminal annulus (arrowheads) and spores in situ (e); f) Cicatricosisporites sp. 1 spores from fertile pinnules bearing sporangia with a terminal 
with associated microspores (Friis et al. 2014b) have been recovered. The megaspores are spherical, lack appendages on the spore wall and have a long, twisted acrolamella often with smooth microspores attached to its surface (Text-fig. 6c, d).

Affinity and other occurrences. Arcellites punctatus is the only species of Arcellites currently recognized in the mesofossil floras from the Early Cretaceous of Portugal. In addition to the specimens from Torres Vedras, other (rare) specimens are known only from Buarcos and Catefica. The presence of an acrolamella, and the associated microspores, clearly indicate a relationship to extant Marsileaceae, with the fossil genus most likely on the stem group of the extant family.

\section{Microspores \\ Text-figs $7 \mathrm{a}-\mathrm{g}, 8 \mathrm{a}-\mathrm{k}$}

R e marks. A palynological investigation of samples from the lower plant bearing horizon at Torres Vedras identified about 48 different kinds of dispersed microspores (Konradsen 1996). The mesofossil flora from the same horizon yielded many fragments of sporangia with spores in situ or in clumps, but the diversity of spores in the mesofossil flora, with only about 12 different species recognized, is much lower than the spore flora recognized in the palynological preparations. A few of the spores, such as Densoisporites sp. and the unnamed spore 1 (Text-fig. 7a-c), were probably produced by lycopodiopsids, while many of the others are thought to have been produced by ferns (Textfigs $7 \mathrm{~d}-\mathrm{g}, 8 \mathrm{a}-\mathrm{c})$. Some of the spores are more difficult to place systematically, and some may have been produced by bryophytes.

Three different kinds of trilete and azonate spores that are ornamented with parallel sets of ridges (cicatricose sculpture) are assigned to the genus Cicatricosisporites R.Potonié et Gelletich and are recorded here as Cicatricosisporites ventusus DEÁK (Text-fig. 7d, e), Cicatricosisporites sp. 1 (Text-fig. 7f) and Cicatricosisporites sp. 2 (Text-fig. $7 \mathrm{~g}$ ). Spores of Cicatricosisporites ventusus DEÁK and Cicatricosisporites sp. 1 occur in sporangia that have a terminal annulus and that are densely crowded on fertile pinnules (Text-fig. 7d), all features very similar to those of extant Schizaeaceae and they were probably produced by ferns closely related to species of the extant schizaeaceous fern Anemia Sw. Spores of Cicatricosisporites sp. 2 were found in a clump without any associated remains of sporangia or fertile pinnules, but are probably closely related to the other Cicatricosporites species and extant Schizaeaceae based on spore morphology. Schizaeaceous spores are very common in Early Cretaceous palynofloras (e.g. Dettmann and Clifford 1992) and have also been recovered commonly associated with meso- or macrofossil remains (e.g. Hernandez-Castillo et al. 2006).

Other common fern spores in the Torres Vedras mesofossil flora include a diversity of trilete and azonate forms with almost psilate surfaces that are commonly assigned to different species of Cyathidites Couper. Two forms are shown here, assigned to Cyathidites minor COUPER (Text-fig. 8a, b) and C. australis COUPER (Text-fig. 8c). These kinds of spores are known to have been produced by several extant families of ferns, including the Cyatheaceae, Gleicheniaceae, Dicksoniaceae and Matoniaceae.

Among the more distinctive spores encountered in the mesofossil flora are spores of Taurocusporites segmentatus STOVER recovered from a spore-mass that apparently comprises several sporangia adhering together in a linear arrangement (Text-fig. 8d-f). The spores are characterized by the partitioning of the distal surface into concentric regions and the presence of distinct segmented laesurae on the proximal surface (Text-fig. 8e, f).

Also in the Torres Vedras mesofossil flora are several isolated spore masses consisting of spores with a foveolate to rugulate distal surface and a granular-verrucate or psilatepunctate proximal surface (Text-fig. $8 \mathrm{~g}-\mathrm{k}$ ). Some of these spores (Text-fig. 8g, i, j) are similar to spores assigned to Patellasporites tavaredensis J.J.Groot et C.R.Groot from the Casal do Borracho palynoflora by Mendes et al. (2018) and other Portuguese palynofloras (e.g. Trincão 1985, Mendes et al. 2014). However, the spores from Torres Vedras do not match completely the description and illustrations of the type material from the Buarcos-Taverede region (Groot and Groot 1962) and we refer to the Torres Vedras spores as Patellasporites cf. tavarendensis. These spores also show some similarities to spores assigned to Cingutriletes R.L.PIERCE that have been compared to spores produced by bryophytes (e.g. Dettmann 1963).

\section{Class Coniferopsida Burnett, 1833}

Remarks. Conifers are represented in the Torres Vedras mesofossil mainly by seeds, twigs, cone scales and clumps of pollen. All twigs and cone scales are very small and are not described here, but appear to include two or three different kinds of shoots with Brachyphyllum type foliage. Apart from a single, poorly preserved twig fragment of Pseudofrenelopsis NATH. vegetative remains or pollen of Cheirolepidiaceae have not been recovered in the mesofossil flora and only rare Classopollis H.D.PFLug pollen grains were encountered in the palynological preparations from the same samples (Konradsen 1996). In this section, we illustrate the two pollen types and the most common seed type recovered in the mesofossil flora. In the palynological preparations Konradsen (1996) identified several different kinds of conifer pollen, including several different kinds of bisaccate pollen.

\section{Genus Araucariacites Cookson, 1947}

\section{Araucariacites sp.} Text-fig. 9

Description and remarks. The material comprises several fragments of pollen sacs, as well as isolated pollen clumps, containing Araucariacites pollen 

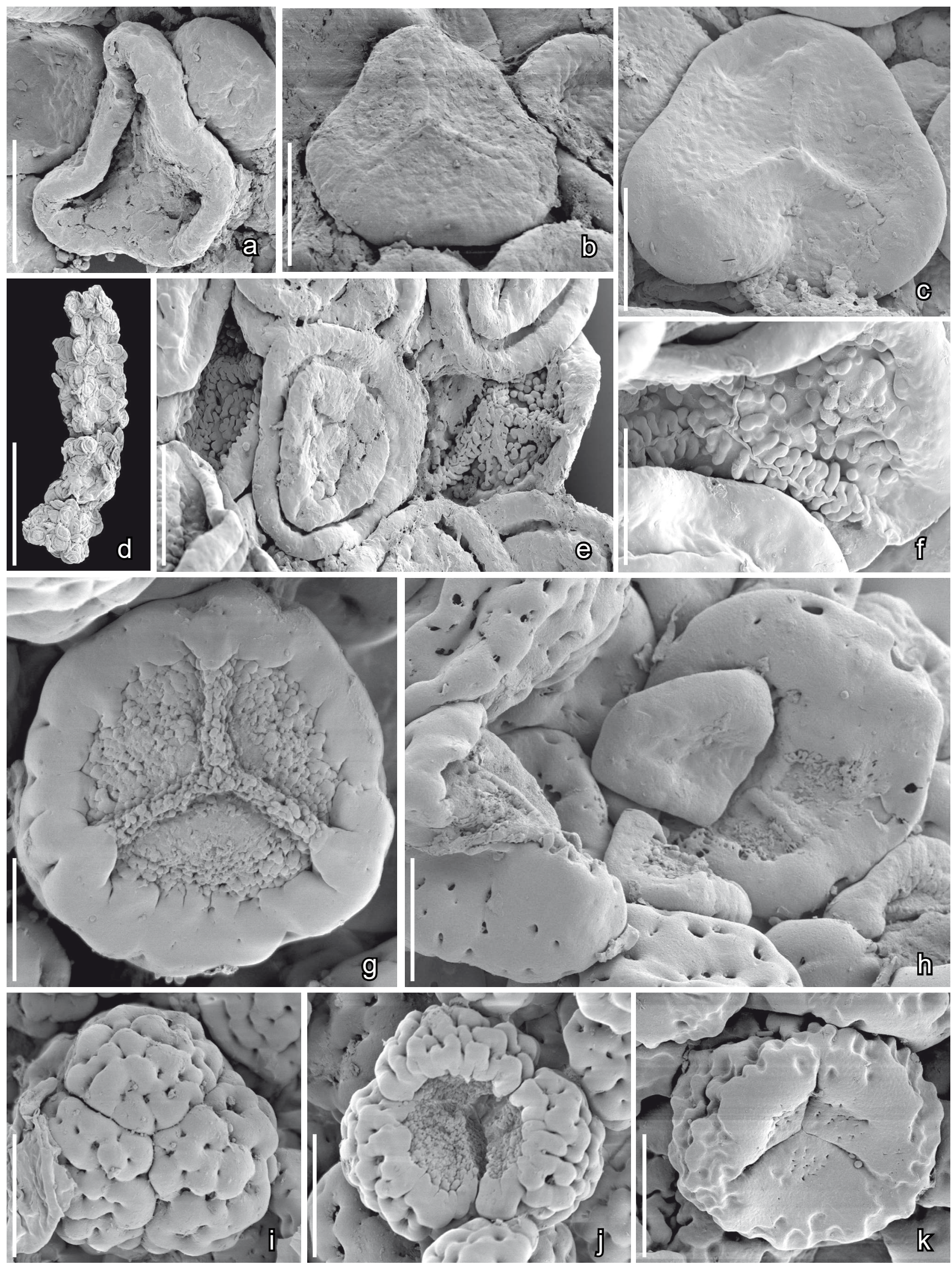

Text-fig. 8. Scanning electron microscope (SEM) images of spores from clumps of spores and sporangia with affinities to polypodiopsids (a-c) and of uncertain affinity (d-k); Torres Vedras locality, Portugal. a) Folded Cyathidites minor spores in proximal view showing trilete mark, from clump of spores; b) Cyathidites minor spores in proximal view showing trilete mark, from group of sporangia; c) Cyathidites australis spores in proximal view showing trilete mark, from group of sporangia; $d-f$ ) Linear group of spore masses (d; probable sporangial contents) composed of Taurocusporites segmentatus spores showing distal surface (e, middle) with concentric regions and proximal surface with segmented laesurae of elongated granules (e, right; $f$ ); 
(Text-fig. 9a, d). Pollen grains are alete, circular in outline, about $65 \mu \mathrm{m}$ in diameter and typically flattened and folded (Text-fig. 9d). The exine surface is finely papillate to microechinate (Text-fig. 9b). Abundant small rounded orbicules cover the inner surface of the pollen sacs and are densely distributed over the surface of the pollen (Textfig. 9d). Orbicules are doughnut-shaped, about $2 \mu \mathrm{m}$ in diameter, with irregular ridges radiating from a small central depression (Text-fig. 9c).

Affinity and other oc currences. Araucariacites was established by Cookson (1947) based on pollen from Cainozoic strata of the Kerguelen Archipelago. The type species, Araucariacites australis CoOKson, has been used very widely for pollen grains from most regions of the world that range in age from Triassic to Neogene (Raine et al. 2011). Cookson (1947) compared pollen of Araucariacites australis with pollen of extant Araucaria Juss. and Agathis SALISB. (Araucariaceae), but no vegetative remains or cones of Araucariaceae have been encountered in any of the Cretaceous mesofossil floras from Portugal and closely similar pollen is also produced by other conifers, for example by extant Cunninghamia lanceolata Hook. (Cupressaceae) (Bykowska and Klimko 2016). However, Araucariacites pollen has been found in situ in an araucarian cone from the Early Cretaceous of Spain (Kvaček et al. 2018).

Araucariacites pollen grains similar to those from Torres Vedras occur at most of the Early Cretaceous mesofossil localities in Portugal that we have studied, and similar pollen assigned to Araucariacites australis is also common in some of the Torres Vedras palynological preparations studied by Konradsen (1996).

\section{Bisaccate pollen \\ Text-fig. 10c}

Description and remarks. Fragments of pollen sacs containing bisaccate pollen grains, and also isolated clumps of bisaccate pollen, are common among the mesofossils from Torres Vedras. The grains have two large distinct sacs, are about $55 \mu \mathrm{m}$ long, and have a finely scabrate surface. Abraded grains show that the sacci have a resistant internal reticulum.

Affinity and other occurrences. The bisaccate pollen grains from Torres Vedras are similar to dispersed grains that have been assigned to genera such as Pinuspollenites RAATz, Cedripites WoOdehouse and Podocarpidites (CoOKSON) R.Potonié that have been reported from many Early Cretaceous floras. There is a general resemblance to pollen of extant Pinaceae, but also to the bisaccate pollen of other groups of extant conifers. Fossil pollen of this kind differs from the bisaccate pollen grains produced by various group of extinct seed plants (e.g. Caytoniales, Umkomasiales) in having larger and more prominent sacci that are partially constricted where they join the central body (corpus) of the grain.

Pollen sacs containing various kinds of bisaccate pollen grains, or pollen clumps composed of bisaccate grains, occur at most of the Early Cretaceous mesofossil localities we have studied from Portugal. Several kinds of bisaccate pollen grains are also present in the palynological preparations from Torres Vedras studied by Konradsen (1996), but are typically not a major component of the pollen assemblages.

\section{Conifer seed \\ Text-fig. 10a, b}

Description and remarks. Seeds are rectangular to broadly elliptical in outline, flattened dorsiventrally, about $2 \mathrm{~mm}$ long and $1.7 \mathrm{~mm}$ wide. They have a pointed apex, a truncate base, and two massive, broad lateral wings that extend on either side of the central seed body (Text-fig. $10 \mathrm{a}, \mathrm{b})$. The seed surface is smooth with a thick cuticle that is often abraded. Epidermal cells are narrowly rectangular and arranged in longitudinal rows. The wall of the central seed body is sclerenchymatic and formed from small isodiametric stone cells.

Affinity and other occurrences. In their general organization, and also the structure of the seed wall, the seeds are similar to those of various groups of extant conifers. However, corresponding seed cones have not been recovered, and the seeds have no distinctive features that permit more precise systematic assessment. Seeds of broadly similar structure are produced by various extant Cupressaceae.

Conifer seeds of this kind are common in the Early Cretaceous mesofossil floras from Portugal and were probably produced by several different kinds of conifers. Similar conifer seeds (conifer seeds sp. 1) were described from the Vale Painho mesofossil flora from Portugal (of possible Berriasian age), but these differ in their ovate rather than broadly elliptical outline (Mendes et al. 2011). Another kind of smaller conifer seed that lacks a wing is also recorded from the mesofossil flora, but is rare (not shown).

\section{Informal grouping Bennettitales-Erdtmanithecales- Gnetales}

\section{Genus Buarcospermum E.M.FriIS, K.R.PEDERSEN et P.R.Crane, 2009}

\section{Buarcospermum tetragonium E.M.FriIS, K.R.PEDERSEN et P.R.Crane, 2009}

Description and remarks. From the Torres Vedras locality Buarcospermum tetragonium is known only

g) Patellasporites cf. tavaredensis spore in proximal view showing finely granular surface between laesurae, from a clump of spores; h) Patellasporites cf. tavaredensis spores showing irregular shape and size with finely granular surface between laesurae and perforate spore wall on distal side, from a clump of spores; i, j) Patellasporites cf. tavaredensis spores showing a tetrad with four spores adhering (i) and a tetrad where one spore is detached (j), from a clump of spores; note perforate distal surface and finely granular proximal surface; k) Patellasporites cf. tavaredensis spores showing tetrad where one spore is detached exposing the finely punctate proximal spore wall, from a clump of spores. Specimens, TV44-S174555 (a), TV44-S174567 (b), TV44-S174564 (c), TV44-S148022 (d-f), TV43-S148211 (g, i, j), TV44-S174563 (h), TV43-S174556 (k). Scale bars $300 \mu \mathrm{m}$ (d), $20 \mu \mathrm{m}$ (a-c, e-k). 

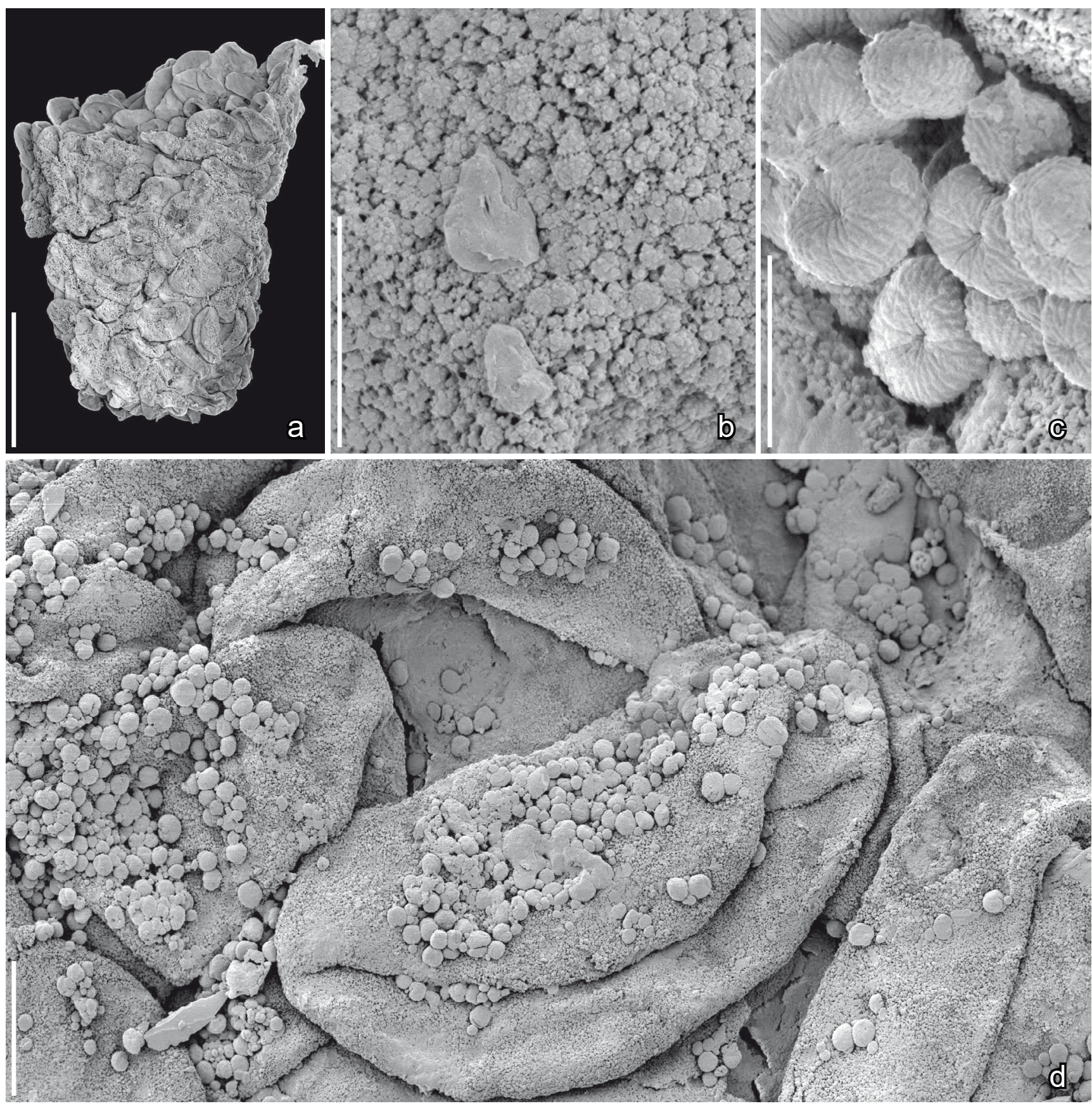

Text-fig. 9. Scanning electron microscope (SEM) images of inaperturate Araucariacites sp. pollen from two fragmentary pollen sacs; Torres Vedras locality, Portugal. a) Fragmentary pollen sac; b) Granular inner surface of pollen sac (a); c) Orbicule showing finely striate surface; d) Group of pollen grains from pollen sac in (a) showing granular exine surface and numerous orbicules; note that the scale bar $(12 \mu \mathrm{m})$ is two times larger than that used for most other pollen grains illustrated in this paper $(6 \mu \mathrm{m})$. Specimens, TV44-S148025 (a, b, d), TV44-S148146 (c). Scale bars $150 \mu \mathrm{m}$ (a), $12 \mu \mathrm{m}$ (d), $3 \mu \mathrm{m}$ (b, c).

from a single, small fragment of a chlamydospermous seed in which the seed envelope is formed by fibers arranged in a distinctive chevron-shaped pattern (not shown).

Affinity and other occurrences. Buarcospermum tetragonium was described based on numerous well-preserved specimens from the Buarcos locality, which is the type locality for the genus and species. Buarcospermum tetragonium is also known from the Catefica locality in Portugal, as well as the Puddledock locality in Virginia, USA (Friis et al. 2009).
Genus Ephedrispermum RYdin, K.R.PEDERSEN, P.R.Crane et E.M.FriIs, 2006

\section{Ephedrispermum lusitanicum Rydin, K.R.PEDERSEN,} P.R.Crane et E.M.Friss, 2006

Text-fig. 11d-f

Description and remarks. Chlamydospermous seeds that are four-angled to circular in transverse section, about $0.7 \mathrm{~mm}$ long and $0.55-0.6 .5 \mathrm{~mm}$ wide. The seed envelope is sclerenchymatic with about 40 slightly raised longitudinal ridges (Text-fig. 11d). Ephedroid pollen 
grains have been observed in the micropyles of several specimens and also on the surface of the seed envelope (Text-fig. 11e, f).

Affinity and other occurrences. Ephedrispermum lusitanicum is common in the Torres Vedras mesofossil flora and also in the mesofossil flora from Buarcos (the type locality for the genus and species). Seeds of Ephedrispermum are also known from the Famalicão and Vale de Água mesofossil floras, but these seeds differ in having fewer ridges on the seed envelope and in details of the associated pollen grains. The Famalicão and Vale de Água specimens have been assigned to a separate species $E$. tenuicostatum E.M.FriIs, P.R.CRANE et K.R.PEDERSEN (Friis et al. 2019c).

\section{Genus Quadrispermum E.M.Fris, K.R.PEDERSEN} et P.R.Crane, 2013

\section{Quadrispermum parvum E.M.FriIS, K.R.PEDERSEN et P.R.Crane, 2013 \\ Text-fig. 11b, c, g}

Des cription and remarks. Chlamydospermous seeds that are four-angled to circular in transverse section, about $1.1 \mathrm{~mm}$ long and $0.6 \mathrm{~mm}$ wide. The seed envelope is sclerenchymatic with irregular transverse ridges extending between the corners of the seed envelope (Text-fig. 11b, c). The seed envelope is extended into a pointed micropylar protrusion that is surrounded by a shallow depression (Text-fig. 11b, c, g). No pollen grains have been observed in the micropyle, but monocolpate pollen grains have been observed in the micropylar region of one seed (Text-fig. $11 \mathrm{~g}-\mathrm{i}$ ) and on the surface of two other seeds. The pollen grains are about $13 \mu \mathrm{m}$ long, with a long colpus that extends for almost the full length of the grains. The tectum has a distinctive surface ornamentation formed by a delicate pattern of fine, interwoven elements.
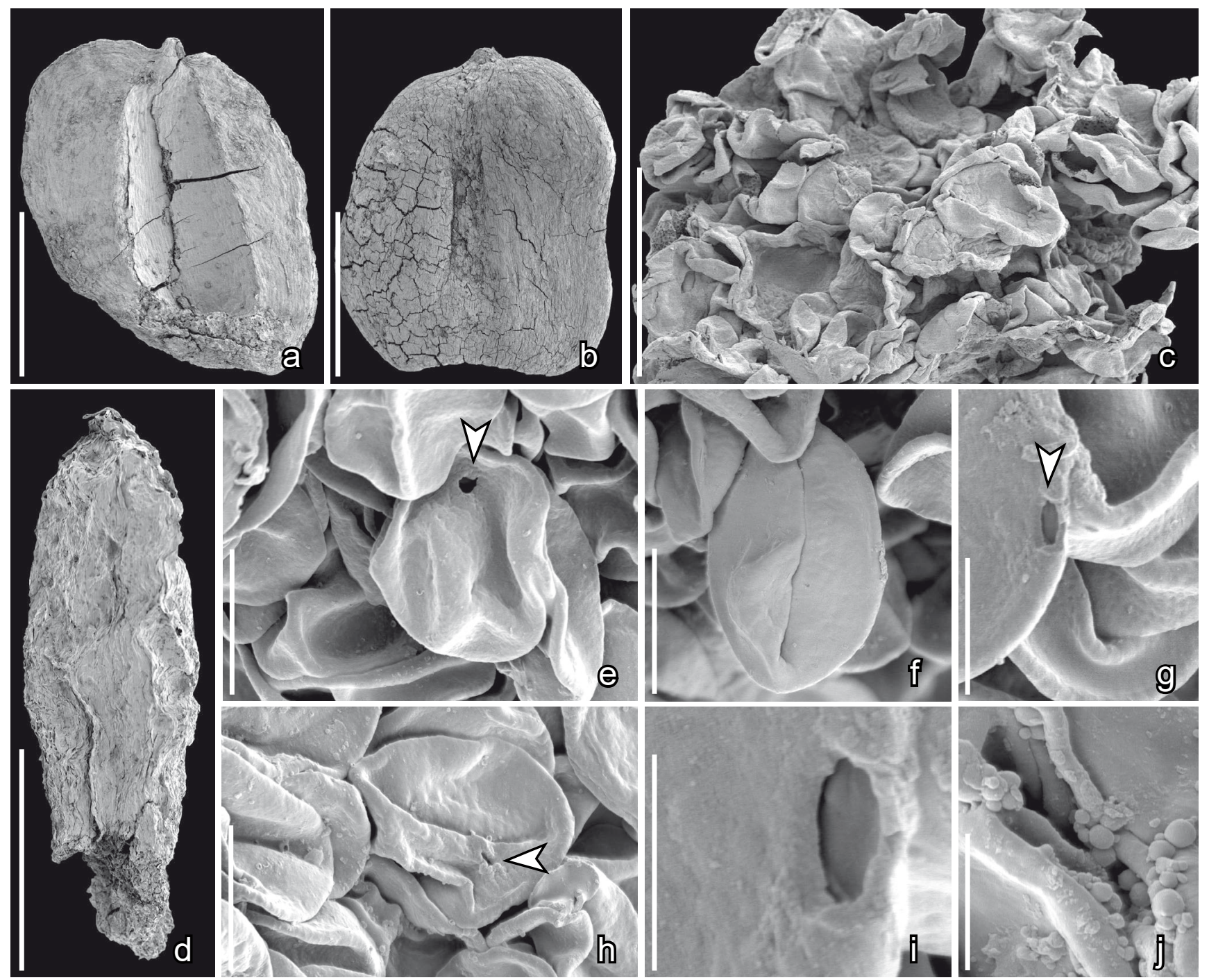

Text-fig. 10. Scanning electron microscope (SEM) images of conifer seeds (a, b) and pollen (c) and monoporate pollen of unknown affinity (d-j); Torres Vedras locality, Portugal. a, b) Unnamed conifer seeds (conifer seed sp. 1); c) Clump of bisaccate pollen grains; d) Fragment with microsporangia that yielded the pollen in (e-j); e, f, h) Monoporate pollen grains folded in various ways, exposing the tiny pore (e, $h$, arrowheads) or resembling a monocolpate grain (f); g) Detail of pollen grain showing pore (arrowhead) and finely rugulate exine surface that reflects the reticulate infratectal layer beneath the thin tectum; i) Detail of pore showing very slightly thickened margin; j) Spherical orbicules on the surface of two grains. Specimens, TV44-S174594 (a), TV44-S174595 (b), TV44-S174573 (c), TV44-S137904 (d-j). Scale bars 1 mm (a, b), $300 \mu \mathrm{m}$ (d), $100 \mu \mathrm{m}$ (c), $6 \mu \mathrm{m}$ (e, f, h), $3 \mu \mathrm{m}$ (g, j), $1.5 \mu \mathrm{m}$ (i). 

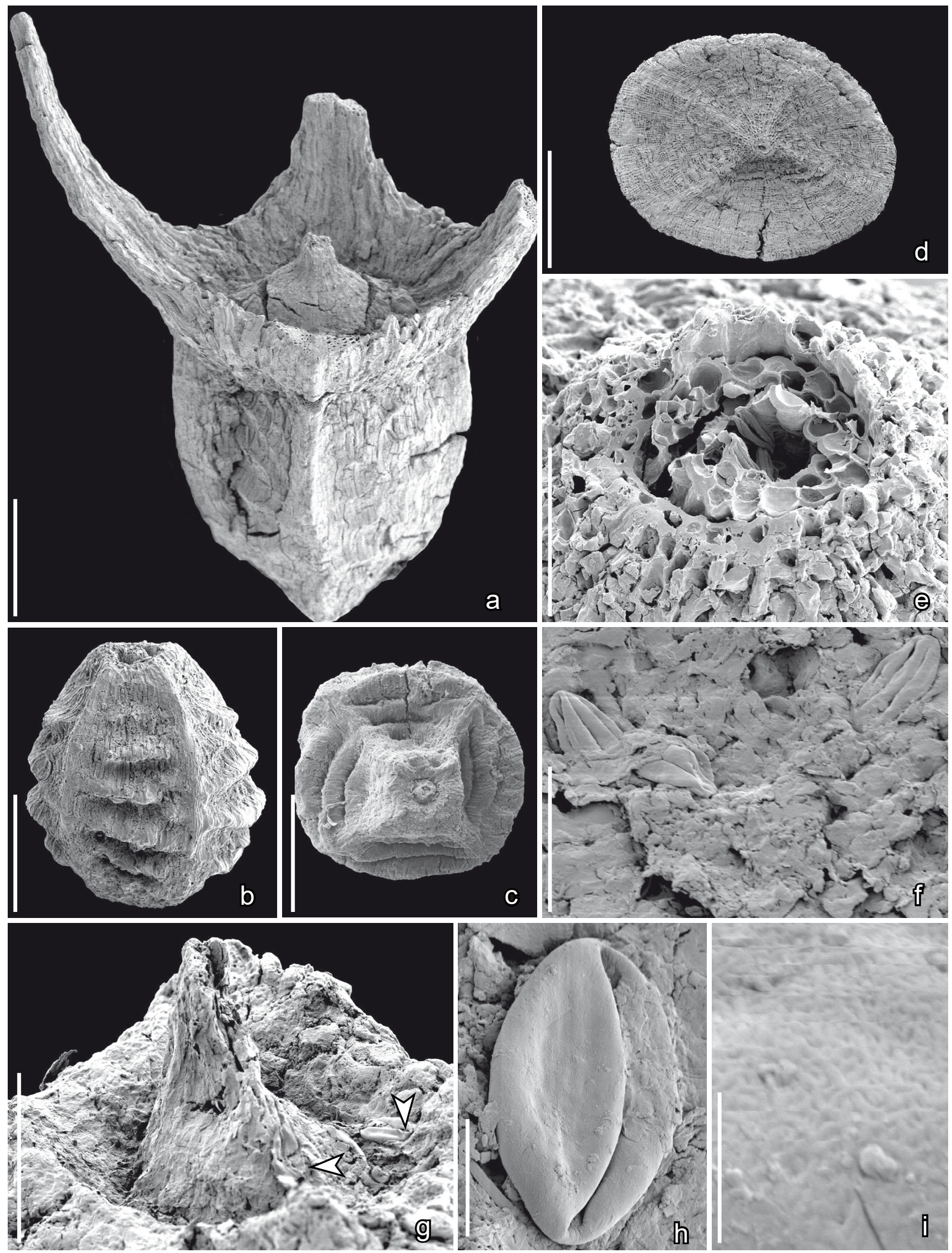

Text-fig. 11. Scanning electron microscope (SEM) images of seeds assigned to the BEG group (a-d) and associated pollen grains (e-i); Torres Vedras locality, Portugal. a) Seed of Tomcatia taylorii showing the four horns formed by extensions of the envelope and the central projection of the envelope that surrounds to the micropylar tube; $b$, c) Seeds of Quadrispermum parvum in lateral (b) and apical (c) views showing the transverse ribs and the central projection of the envelope that surrounds the micropylar tube; $d-f$ ) Seeds of Ephedrispermum lusitanicum showing the four-angled seed envelope (d), the micropylar tube surrounded by the tissues of the integument (e), and ephedroid pollen grains on the seed surface (f); g) Apex of seed of Quadrispermum parvum showing simple 
Affinity and other occurrences. Quadrispermum parvum is common in the Torres Vedras mesofossil flora, and is also recorded from the Arazede, Catefica, Famalicão, and Vale de Água localities in Portugal. The species is also common in the Puddledock mesofossil flora from Virginia, USA (Friis et al. 2013). The distinctive chlamydospermous structure of the seeds indicates a relationship to the Bennettitales-Ertmanithecales-Gnetales group of Friis et al. (2009).

The pollen associated with Quadrispermum has not been linked to other plants in the mesofossil floras from Portugal. It is currently the only pollen type associated with Quadrispermum and it is therefore possible that these grains were produced by the Quadrispermum-plant. The pollen grains are similar to those figured by Hughes and McDougall (1994) as "Small Berriasian monosulcate, with apparently fibrous sexine" from the Worbarrow borehole, Dorset, England, from sediments now dated as of Hauterivian age (Hughes 1994). Among extant plants somewhat similar pollen is known for Ginkgo biloba L., but pollen grains of Ginkgo are much larger (about 30-48 $\mu \mathrm{m}$ long; Korszun and Klimko 2014) than the grains found on the Quadrispermum seeds. A similar interwoven tectum ornamentation is also known for grains found in situ in the Jurassic presumed cycadaceous pollen cone Androstrobus szei T.M.HARRIS (Hill 1990), but these grains are also much larger than those from Torres Vedras.

\section{Genus Tomcatia E.M.FriIs, K.R.Pedersen et P.R.Crane, 2013}

\section{Tomcatia taylorii E.M.FrIIS, K.R.PEDERSEN et P.R.Crane, 2013 \\ Text-fig. 11a}

Description and remarks. Chlamydospermous seeds that are four-angled to circular in transverse section, about $0.9 \mathrm{~mm}$ long without apical projections, about $1.7 \mathrm{~mm}$ long including the projections, and about $0.9 \mathrm{~mm}$ wide. The seed envelope is sclerenchymatic with indistinct and irregular transverse ridges extending between the corners of the seed (Text-fig. 11a). Apically the four corners of the seed envelope are each extended into a long spine and there is a prominent, pointed central protrusion that surrounds the micropyle (Text-fig. 11a).

Affinity and other occurrences. Torres Vedras is the type locality for the genus Tomcatia, of which Tomcatia taylorii is the type species. In the Torres Vedras mesofossil flora T. taylorii is known from numerous wellpreserved specimens. Tomcatia taylorii is also reported from two other Portuguese localities, Buarcos and Catefica. Seeds assignable to Tomcatia (Tomcatia sp.) are also present, but rare, in the Puddledock mesofossil flora from Virginia, USA (Friis et al. 2013).

\section{Spermatophyta, incertae sedis \\ Informal grouping Bennettitales-Erdtmanithecales- Gnetales?}

\section{Monoporate-psilate pollen}

Text-fig. $10 \mathrm{~d}-\mathrm{j}$

Description and remarks. A microsporangiate structure, about $0.7 \mathrm{~mm}$ long and $0.25 \mathrm{~mm}$ wide, with several elongate microsporangia and small monoporate pollen in situ. The microsporangiate structure has a woody appearance (Text-fig. 10d). The pollen grains are small, monoporate and spherical, about $8 \mu \mathrm{m}$ in diameter. The pollen wall is thin and the grains usually folded (Text-fig. 10e-h). The folding sometimes gives the grains the appearance of being monocolpate (Text-fig. 10f), but in other grains a distinct pore is exposed (Text-fig. 10e, g, j). The pore is circular to elliptical in outline, about $0.8 \mu \mathrm{m}$ in diameter, with only a slightly thickened margin (Text-fig. 10i). The surface of the pollen grains is psilate, sometimes with a slightly reticulategrooved appearance reflecting the presence of a reticulate infratectal layer immediately beneath a very thin tectum (Text-fig. 10g). Spherical orbicules of different sizes, 0.02$0.05 \mu \mathrm{m}$ in diameter, occur on the surfaces of many grains (Text-fig. 10j).

Affinity and other occurrences. Pollen of this species has not been observed so far in any other mesofossil flora from Portugal. Spherical, monocolpate and psilate pollen of comparable morphology was reported by Konradsen (1996) in the dispersed palynological assemblages from Torres Vedras, and also from Catefica, and was assigned to Exesipollenites tumulus BALME. However, the in situ grains differ from the dispersed grains from Portugal, and also from the Early Jurassic type specimens of Exesipollenites tumulus from Western Australia, in their much smaller size.

Pollen grains resembling the Torres Vedras pollen and Exesipollenites were found in situ in Williamsoniella lignieri (Nath.) H.H.Thomas (Harris 1974), a bisexual, flower-like bennettitalean reproductive structure, but like the grains of Exesipollenites the grains of Williamsoniella lignieri are much larger than those described here. Interestingly, however, Harris (1974) reported that in well-developed grains "a fine network of ridges enclosing pits" is visible, which is closely similar to reticulate infratectal layer imprinted in the tectum of the Portuguese pollen. It is therefore possible that the Portuguse monoporate grains may have been produced by an Early Cretaceous bennettialean plant with much smaller pollen than the Jurassic Williamsoniella H.H.Tномаs.

Among extant plants monoporate pollen grains are known for some taxodiaceous conifers, but none of them have a pollen wall comparable to the fossil pollen described here. Monoporate pollen is also characteristic of Poaceae (grasses) and related families of monocotyledons, but pollen grains of

monocolpate boat-shaped pollen grains on the surface of the envelope (arrowheads); similar grains were found on two other seeds of Quadrispermum parvum; h, i) Monocolpate pollen grains from the surface of a seed of Quadrispermum parvum showing the long colpus (h) and the finely rugulate exine (i). Specimens, TV43-S154563 (a, c), TV43-S172650 (b), TV43-172601 (d), TV43-S100767 (e), TV43-S154562 (f), TV44-S172575 (g), TV44-S172574 (h-i). Scale bars $300 \mu \mathrm{m}$ (a-d), $50 \mu \mathrm{m}$ (e, g), $20 \mu \mathrm{m}$ (f), $6 \mu \mathrm{m}$ (h), $1 \mu \mathrm{m}$ (i). 
these extant taxa typically have a distinctly microechinate pollen wall and a differentiated apertural region with an annulus and operculum (e.g. Skvarla et al. 2003). We are not aware of any angiosperm pollen with a reticulate infratectal layer similar to that of the Torres Vedras grains.

\section{Genus Sergipea Regali, Uesugui et A.S.Santos, 1974}

Sergipea sp.

Text-fig. $12 \mathrm{a}-\mathrm{d}$
Description and remarks. The specimen comprises a cluster of pollen grains, apparently borne in several spherical sporangia (Text-fig. 12a). The pollen grains are irregular elliptical in outline, about $20 \mu \mathrm{m}$ long, $12.5 \mu \mathrm{m}$ broad, and inaperturate. Each grain shows three sectors separated by rims of thickened and psilate exine with two narrower (proximal?) sectors and one broader (distal?) sector. The two narrower sectors have pointed ends (Text-fig. $12 \mathrm{~b})$, while the brader sector has more rounded ends (Textfig. 12d). All three sectors between the psilate exine rims are
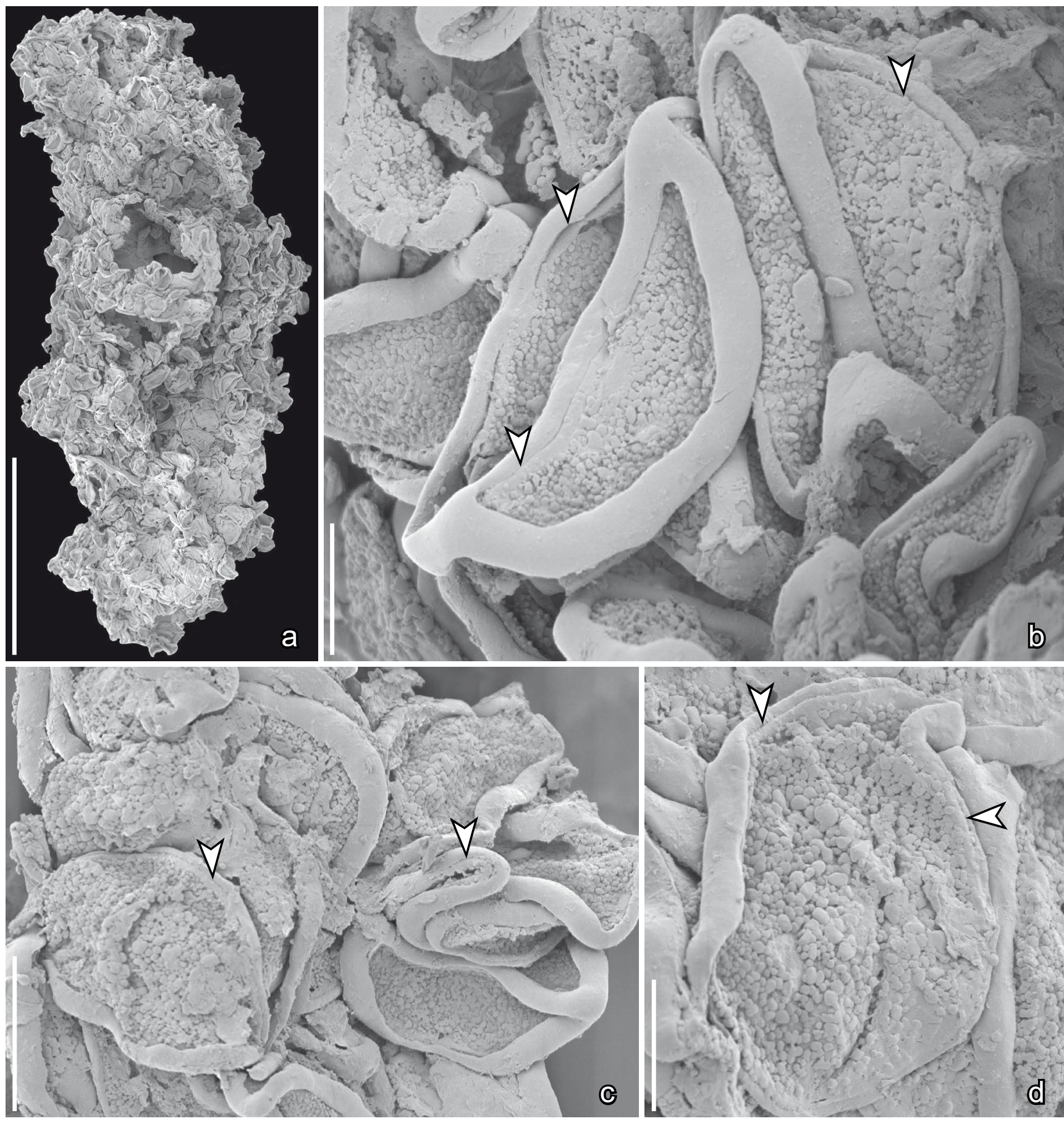

Text-fig. 12. Scanning electron microscope (SEM) images of pollen of Sergipea sp. from a group of probable fragmentary pollen sacs; Torres Vedras locality, Portugal. a) Cluster of probable fragmentary pollen sacs that yielded the pollen in this Text-figure; b, c) Pollen grains showing the robust longitudinal ribs separated by prominent areas of granular exine; note the groove along the margins of the longitudinal ribs (arrowheads); d) Pollen grain showing the granular exine flanked by two robust ribs; note the groove along the margins of the longitudinal ribs (arrowheads). Specimen, TV44-S148012 (a-d). Scale bars $150 \mu \mathrm{m}$ (a), $12 \mu \mathrm{m}$ (c), $6 \mu \mathrm{m}$ (b, d). 
covered by irregular verrucate sculptural elements (Text-fig. $12 \mathrm{~b}-\mathrm{d})$. A fine groove extending close to the margin of the exine rim is seen on both sides of the grains. The function of this groove is uncertain.

Affinity and other occurrences. Sergipea pollen grains are closely similar to certain pollen taxa that are included in the Early to mid-Cretaceous, mainly low palaeolatitude, elater-bearing complex (e.g. Galeacornea Stover). Pollen grains of the elater-bearing complex are generally thought to be related to the Gnetales (Dino et al. 1999). Neumann et al. (2003) also placed species of Sergipea in the Gnetales. While a relationship of Sergipea to extant Gnetales, or to the BEG complex more broadly, seems probable, more detailed comparisons and studies of Sergipea pollen are needed for the secure systematic placement of this unusual pollen type.

The presence of Sergipea at Torres Vedras is the first and only record of the genus from Portugal. It was previously reported in Europe from the stratotype of the Barremian at Angles, southern France, where it occurs in the middle part of the late Barremian section (Renéville and Raynaud 1981). The genus has also been recorded from a single Early Cretaceous palynological assemblage of early Albian age from the USA (Albian Glenrose Formation, Texas, Tanrikulu et al. 2018). Otherwise, Sergipea has only been reported from Early Cretaceous strata in the Southern Hemisphere, where several species have been recorded from Aptian and Albian strata, particularly from Brazil (Regali et al. 1974, Neumann et al. 2003).

\section{Non-angiosperm plant of unknown affinity Text-fig. 13a-f}

Description and remarks. These grains are known from a single clump of pollen or spores (Text-fig. 13a) within which the grains are sometimes separated (Textfig. 13f), but are often attached together in pairs (dyads), threes (triads) or fours (tetrads) (Text-fig. 13b-e). The grains are united by an outer layer of smooth tissue that forms a band-like structure, perhaps partially resistant calloselike remains of the spore mother cell. This smooth tissue extends all the way around a group of grains covering their proximal surfaces (Text-fig. 13b-e). The individual grains are semispherical with a rounded distal face and a flattened proximal face. One isolated grain that shows the proximal face appears to have a trilete mark with laesurae that extend for about two- thirds of the radius of the grains (Textfig. 13f). There is no distal aperture. The wall of the grains is finely granular and perforate (Text-fig. 13c). High resolution SRXTM of the grains shows a thick wall, except on the proximal side where it is thin. The surface of the grains, and the spaces between the grains, have abundant and densely spaced, spherical orbicules of various sizes (Textfig. 13a-f).

Affinity and other occurrences. At a first glance, these grains resemble disaccate pollen with the central body of the grain covered by the bandlike tissue while the sacci are fully exposed. However, SRXTM clearly shows that each coherent group consists of individual grains without an endoreticulum, as in bisaccate pollen. These unusual grains bear some resemblance to the dyads of Dicheiropollis etruscus L.Trevis., a probable cheirolepideaceous conifer that is characteristic of vegetation in the equatorial Dicheiropollis etruscus/ Afropollis palynofloral province region in the Berriassian Aptian. However, in Dicheiropollis etruscus the grains are connected proximally by fine threads.

Subdivisio Angiospermae LindLey, 1830

Nymphaeales SAlisb. ex Bercht. et J.Presl, 1820 -

Austrobaileyales Tакнт. ex Reveal, 1992

Genus Gastonispermum E.M.Fris, P.R.Crane et K.R.Pedersen, 2018

\section{Gastonispermum antiquum E.M.FriIs, P.R.Crane et K.R.Pedersen sp. nov. Text-fig. 14a-e}

H o l o ty p e. Designated here. S136736 (Torres Vedras sample 43; figured Text-fig. 14b).

Plant Fossil Names Registry Number. PFN000453 (for new species).

Paratypes. Designated here. S136737, S136738, S170085 (Torres Vedras sample 43); S136680, S136681, S174629 (Torres Vedras sample 298).

Rep o s i tory. Palaeobotanical Collections, Department of Palaeobiology, the Swedish Museum of Natural History, Stockholm, Sweden.

Etymology. From Latin: antiquus referring to the great age of these seeds.

Type locality. Torres Vedras (NE of Forte de Forca; 39 $06^{\prime} 13^{\prime \prime} \mathrm{N}, 9^{\circ} 14^{\prime} 47^{\prime \prime} \mathrm{W}$ ).

Type stratum and age. Lower member of the Almargem Formation; Early Cretaceous (late Barremianearly Aptian).

Specific diagnosis. Isolated seeds occurring singly. Seeds small, anatropous, bitegmic and exotestal. Seed surface smooth without longitudinal ridges. Course of raphe seen as a slightly raised rounded ridge. Hilum and micropyle separated by a narrow zone of sclerenchyma. Hilar scar small, slightly raised without a hilar rim. Micropyle formed by the inner integument (tegmen) and marked on the seed surface by a Y-shaped slit through the outer integument (testa) adjacent to the hilar scar. Exotesta of palisade-shaped sclerenchyma cells; mesotesta/endotesta of thin-walled parenchyma cells. Palisade-shaped cells of exotesta with evenly thickened anticlinal walls and a straight lumen. Anticlinal walls of palisade-shaped sclerenchyma strongly undulate toward the inside and toward the outside, resulting in stellate-undulate facets and a jigsaw puzzle-like pattern on the seed surface. Tegmen thin.

Distinguishing features. Gastonispermum antiquum is distinguished from Gastonispermum portugallicum E.M.FriIs, P.R.CRANE et K.R.PEDERSEN described from the Famalicão locality (Friis et al. 2018b) by its smaller size, the circular rather than elliptical shape and the thinner seed coat. 
D i m e n s i o n s . Length of seed: $0.9-1 \mathrm{~mm}$; width of seeds: $0.85-1 \mathrm{~mm}$.

Description and remarks. The species is based on five isolated seeds, one of which (S174629) was studied using SRXTM. The seeds are small, anatropous, bitegmic and exotestal (Text-fig. 14a-e). They are almost spherical with a smooth, dull surface. On the surface the slightly raised anticlinal walls of the exotestal cells form a faint jigsaw-puzzle-shaped pattern (Text-fig. 14d).

As in Gastonispermum portugallicum the micropyle and hilum are positioned close together and slightly displaced towards the raphal side (Text-fig. 14b, c, e). The hilum is small and circular, and the micropylar opening is seen externally as a small Y-shaped slit in the exotesta (Text-fig. 14c). The course of the raphe is not distinct on the outside of the seeds. The seed coat consists of a thick exotesta of tall palisade-shaped cells with undulate anticlinal walls, a thin mesotesta/endotesta and a crushed tegmen (Text-fig. $14 \mathrm{e})$. Exotestal cells are about $60 \mu \mathrm{m}$ tall over most of the seed, but this exotestal layer is thicker over the raphe (about $80 \mu \mathrm{m}$ ) and thinner towards the hilum and micropyle (Textfig. $14 \mathrm{e}$ ). Nutritive tissue is not preserved in the specimen studied using SRXTM.

Two specimens (S136748, S136749) in which the fruit wall is partly preserved (Text-fig. 14f, g) provide information on the probable fruits of Gastonispermum antiquum. The fruits are thin-walled and each contains a single exotestal seed. In both cases, the seeds are comparable in size, shape and the jigsaw-puzzle-shaped pattern on the seed surface to the isolated seeds of Gastonispermum antiquum (Textfig. 14h). However, the seed cuticle appears thinner than in the isolated seeds and critical comparison is not possible because features of the micropylar-hilar region are covered by the fruit wall.

Affinity and other occurrences. Seed characters of Gastonispermum strongly suggest a relationship to extant Nymphaeales and Austrobaileyales, but the fossils cannot be placed in any of the extant taxa (Friis et al. 2018b). Gastonispermum antiquum is recorded only from the Torres Vedras locality. The type species of the genus, Gastonispermum portugallicum E.M.FrIIs, P.R.Crane et K.R.Pedersen, is from the Famalicão locality and is also recorded from the Vale de Água locality.

\section{Genus Pazliopsis E.M.FriIs, P.R.Crane et K.R.Pedersen, 2018 \\ Pazliopsis reyi E.M.Fris, P.R.Crane et K.R.Pedersen, 2018 \\ Text-fig. $15 \mathrm{a}-\mathrm{c}$}

Description and remarks. Fruits or fruitlets containing a single anatropous and exotestal seed. Anticlinal cell walls of the exotesta sclerenchyma cells sinuous, forming a jigsaw puzzle pattern on the seed surface (Text-fig. 15a-c). Faint longitudinal ridges on the seed surface distinguish Pazliopsis from most other exotestal seeds that are currently known from the Early Cretaceous. The preservation of Pazliopsis seeds is occasionally excellent with some seeds showing a tiny embryo with two rudimentary cotyledons.
Affinity and other occurrences. Based on comparisons with extant taxa the combined evidence suggests that Pazliopsis reyi is related to extant angiosperms at the level of the ANA grade angiosperms (Amborellaceae, Nymphaeales, Austrobaileyales), but that it cannot be placed securely in any extant family (Friis et al. 2018b). Currently Pazliopsis reyi is recorded only from the Torres Vedras mesofossil floras. Related species, perhaps belonging to the same genus, occur in the Catefica and Famalicão mesofossil floras, but these seeds await detailed description.

\section{Genus Anaspermum E.M.Fris, P.R.Crane et K.R.Pedersen gen. nov.}

Type. Designated here, Anaspermum operculatum E.M.Fris, P.R.Crane et K.R.Pedersen gen. et sp. nov.

Plant Fossil Names Registry Number. PFN000454 (for new genus).

E ty m o logy. From the similarity to seeds of extant ANA grade angiosperms (Amborellaceae, Nymphaeales, Austrobaileyales).

Diagnos is. Seeds small, anatropous, apparently bitegmic and exotestal, occurring isolated and singly. Seeds bilaterally symmetrical with a dorsiventral plane of symmetry. Seed surface smooth without longitudinal ridges. Course of raphe seen on the surface of the seed as a slightly raised ridge. Micropyle and hilar scar closely spaced on a small cap-like structure. Exotesta of short sclerenchyma cells with undulate anticlinal walls, resulting in stellateundulate facets and a jigsaw puzzle-like pattern on the seed surface.

Comments on the genus. Seeds of Anaspermum resemble many of the anatropous exotestal seeds described from the Early Cretaceous of Portugal and Virginia, USA, such as Gastonispermum and Pazliopsis (see above). However, seeds of Anaspermum are distinct in having the outer layer of the seed coat composed of short, flattened, rather than palisade-shaped, cells and the hilar scar and micropyle borne on a cap-like structure.

\section{Anaspermum operculatum E.M.FriIS, P.R.Crane et K.R.Pedersen sp. nov. Text-fig. $15 \mathrm{~d}-\mathrm{j}$}

H o l o t y p e. Designated here. S136740 (Torres Vedras sample 43; figured Text-fig. 15d).

Plant Fossil Names Registry Number. PFN000455 (for new species).

P a ratypes. Designated here. S174608 (Torres Vedras sample 38); S136739, S136742, S136743, S136746, S170071, S170082-S170084, S170093, S174990 (Torres Vedras sample 43).

Rep o s it ory. Palaeobotanical Collections, Department of Palaeobiology, the Swedish Museum of Natural History, Stockholm, Sweden.

E ty m o log y. From Latin: operculum referring to the presence of an operculum at the micropyle region. 

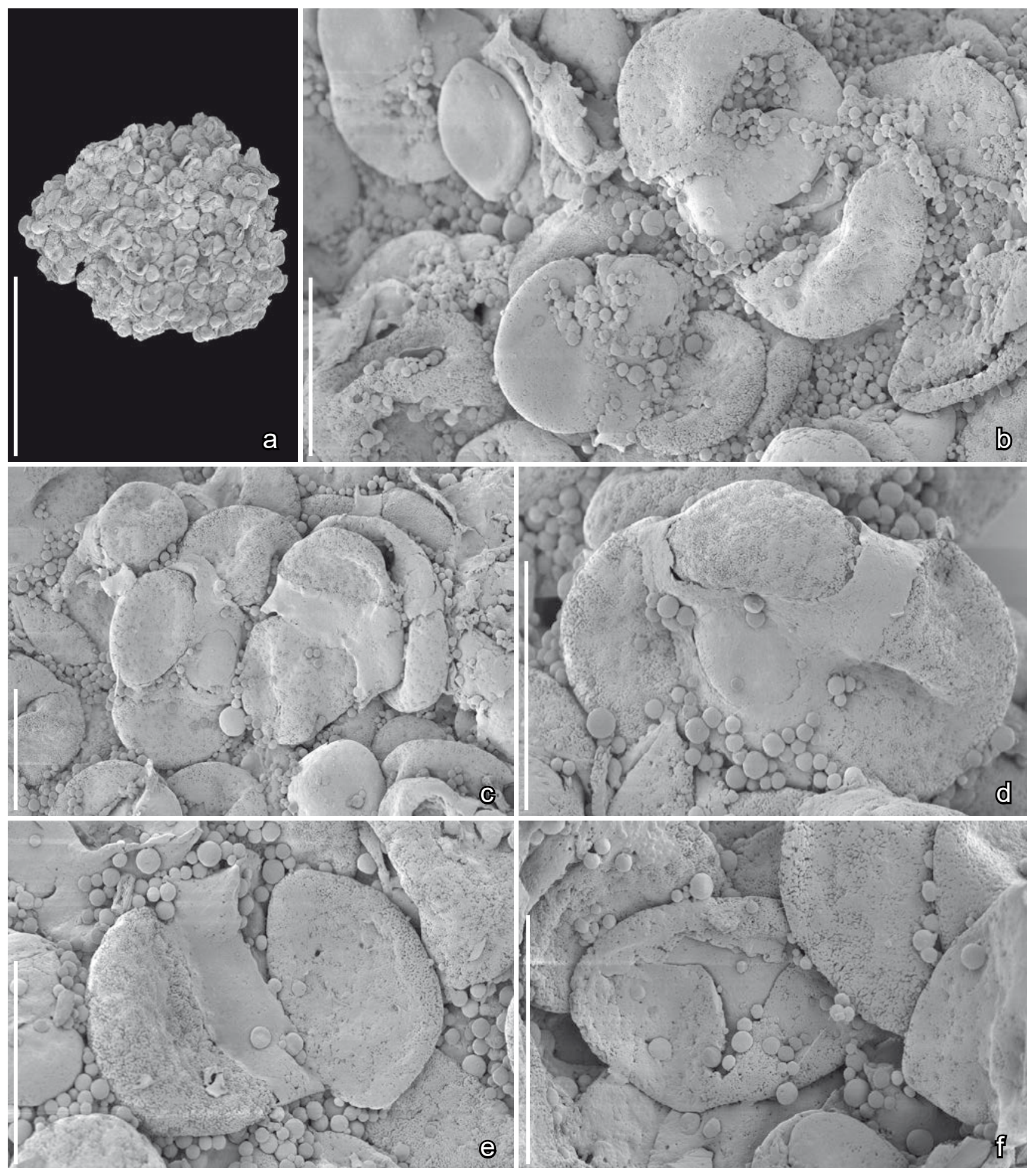

Text-fig. 13. Scanning electron microscope (SEM) images of pollen or spore clump with pollen grains or spores of unknown affinity that occur separately or adhering together in dyads, triads and tetrads; Torres Vedras locality, Portugal. a) Clump of pollen or spores that yielded the pollen or spores in this Text-figure; $b-f)$ Grains adhering together in twos, threes or fours (b-e) or occurring singly and apparently with a proximal trilete mark (f); note that the adhering grains are connected by a smooth bandlike covering, perhaps remains of the microspore mother cell; note also abundant orbicules of various sizes among and over the grains. Specimen, TV44-S148149. Scale bars $300 \mu \mathrm{m}$ (a), $30 \mu \mathrm{m}$ (b-f).

Type locality. Torres Vedras (NE of Forte de Forca; $\left.39^{\circ} 06^{\prime} 13^{\prime \prime} \mathrm{N}, 9^{\circ} 14^{\prime} 47^{\prime \prime} \mathrm{W}\right)$.

Type stratum and age. Lower member of the Almargem Formation; Early Cretaceous (late Barremianearly Aptian).
D i a g n o s is. As for the genus.

D i m e n s i o n s . Length of seed: $0.7-8.4 \mathrm{~mm}$; width of seeds: $0.42-0.6 \mathrm{~mm}$

Description and remarks. The seeds occur singly and isolated, and there is no information on the 

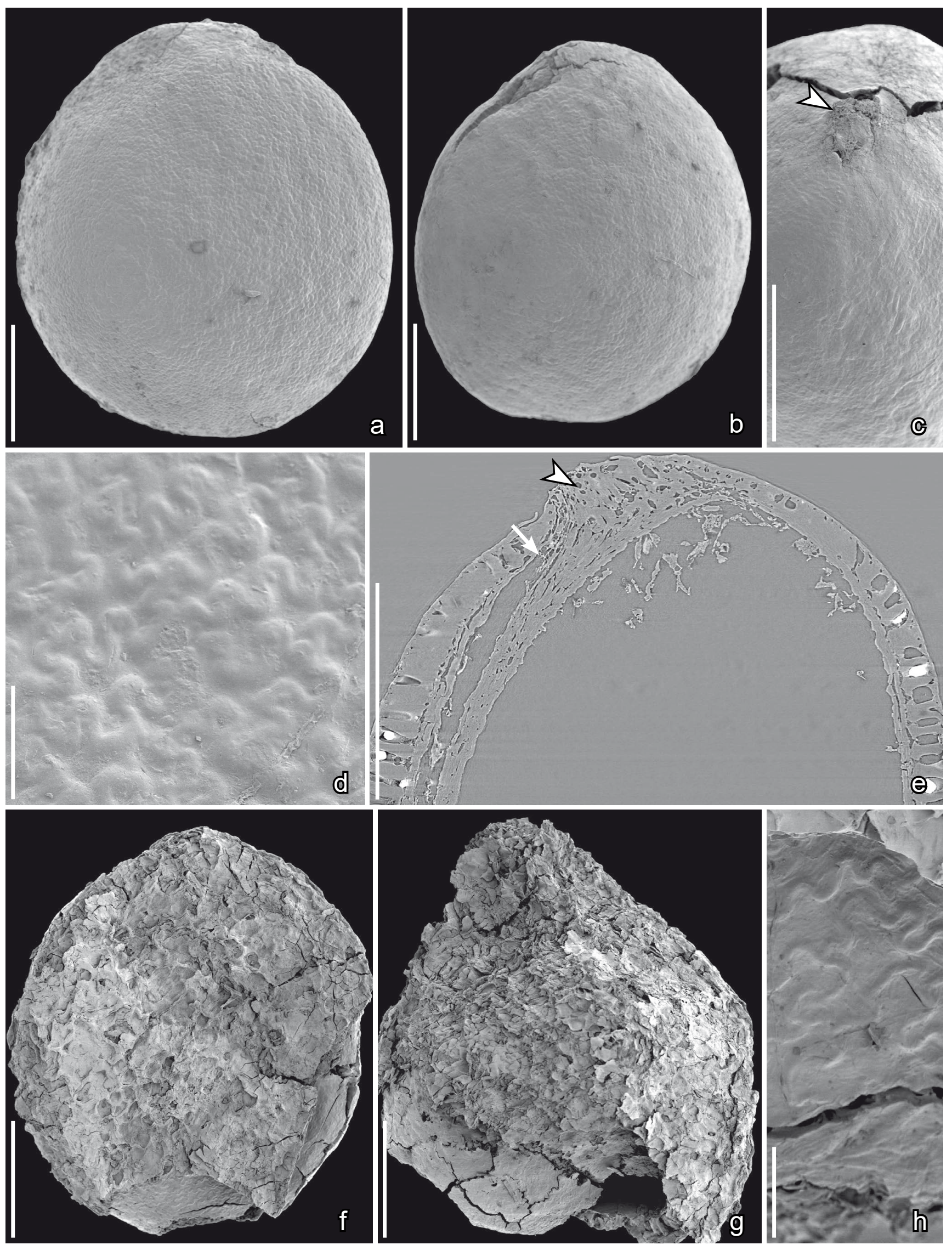

Text-fig. 14. Scanning electron microscope (SEM) and synchrotron radiation X-ray tomographic microscopy (SRXTM) images of seeds of Gastonispermum antiquum sp. nov. (a-e) and possible fruits (f-h); Torres Vedras locality, Portugal. a-c) Lateral view of seeds (holotype figured in b) showing the hilar-micropylar area and the course of the raphe; note the close association of hilum (arrowhead) and micropyle; d) Detail of seed wall showing the undulating surface of the exotesta composed of cells with sinuous cell outlines; e) Longitudinal section (orthoslice xy0914) through the hilar-micropylar area showing the hilum (arrowhead), the thickening of the endotesta around the micropyle and the course of the raphe within the exotesta (arrow); f-h) Fruits containing 
fruit or other parts of the plant. The seeds were illustrated earlier, but not formally described or named (Friis et al. 2010a). They are small, elliptical to ovate in lateral view and elliptical in transverse section (Text-fig. 15d-f, h, i). They are anatropous with the hilar scar and micropyle close together on an apical cap-like structure (Text-fig. 15d, e) that is sometimes shed (Text-fig. 15h). The course of the raphe is seen as a slightly raised rib extending from hilum to the chalazal end of the seed (Text-fig. 15d, e, i). The seeds have an almost smooth surface with a faint jigsaw puzzle-like pattern formed from the slightly raised anticlinal walls of the exotesta sclerenchyma that are stellate-undulate folded near the surface of the seed (Text-fig. $15 \mathrm{~g}$ ).

Affinity and other occurrences. The cap-like structure with micropyle and hilar scar resembles the germination lid seen in seeds of extant and fossil Nymphaeales. Together with the undulate outline of the exotestal cells this feature strongly suggests a nymphaealean affinity for Anaspermum operculatum. Small seeds, very similar to Anaspermum operculatum, are also known from the Buarcos locality, but details of the micropylar area are not known for these seeds.

\section{Nymphaeales-Austrobaileyales seed sp. 1 Text-fig. 16a, b}

Description and remarks. The seed is fragmentary without remains of the fruit. It was illustrated earlier but not formally described or named (Friis et al. 2010a). The seed is small, about $0.65 \mathrm{~mm}$ long and $0.57 \mathrm{~mm}$ wide, anatropous and exotestal. The seed occurs isolated and singly (Text-fig. 16a). It is bilaterally symmetrical with a dorsiventral plane of symmetry and has an almost smooth surface without longitudinal ridges. The course of the raphe is seen as a slightly raised ridge. In the hilar-micropylar region there is a rounded opening, perhaps indicating abscission of a germination lid, but the presence of a germination lid cannot be confirmed and there is no trace of micropyle or hilar scar. The exotesta consists of short sclerenchyma cells with weakly undulate anticlinal walls resulting in stellateundulate facets and a jigsaw puzzle-like pattern on the seed surface (Text-fig. 16b).

Affinity and other occurrences. The seed is closely similar to seeds of Anaspermum operculatum, but the micropylar region is not sufficiently well preserved for a detailed comparison. The two species also differ in the outline of the anticlinal walls on the surface of the exotesta. In $A$. operculatum the anticlinal walls are slightly raised and each cell has several folds, while in "NymphaealesAustrobaileyales seed sp. 1" the anticlinal walls are not raised and there are fewer folds per cell.

\section{Nymphaeales-Austrobaileyales seed sp. 2 \\ Text-fig. 16c, d}

Description and remarks. The seed is small and preserved only as a fragment without remains of the fruit. It was illustrated earlier but not formally described or named (Friis et al. 2010a). It is about $0.7 \mathrm{~mm}$ wide, anatropous and exotestal, and occurs isolated and singly (Text-fig. 16c). The seed is bilaterally symmetrical with a dorsiventral plane of symmetry and an almost smooth surface. It is fractured along the raphe and the fracture obscures the hilar-micropylar region. The exotesta consists of short sclerenchyma cells with deeply undulate anticlinal walls resulting in stellateundulate facets and a jigsaw puzzle-like pattern on the seed surface (Text-fig. 16d).

Affinity and other occurrences. The seed is closely similar to seeds of Anaspermum operculatum and other seeds described here that are compared to seeds of extant Nymphaeales-Austrobaileyales, but the fragmentary nature of the single specimen does not permit detailed comparison. The seed differs from similar seeds from Torres Vedras and other mesofossil floras from Portugal in the nature of the exotestal cells and the degree of folding of the anticlinal walls.

\section{Nymphaeales-Austrobaileyales seed sp. 3 Text-fig. 16e, f}

Description and remarks. The single isolated seed is small, about $0.8 \mathrm{~mm}$ long and $0.75 \mathrm{~mm}$ wide, anatropous and exotestal. It is bilaterally symmetrical with a dorsiventral plane of symmetry, almost circular in lateral view (Text-fig. 16e) and has an almost smooth surface. The course of the raphe is seen on the outside of the seed as a slightly raised ridge extending from the hilum to the base of the seed. The micropylar region is damaged, but the micropyle appears to be somewhat separated from the hilum. The seed is perforated by three holes, probably formed from larvae feeding on the nutritive tissue of the seed. The exotesta consists of sclerenchymatic palisade cells with undulate anticlinal walls that result in stellate-undulate facets and a jigsaw puzzle-like pattern on the seed surface (Text-fig. 16f).

Affinity and other occurrences. The seed shows some resemblance to the seeds of Gastonispermum antiquum, but is much smaller and differs in the arrangement of the hilum and micropyle.

Order Chloranthales R.Br. ex SIMS, 1821

Genus Canrightia E.M.Fris et K.R.PEDERSEN, 2011

\author{
Canrightia elongata E.M.FriIS, P.R.CrANE et \\ K.R.Pedersen sp. nov. \\ Text-fig. $17 \mathrm{a}-\mathrm{g}$
}

H o l o t y p e. Designated here. S174100 (Torres Vedras sample 38; figured Text-fig. 17a-g).

Plant Fossil Names Registry Number. PFN000456 (for new species).

exotestal seeds resembling Gastonispermum antiquum sp. nov. showing poorly preserved thin fruit wall (f, g) and seed with a smooth surface (h). Specimens, TV43-S136738 (a, d), TV43-S136736 (holotype; b), TV43-S136737 (c), TV298-S174629 (e), TV43-S136748 (f, h), TV43-S136749 (g). Scale bars $300 \mu \mathrm{m}(\mathrm{a}, \mathrm{b}, \mathrm{f}, \mathrm{g}), 200 \mu \mathrm{m}(\mathrm{e}), 30 \mu \mathrm{m}$ (c, d, h). 

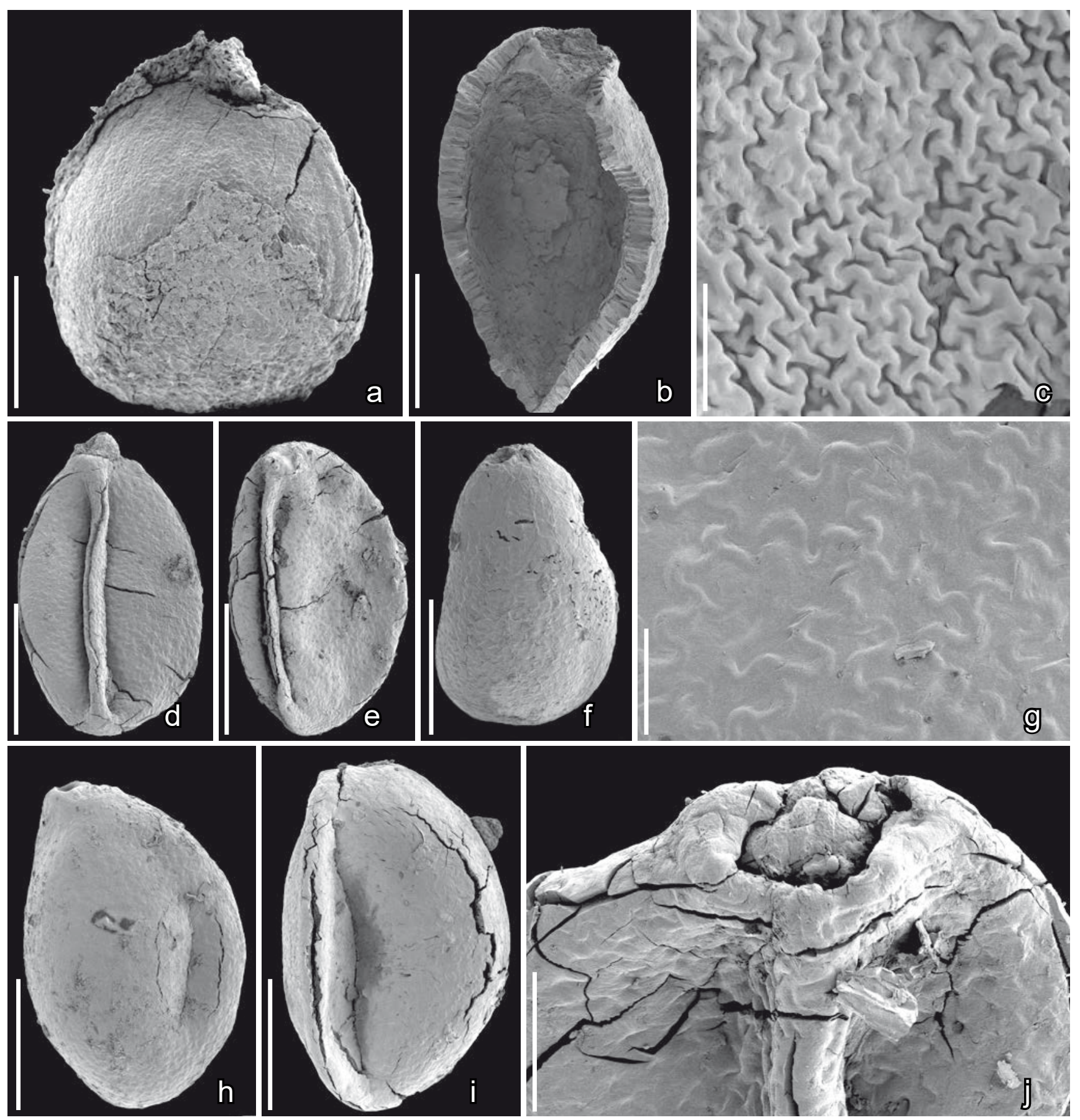

Text-fig. 15. Scanning electron microscope (SEM) images of seeds of Pazliopsis reyi (a-c) and Anaspermum operculatum gen. et sp. nov. $(d-j)$. a) Seed in lateral view showing poorly preserved remains of fruit wall and rough surface of the exotesta; $b$ ) Section through the wall of a broken seed showing palisade cells of the exotesta; c) Seed surface showing sunken very deeply sinuous outlines of the exotesta cells; $d-f, h, i)$ Seeds in lateral view (holotype figured in d) showing the pointed micropylar-hilar area, the rounded chalazal end, the smooth surface of the exotesta composed of cells with sinuous cell outlines, and the distinct course of the raphe; g) Surface of the exotesta showing the distinctive cell outlines formed by the sinuous anticlinal walls of the palisade cells; j) Apical view of seed showing the prominent operculum. Specimens, TV43-S171534 (a), TV44-S136683 (b), TV43-S136745 (c), TV43-S136740 (holotype; d), TV43-S136746 (e), TV43-S136739 (f), TV43-S170083 (g), TV S136743 (h), TV43-S136742 (i), TV38-S174608 (j). Scale bars $300 \mu \mathrm{m}(\mathrm{a}, \mathrm{b}, \mathrm{d}-\mathrm{f}, \mathrm{h}, \mathrm{i}), 50 \mu \mathrm{m}(\mathrm{j}), 30 \mu \mathrm{m}(\mathrm{c}, \mathrm{g})$.

Re po s i t ory. Palaeobotanical Collections, Department of Palaeobiology, the Swedish Museum of Natural History, Stockholm, Sweden.

Etymology. From Latin: elongatus referring to elongate shape of the fruit and seeds.

Type locality. Torres Vedras (NE of Forte de Forca; $39^{\circ} 06^{\prime} 13^{\prime \prime} \mathrm{N}, 9^{\circ} 14^{\prime} 47^{\prime \prime} \mathrm{W}$ ).
Type stratum and age. Lower member of the Almargem Formation; Early Cretaceous (late Barremianearly Aptian).

Specific diagnosis. Fruit elongate, obovoid with a short, conical hypanthium. Stigmatic area sessile, indistinct. Ovules pendant, orthotropous to semiorthotropous, bitegmic, endotestal-endotegmic; testa 

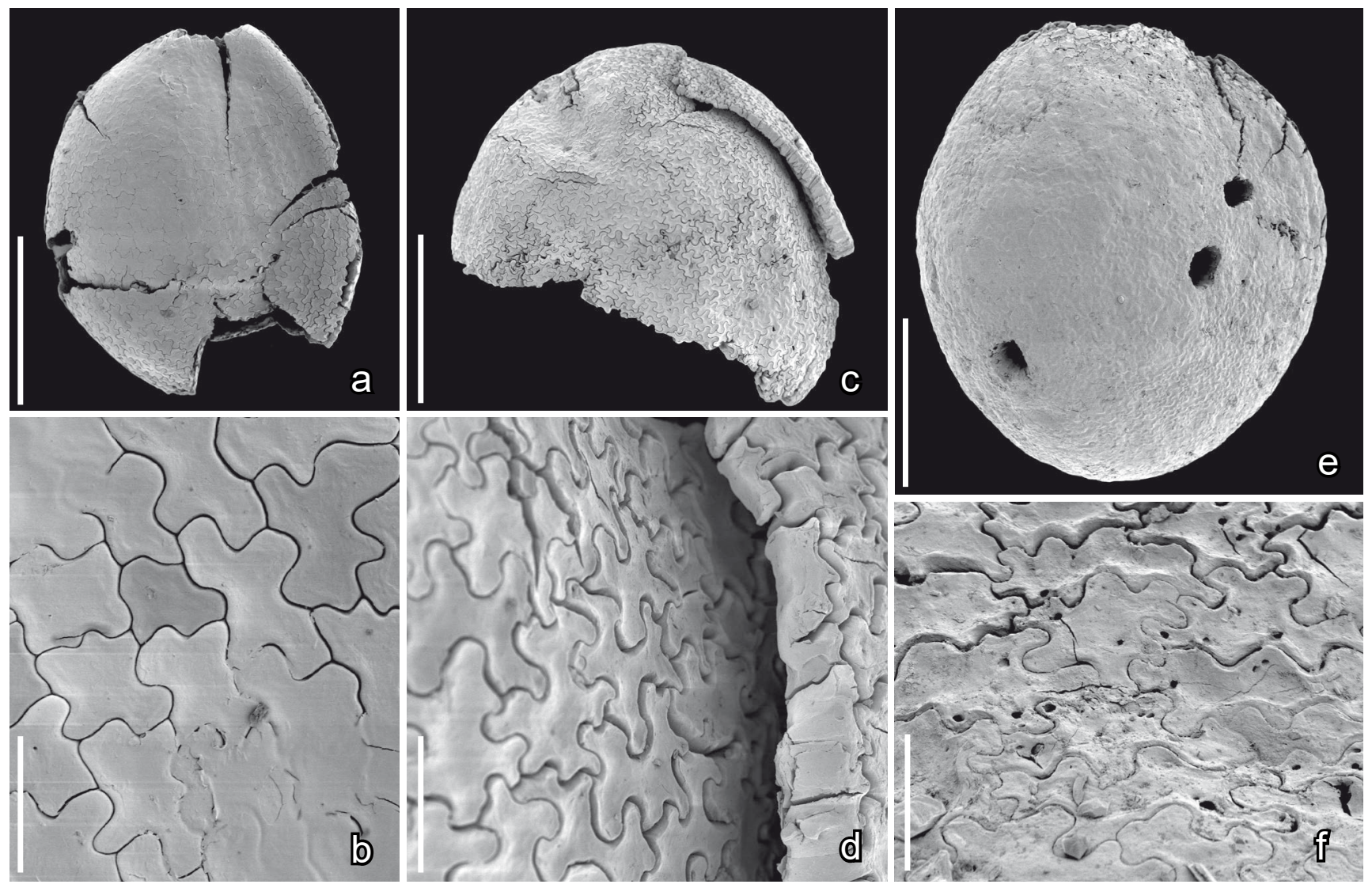

Text-fig. 16. Scanning electron microscope (SEM) images of seeds of possible Nymphaeales-Austrobaileyales affinity; Torres Vedras locality, Portugal. a, b) Nymphaeales-Austrobaileyales seed sp. 1, seed in lateral view (a) showing smooth surface of the exotesta composed of cells with shallowly sinuous cell outlines (b); c, d) Nymphaeales-Austrobaileyales seed sp. 2, fragmentary seed in lateral view (c) showing surface of exotesta composed of cells with deeply sinuous cell outlines (d); e, f) Nymphaeales-Austrobaileyales seed sp. 3, seed in lateral view (e) showing detail of smooth surface of the exotesta composed of cells with sinuous cell outlines (f). Specimens, TV43-S136741 (a, b), TV43-S148142 (c, d), TV43-S170087 (e, f). Scale bars $300 \mu \mathrm{m}$ (a, c, e), $30 \mu \mathrm{m}$ (b, d, f).

comprising two cell layers; exotesta thin; endotesta with cubic to palisade-shaped crystal cells and fibrous infillings; tegmen three cell layers thick; exotegmen of elongated fibrous cells, mesotegmen with cubic thin-walled cells and endotegmen with large, palisade-shaped cells that form an endothelium; endotegmen cells with infilling of tannin. Fruit a sessile berry with three seeds. Fruit wall with densely spaced cavities from presumed oil cells.

D ist inguishing features. Canrightia elongata is distinguished from the only other species of the genus, Canrightia resinifera E.M.FriIs et K.R.Pedersen, by its more elongated shape and shorter, conical, hypanthium.

D i m e n s i o n s . Length of fruit: $1.2 \mathrm{~mm}$; width of fruit: $0.65 \mathrm{~mm}$.

Description and remarks. The new species is based on a single fruit, containing three seeds, which has been studied using SEM and SRXTM. The fruit is closely similar to fruits of Canrightia resinifera described from other localities in Portugal, but differs especially in the shape of the elongated fruit and the short conical hypanthium. The hypanthium is short, about one quarter the length of the fruit (Text-fig. 17a-c), and the fruit as well as the hypanthium is subtended by a short bract (Text-fig. 17c). The hypanthium has four radially arranged triangular lobes that we interpret as reduced tepals. Each lobe subtends a scar interpreted as staminal scar, and the four scars suggest an androecium composed of four stamens (Text-fig. 17c).

Cellular details of the fruit wall are not preserved, except for densely spaced circular openings near the surface of the fruit (Text-fig. 17a-f) that we interpret as empty oil cells. The fruit contains three bitegmic, orthotropous and pendant seeds. The outer layer of the testa (exotesta) is thin, with no cellular details preserved, and is difficult to distinguish from the fruit wall. The inner layer of testa (endotesta) is distinct, one cell layer deep and consists of palisade-shaped cells with a fibrous infilling that contains the angular imprints of crystals. These endotesta cells are similar to the endotesta cells of Canrightia resinifera. The outer surface of endotesta appears almost smooth without depressions or longitudinal ridges.

One of the seeds has a well-developed inner layer of the tegmen (endothelium) while the two other seeds have remains of nutritive tissue and one contains remains of an embryo at the micropylar end. This suggests that two of the seeds were close to maturity while the third may have been aborted.

Two isolated seeds (Text-fig. 17h, i) that have a crystalliferous seed coat (Text-fig. 17j) may be seeds of Canrightia elongata or Canrightia sp. These seeds are very similar to seeds of Canrightia resinifera, but the larger crystals in the endotesta are scattered and surrounded by 

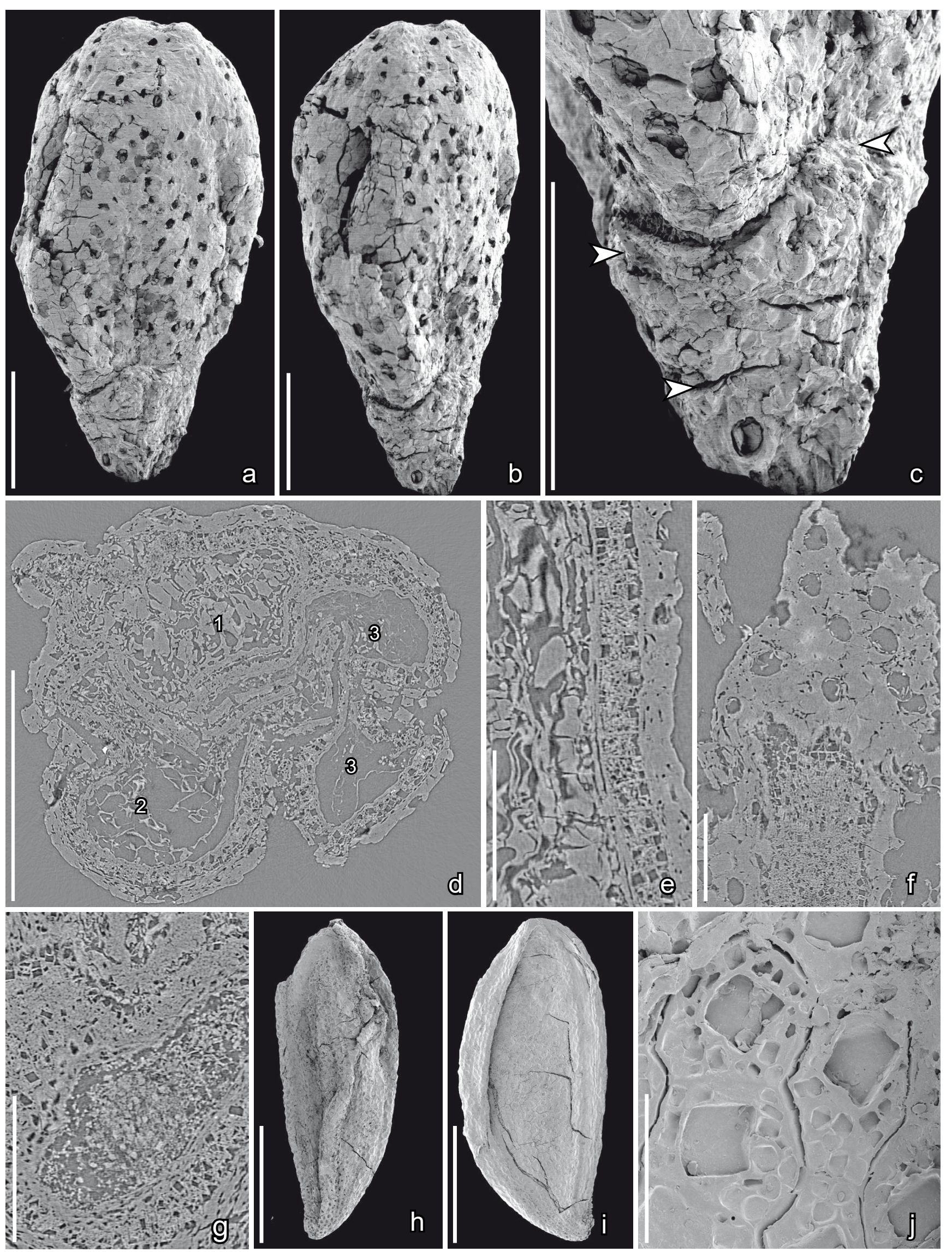

Text-fig. 17. Scanning electron microscope (SEM) and synchrotron radiation X-ray tomographic microscopy (SRXTM) images of a fruit of Canrightia elongata sp. nov. (a-g) and isolated Canrightia-like seeds (h-j); Torres Vedras locality, Portugal. a-c) Holotype; fruit in lateral view showing four fused tepals at the base (c, upper arrowheads) and prominent cavities in the fruit wall formed by scattered oil bodies and possible subtending bract (c, lower arrowhead); d) Transverse section (SRXTM orthoslice xy1510) through the fruit showing three locules, one with the remains of the endothelium (top left, 1$)$, the other two $(2,3)$ with remains of presumed endosperm tissue; note that the locule to the right (3) is crushed; e, f) Radial longitudinal (e; SRXTM orthoslice xz1212) 
smaller crystals, whereas in $C$. resinifera the large crystals are densely arranged in the outer part of endotesta.

Affinity and other occurrences.Canrightia is an extinct genus closely related to the clade comprising extant Ascarina J.R.Forst. et G.Forst., Chloranthus Sw. and Sarcandra GARDNER, among extant Chloranthaceae (Friis and Pedersen 2011). Canrightia elongata is currently known only from the Torres Vedras locality. The only other species of the genus, Canrightia resinifera is known based on numerous well-preserved specimens from the Arazede, Buarcos, Catefica, Famalicão and Vale de Água localities (Friis and Pedersen 2011).

\section{Canrightia sp. \\ Text-fig. 18a-e}

Description and remarks. A single fruit of Canrightia containing several seeds has been studied using SEM and SRXTM. The fruit is closely similar to fruits of Canrightia resinifera. However, the specimen from Torres Vedras differs in several features, as well as details of the associated pollen, and cannot be assigned to the same species. The fruit is broadly elliptical in lateral view with rounded apex and base (Text-fig. 18a), about $1.25 \mathrm{~mm}$ long and $0.95 \mathrm{~mm}$ broad. It is lignitised and compressed laterally and internal features are poorly preserved. The fruit contains three or four seeds, but none clearly shows details of the seed coat. The hypanthium is broad with a distinct rim (Text-fig. 18a). Five radially arranged scars at the rim of the hypanthium almost certainly indicate the position of five stamens. The epidermis of the fruit wall is composed of polygonal and equiaxial cells, among which are scattered rounded cells, or openings of cells, that are thought to be oil cells (Text-fig. 18b).

Pollen grains concentrated on the probable stigmatic area of the fruit are circular in equatorial outline, about $20 \mu \mathrm{m}$ in diameter, with a long colpus that extends for the full length of the grain (Text-fig. 18c, d). The grains are semitectatereticulate with a heterobrochate reticulum that has lumina up to about $1.25 \mu \mathrm{m}$ in diameter (Text-fig. 18d, e). Muri are smooth with an angular profile, and are supported by long, scattered columellae that are typically compressed (Text-fig. 18e). The reticulum is only loosely attached to the foot layer, and several grains (not shown) are naked and have lost the reticulum entirely.

Canrightia sp. is distinguished from Canrightia elongata by its more rounded shape and broader hypanthium, and while Canrightia sp. is more similar to Canrightia resinifera it probably represents a new species of the genus based on differences in the associated pollen. Pollen grains of Canrightia resinifera are semitectate-reticulate and columellate, like those associated with Canrightia sp., but the reticulum in $C$. resinifera is homobrochate and with lumina that are much larger, up to about $3 \mu \mathrm{m}$ in diameter. Notwithstanding these differences poor preservation of the internal features of Canrightia sp. precludes establishing a new species.

Affinity and other occurrences.Canrightia sp. occurs, together with $C$. elongata, only at the Torres Vedras locality. Like Canrightia resinifera and C. elongata, Canrightia sp. is closely related to the clade comprising extant Ascarina, Chloranthus and Sarcandra, among extant Chloranthaceae. The pollen grains show some resemblance to grains of Eckhartia longicolumella described here from the Torres Vedras mesofossil flora (p. 210 herein), but they differ in the angular profile of the muri.

\section{Genus Kvacekispermum E.M.FriIS, P.R. CRANE et K.R.Pedersen, 2018}

\section{Kvacekispermum costatum E.M.FriIS, P.R. CRANE et K.R.PEDERSEN sp. nov. Text-fig. 19a-c}

H o l o t y p e. Designated here. S174098 (Torres Vedras sample 38; figured Text-fig. 19a).

Plant Fossil Names Registry Number. PFN000457 (for new species).

P a r a t y p e. Designated here. S174099 (Torres Vedras sample 38).

Re p o s i tory. Palaeobotanical Collections, Department of Palaeobiology, the Swedish Museum of Natural History, Stockholm, Sweden.

Etymology. From Latin: costatus referring to longitudinal ridges on the surface of the endotesta.

Type locality. Torres Vedras (NE of Forte de Forca; 39 $06^{\prime} 13^{\prime \prime} \mathrm{N}, 9^{\circ} 14^{\prime} 47^{\prime \prime} \mathrm{W}$ ).

Type stratum and age. Lower member of the Almargem Formation; Early Cretaceous (late Barremianearly Aptian)

Specific diagnosis. Seeds tiny, broadly obovate in lateral view and almost circular in transverse section with an uneven surface of the endotesta formed from numerous longitudinal ridges separated by shallow depressions. Endotesta comprised of a single layer of palisade-shaped cells with densely spaced crystals and fibrous infillings.

Distinguishing features. Kvacekispermum costatum is distinguished from Kvacekispermum rugosum E.M.Fris, P.R.Crane et K.R.Pedersen described from the Catefica locality (Friis et al. 2018c) by its much smaller

and tangential longitudinal (f; SRXTM orthoslice yz0246) sections showing the amorphous fruit wall with prominent cavities formed by the scattered oil bodies (f); note the crystalliferous cells of the endotesta with endoreticulate infillings and outlines of small crystals (e); g) Longitudinal section (SRXTM orthoslice yz0490) showing the small poorly developed embryo surrounded by the crystalliferous cells of the endotesta; $h$, i) Probable seeds of Canrightia in lateral view showing the rounded point of attachment (above) and the pointed micropylar region (below); j) Crystalliferous cells of the endotesta showing crystals of two distinct sizes. Specimens, TV38-S164100 (holotype; a-g), TV43-S170069 (h), TV43-S170068 (i, j). Scale bars $300 \mu \mathrm{m}(\mathrm{a}-\mathrm{d}, \mathrm{h}, \mathrm{i}), 100 \mu \mathrm{m}$ (e-g), $20 \mu \mathrm{m}(\mathbf{j})$. 

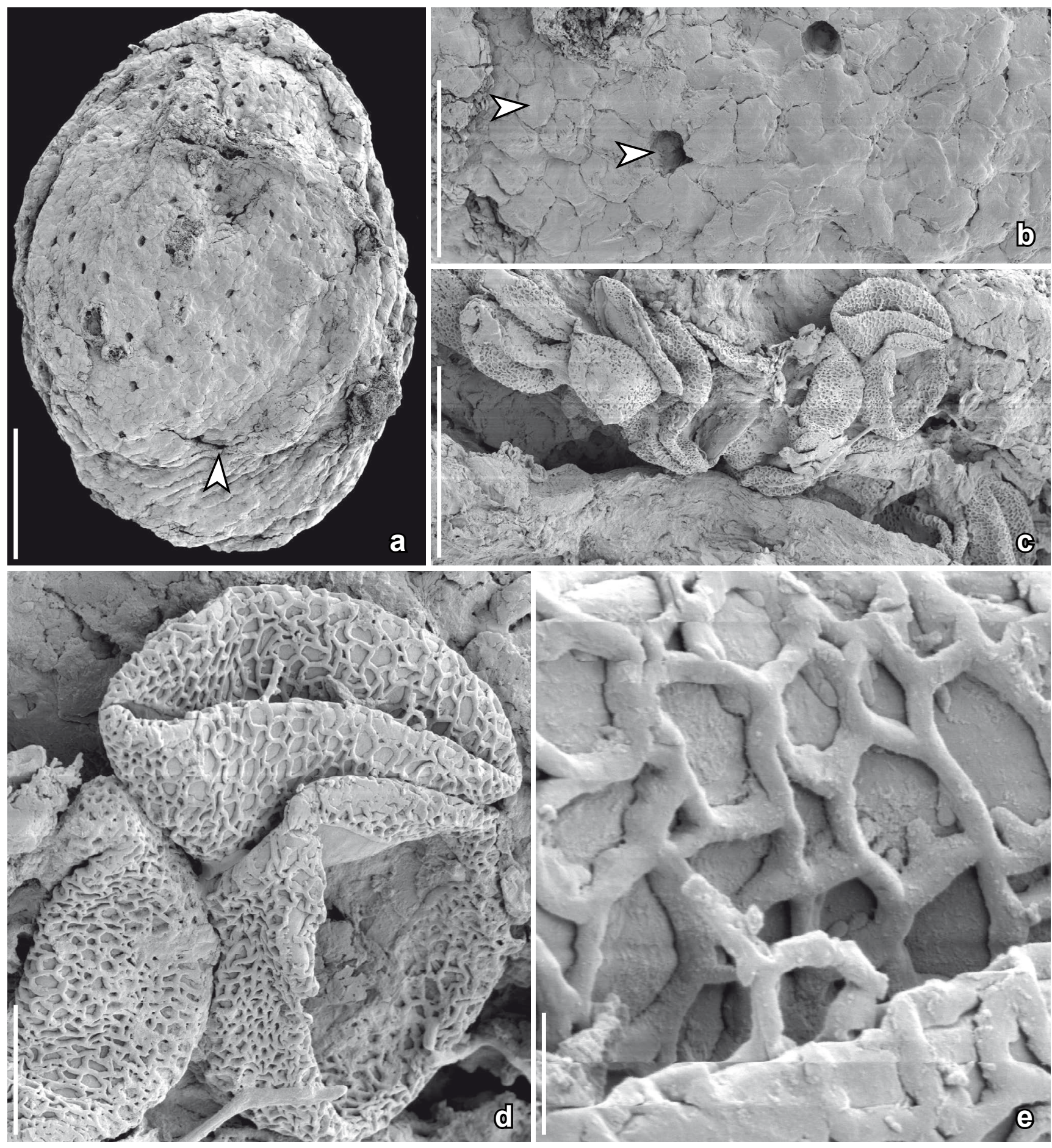

Text-fig. 18. Scanning electron microscope (SEM) images of a fruit of Canrightia sp. with associated pollen; Torres Vedras locality, Portugal. a) Fruit in lateral view showing prominent cavities in the fruit wall formed by the scattered oil bodies and the broad hypanthium fused to the base of the fruit (arrowhead); b) Fruit surface showing epidermal cells and the scattered oil cells embedded in the fruit wall (arrowheads); c) Cluster of monocolpate pollen grains in the probable stigmatic region of the fruit; d) Pollen grains showing the long colpus and semitectate-reticulate pollen wall; e) Pollen wall showing the reticulum with large and small lumina, and scattered, compressed columellae supporting the smooth muri. Specimen, TV142-S170213. Scale bars $300 \mu \mathrm{m}$ (a), $100 \mu \mathrm{m}$ (b), $30 \mu \mathrm{m}$ (c), $6 \mu \mathrm{m}$ (d), $1 \mu \mathrm{m}$ (e).

size (about half the length of $K$. rugosum) and by the more numerous longitudinal ridges (about 35 ridges in $K$. costatum and about 20 in K. rugosum). Seeds of Kvacekispermum are distinguished from seeds of Canrightiopsis E.M.FrIIs, G.W.Grimm, M.M.Mendes et K.R.Pedersen (Friis et al. 2015 b) by their strongly ribbed seed surface.
D imensions. Length of seed: $0.6 \mathrm{~mm}$; width of seeds: $0.4-0.5 \mathrm{~mm}$.

Description and remarks. Remains of the apical part of the fruit show a sessile rounded stigmatic area (Text-fig. 19a, b). There are no remains of hypanthium or 
other parts of the flower. The seeds are very small, elliptical to ovoid with pointed micropylar region. Both seeds were studied using SRXTM, but they are lignitised, strongly compressed and with an almost homogenized seed coat. Cellular details are best observed on the outer surface which shows crystal cells with equiaxial facets (Text-fig. 19c) very similar to the endotestal cells of Kvacekispermum rugosum as well as those of other Early Cretaceous chloranthoids. The surface of the endotesta is characterized by about 35 densely-spaced, rounded longitudinal ridges that extend from base to apex, and densely-spaced shallow and rounded depressions between the ridges (Text-fig. 19a-c).

Affinity and other occurrences. Like Kvacekispermum rugosum, $K$. costatum is an extinct species closely related to the clade comprising extant Ascarina, Chloranthus and Sarcandra, among extant Chloranthaceae (Friis et al. 2018c). Kvacekispermum costatum is currently known only from the Torres Vedras locality, whereas $K$. rugosum is known only from the Vale de Água locality.

\section{Kvacekispermum sp.}

Text-fig. 19d, e

Description and remarks. Kvacekispermum sp. is known from a single obovate seed that is pointed at the micropylar end, rounded at the chalazal end, $1.15 \mathrm{~mm}$ long and $0.55 \mathrm{~mm}$ wide. Remains of the fruit or floral organs are not preserved. The seed is similar to seeds of Kvacekispermum rugosum and $K$. costatum in having a crystalliferous endotesta (Text-fig. 19e) characterized by longitudinal ridges separated by rounded depressions (Textfig. 19d). However, Kvacekispermum sp. has a smaller number of ridges (about 16) than $K$. rugosum and $K$. costatum (about 20 and 35 respectively). The ridges are also rounded and occasionally bifurcate unlike in $K$. costatum and K. rugosum (Text-fig. 19d).

Affinity and other occurrences. Kvaceckispermum sp. is currently known only from the Torres Vedras mesofossil flora. Like Kvacekispermum rugosum and $K$. costatum, Kvaceckispermum sp. is an extinct species closely related to the clade comprising extant Ascarina, Chloranthus and Sarcandra, among extant Chloranthaceae (Friis et al. 2018c).

\section{Genus Hedyflora E.M.Fris, P.R.Crane et K.R.Pedersen, 2019}

Hedyflora sp. 1

Text-fig. 20a, b

Description and remarks. Material of Hedyflora sp. 1 comprises about 20 isolated lignitised fruits showing scars from apically inserted tepals. The fruits are angular-obovate in longitudinal section, triangular in transverse section with sharp edges, and are about $1.3 \mathrm{~mm}$ long and $1 \mathrm{~mm}$ wide. One specimen is three-dimensionally preserved (Text-fig. 20a, b). The other specimens are strongly compressed. The hypanthium wall is thicker over the three edges forming a frame around three distinctive depressions ("windows") (Text-fig. 20a, b). The stigma is abraded or abscised. The hypanthium wall is smooth and lacks papillae. No pollen grains have been observed on the surface of the fruits. The lignitised nature of the Torres Vedras fossils precludes obtaining cellular details by SEM or SRXTM.
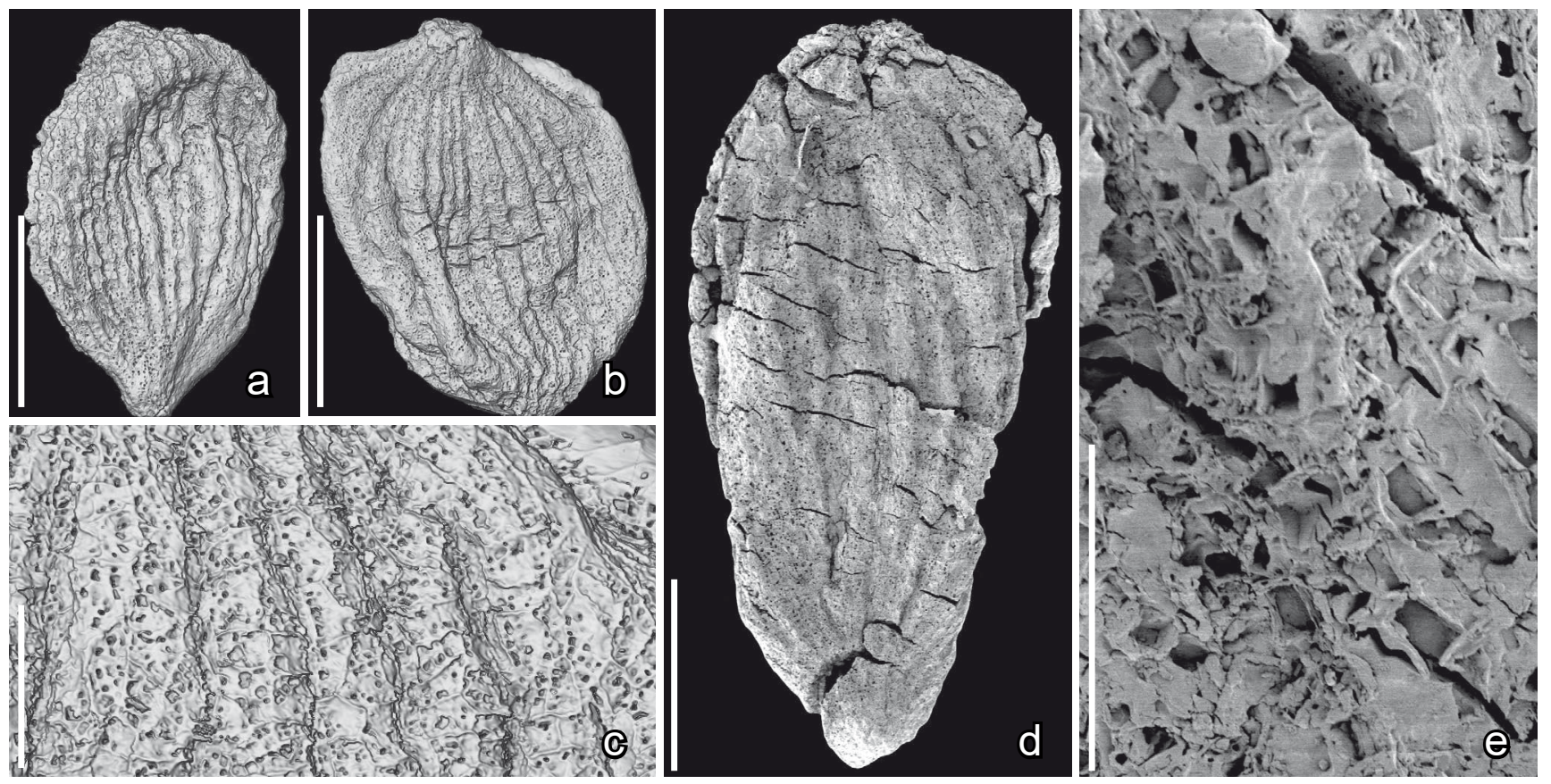

Text-fig. 19. Scanning electron microscope (SEM; d, e) and synchrotron radiation X-ray tomographic microscopy (SRXTM; a-c) images of a seed of Kvacekispermum costatum sp. nov. (a-c) and Kvacekispermum sp. (d, e); Torres Vedras locality, Portugal. a, b) Isolated, abraded seeds showing densely spaced longitudinal ridges; c) Detail of abraded seed in (b) showing surface of endotesta with imprints of crystals; d) Isolated, abraded seed showing longitudinal ridges; e) Abraded seed surface showing surface of endotesta with imprints of crystals. Specimens, TV44-S174098 (holotype; a), TV38-S174099 (b, c), TV43-S174612 (d, e). Scale bars $300 \mu \mathrm{m}(\mathrm{a}, \mathrm{b}, \mathrm{d}), \mathbf{5 0} \mu \mathrm{m}(\mathrm{c}, \mathrm{e})$. 
Affinity and other occurrences. Fruits of Hedyflora sp. 1 are very similar to those of Hedyflora crystallifera E.M.FrIIS, P.R.CRANE et K.R.PEDERSEN described from the Buarcos and Vale de Água localities (Friis et al. 2019 b), but critical anatomical details of $H$. crystallifera, including especially the presence of a distinct crystalliferous endotesta, are not preserved in the Torres Vedras specimens due to their lignitic preservation in which the anatomical structure of the fruit and seed wall is homogenized. Similar, typically lignitic and strongly compressed flowers or fruits also occur in other Early Cretaceous mesofossil floras from Portugal. Hedyflora is a genus closely related to, and part of the stem group, of extant Hedyosmum Sw. (Chloranthaceae).

\section{Hedyflora sp. 2}

Text-fig. 20c, d

Description and remarks. The material comprises two isolated flowers/fruits with three tepals preserved at the apex of the ovary. The specimens are obovate to elliptical in longitudinal section, triangular in transverse section with sharp edges, about $0.9 \mathrm{~mm}$ long and $0.6 \mathrm{~mm}$ wide. The hypanthium wall is thicker over the three edges forming a frame around the three distinctive depressions ("windows") between the ridges (Text-fig. 20c, d). The stigma is abraded or abscised. The hypanthium wall is coarsely papillate in the regions between the ridges. No pollen grains were observed on the surface of the fruits. The Torres Vedras flowers/fruits described are assigned to the genus Hedyflora based on clear morphological similarities to Hedyflora crystallifera described based on abundant and better-preserved material from the Buarcos and Vale de Água localities (Friis et al. 2019b). However, like Hedyflora sp. 1 described above, details of seed coat anatomy are unknown.

Affinity and other occurrences. Fruits of Hedyflora sp. 2 are very similar to those of Hedyflora crystallifera and Hedyflora sp. 1, but they are smaller, and the hypanthium wall has more pronounced verrucae. Hedyflora is a genus closely related to, and part of the stem group, of extant Hedyosmum (Chloranthaceae) (Friis et al. 2019b).

\section{Stamens and pollen clumps with Asteropollis R.W.HedL. et G.Norris, 1968 and Clavatipollenites COUPER, 1958}

R e m a r k s. Many stamens, fragments of stamens and pollen clumps with Asteropollis and Clavatipollenites type pollen are known from the Torres Vedras mesofossil flora, and also from most other Early Cretaceous mesofossil floras from Portugal. The preservation of specimens from the Torres Vedras mesofossil flora is typically more fragmentary than in other floras. The specimens are described only briefly here. Further details, diagnoses and formal names will be provided in a forthcoming paper treating all choranthoid stamens and pollen grains recognized in the Portuguese mesofossil floras.

\section{Stamens with tetrachotomocolpate Asteropollis type pollen \\ Text-fig. 20e-g}

Description and remarks. Stamens up to about $600 \mu \mathrm{m}$ long, typically compressed and fragmented, apparently with two pairs of pollen sacs (Text-fig. 20f). Pollen grains in situ are tetrachotomocolpate, circular in outline and about 15-18 $\mu \mathrm{m}$ in diameter (Text-fig. 20e). The exine is semitectate-reticulate, columellate, with long, scattered columellae (Text-fig. 20g). Lumina are irregular in shape, up to about $1 \mu \mathrm{m}$ in diameter. Muri have a rounded profile with supratectal ornamentation consisting of minute verrucae aligned in two rows along the margins of the muri (Text-fig. 20g).

Affinity and other occurrences. At the Torres Vedras locality, stamens with distinct Asteropollis type pollen are typically found isolated. A staminate inflorescence with many tetrasporangiate stamens in a whorled arrangement (Text-fig. 20h) may represent an early developmental stage of an inflorescence prior to shedding of the stamens. Pollen grains of probable Asteropollis type occur in situ in several stamens, but in all cases the apertures of these grains are only poorly exposed and not sufficiently clear for definitive systematic assignment of these grains to Asteropollis. In other mesofossil floras from Portugal (Buarcos, Catefica, Vale de Água) stamens with Asteropollis type pollen occur isolated or as fragments of staminate inflorescences. Pollen grains associated with Hedyflora crystallifera from Buarcos are slightly larger than the grains from Torres Vedras (about $22 \mu \mathrm{m}$ in diameter) and include both tetrachotomo- and trichotomocolpate forms. It is possible that the Buarcos and Torres Vedras grains belong to different species and none of the Portuguese Asteropollis-type pollen conform completely to Asteropollis asteroides HedLund et NorRIS. The type material of Asteropollis asteroides from the Early Cretaceous (Albian) of Oklahoma, USA, comprises grains characterized by a star-shaped pentachotomocolpate, or rarely a tetrachotomo- or hexachotomocolpate, aperture (Hedlund and Norris 1968).

Similar tetrachotomocolpate Asteropollis type pollen are also reported as Asteropollis cf. asteroides from early Aptian to middle Albian from coastal sections in Portugal (Heimhofer et al. 2007).

\section{Stamens with trichotomocolpate Asterpollis type pollen \\ Text-fig. 21a-h}

Description and remarks. Long, and narrow tetrasporangiate stamens, up to about $700 \mu \mathrm{m}$ long, occur isolated (Text-fig. 21a, c) or in fragments of stamen whorls in which several stamens are attached together (Text-fig. $21 b)$. Pollen grains in situ within the stamens were described by Friis et al. (1999) as type J.3. The grains are almost circular in equatorial outline, about $18-22 \mu \mathrm{m}$ in diameter and trichotomocolpate (Text-fig. 21d, f). The pollen wall is semitectate-reticulate with a homobrochate reticulum. Lumina are irregular and up to about $1.2 \mu \mathrm{m}$ in diameter. Muri are ornamented with tiny verrucae arranged in two rows (Text-fig. 21e, g, h). Columellae are of medium size and widely spaced.

Affinity and other occurrences. The trichotomocolpate pollen grains in situ within the stamens are very similar to pollen of Jusinghipollis ticoensis LLORENS et LoINAzE described from the Aptian of Patagonia (Llorens 

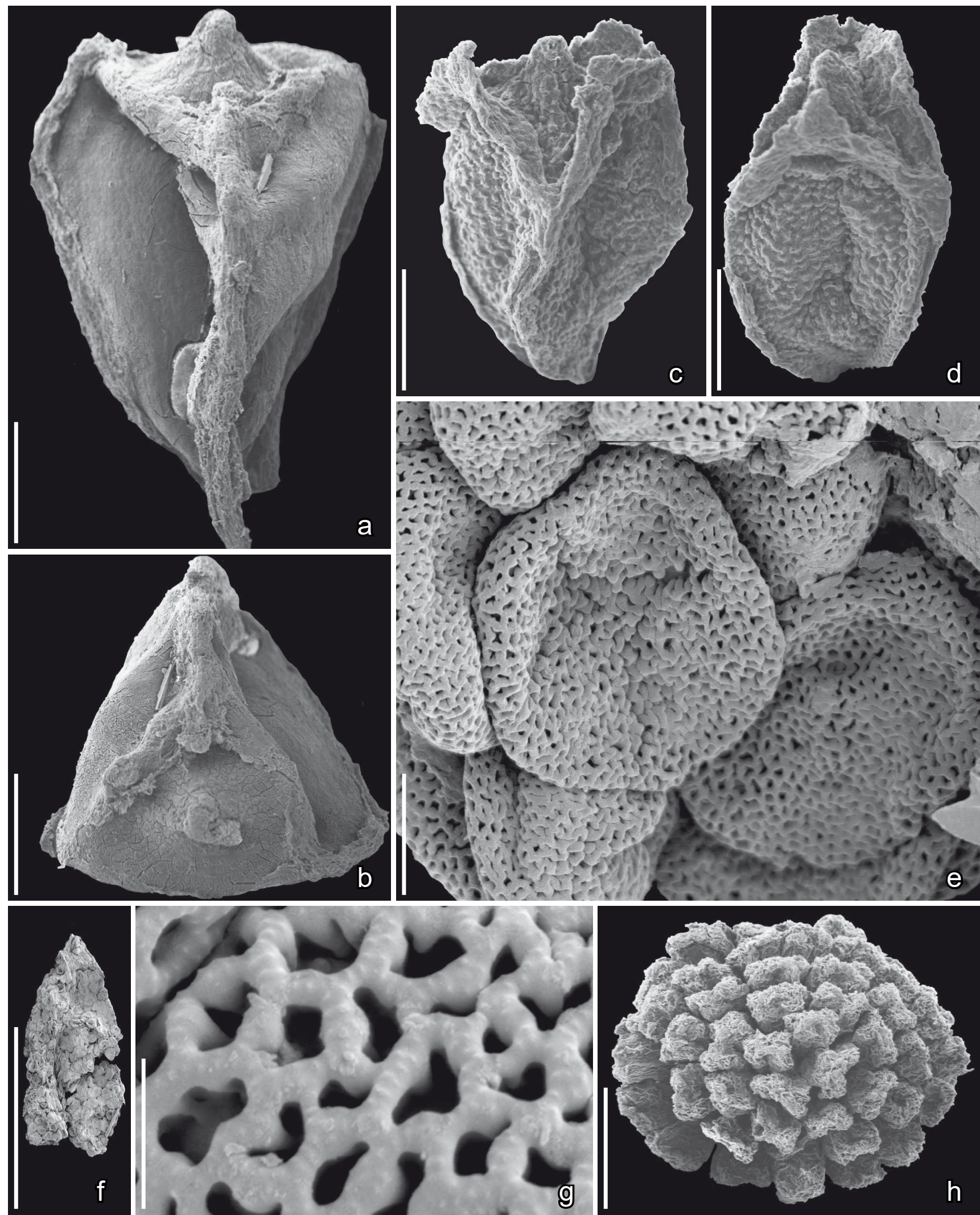

Text-fig. 20. Scanning electron microscope (SEM) images of fruits of Hedyflora (a-d), stamen with in situ Asteropollis sp. pollen (e-g), and Hedyosmum-like staminate inflorescence (h); Torres Vedras locality, Portugal. a, b) Hedyflora sp. 1, lateral and apical views of fruits showing the triangular cross-section, remains of three tepals, apical style and the three lateral "windows" in the hypanthium; c, d) Hedyflora sp. 2, lateral views of fruits showing three well-preserved tepals, apical style and the lateral "windows" in the hypanthium; note the papillae on the lateral wall and around the base of the style; $, \mathrm{f}, \mathrm{g}$ ) Stamen (f) with in situ pollen of Asteropollis sp. showing the poorly defined star-shaped apertural area (e) and reticulate tectum, with the muri ornamented by small verrucae $(\mathrm{g})$; h) Hedyosmum-like staminate inflorescence with five whorls of tetrasporangiate stamens. Specimens, TV43-S101749 (a, b), TV43-S101307 (c, d), TV44-S137917 (e-g), TV39-S101220 (h). Scale bars $300 \mu \mathrm{m}$ (a-d, f, h), $6 \mu \mathrm{m}$ (e), $1.5 \mu \mathrm{m}$ (g). 

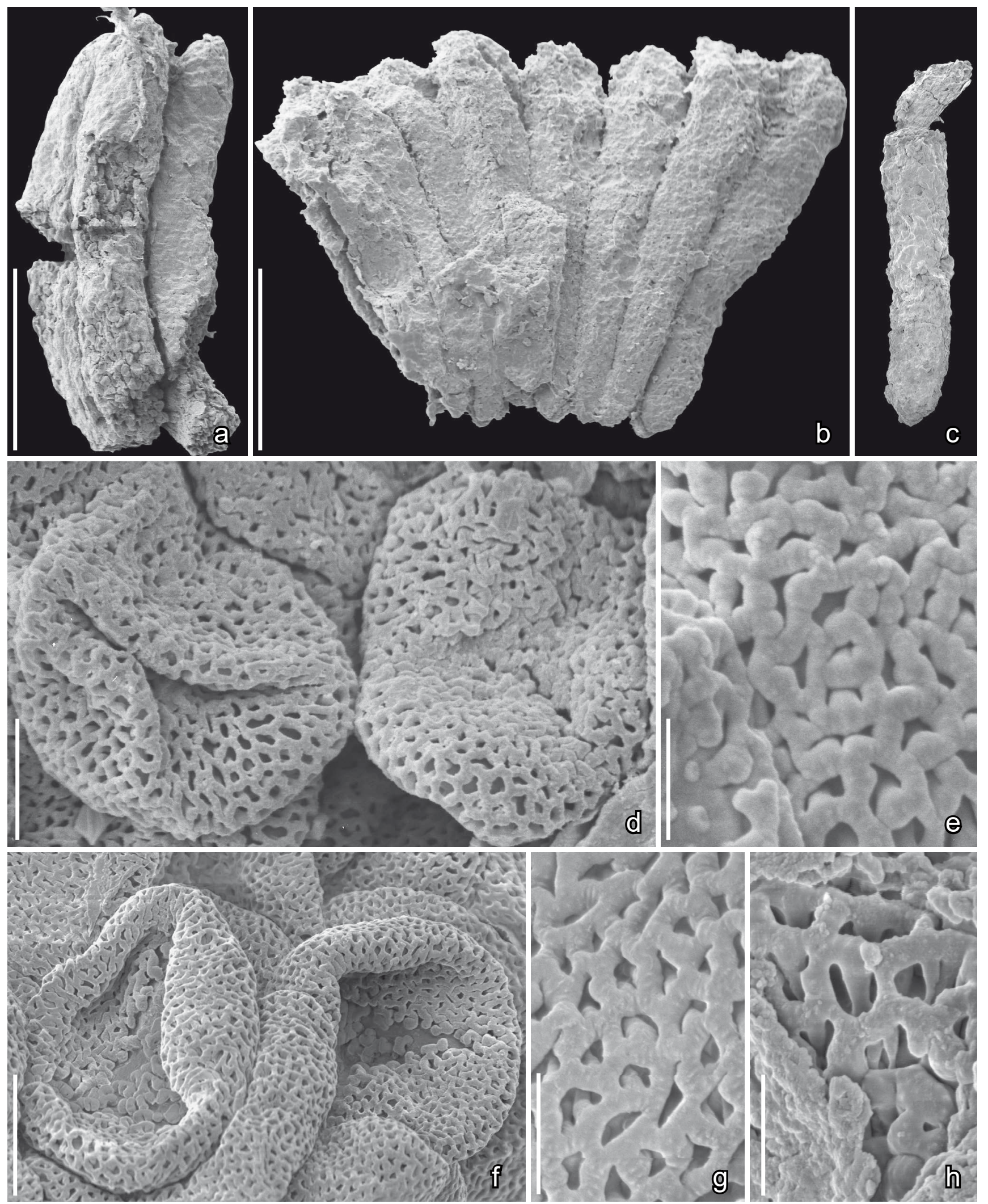

Text-fig. 21. Scanning electron microscope (SEM) images of stamens (a-c) with in situ trichotomocolpate Asteropollis type pollen (dh); Torres Vedras locality, Portugal. a) Fragmentary tetrasporangiate stamen; b) Group of tetrasporangiate stamens; c) Single pollen sac from stamen; d, f) Distal view of pollen grains showing trichotomocolpate aperture; e, g) Pollen wall showing dense reticulum with faint supratectal ornamentation; h) Detail of pollen wall showing numerous long columellae. Specimens, TV44-S105012 (a, d), TV44-105015 (b, e), TV44-S136763 (c, f, g), TV44-S136669 (h). Scale bars $300 \mu \mathrm{m}$ (a-c), $6 \mu \mathrm{m}$ (d, f), $1.5 \mu \mathrm{m}$ (e, g, h).

and Perez Loinaze 2015), but the pollen grains from Torres Vedras differ in their more dense reticulum, broader muri and less pronounced supratectal spines. The Portuguese grains are also closely similar to Jusinghipollis microreticulata (JuHÁsz et Góczán) JANSONIUS et Hills (first described as Singhipollis microreticulatus JuHÁsz et GócZÁN), the type 
species for the genus from the Albian of Hungary (Juhász and Góczán 1985), but J. microreticulata differs in its smaller size and the longer arms of the aperture. There is also close similarity to the pollen described as Trichoto-Beatle from the Aptian and early Albian of Egypt (Penny 1991). Because trichotomocolpate pollen occurs with tetrachotomocolpate Asteropollis type pollen in the same anthers in material from the Buarcos locality (Friis et al. 2019b), we hesitate to assign the Torres Vedras grains to Jusinghipollis rather than to a separate species of Asteropollis. Also the occurrence of the stamens in dense whorls is similar to the arrangement of stamens in extant Hedyosmum and in fossil stamens with Asteropollis type pollen. This suggests a closer relationship to the Hedyosmum-Hedyflora-Asteropollis lineage than to extant Ascarina, which also has trichotomocolpate pollen. In flowers of extant Ascarina the stamens occur either singly or in pairs, and trichotomocolpate pollen often co-occurs in the same anthers with monocolpate pollen.

Trichotomocolpate Asteropollis type pollen reported as Asteropollis sp. 4 from late Aptian to middle Albian from coastal sections in Portugal (Heimhofer et al. 2007) is similar to the Torres Vedras grains, but is larger.

\section{Genus Clavatipollenites COUPER, 1958}

\section{Clavatipollenites sp. 1}

Text-fig. 22a-g

Description and remarks. The material comprises several fragments of small tetrasporangiate stamens with pollen in situ (Text-fig. 22a, b). The anthers are up to about $0.52 \mathrm{~mm}$ long. Pollen grains in situ within the stamens were described by Friis et al. (1999) as type J.1. The grains are monoaperturate and almost circular in equatorial outline, about $14-16 \mu \mathrm{m}$ in diameter, semitectatereticulate with a homobrochate reticulum (Text-fig. 22c-f). Lumina are irregular and up to about $1.2 \mu \mathrm{m}$ in diameter. Muri are ornamented with tiny verrucae arranged in two rows. Columellae are of medium size and widely spaced (Text-fig. 22g). The aperture is broad, rounded and covered by irregular verrucae that grade into the reticulum in the non-apertural regions of the grains (Text-fig. 22c-e).

Affinity and other occurrences. In their general shape, form of the pollen wall, and the indistinctly delimitated aperture, these pollen grains are similar to various dispersed pollen assigned to the genus Clavatipollenites. Pollen grains of Clavatipollenites are usually compared to pollen of extant Ascarina. However, the pollen described here differs from that of extant Ascarina in having a very broad and rounded colpus. Similar pollen to the fossil grains described here also occur in several stamens recovered from the Catefica mesofossil flora.

\section{Clavatipollenites sp. 2}

Text-fig. 23a-c

Description and remarks. The material comprises a single clump of many pollen grains (not shown) that are all of the same kind. Pollen grains are monocolpate, almost circular in equatorial outline, about $16 \mu \mathrm{m}$ in diameter, and semitectate-reticulate with a homobrochate reticulum (Text-fig. 23a-c). Lumina are irregular and up to about $1.5 \mu \mathrm{m}$ in diameter. Muri are ornamented with tiny verrucae arranged along the margins of the muri. Columellae are long and widely spaced (Text-fig. 23c). The aperture is narrow elongate without a distinct margin (Text-fig. 23a), but in most grains only the proximal surface is exposed (Text-fig. 23b).

Affinity and other occurrences. In their general shape, the nature of the pollen wall and aperture configuration, the pollen grains are similar to various dispersed pollen grains that are generally assigned to the genus Clavatipollenites and that are thought to be of probable chloranthoid affinity (see above).

\section{Clavatipollenites sp. 3 \\ Text-fig. $23 \mathrm{~d}-\mathrm{j}$}

Description and remarks. The material comprises two fragments of small tetrasporangiate stamens with pollen in situ (Text-fig. 23d, g). The grains are monoaperturate and almost spherical, about $18 \mu \mathrm{m}$ in diameter, semitectate-reticulate with a homobrochate reticulum (Text-fig. 23e, f, h-j). Lumina are irregular and up to about $1.7 \mu \mathrm{m}$ in diameter. Muri are ornamented with tiny verrucae arranged at the top of the muri or in irregular rows (Text-fig. 23f, j). Columellae are long and widely spaced (Text-fig. 23f, j). The aperture is irregular, rounded to triangular, poorly defined and covered by irregular exine elements that grade into the reticulum (Text-fig. 23e, f, h). Orbicules that occur in one of the specimens are small, spherical with a spiny surface and a small central depression (Text-fig. 23i).

Affinity and other occurrences. The nature of the reticulum and the supratectal ornamentation resembles that of other grains described here as chloranthoids. The grains are similar to the pollen of Clavatipollenites sp. 1 in their broader and rounded aperture, but the aperture is smaller, the grains are larger, and the reticulum is coarser.

\section{Order Magnoliales Juss. ex Bercht. et J.PresL, 1820 Incertae familiae}

\section{Genus Serialis E.M.FriIs, P.R.Crane} et K.R.Pedersen, 2019

\author{
Serialis antiqua E.M.FriIs, P.R.Crane \\ et K.R.Pedersen, 2019 \\ Text-fig. 24a, b
}

Description and remarks. Serialis antiqua includes monocarpellate fruits or fruiting units up to about $2 \mathrm{~mm}$ long that contain four to six anatropous and mesotestalendotestal seeds arranged in two rows along the ventral suture (Text-fig. 24a, b). The ovule vasculature is especially distinctive. The vascular bundle runs from the hilum to chalaza, but then extends further on the antiraphal side from the chalaza to the micropyle. Pollen grains observed on the decurrent stigma are semitectate-reticulate.

Affinity and other occurrences. Serialis antiqua is known only from the Torres Vedras locality 

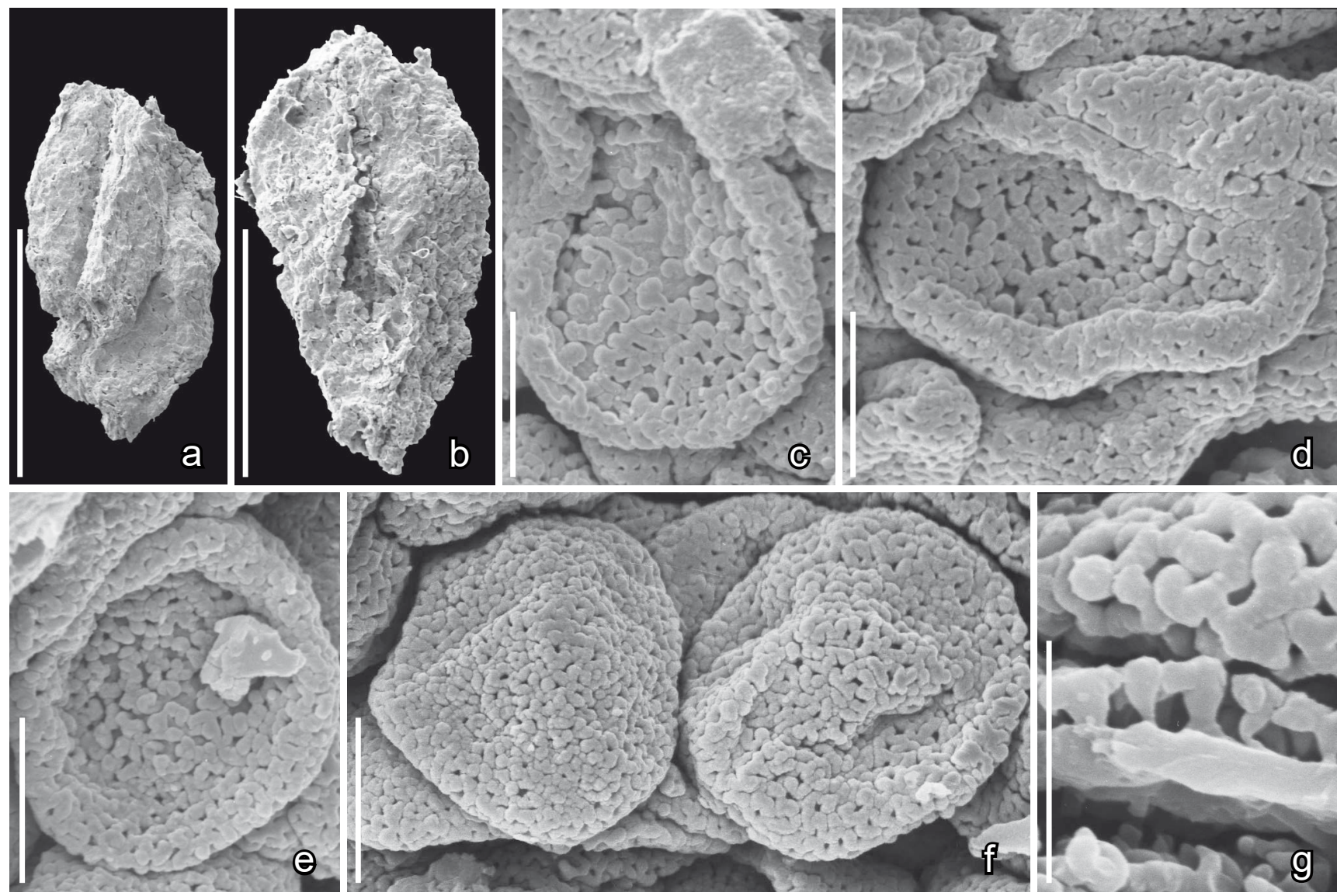

Text-fig. 22. Scanning electron microscope (SEM) images of fragmentary stamens (a, b) with in situ pollen of Clavatipollenites sp. 1 (c-g); Torres Vedras locality, Portugal. a, b) Fragmentary tetrasporangiate stamens; c-e) Distal view of pollen grains showing large, rounded aperture and the irregular verrucate aperture membrane; $f$ ) Proximal view of pollen grains showing dense reticulum; g) Section through the fractured pollen wall showing foot layer, columellae and muri with faint supratectal ornamentation. Specimens, TV44-S105013 (a, c, d), TV44-S105019 (b, e-g). Scale bars $300 \mu \mathrm{m}(\mathrm{a}, \mathrm{b}), 6 \mu \mathrm{m}$ (c-f), $3 \mu \mathrm{m}$ (g).

(Friis et al. 2019a), but other species of Serialis are widely distributed in the Early Cretaceous mesofossil floras that we have studied from Portugal. Features of seed organization and details of the seed coat, together with the distinctive ovule vasculature indicate that the fossils are related to extant Magnoliales. However, the fossils possess a combination of characters not known for any extant family of the order (Friis et al. 2019a).

\section{Serialis parva E.M.FriIs, P.R.CRANE et K.R.Pedersen, 2019 \\ Text-fig. 24c-e}

Description and remarks. Serialis parva is very similar to Serialis antiqua in organization and seed coat structure, but the fruits are smaller and there are only one or two seeds per fruit (Text-fig. 24c-e). The seed coat is mesotestal-endotestal with surface of mesotesta characterized by a jigsaw puzzle shaped pattern from the strongly undulate anticlinal walls of the mesotestal cells (Text-fig. 24d).

Affinity and other occurrences. Serialis parva is common in the Torres Vedras mesofossil flora. It also occurs at the Buarcos locality where it is rare (Friis et al. 2019a). Like other species of Serialis, the relationship of $S$. parva is with Magnoliales, but the character combination seen in the fossils is unknown in any extant family of the order (Friis et al. 2019a).

\section{Order Piperales Dumort., 1829 Incertae familiae}

\section{Genus Appomattoxia E.M.FriIS, K.R.PEDERSEN et P.R.Crane, 1995}

\section{Appomattoxia minuta E.M.FriIS, K.R.PEDERSEN et P.R.Crane sp. nov.}

\section{Text-fig. 25a-g}

H o l o t y p e. Designated here. S136786 (Torres Vedras sample 44; figured Text-fig. 25a, d, e).

Plant Fossil Names Registry Number. PFN000458 (for new species).

$\mathrm{P}$ a r a t y p e s . Designated here. S105022 (Torres Vedras sample 43); S136787, S136788, S148010 (Torres Vedras sample 44).

R e p o s i t o ry. Palaeobotanical Collections, Department of Palaeobiology, the Swedish Museum of Natural History, Stockholm, Sweden.

Ety mology. From Latin: minutus referring to the small size of the fruits. 

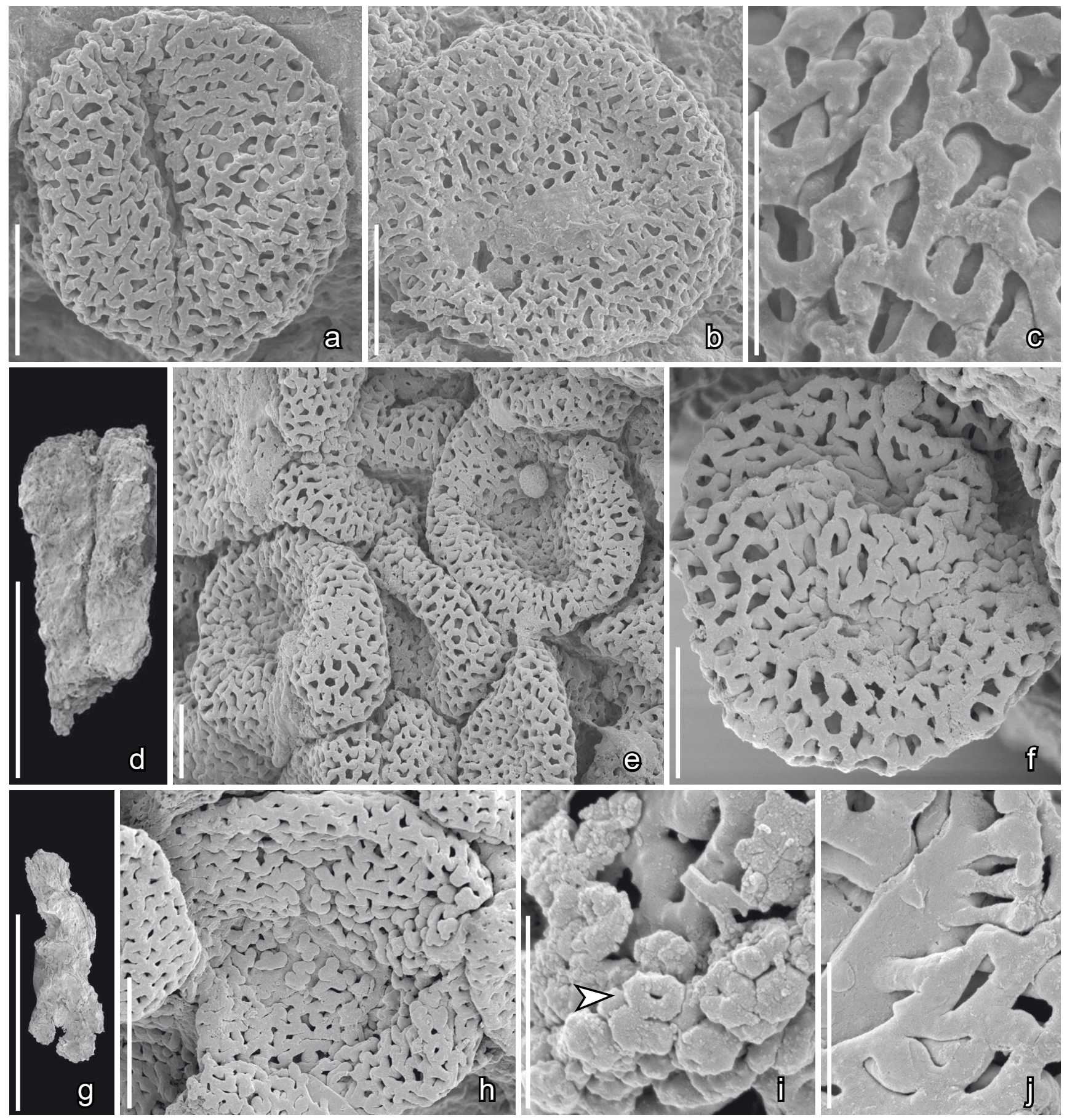

Text-fig. 23. Scanning electron microscope (SEM) images of Clavatipollenites sp. 2 (a-c) from a fragmentary stamen, and stamen fragments with in situ pollen of Clavatipollenites sp. 3 (d-j); Torres Vedras locality, Portugal. a, b) Distal (a) and proximal (b) view of pollen showing simple, elongate colpus on distal surface and semitectate-reticulate pollen wall; c) Detail of pollen wall showing muri with finely verrucate supratectal ornamentation and long scattered columellae; d) Fragment of tetrasporangiate stamen; e, f) Distal views of pollen from stamen fragment showing poorly defined aperture, coarse reticulum and long scattered columellae; g) Fragment of stamen; $h$ ) Distal view of pollen showing poorly defined aperture covered by irregular verrucae; i, j) Pollen wall showing rounded orbicules (i) and fractured pollen wall showing long scattered columellae (j). Specimens, TV43-S136728 (a-c), TV44-S149201 (d-f), TV44-S149220 (g-j). Scale bars $300 \mu \mathrm{m}$ (d, g), $6 \mu \mathrm{m}$ (a, b, e, f, h), $3 \mu \mathrm{m}$ (c), $1.5 \mu \mathrm{m}$ (i, j).

Type locality. Torres Vedras (NE of Forte de Forca; 3906' $\left.13^{\prime \prime} \mathrm{N}, 9^{\circ} 14^{\prime} 47^{\prime \prime} \mathrm{W}\right)$.

Type stratum and age. Lower member of the Almargem Formation; Early Cretaceous (late Barremianearly Aptian).

Specific diagnosis. As for the genus with the following additions: Fruits minute, narrowly elliptical to ovate in outline, borne on a short oblique stalk. Outer epidermal cells of fruit wall large, each bearing a central long and narrow trichome that is only slightly recurved at the tip. Stigma sessile, indistinct without trichomes. Pollen grains circular to elliptical in outline, monocolpate with short colpus. Exine tectate, irregularly verrucate and microechinate. 

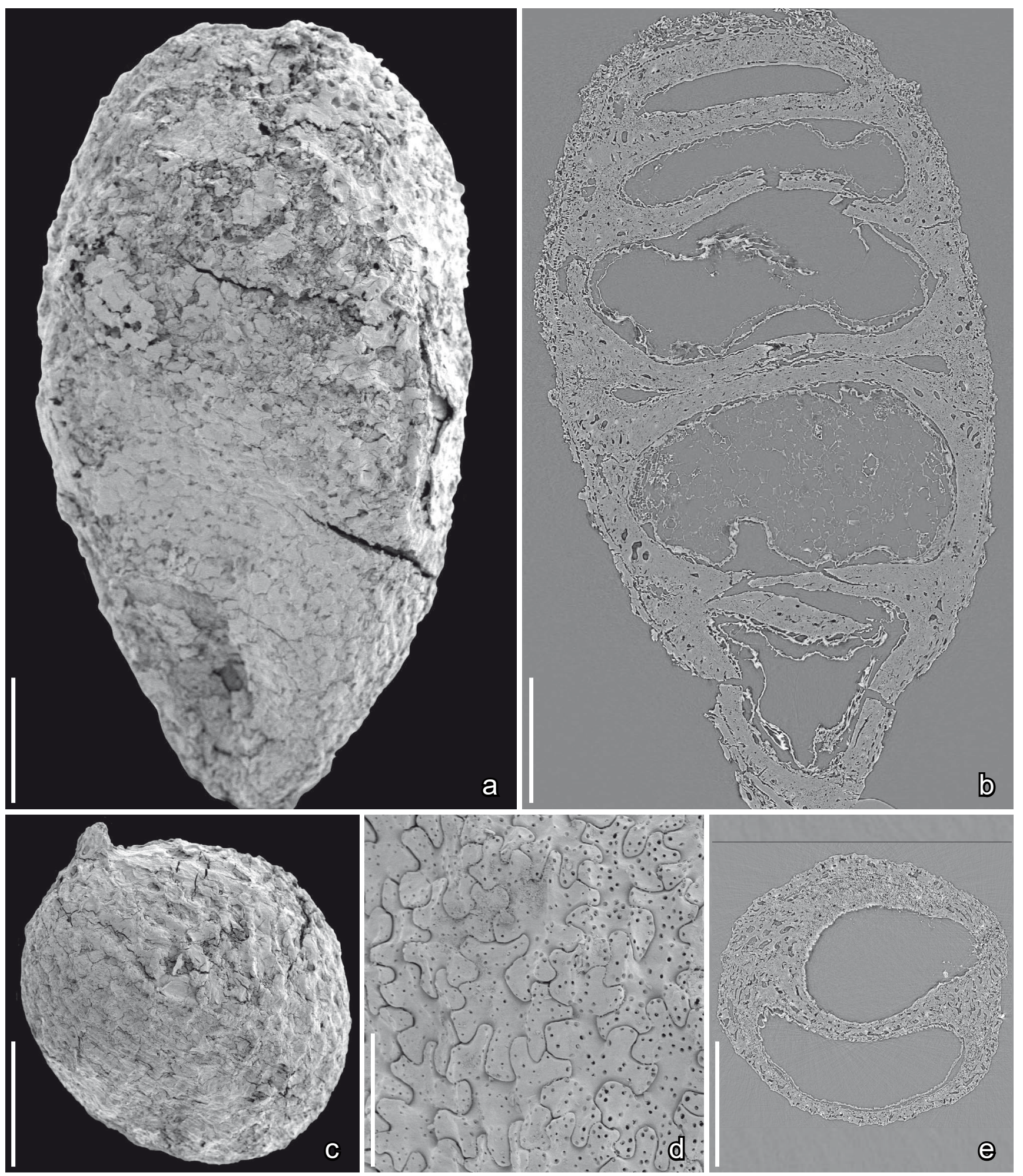

Text-fig. 24. Scanning electron microscope (SEM) images (a, c, d) and synchrotron radiation X-ray tomographic microscopy (SRXTM) images (b, e) of fruits and seeds of Serialis antiqua (a, b) and Serialis parva (c-e); Torres Vedras locality, Portugal. a, b) Serialis antiqua lateral view of fruit showing smooth partly abraded fruit wall (a) and longitudinal section (b, SRXTM orthoslice yz0862) showing six closely adhering seeds, some of which are mature with well-preserved nutritive tissue; c-e) Serialis parva lateral view of fruit showing faint ribs (c), finely pitted seed surface with undulate anticlinal walls of the exotestal cells (d), and transverse section showing two closely adhering seeds (SRXTM orthoslice xy0913, e). Specimens, TV43-S174480 (a, b), TV43-S170076 (c), TV43-S170079 (d), TV43-S174477 (e). Scale bars $300 \mu \mathrm{m}$ (a-c, e), $50 \mu \mathrm{m}$ (d).

Distinguishing features. Fruits of Appomattoxia minuta differ from those of the type species, A. ancistrophora E.M.FriIS, K.R.PEDERSEN et P.R.CRANE described from the Early Cretaceous Puddledock mesofossil flora of Virginia, USA (Friis et al. 1995), mainly in their much smaller size (fruits $0.45-0.75 \mathrm{~mm}$ long and 0.3 $0.4 \mathrm{~mm}$ wide compared to $0.6-2.0 \mathrm{~mm}$ long and $0.5-1.5 \mathrm{~mm}$ wide in A. ancistrophora). The trichomes on the fruit surface 
are also narrower and less robust than in A. ancistrophora. Further, the tips of the spines are only slightly recurved in A. minuta, but distinctly hook-shaped in A. ancistrophora. Pollen grains are closely similar to those of $A$. ancistrophora, but the colpus is shorter.

D i m e n s i o n s . Length of fruits: $0.45-0.75 \mathrm{~mm}$; width of fruits: $0.3-0.4 \mathrm{~mm}$. Length of spines: $0.15 \mathrm{~mm}$. Diameter of pollen grains: about $16 \mu \mathrm{m}$.

Description and remarks. Appomattoxia minuta is based on five isolated fruits. There is no information on how the fruits were attached to the plant. Each fruit is minute, elliptical to ovate in outline. All specimens are much compressed (Text-fig. 25a-c). In their general organization and shape the fruits are similar to Appomattoxia ancistrophora, and are also similar in having the thin fruit wall covered by densely arranged trichomes (Text-fig. 25a-c). The stigmatic area is indistinct, sessile and lacks trichomes. As in A. ancistrophora, the trichomes of the fruit wall are apparently unicellular, but they are only slightly recurved at the tips and the cuticle is thin. None of the specimens were macerated or studied using SRXTM.

Many pollen grains, all of the same kind, occur entangled in the trichomes on the surface of all the fruits (Text-fig. $25 \mathrm{~d}-\mathrm{g})$. The pollen is circular to elliptic in equatorial outline, about $16 \mu \mathrm{m}$ in diameter and monocolpate. The colpus is short, about $6 \mu \mathrm{m}$ long and does not reach the equator. The grains are tectate with an irregular rugulate surface covered by closely spaced and solitary microechinae (Text-fig. $25 \mathrm{~d}-\mathrm{g})$. The colpus membrane is covered by small verrucae (Text-fig. 25f, g).

Affinity and other occurrences. The pollen grains associated with Appomattoxia minuta are closely similar to those occurring in situ in dithecate and tetrasporangiate anthers that are assigned to Goczania rugosa. Appomattoxia minuta and Goczania rugosa may belong to the same natural species (see below).

Pollen grains found in situ in staminate flowers of Pseudoasterophyllites cretaceus FEISTM. ex VELEN. from the Cenomanian of the Czech Republic show some similarities to pollen grains associated with Appomattoxia, but differ in having a much shorter and broader colpus. Further, pollen grains of Pseudoasterophyllites cretaceus have a tectum with a mixed columellate and granular infratectal layer (Kvaček et al. 2016) in contrast to the granular infratectal layer documented by TEM for Appomattoxia ancistrophora from the Puddledock mesofossil flora (Friis et al. 1995). Fruits of Pseudoasterophyllites cretaceus also differ from those of Appomattoxia in several respects, including the lack of trichomes and the presence of stomata on the fruit wall, and in having a short decurrent stigma (Kvaček et al. 2016).

A piperalean affinity was suggested for Appomattoxia by Friis et al. (1995), based on combined features of the fruits, seeds and pollen. Monocolpate, tectate and microechinate grains that are especially similarity to grains of Appomattoxia are known in extant Piper L. (Grayum 1992). Extant Peperomia RuIZ et PAV. has inaperturate pollen, but also has pollen grains resembling those associated with $A$. ancistrophora and $A$. minuta in their supratectal ornamentation and rugose pollen wall (e.g. Halbritter and Buchner 2016).
Doyle and Endress (2014) suggested a relationship to Chloranthaceae rather than Piperales for Appomattoxia, and emphasized the presence of supratectal microechinate (spinules) on the tectum as a feature shared between the pollen associated with Appomattoxia and pollen of Chloranthaceae. However, supratectal microechinae occur in many different angiosperms and a fully tectate pollen wall is not known for any extant or fossil chloranthoid taxon. All extant and fossil chloranthoids have a semitectate-reticulate pollen wall, while all extant Piperales are characterized by tectate pollen. Securely resolving the putative chloranthoid versus piperalean affinities of Appomattoxia will require additional information on the parent plants that produced these fruits, but the difficulties of assigning these fossils to an extant group are illustrative of the broader problem of determining the relationships of Early Cretaceous fossils in the face of massive extinction in the early phases of angiosperm diversification (Friis et al. 2019a).

\section{Genus Appofructus E.M.FriIs, K.R.PEDERSEN et P.R.Crane gen. nov.}

Ty p e. Designated here. Appofructus nudus E.M.Fris, P.R.Crane et K.R.Pedersen gen. et sp. nov.

Plant Fossil Names Registry Number. PFN000459 (for new genus).

Etymology. From the part name Appo in Appomattoxia and fructus (Latin for fruit) to indicate close relationship between the two genera.

D i a g n o s is . Small, isolated unilocular and one-seeded fruits. Fruits rounded with an oblique stalk at the base of the ventral margin. Stigma sessile, rounded. Fruit wall thin with smooth outer surface lacking trichomes. Pollen grains monocolpate, oblate, circular to elliptical in equatorial outline, tectate, almost smooth with microechinate surface sculpturing.

D ist inguishing features. Fruits of Appofructus are similar to fruits of Appomattoxia in general form and organization, but differ mainly in the lack of trichomes on the fruit wall. The tectate, monocolpate pollen associated with Appofructus is also very similar to the pollen associated with Appomattoxia. Several, small fruits or fruiting units comparable to Appofructus in gross morphology are known from Cretaceous mesofossil floras. However, most are follicular and contain several seeds; for example, as in the follicles of Paisia pantoporata E.M.FrIIS, M.M.MENDES et K.R.PedERsen described from the Catefica mesofossil flora (Friis et al. 2018e). Except for Appomattoxia, none of these early angiosperm fruiting units are associated with monocolpate, microechinate pollen.

\section{Appofructus nudus E.M.Fris, K.R.Pedersen et P.R.Crane sp. nov. Text-fig. 26a, b, e-g}

H o l o t y p e. Designated here. S148143 (Torres Vedras sample 44; figured Text-fig. 26a).

Plant Fossil Names Registry Number. PFN000460 (for new species). 

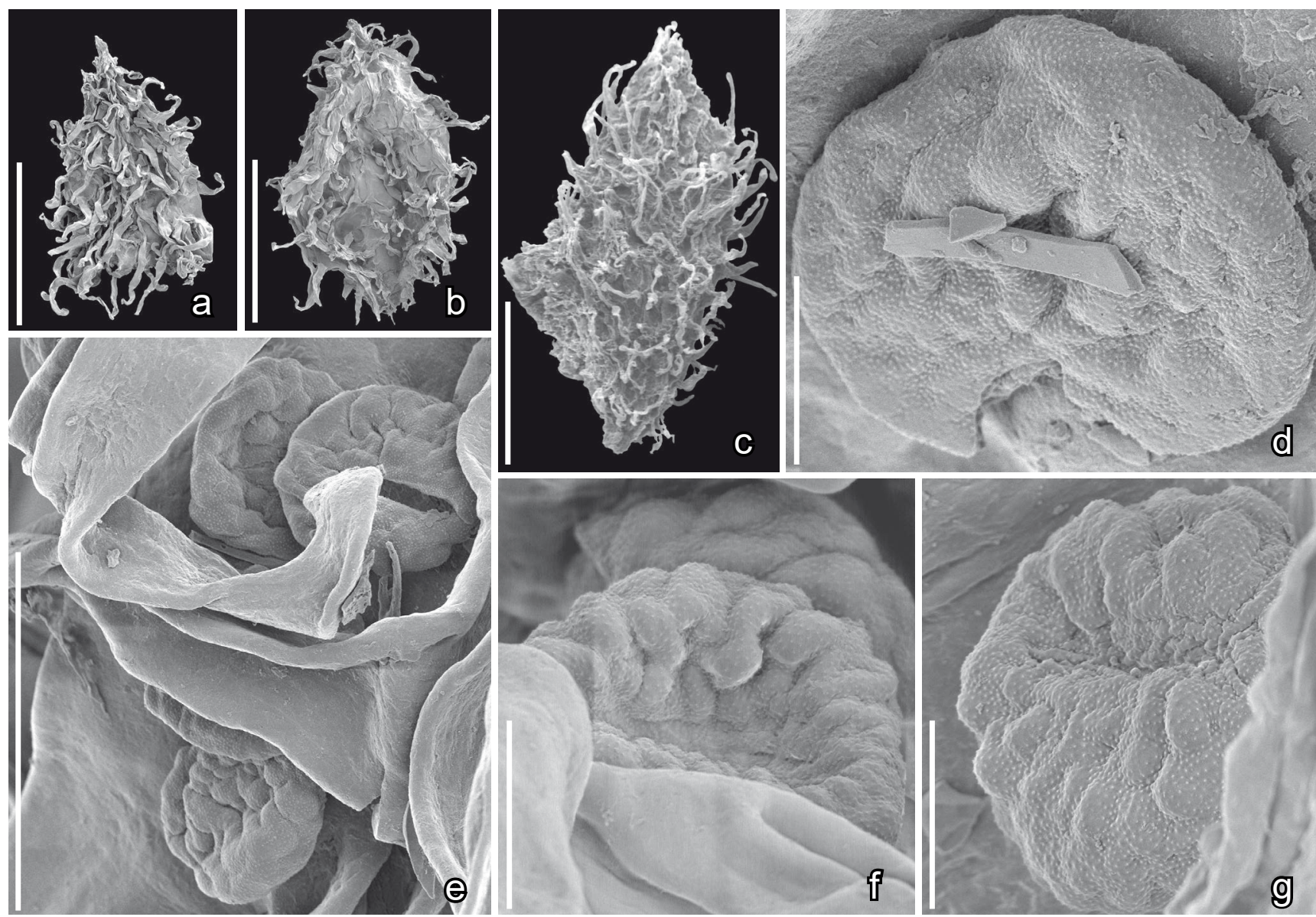

Text-fig. 25. Scanning electron microscope (SEM) images of Appomattoxia minuta sp. nov. fruits and associated monocolpate pollen grains; Torres Vedras locality, Portugal. a-c) Lateral view of fruits (a, holotype) covered with hooked hairs showing the apical stigmatic area; $\mathbf{d - g}$ ) Pollen grains from the fruits in (a) and (b) showing short monocolpate aperture, granular aperture membrane and microechinate tectum. Specimens, TV44-S136786 (holotype; a, d, e), TV44-S136787 (b, f, g), TV43-S105022 (c). Scale bars $300 \mu \mathrm{m}(\mathrm{a}-\mathrm{c}), 30 \mu \mathrm{m}(\mathrm{e}), 6 \mu \mathrm{m}(\mathrm{d}, \mathrm{f}, \mathrm{g})$.

P a r atypes. Designated here. S136687, S136693; S148007-S148009, S148141 (Torres Vedras sample 44).

Re p o s i t ory. Palaeobotanical Collections, Department of Palaeobiology, the Swedish Museum of Natural History, Stockholm, Sweden.

E ty m o log y. From Latin: nudus for naked referring to the smooth surface of the fruit without trichomes.

Type locality. Torres Vedras (NE of Forte de Forca; 39 $06^{\prime} 13^{\prime \prime} \mathrm{N}, 9^{\circ} 14^{\prime} 47^{\prime \prime} \mathrm{W}$ ).

Type stratum and age. Lower member of the Almargem Formation; Early Cretaceous (late Barremianearly Aptian).

Di a g no s is. As for the genus.

D i m e n s i o n s . Length of fruits: $0.85-0.95 \mathrm{~mm}$; width of fruits: $0.48 \mathrm{~mm}$. Diameter of pollen grains: about $12-$ $14 \mu \mathrm{m}$.

Description and remarks. Appofructus nudus is based on seven isolated fruits. Whether the fruits are fruiting units from an apocarpous fruit, or are derived from a monocarpellate gynoecium, is unknown. The fruits are compressed in various orientations (lateral in Text-fig. 26a, dorsiventrally in Text-fig. 26b) and typically have a very crumpled surface. The fruits are unilocular, one-seeded with an oblique stalk at the base of the ventral margin (Text-fig. 26a, b). The stigma is sessile and rounded (Text-fig. 26e). The fruit wall is thin with a smooth, crumpled outer surface that lacks trichomes. Pollen grains attached to the stigma are oblate, circular to elliptical in equatorial outline, and monocolpate. The exine is tectate with a weakly rugulate surface and microechinate surface sculpturing (Text-fig. $26 \mathrm{e}-\mathrm{f}$ ) resembling that of pollen of Goczania (see below).

Affinity and other occurrences. Fruits of Appofructus nudus are currently known only from Torres Vedras where they co-occur with Appomattoxia minuta in one sample (Torres Vedras sample 44). The pollen grains associated with Appofructus are of the Goczania-type (see below), and are very similar to the grains associated with Appomattoxia. Appofructus and Appomattoxia are probably closely related and their systematic affinity is probably with the Piperales (see above).

\section{Appofructus sp.}

Text-fig. 26c, d

Description and remarks. Appofructus sp. is based on a single isolated fruit that has an oblique stalk at the base of the ventral margin (Text-fig. 26c). The fruit 
is about $0.55 \mathrm{~mm}$ long and $0.4 \mathrm{~mm}$ wide, crescent-shaped and laterally flattened. The stigma is sessile and indistinct. As in Appofructus nudus the fruit wall is thin with smooth outer surface that lacks trichomes. However, the fruit wall is not crumpled and appears more rigid that in A. nudus. A single Goczania-type pollen grain was observed on the fruit surface. The grain is preserved with the proximal face upwards and there is no information on the pollen aperture. The grain is oblate, circular in equatorial outline and about $12.5 \mu \mathrm{m}$ in equatorial diameter (Text-fig. 26d). The exine is tectate with microechinate surface sculpturing. The surface sculpturing appears slightly coarser than in the pollen grains associated with Appofructus nudus, and the microechinae are more widely spaced, but otherwise the pollen grain appears very similar to those associated with $A$. nudus (see above).

Affinity and other occurrences. Appofructus sp. is very similar to fruits of Appofructus nudus and is probably related to extant Piperales (see above).

\section{Genus Goczania E.M.Fris, P.R.Crane et K.R.PEDERSEN gen. nov.}

Ty p e. Designated here. Goczania rugosa E.M.FriIs, P.R.Crane et K.R.Pedersen gen. et sp. nov.

Plant Fossil Names Registry Number. PFN000461 (for new genus).

E ty m o lo g y. In honor of the Hungarian palynologist Ferenc Góczan in recognition of his important contribution to Cretaceous palynology.

Diagnosis. Stamens short, broad, dithecate and tetrasporangiate. Inner surface of anther wall with densely arranged orbicules. Orbicules small, spherical with microechinate surface. Pollen small, oblate, circular to elliptical in equatorial outline, monocolpate with a simple colpus. Exine tectate with a smooth to slightly rugulate surface. Supratectal ornamentation microechinate, composed of solitary microechinae. Infratectal layer granular. Colpus margin irregular, distinct.

Comments on the genus. Pollen grains of Goczania are very similar to the pollen associated with fruits of Appomattoxia and Appofructus. In the original discussion of Appomattoxia (Friis et al. 1995) we noted the similarity
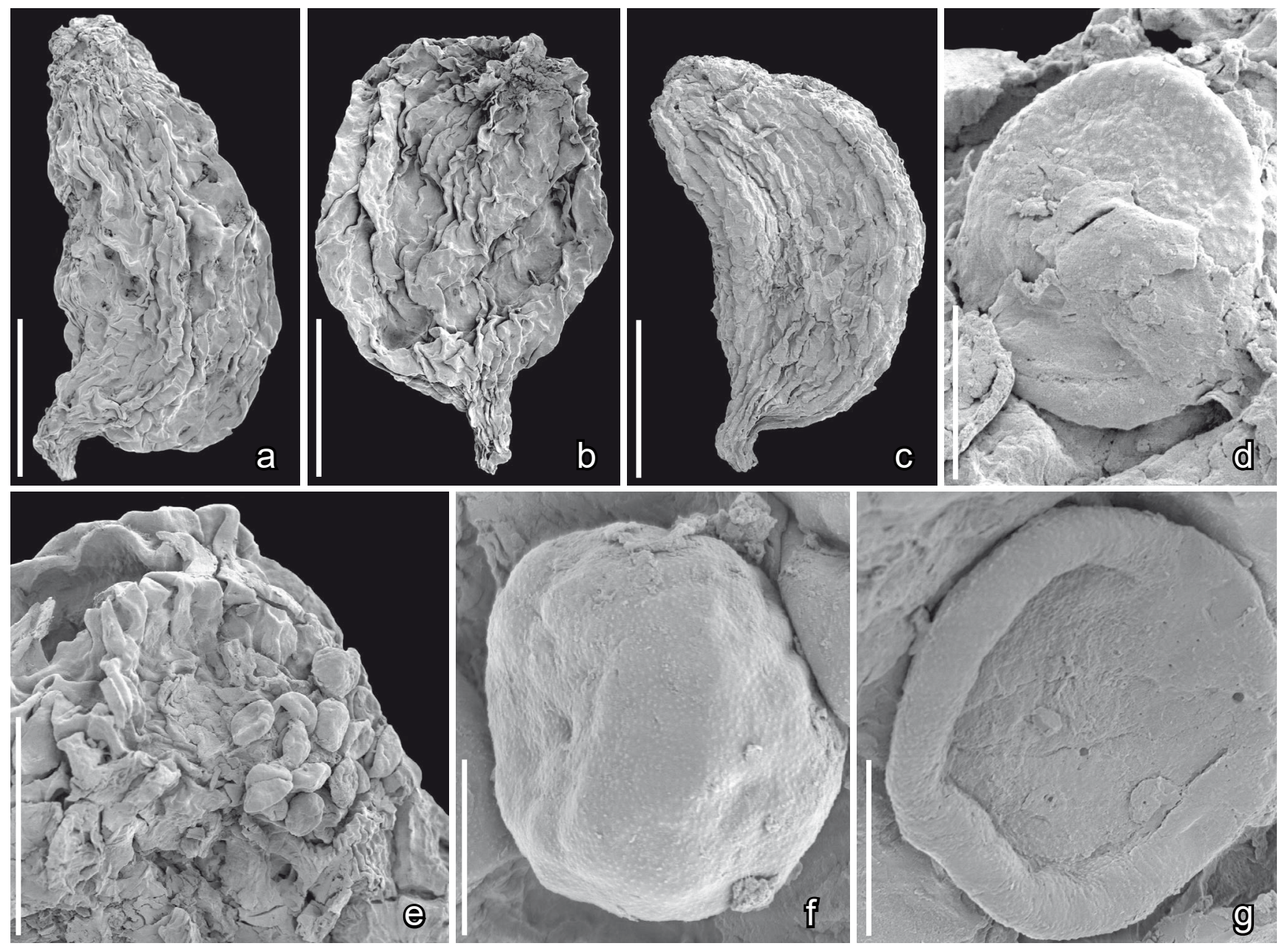

Text-fig. 26. Scanning electron microscope (SEM) images of fruits of Appofructus gen. nov. and associated pollen grains; Torres Vedras locality, Portugal. a, b) Appofructus nudus gen. et sp. nov., lateral views of fruits (holotype figured in a) showing the ribbed surface, the poorly defined apical stigmatic area and short stalk; c, d) Appofructus sp. lateral view of fruit showing the absence of hooked hairs, the apical stigmatic area, the short stalk and pollen grain from the fruit surface (d); e-g) Appofructus nudus gen. et sp. nov., individual monocolpate pollen grains (f, g) from the group of pollen grains on the stigmatic surface (e). Specimens, TV44-S148143 (holotype; a); TV44-S148007 (b), TV38-S174610 (c, d), TV44-S148141 (e, f), TV44-S136687 (g). Scale bars $300 \mu$ m (a-c), $60 \mu \mathrm{m}$ (e), $6 \mu \mathrm{m}$ (d, f, g). 
of the pollen associated with Appomattoxia to dispersed pollen grains of Transitoripollis Góczan et JuHÁsz (Góczan and Juhász 1984) and Tucanopollis Regali (Regali 1989). However, Tucanopollis is clearly distinguished from the pollen grains of Goczania by its ring-shaped aperture and thicker pollen wall. The type species of Transitoripollis, $T$. anulisulcatus GócZAN et JuHÁsz, also differs from Goczaniatype grains in having an annular aperture (Góczán and Juhász 1984). SEM of the exine also shows that grains of Transitoripollis have microechinae that are often merged together in groups, while in Goczania microechinae on the tectum surface are solitary. Dispersed pollen grains with solitary microechinae and a rugulate surface similar to Goczania rugosa have been described from the HauterivianAptian of southern England and assigned to the informal biorecord Hauterivian-cactisulcus and CfB Hauteriviancactisulcus (Hughes 1994). Grains described as CfA Barremian-ring (Hughes 1994) may also be related, but have a round, rather than elliptical aperture. Similar grains are also reported from the early Aptian-early Albian of Egypt as Fulltec-Solid (Penny 1991).

\section{Goczania rugosa E.M.Fris, P.R.CRANE et K.R.Pedersen sp. nov. Text-fig. $27 \mathrm{a}-\mathrm{f}$}

H o l o ty p e. Designated here. S136688 (Torres Vedras sample 44; figured Text-fig. 27a, c-f).

Plant Fossil Names Registry Number. PFN000462 (for new species).

P a r a t y p e s . Designated here. S148129 (Torres Vedras 43), S136664 (Torres Vedras sample 44).

R e p o s i t ory. Palaeobotanical Collections, Department of Palaeobiology, the Swedish Museum of Natural History, Stockholm, Sweden.

E t y m o lo g y. From Latin: rugosus referring to rugose surface of the pollen grains.

Type locality. Torres Vedras (NE of Forte de Forca; 3906'13" N, 9०14'47" W).

Type stratum and age. Lower member of the Almargem Formation; Early Cretaceous (late Barremianearly Aptian).

Diagnosis. As for the genus with the following additions: Equatorial outline of pollen almost circular. Tectum weakly rugulate. Microechinae evenly distributed over the tectum.

D imensions. Length of anther: about $0.45 \mathrm{~mm}$; width of anther: $0.45 \mathrm{~mm}$. Diameter of pollen grains: $14.5-$ $15.5 \mu \mathrm{m}$.

Description and remarks. Goczania rugosa is based on three well-preserved anthers with pollen grains in situ. The anthers are short, broad, dithecate and tetrasporangiate (Text-fig. 27a, b). The outer surface of the anther wall has short trichomes close to the apex. The inner surface of anther wall is covered by small, spherical, densely spaced orbicules with a microechinate surface. Orbicules are also scattered over the surface of the pollen grains (Text-fig. 27f).
The pollen grains are oblate, circular to elliptical in equatorial outline, about $14.5-15.5 \mu \mathrm{m}$ in diameter and monocolpate (Text-fig. 27c-f). The colpus is short with an irregular and indistinct margin, although in occasional abraded grains the colpus margin is sharply outlined in the foot layer. The colpus membrane is verrucate to rugulate. The exine is tectate with the tectum covered with densely spaced microechinate. The microechinae occur only singly, and do not merge together with their neighbors in groups.

Pollen grains of Goczania rugosa are closely similar to those associated with the fruits of Appomattoxia minuta and it is possible that these fruits, and the Goczania rugosa stamens with their in situ pollen grains, were produced by the same kind of plants. Currently, however, both the fruits and the stamens only occur isolated and secure attribution of the two organs to the same plant will require additional evidence.

Affinity and other occurrences. Like Appomattoxia minuta and A. ancistrophora, as well as Appofructus nudus and Appofructus sp., Goczania rugosa is probably related to extant Piperales (see above). Goczania rugosa is also represented in the Catefica mesofossil flora by a well-preserved stamen with pollen in situ.

\section{Goczania inaequalis E.M.FrIIS, P.R.CrANe et K.R.PEDERSEN sp. nov. Text-fig. 28a-1}

H o l o t y p e. Designated here. S137919 (Torres Vedras sample 44; figured Text-fig. 28a-f).

Plant Fossil Names Registry Number. PFN000463 (for new species).

P a r a types. Designated here. S136768, S148011, S174557 (Torres Vedras sample 44).

R e p o s it o ry. Palaeobotanical Collections, Department of Palaeobiology, the Swedish Museum of Natural History, Stockholm, Sweden.

Et y m o logy. From Latin: inaequalis referring to the uneven distribution of the microechinae.

Type locality. Torres Vedras (NE of Forte de Forca; 3906'13" N, 9०14'47" W).

Type stratum and age. Lower member of the Almargem Formation; Early Cretaceous (late Barremianearly Aptian).

Diagnosis. As for the genus with the following additions: Equatorial outline of pollen circular to transversely elliptical. Tectum microperforate and microechinate, not rugulate. Perforations minute and scattered. Microechinae confined to the proximal surface and bordering the colpus on the distal surface; otherwise the distal face and equatorial region psilate.

Distinguishing features. The species is distinguished from Goczania rugosa by the psilate, nonrugulate, surface of the pollen and the uneven distribution of the supratectal ornamentation. Goczania inaequalis is distinguished from G. punctatus by the less pronounced perforations in the tectum. 
D i m e n s i o n s . Equatorial diameter of pollen grains: $11-12 \mu \mathrm{m}$.

Description and remarks. Goczania inaequalis is based on four anther fragments with in situ pollen grains (Text-fig. 28a, g) as well as isolated pollen grains found in coprolites (Text-fig. 48c, e). The inner surface of the anther wall is covered by densely spaced orbicules (Text-fig. 28b, c, f). Orbicules are also scattered over the surface of the pollen grains (Text-fig. 281). The orbicules are small, spherical and with a surface ornamentation of microechinate sculpturing (Text-fig. 28c).

The pollen grains are small, circular to transversely elliptical in equatorial outline, and about $11-12 \mu \mathrm{m}$ in equatorial diameter (Text-fig. 28d-f, h, j-1). The colpus is long, reaching almost to the equator. In grains that are transversely elliptical, the colpus is oriented perpendicular to the longest axis of the grain (Text-fig. 28d, k, 1). The colpus margin is distinct with a slightly irregular outline. The pollen wall is tectate with a supratectal ornamentation of solitary microechinae on the proximal surface and also bordering the colpus. Microechinae are absent from the distal face between the colpus margin and the equator where the tectum is psilate (Text-fig. $28 \mathrm{~d}-\mathrm{-e}, \mathrm{h}, \mathrm{j}-\mathrm{l}$ ). As seen in several broken grains the infratectal layer is thin and granular (Textfig. 28i).
Affinity and other occurrences. Goczania inaequalis, like Appomattoxia minuta, Appomattoxia ancistrophora, Appofructus nudus and Appofructus sp., as well as Goczania rugosa, is probably related to extant Piperales (see above).

Goczania inaequalis is currently known only from the Torres Vedras mesofossil flora. Pollen grains reported as Tucanopollis cf. crispopollenites from the early-late Aptian of Algarve, Portugal (Heimhofer et al. 2007) may be conspecific with Goczania inaequalis, but details of the tectum ornamentation/perforation are not clear from the LM illustrations and at this resolution it may be difficult to distinguish between $G$. inaequalis and G. punctata (see below).

\section{Goczania punctata E.M.Fris, P.R.CrANE et K.R.PEDERSEN sp. nov. \\ Text-fig. 29a-c}

H o l o t y p e. Designated here. S148024 (Torres Vedras sample 44; figured Text-fig. 29a-c).

Plant Fossil Names Registry Number. PFN000464 (for new species).

Re p o s i tory. Palaeobotanical Collections, Department of Palaeobiology, the Swedish Museum of Natural History, Stockholm, Sweden.
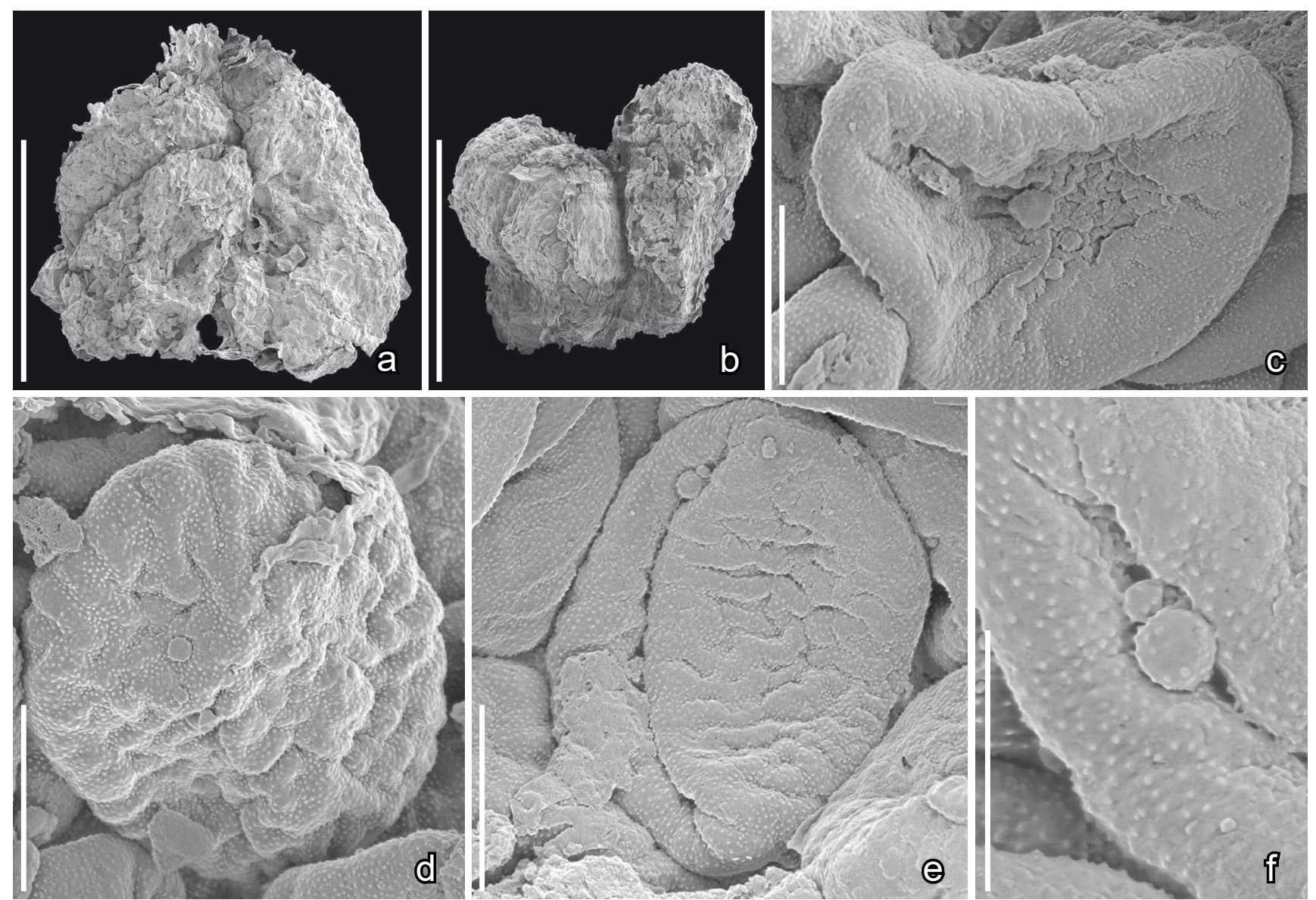

Text-fig. 27. Scanning electron microscope (SEM) images of monocolpate pollen grains of Goczania rugosa gen. et sp. nov. in situ in dithecate, tetrasporangiate stamens; Torres Vedras locality, Portugal. a, b) Stamens in apical view (holotype a) showing the paired pollen sacs; c) Pollen grain from stamen fragment in (b) showing short aperture and rugulate-microechinate surface; d-f) Pollen grains from stamen fragment in (a) showing a folded distal aperture and rugulate-microechinate surface; note the orbicules of different sizes. Specimens, TV44-S136688 (holotype; a, c-f), TV44-S136664 (b). Scale bars $300 \mu \mathrm{m}$ (a,b), $6 \mu \mathrm{m}$ (c-e), $3 \mu \mathrm{m}$ (f). 

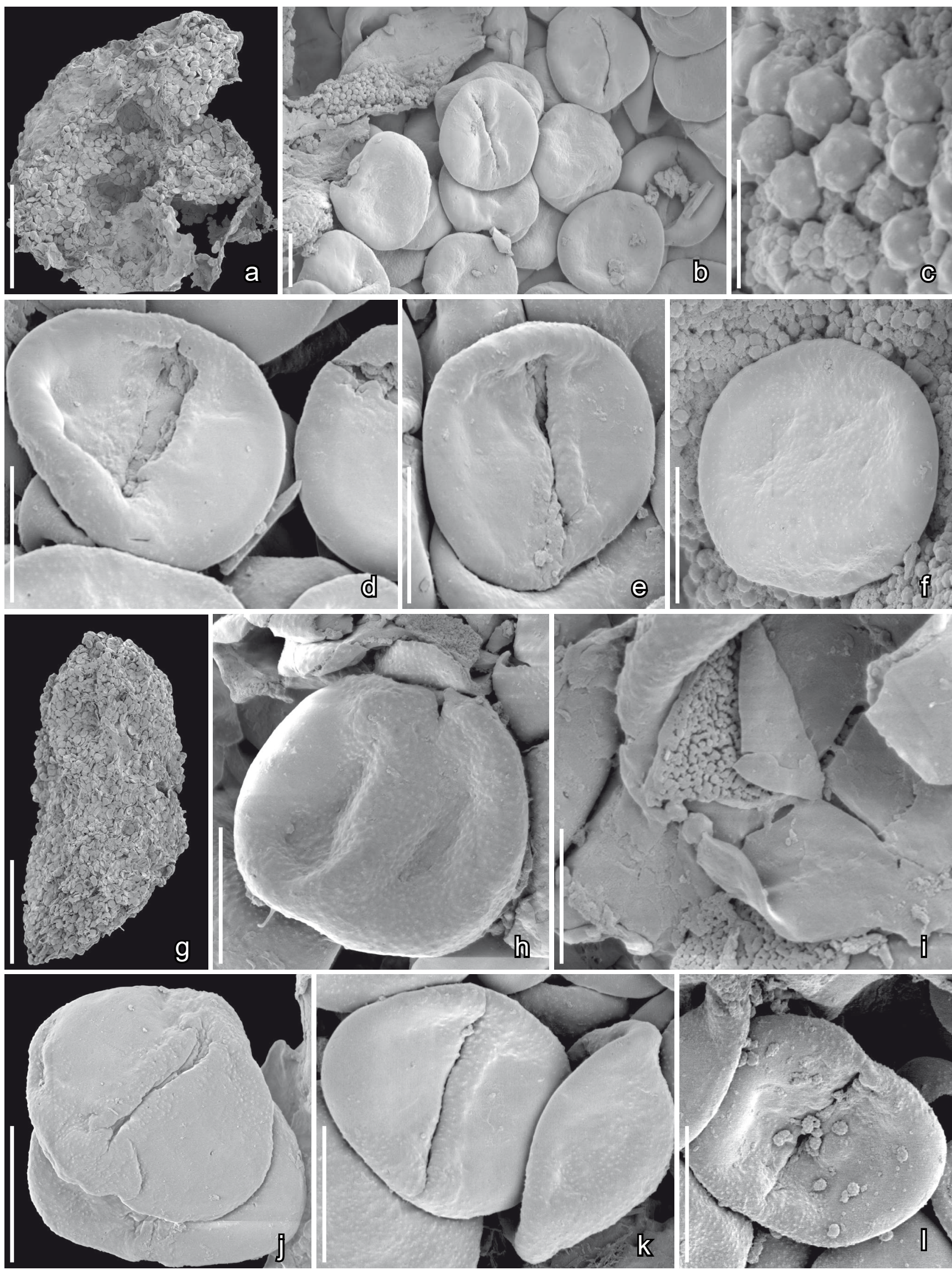

Text-fig. 28. Scanning electron microscope (SEM) images of monocolpate pollen of Goczania inaequalis sp. nov.; Torres Vedras locality, Portugal. a) Holotype; stamen fragment that yielded the pollen in (b-f, k); b) Group of pollen grains showing distal and proximal surfaces and inner surface of anther wall with densely spaced orbicules; c) Inner surface of anther wall showing small, spherical orbicules with microechinate sculpturing; $d, e, j-l)$ Pollen grains in distal and equatorial view (k) showing the long colpus with an irregular margin flanked by narrow bands of poorly differentiated microechinate; note that colpus is aligned perpendicular to the longest axes in elliptical grains and that the pollen wall is almost psilate around the equator and in the distal 
Etymology. From Latin: punctatus referring to punctate pollen wall.

Type locality. Torres Vedras (NE of Forte de Forca; 39॰06' $13^{\prime \prime} \mathrm{N}, 9^{\circ} 14^{\prime} 47^{\prime \prime} \mathrm{W}$ ).

Type stratum and age. Lower member of the Almargem Formation; Early Cretaceous (late Barremianearly Aptian).

Diagnosis. As for the genus with the following additions: Equatorial outline of pollen circular to transversely elliptical. Microechinae on proximal surface and bordering the colpus; distal face, except along the colpus, punctatefoveolate.

D ist inguishing feat ures. Pollen of Goczania punctata is closely similar to that of $G$. inaequalis, but differs in the slightly larger grains that have a distinctly perforate tectum on their distal face. Pollen of Goczania punctata is also distinguished from that of G. rugosa in having a smoother surface and in having the microechinae restricted mainly to the proximal face of the grains.

D i m e n s i o n s. Diameter of pollen grains: 13-14 $\mu \mathrm{m}$.

Description and remarks. Goczania punctata is based on a single anther fragment (Text-fig. 29a) with pollen in situ. Orbicules on the inner surface of the anther and among the pollen grains are rare. They are small, spherical and with a microechinate surface.

Pollen grains are small, circular to slightly transversely elliptical in equatorial outline, about 13-14 $\mu \mathrm{m}$ in equatorial diameter (Text-fig. 29b, c) and monocolpate. The colpus is long, reaching almost to the equator (Text-fig. 29b, c). The colpus margin is distinct (Text-fig. 29b). The exine is tectate with a supratectal ornamentation of solitary microechinae on the proximal surface and bordering the colpus. On the distal surface, beyond the colpus margin, the tectum is psilatepunctate-foveolate (Text-fig. 29b, c).

Affinity and other occurrences. Goczania punctata is currently known only from the Torres Vedras mesofossil flora. Like Appomattoxia minuta, Appomattoxia ancistrophora, Appofructus nudus and Appofructus sp., along with Goczania rugosa and Goczania inaequalis, Goczania punctata is probably related to extant Piperales (see above).

\section{Genus Dejaxia E.M.FriIs, P.R.Crane et K.R.Pedersen gen. nov.}

Type. Designated here. Dejaxia brevicolpites E.M.FriIs, P.R.Crane et K.R.Pedersen gen. et sp. nov.

Plant Fossil Names Registry Number. PFN000465 (for new genus).

Etymology. In honor of the French palynologist Jean Dejax in recognition of his important contributions to Cretaceous palynology.
D i a g n o s i s . Pollen small, almost spherical, equatorial outline circular, monocolpate. Colpus short. Colpus margin distinct, slightly irregular. Pollen wall slightly undulating/ rugulate, tectate, psilate-punctate-foveolate. Colpus membrane finely verrucate. Orbicules small, spherical with an irregular surface pattern.

Comments on the genus. Pollen grains of Dejaxia are closely similar to those of Goczania that are found in isolated stamens and anther fragments, and are also associated with fruits of Appomattoxia and Appofructus. However, pollen grains of Dejaxia differ from those of Goczania in having a shorter colpus, a finely verrucate colpus membrane, and lacking microechinate supratectal sculpturing. The orbicules of Dejaxia also differ from those of Goczania in lacking a microechinate surface.

\section{Dejaxia brevicolpites E.M.Fris, P.R.Crane et K.R.Pedersen sp. nov. Text-fig. 30a-h}

H o l o t y p e. Designated here. S137909 (Torres Vedras sample 44; figured Text-fig. 30a-h).

Plant Fossil Names Registry Number. PFN000466 (for new species).

Re p o s i t ory. Palaeobotanical Collections, Department of Palaeobiology, the Swedish Museum of Natural History, Stockholm, Sweden.

E t y m o l o g y. From Latin: brevis for short, and colpus, referring to the short colpus.

Type locality. Torres Vedras (NE of Forte de Forca; 39 $06^{\prime} 13^{\prime \prime} \mathrm{N}, 9^{\circ} 14^{\prime} 47^{\prime \prime} \mathrm{W}$ ).

Type stratum and age. Lower member of the Almargem Formation; Early Cretaceous (late Barremianearly Aptian).

Di a $\mathrm{g}$ o o is. As for the genus.

D i m e n s i o n s. Equatorial diameter of pollen grains: about $16 \mu \mathrm{m}$.

Description and remarks. Dejaxia brevicolpites is based on a pollen clump, probably an abraded pollen sac, containing many pollen grains of the same kind (Text-fig. 30a). The pollen grains are small, almost spherical with a circular equatorial outline, and monocolpate (Text-fig. 30b, $\mathrm{c}-\mathrm{h}$ ). The exine is tectate, psilate-punctate-foveolate with a slightly undulating/rugulate surface in which the rugulae are associated with depressions around the scattered perforations (Text-fig. 30b, h). The colpus is short, about $6 \mu \mathrm{m}$ long and much shorter than the equatorial diameter. The colpus margin is distinct but slightly irregular. The colpus membrane is finely verrucate (Text-fig. 30d-e). Abundant small, spherical orbicules with an irregular surface occur abundantly on the surface of the pollen grains (Text-fig. 30b-e, g, h). 
Affinity and other occurrences. Dejaxia brevicolpites is currently known only from the Torres Vedras mesofossil flora. Dejaxia brevicolpites, like Appomattoxia minuta, Appomattoxia ancistrophora, Appofructus nudus and Appofructus sp., as well as the species of Goczania, is probably related to extant Piperales (see above).

\section{Genus Burgeria E.M.FriIS, P.R.Crane et K.R.PEDERSEN gen. nov.}

Ty pe. Designated here. Burgeria striata E.M.Fris, P.R.Crane et K.R.PEDERSEN gen. et sp. nov.

Plant Fossil Names Registry Number. PFN000467 (for new genus).
Etymology. In honor of the American botanist William C. Burger in recognition of his contributions to the study of angiosperm evolution.

D i a g n o s is. Pollen grains of medium size, broadly ellipsoidal to subcircular in equatorial outline, monocolpate. Colpus in fully developed grains almost as long as longest axis, broad; colpus in smaller (aborted?) grains about half the length of the longest axis. Exine tectate-punctate and columellate with short columellae and a thin foot layer. Surface of tectum finely striate. Orbicules spherical, punctate with finely striate surface.

Comments on the genus. The pollen grains of Burgeria are among the largest angiosperm grains observed
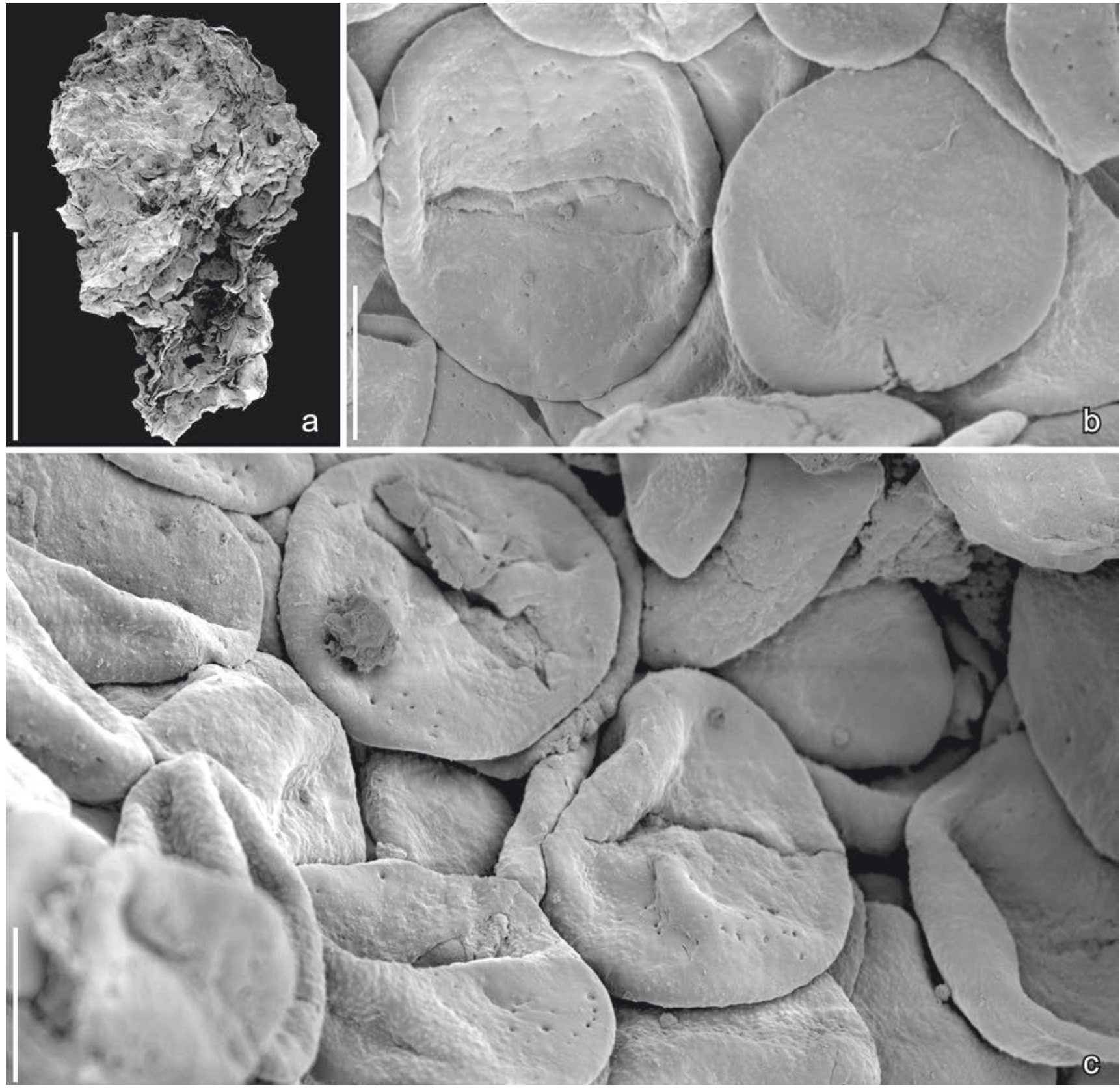

Text-fig. 29. Scanning electron microscope (SEM) images of monocolpate pollen of Goczania punctata sp. nov.; Torres Vedras locality, Portugal. a-c) Holotype; anther fragment (a) with group of pollen grains showing the distal face (b, c) with clearly delimited colpus, the almost psilate tectum with occasional small perforations, and poorly differentiated microechinae on the proximal face (b). Specimen, TV44-S148024 (holotype). Scale bars $300 \mu \mathrm{m}$ (a), $6 \mu \mathrm{m}$ (b, c). 
in the Torres Vedras flora. In their tectate-perforate exine and long colpus, pollen of Burgeria is similar to grains of Lethomasites fossulatus J.V.WARD, J.A.Doyle et HotTON described from the Early Cretaceous Potomac Group (Ward et al. 1989). However, L. fossulatus is much larger $(92-127 \mu \mathrm{m})$, the exine stratification is granular rather than columellate, and the grains have larger perforations (foveolae/ fossulae) that expose the infratectal granules. Resolution of the SEM images of L. fossulatus is good, but it is not clear whether there are fine striations between the perforations as in Burgeria. Pollen grains of Burgeria striata are also similar to pollen of Foveomonocolpites ravnii E.SchranK described from the Early Cretaceous of Israel (Schrank 2017). Like Burgeria, pollen of $F$. ravnii has a tectate-columellate and finely perforate exine, but the grains are larger $(42-69 \mu \mathrm{m})$ and the surface between the perforations is smooth.

Among extant angiosperms comparable monocolpate, tectate-perforate and finely striate pollen grains have been described for the two species of Gymnotheca DeCnE., $G$. chinensis DeCNE. and G. involucrata C.PEI, in the piperalean family Saururaceae (Smith and Stockey 2007). Pollen of Gymnotheca is also similar to that of Burgeria in exine stratification with short columellae and a thin foot layer. Gymnotheca pollen also has a long, broad colpus with a granular colpus membrane similar to that of Burgeria. However, pollen grains of Saururaceae are tiny compared to those of Burgeria (Smith and Stockey 2007, Grímsson et al. 2017). Although probably systematically close to the family Saururaceae, fossil Burgeria pollen cannot be included securely in any extant genus or within the family. Burgeria is assigned here broadly to the Piperales. The presence of orbicules also supports a probable relationship to Piperales (Gonzáles et al. 2001).

\section{Burgeria striata E.M.FriIS, P.R.CRANE et K.R.Pedersen sp. nov. Text-figs 31a-h, 32a-e}

H o l o t y p e. Designated here. S149216 (Torres Vedras sample 44; figured Text-fig. 31a-h).

Plant Fossil Names Registry Number. PFN000468 (for new species).

P a r a t y p e s . Designated here. S174620 (Torres Vedras sample 39), S136676 (Torres Vedras sample 44).

R e p o s i t o ry. Palaeobotanical Collections, Department of Palaeobiology, the Swedish Museum of Natural History, Stockholm, Sweden.

E ty mology. From Latin: striatus to emphasize the finely striate pollen wall.

Type locality. Torres Vedras (NE of Forte de Forca; 39 $06^{\prime} 13^{\prime \prime} \mathrm{N}, 9^{\circ} 14^{\prime} 47^{\prime \prime} \mathrm{W}$ ).

Type stratum and age. Lower member of the Almargem Formation; Early Cretaceous (late Barremianearly Aptian).

D i a gnosis. As for the genus.

Dimensions. Pollen grains: 28-29 $\mu \mathrm{m}$ long (smaller, abnormal? grains about $18 \mu \mathrm{m}$ long); 22-25 $\mu \mathrm{m}$ wide (smaller, abnormal? grains about $15 \mu \mathrm{m}$ wide).
Description and remarks. Burgeria striata is based on three pollen clumps, probably fragments of stamens, with numerous pollen grains in situ (Text-figs 31a, 32a). The holotype (S149216) was first thought to be a coprolite (Friis et al. 2010a), but the pollen grains are all of the same kind and the fragment includes remains of the pollen wall with the characteristic striate orbicules. In this fragment, the pollen grains are all of the same size and all are apparently fully developed (Text-fig. 31b-e). In one of the paratypes (S174620), larger, apparently fully developed grains co-occur with smaller, perhaps aborted grains (Textfig. 32c-e). The larger pollen grains are of medium size, broadly ellipsoidal in equatorial outline and monocolpate (Text-figs 31b-e, 32c, d). Smaller grains are subcircular in equatorial outline. The exine is about $0.8 \mu \mathrm{m}$ thick, tectatepunctate and columellate with short columellae and a thin foot layer (Text-fig. 31f). The exine surface is finely striate (Text-figs $31 \mathrm{f}-\mathrm{g}, 32 \mathrm{~b}$ ). In the specimen that has pollen of two sizes the surface of the smaller grains is sometimes rugulate, perhaps indicating that the wall is not fully expanded (Textfig. 32c-e). In the larger (fully developed) grains the colpus is broad and almost as long as the longest axis of the grains (Text-figs 31b, d, e, 32c, d). In smaller (aborted?) grains the colpus is short, and extends for about half the length of the longest axis (Text-fig. 32c, e). Orbicules occur scattered on the surface and between the grains (Text-figs 31b-e, h, $32 \mathrm{c}-\mathrm{e})$. Orbicules are spherical, and range in size from about $1-3 \mu \mathrm{m}$. They are similar to the pollen grains in their perforated wall and finely striate surface (Text-fig. 31h).

Affinity and other occurrences. Burgeria striata has so far only been recorded from the Torres Vedras locality. The affinities of $B$. striata are uncertain, but among extant plants are most likely with Saururaceae among Piperales (see comments on the genus).

\section{Order Piperales?}

\section{Tectate pollen grains from coprolite Text-fig. 33a-d}

Remarks. Several large tectate-punctate and apparently monocolpate pollen grains occur in a coprolite/ pollen clump (specimen S137906) together with a wide range of other pollen types. The pollen grains are almost circular in polar view, about $26-30 \mu \mathrm{m}$ in diameter, and with a short, apparently circular aperture (Text-fig. 33a, b). The exine surface is smooth with densely spaced perforations of various sizes (Text-fig. 33a-c). One specimen seen from the proximal side has a somewhat rugulate surface (Textfig. 33d), and it is unknown whether this grain belongs to a separate taxon.

Affinity and other occurrences. Pollen resembling these tectate grains have not been observed in other Early Cretaceous floras from Portugal and their systematic affinity is uncertain. Although the grains show certain similarities with other tectate grains from the Torres Vedras locality that are thought to be of piperalean affinity (see above), they differ in several features, especially in the shorter and broader aperture, and they may not be related. These pollen grains are also much larger than the grains associated with Appomattoxia and Appofructus, as well as 

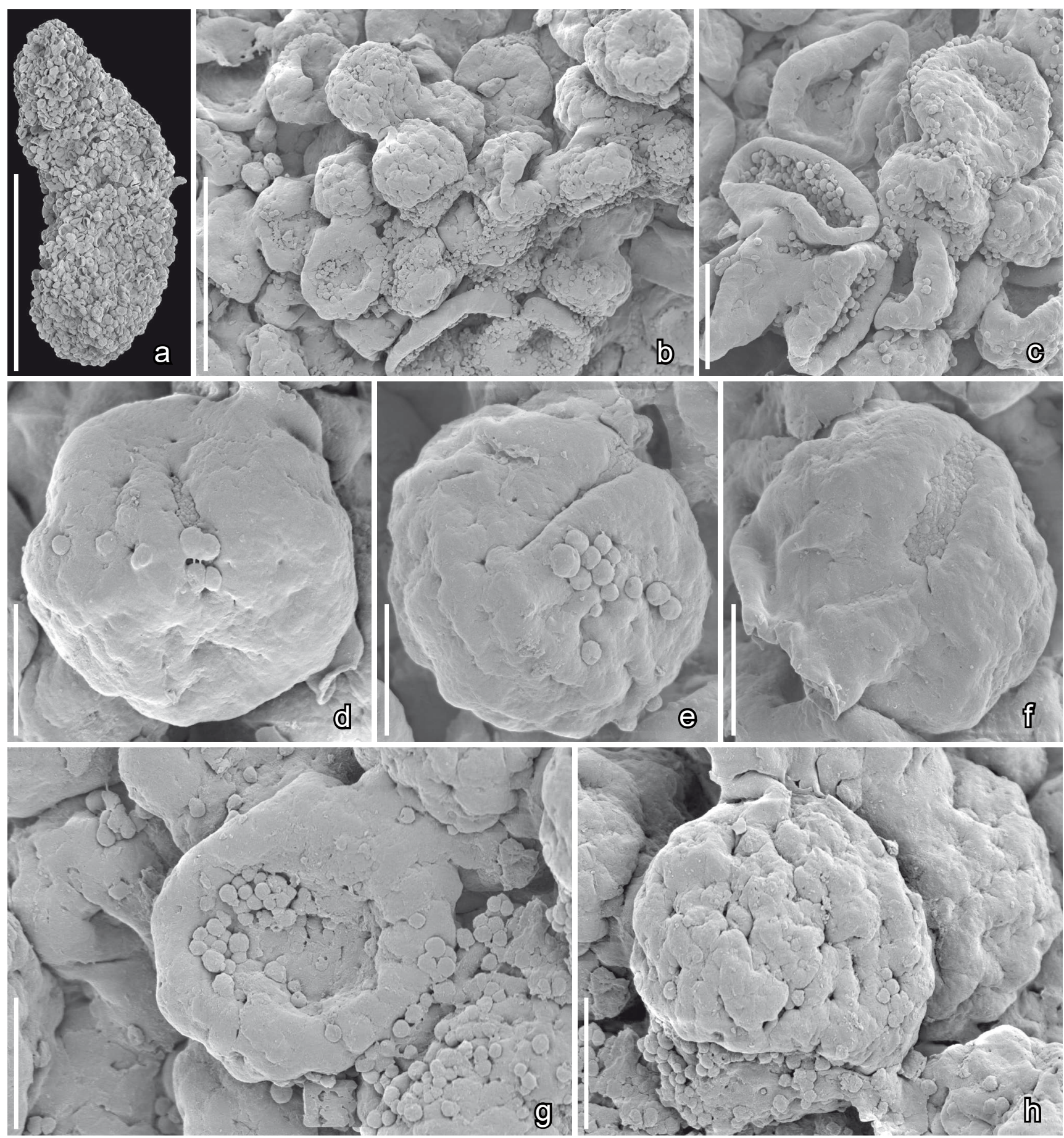

Text-fig. 30. Scanning electron microscope (SEM) images of monocolpate pollen of Dejaxia brevicolpites gen. et sp. nov. from a pollen clump; Torres Vedras locality, Portugal. a) Holotype; pollen clump (possible single pollen sac) that yielded the pollen in this Textfigure; b, c) Group of almost spherical pollen grains showing the irregularly undulating psilate tectum and abundant orbicules; d-g) Pollen grains showing the short colpi with a granular aperture membrane $(d, f)$ and the irregularly undulating psilate tectum with scattered small perforations; note abundant orbicules (g); h) Pollen grain in proximal view showing the irregularly undulating psilate tectum resulting from the depressions around the perforations in the pollen wall. Specimen, TV44-S137909 (holotype). Scale bars $300 \mu \mathrm{m}$ (a), $30 \mu \mathrm{m}$ (b), $12 \mu \mathrm{m}$ (c), $6 \mu \mathrm{m}$ (d-h).

putatively related grains assigned to Dejaxia and Goczania, and also lack the fine spines on the tectum surface. The pollen grains in the coprolite also differ from the the pollen of Burgeria, mainly in the configuration of the aperture and different exine surface.

In their general morphology, size and apparently thick pollen wall these tectate pollen grains are more similar to grains of Tucanopollis described from the Barremian- early Aptian of Brazil (Regali 1989), but lack the echinate supratectal ornamentation and the characteristic verrucate colpus membrane of Tucanopollis pollen. The Torres Vedras grains are also similar to dispersed pollen described from the Early Cretaceous of southern England as CfA Barremian-ring, but the Torres Vedras grains are larger and lack the fine spines on the tectum surface (Hughes 1994). The pollen grains from the coprolite are also similar to grains assigned to the extinct 

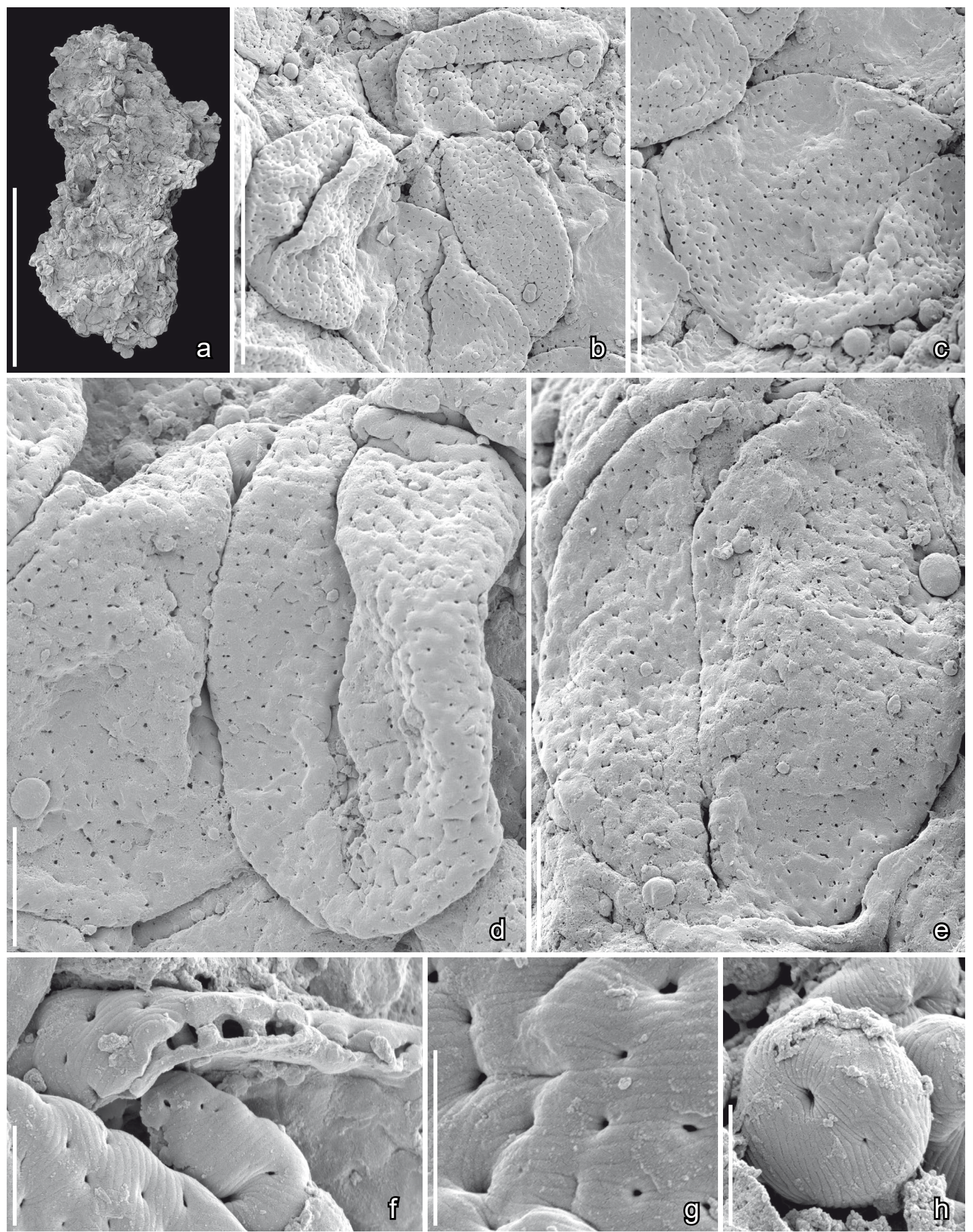

Text-fig. 31. Scanning electron microscope (SEM) images of monocolpate pollen of Burgeria striata gen. et sp. nov. from a pollen clump; Torres Vedras locality, Portugal. a) Holotype; pollen clump that yielded the pollen in this Text-figure; b) Pollen grains showing the distal colpus and the undulating tectum perforated by scattered punctae; c-e) Equatorial (c) and distal views (d, e) of pollen grains showing the long distal colpus with granular ornamentation and the undulating tectum perforated by scattered punctae; f) Detail of section through pollen wall showing thick tectum with fine striate ornamentation, perforated by punctae and supported by short stout columellae attached to the thin foot layer; g-h) Surface of tectum (g) and orbicule (h) showing fine striate ornamentation. Specimen, TV44-S149216 (holotype). Scale bars $300 \mu \mathrm{m}$ (a), $30 \mu \mathrm{m}$ (b), $6 \mu \mathrm{m}$ (c-e), $1.5 \mu \mathrm{m}$ (f-h). 

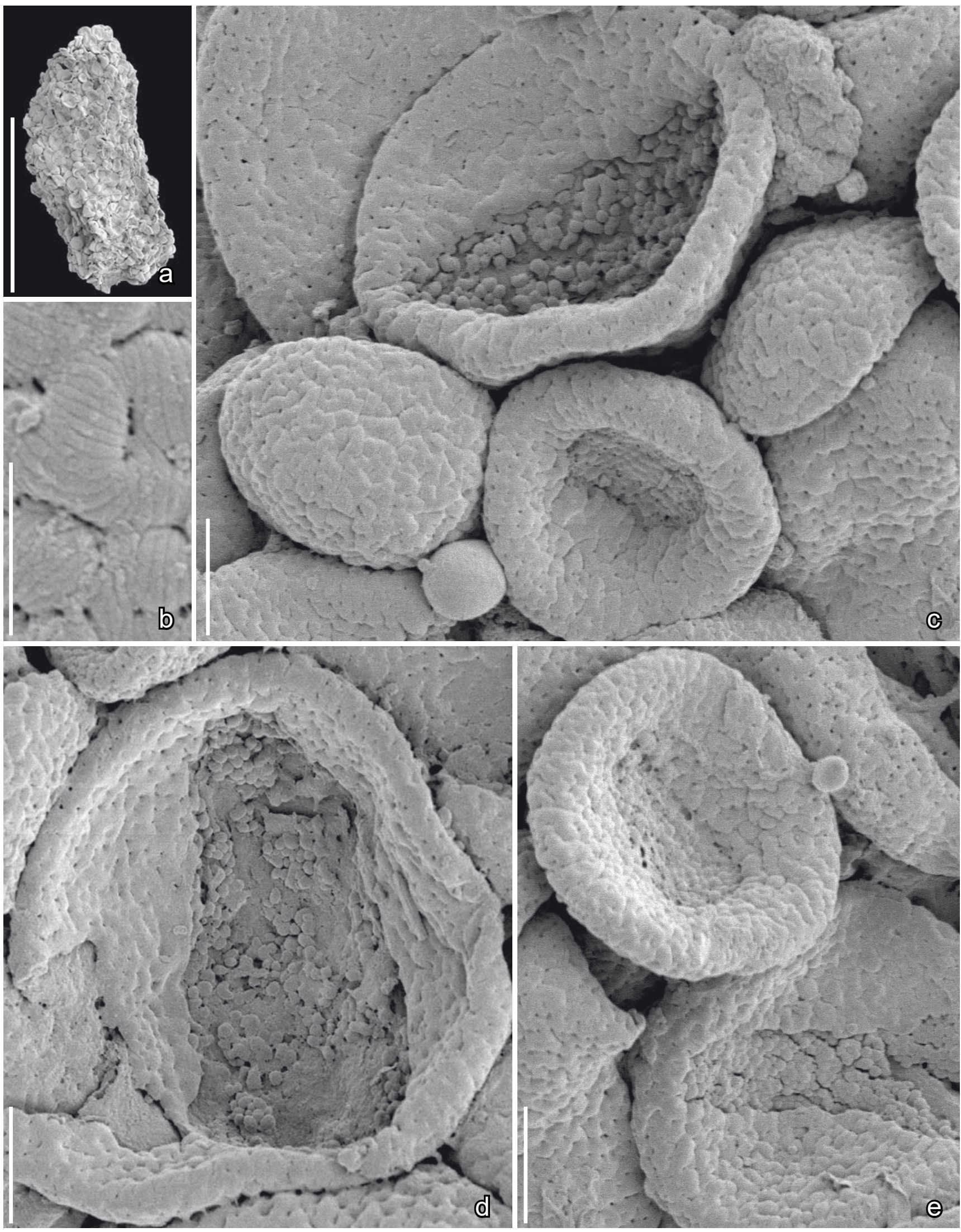

Text-fig. 32. Scanning electron microscope (SEM) images of monocolpate pollen of Burgeria striata gen. et sp. nov. from a pollen clump; Torres Vedras locality, Portugal. a) Pollen clump that yielded the pollen in this Text-figure; b) Pollen surface showing fine striate ornamentation; c-e) Pollen grains showing broad distal colpus with distinct granular ornamentation and the undulating tectum perforated by scattered punctae; note the very different sizes of pollen grains in the same pollen clump. Specimen, TV44-S174620. Scale bars $300 \mu \mathrm{m}$ (a), $6 \mu \mathrm{m}$ (c-e), $1.5 \mu \mathrm{m}$ (b). 
genus Crassipollis GóczAn et JuHÁsz in the very thick tectate pollen wall. However, all six species of Crassipollis described by Góczan and Juhász (1984) from the Albian of Hungary, including the type species, are characterized by a long, straight colpus that is sometimes broader at each end. This contrasts with the more rounded aperture seen in specimens from the Torres Vedras coprolite. Pollen grains assigned to Crassipollis from the Barremian of Spain (Villanueva-Amadoz et al. 2015) are more similar to the Torres Vedras grains in their aperture configuration, but the Spanish grains are smaller.

\section{Monocotyledons}

R e m a r k s. Remains of monocotyledons are rare in the Torres Vedras mesofossil flora. One taxon briefly described and illustrated as a potential monocot pollen (fossil coprolite with zona-aperturate pollen; Friis et al. 2004) is from the Puddledock flora, Virginia, USA (Puddledock sample 149), and not from the Torres Vedras flora as previously reported.

Family Araceae Juss., 1789

\author{
Genus Mayoa E.M.FriIs, K.R.PEDERSEN \\ et P.R.Crane, 2004
}

\section{Mayoa portugallica E.M.FrIIS, K.R.PEDERSEN et P.R.Crane, 2004 \\ Text-fig. 34}

Description and remarks.Mayoa portugallica was established based on a large group of pollen found in a poorly preserved floral fragment (Text-fig. 34a) that was studied using SEM and TEM (Friis et al. 2004). The pollen grains are inaperturate and distinctly striate (polyplicate) with two sets of ribs and grooves that are almost perpendicular to each other (Text-fig. 34b-d).

Affinity and other occurrences. Based on the unusual crossed arrangement of the ribs and grooves, and the structure of the pollen wall, the relationships of Mayoa were interpreted to be with extant Araceae (Friis et al. 2004), potentially within the family and close to Spathiphyllum SCOTT and Holochlamys ENGL. of the Spathiphylleae. To our knowledge this assignment has not been challenged and the presence of fossil aroids in the Early Cretaceous is now well established (Friis et al. 2004, Sender et al. 2018). The pollen wall of Mayoa is unlike that of superficially similar ephedroid grains.

A single grain of Mayoa portugallica was reported from the Casal do Borracho palynoflora collected close the Torres Vedras mesofossil site, apparently in the same part of the Almargem Formation (Mendes et al. 2018), but otherwise Mayoa has not been reported from other mesofossil floras in Portugal or elsewhere.

\section{Order Alismatales?}

\section{Genus Pennicarpus E.M.Fris, K.R.Pedersen et P.R.Crane, 2000}

\section{Pennicarpus sp. \\ Text-fig. 35a}

Description and remarks. Three fruits of Pennicarpus have been recovered from the Torres Vedras mesofossil flora. The fruits are closely similar to fruits of Pennicarpus tenuis E.M.Fris, K.R.PEDERSEN et P.R.Crane described from the Vale de Água mesofossil flora (Friis et al. 2000b), but are longer and narrower, about $0.75 \mathrm{~mm}$ long and $0.27 \mathrm{~mm}$ wide $(0.6 \mathrm{~mm}$ long and $0.4 \mathrm{~mm}$ wide in $P$. tenuis). The fruit wall is thin with faint longitudinal ridges and encloses a single seed (Text-fig. 35a). It is possible that the specimens from Torres Vedras represent a new species, but due to their poor preservation, we assign the fruits to Pennicarpus only at the generic level.

Affinity and other occurrences. Pennicarpus was first described from the Vale de Água mesofossil flora (Friis et al. 2000b) and is also known from the Buarcos mesofossil flora. Pennicarpus fruits are linked to the stamens of Pennistemon by the pollen in situ within the stamens and the consistent occurrence of Pennipollis pollen on the surfaces of Pennicarpus fruits. The Pennistemon plant is thought to be an early monocotyledon (see below for Pennipollis).

\section{Genus Pennipollis E.M.Fris, K.R.Pedersen et P.R.Crane, 2000}

\section{Pennipollis sp.}

Text-fig. 35b-d

Description and remarks. Pollen grains of Pennipollis sp. occur in a pollen clump that is probably a stamen fragment (Text-fig. 35b), and also in a coprolite together with several different kinds of pollen grains. Pollen grains are spherical, about $18 \mu \mathrm{m}$ in diameter and monocolpate. The exine is semitectate-reticulate and acolumellate, with scattered supratectal spinules. The spinules have pointed tips and are arranged in one or two rows along the margin of the muri (Text-fig. 35c, d). Lumina are of various sizes, but are generally large and up to about $3 \mu \mathrm{m}$ long.

Affinity and other occurrences. The pollen grains of Pennipollis sp. from Torres Vedras are closely similar to grains found in situ in isolated stamens and in a fragment of a staminate inflorescence of Pennistemon portugallicus E.M.FrIIS, K.R.PEDERSEN et P.R.CRANE described from the Vale de Água mesofossil flora (Friis et al. 2000b). However, the grains of Pennistemon portugallicus are smaller, the lumina are generally larger and the supratectal elements are blunt and more densely distributed. In supratectal ornamentation the grains from Torres Vedras are more similar to grains of Pennipollis peroreticulatus (G. J.BRENNER) E.M.FriIs, K.R.PEDERSEN et P.R.CRANE described from the Albian of Oklahoma by Walker and Walker (1984) as Retimonocolpites peroreticulatus (G.J.BRENNER) J.A.DoylE. Whether these grains are similar to the holotype from the Potomac Group sediments is uncertain as Brenner's original material was studied only using LM.

Fossil remains of the Pennistemon plant (Pennistemon E.M.Fris, K.R.Pedersen et P.R.Crane, Pennicarpus and Pennipollis) are relatively well known, and although rare at the Torres Vedras locality, are common in the Vale de Água and Buarcos mesofossil floras (Friis et al. 2000b). In the Torres Vedras mesofossil assemblage remains of the Pennistemon plant include only three fruits of Pennicarpus 


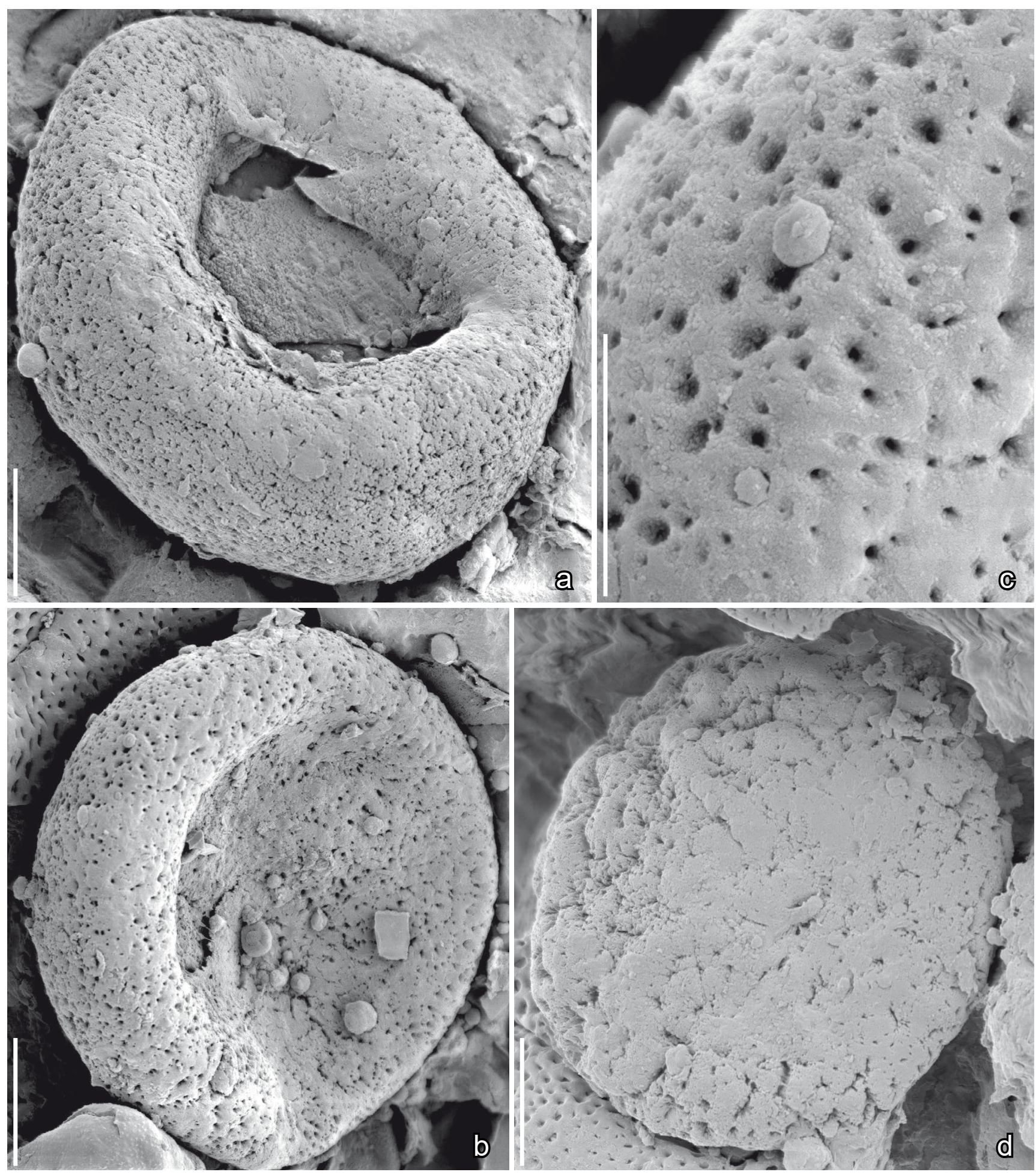

Text-fig. 33. Scanning electron microscope (SEM) images of tectate-punctate pollen from probable coprolite (not shown); Torres Vedras locality, Portugal. a-c) Monocolpate pollen grains in distal view (a, b) showing poorly defined aperture and punctate surface of the tectum (c) of the grain in (b); d) Pollen grain showing slightly rugulate surface of tectum; aperture not visible. Specimens, TV44-S137906-06 (a-c), TV44-S137906-08 (d). Scale bars $6 \mu \mathrm{m}$ (a, b, d), $3 \mu \mathrm{m}$ (c).

and pollen grains of Pennipollis from two pollen clumps and a coprolite. Pollen of Pennipollis is also reported from coastal sections in Portugal (Heimhofer et al. 2007) ranging from the early Aptian to the middle Albian.

Based on the more abundant and better preserved specimens from the Vale de Água locality we suggested an affinity of the Pennistemon plant to monocotyledons, and particularly to Araceae, although the fossils could not be assigned to any existing taxon (Friis et al. 2000b). Based on pollen alone Doyle and Hotton (1991) suggested affinity with Chloranthaceae, and a chloranthaceous affinity has been repeatedly advanced based on phylogenetic analyses that have also included features from the fossil fruits and stamens (e.g. Doyle and Endress 2014). However, the pollen grains of Pennipollis are fundamentally different from the pollen of all extant and securely analyzed extinct chloranthoid 

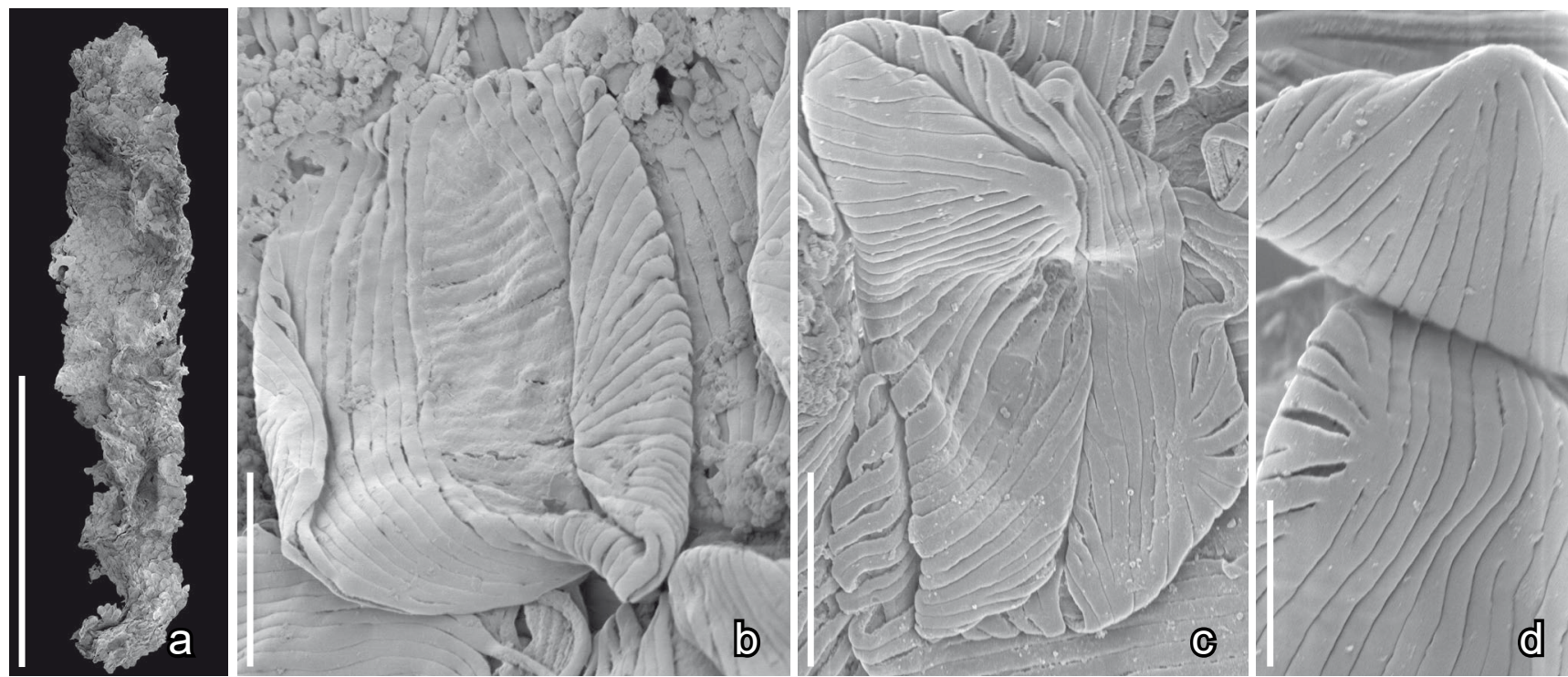

Text-fig. 34. Scanning electron microscope (SEM) images of monocolpate pollen of Mayoa portugallica from a fragmentary stamen; Torres Vedras locality, Portugal. a) Stamen fragment that yielded the pollen in this Text-figure; b-d) Pollen grains showing the distinctive perpendicular orientation of two broad bands of striae that converge at the ends of the grains. Specimen, TV44-S136663. Scale bars $150 \mu \mathrm{m}(\mathrm{a}), 6 \mu \mathrm{m}(\mathrm{b}, \mathrm{c}), 3 \mu \mathrm{m}(\mathrm{d})$.

taxa in the absence of columellae and the presence of a fine granular infratectal layer. In the pollen of all unequivocal Chloranthaceae there is no granular infratectal layer and the tectum is supported by well-developed columellae. In addition, in the pollen grains of all Chloranthaceae that have a supratectal ornamentation, the sculptural elements are densely arranged and composed of minute, rounded elements, whereas in Pennipollis the sculpturing elements are spiny with acute tips and typically much less densely distributed. Sculpturing elements of this kind are not reported for Chloranthaceae, but closely similar supratectal ornamentation is known for pollen of some extant Alismatales and other monocotyledons, a group that has been poorly represented in the phylogenetic analyses performed to date. For example, pollen of Aponogeton L.f. is monocolpate and sometimes with very short columellae (Grímsson et al. 2014). Similarly, acolumellate pollen is characteristic of several other taxa among Alismatales (Grayum 1992). All fossil fruits and stamens associated with Pennipollis are compressed and preserve few distinctive features. More informative material will be needed for a secure assessment of the phylogenetic position of the Pennistemon plant among monocotyledons and other early diverging angiosperm groups.

\section{Non-eudicot angiosperms of uncertain affinity}

R e $\mathrm{m}$ a r k s . Under this heading we describe several new angiosperm taxa with monocolpate, semitectate-reticulate and columellate pollen. Based on aperture configuration the new taxa are clearly of non-eudicot affinity, but critical features for assigning the fossils to basal grades of extant angiosperms, eumagnoliids or monocots are currently not available.

\section{Genus Eckhartianthus E.M.Fris, P.R.Crane et K.R.PEDERSEn gen. nov.}

Type. Designated here. Eckhartianthus lusitanicus E.M.Fris, P.R.Crane et K.R.Pedersen gen. et sp. nov.
Plant Fossil Names Registry Number. PFN000469 (for new genus).

Etymology. In honor of the German palynologist Eckhart Schrank in recognition of his important contribution to Cretaceous palynology and Greek: anthos for flower.

Diagnosis. Flower bisexual, trimerous with three long tepals in a single whorl, nine stamens and three carpels. Anthers dithecate and tetrasporangiate, elongate, filament broad. Pollen monocolpate, colpus long, extending almost to the equator. Exine semitectate-reticulate, with a heterobrochate reticulum, rounded muri and short, densely spaced columellae. Colpus margin well-defined psilate. Orbicules irregular, rounded. Ovary superior.

Comments on the genus. Eckhartianthus is based on a single flower, which although not fully preserved and with internal features unknown, is clearly distinct from other flowers in the Torres Vedras mesofossil flora and the flowers described so far from other Early Cretaceous mesofossil assemblages. The key distinguishing features are the superior ovary and the trimerous perianth and androecium. There is apparently a single stigma indicating that the gynoecium is syncarpous, but the preservation of internal features is poor and details of floral organization are unknown. Trimerous flowers are rare in Early Cretaceous floras and currently there are no other fossils that have a similar structure.

Pollen grains in situ within the Eckhartianthus flower are similar in general morphology to pollen grains of Eckhartia (described below), but the Eckhartianthus grains are smaller, and the orbicules are irregular, non-dentate.

\section{Eckhartianthus lusitanicus E.M.FrIIS, P.R.CRANE et K.R.Pedersen sp. nov. Text-fig. 36a-e}

H o l o t y p e. Designated here. S101306 (Torres Vedras sample 39; figured Text-fig. 36a-e). 

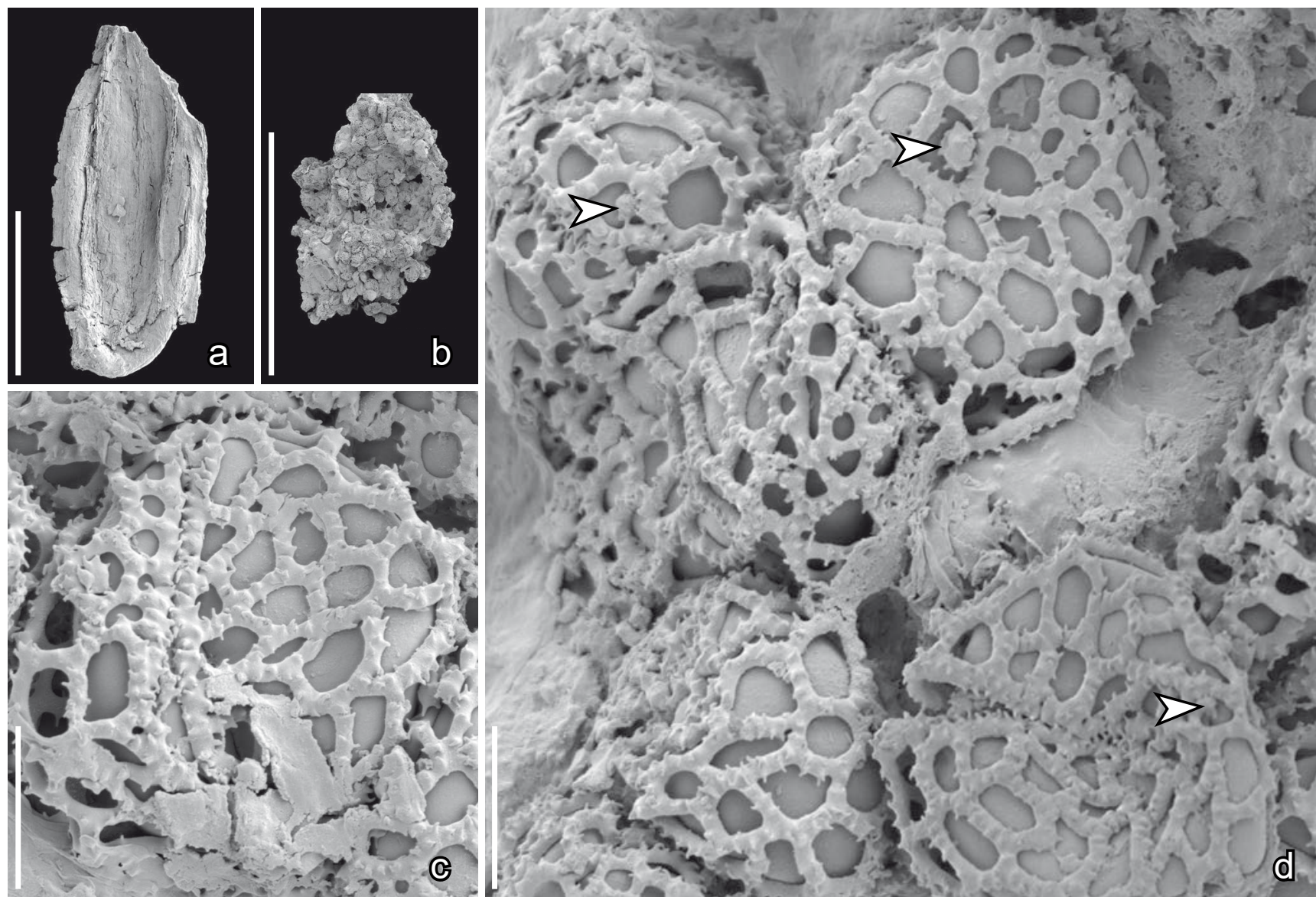

Text-fig. 35. Scanning electron microscope (SEM) images of a fruit of Pennicarpus sp. and monocolpate pollen of Pennipollis sp. from a pollen clump; Torres Vedras locality, Portugal. a) Fruit of Pennicarpus sp. showing the poorly preserved fruit wall enclosing a single seed; b) Pollen clump that yielded the pollen in this Text-figure (c, d); c, d) Pollen grains showing the loose reticulum bearing small spinules that are often in two rows; note the smooth surface of the foot layer, the absence of columellae, the continuous muri bordering the apertures and spiny orbicules (arrowheads). Specimens, TV38-S174609 (a), TV44-S148015 (b-d). Scale bars $300 \mu \mathrm{m}$ (a, b), $6 \mu \mathrm{m}$ (c, d).

Plant Fossil Names Registry Number. PFN000470 (for new species).

R e p o s i t o ry. Palaeobotanical Collections, Department of Palaeobiology, the Swedish Museum of Natural History, Stockholm, Sweden.

Etymology. From Latin: Lusitania for Portugal where the fossil was discovered.

Type locality. Torres Vedras (NE of Forte de

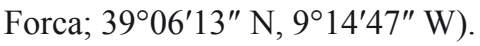

Type stratum and age. Lower member of the Almargem Formation; Early Cretaceous (late Barremianearly Aptian).

Diagnos is. As for the genus.

D i m e n s i o n s. Length of: $1 \mathrm{~mm}$; width of: $0.55 \mathrm{~mm}$. Diameter of pollen grains: 12-13 $\mu \mathrm{m}$.

Description and remarks. Eckhartianthus lusitanicus is based on a single flower with perianth, stamens and carpels partly preserved. The base of the flower is missing and there is no information on how the flower was borne on the plant. The flower is bisexual and trimerous with three long tepals apparently in a single whorl, nine stamens and three carpels (Text-fig. 36a). The ovary is superior and the stigma apparently sessile. Details of the arrangement of floral organ are uncertain.

The stamens have long broad filaments and dithecate and tetrasporangiate anthers. The anthers are elongate, apparently with longitudinal dehiscent slits. Anthers are indehisced, and full of pollen. Small, irregular rounded orbicules line the inner wall of the anthers. Pollen grains are monocolpate, semitectate-reticulate, with heterobrochate reticulum, rounded muri and short, densely spaced columellae (Textfig. 36b-e). The colpus is long extending almost to the equator and the colpus margin is distinct and psilate (Textfig. 36c). The flower was described and figured in earlier publications (Friis et al. 1994b, 2006, 2010a, 2011), but not formally named until now.

Affinity and other occurrences.Eckhartianthus lusitanicus is only known from the Torres Vedras locality. The trimerous organization may suggest affinity with monocotyledons (Friis et al. 2011), but critical features needed for a definitive systematic placement are currently lacking.

\section{Genus Eckhartia E.M.FriIs, P.R.Crane et K.R.Pedersen gen. nov.}

Type. Designated here. Eckhartia brevicolumella E.M.FriIs, P.R.Crane et K.R.Pedersen gen. et sp. nov. 

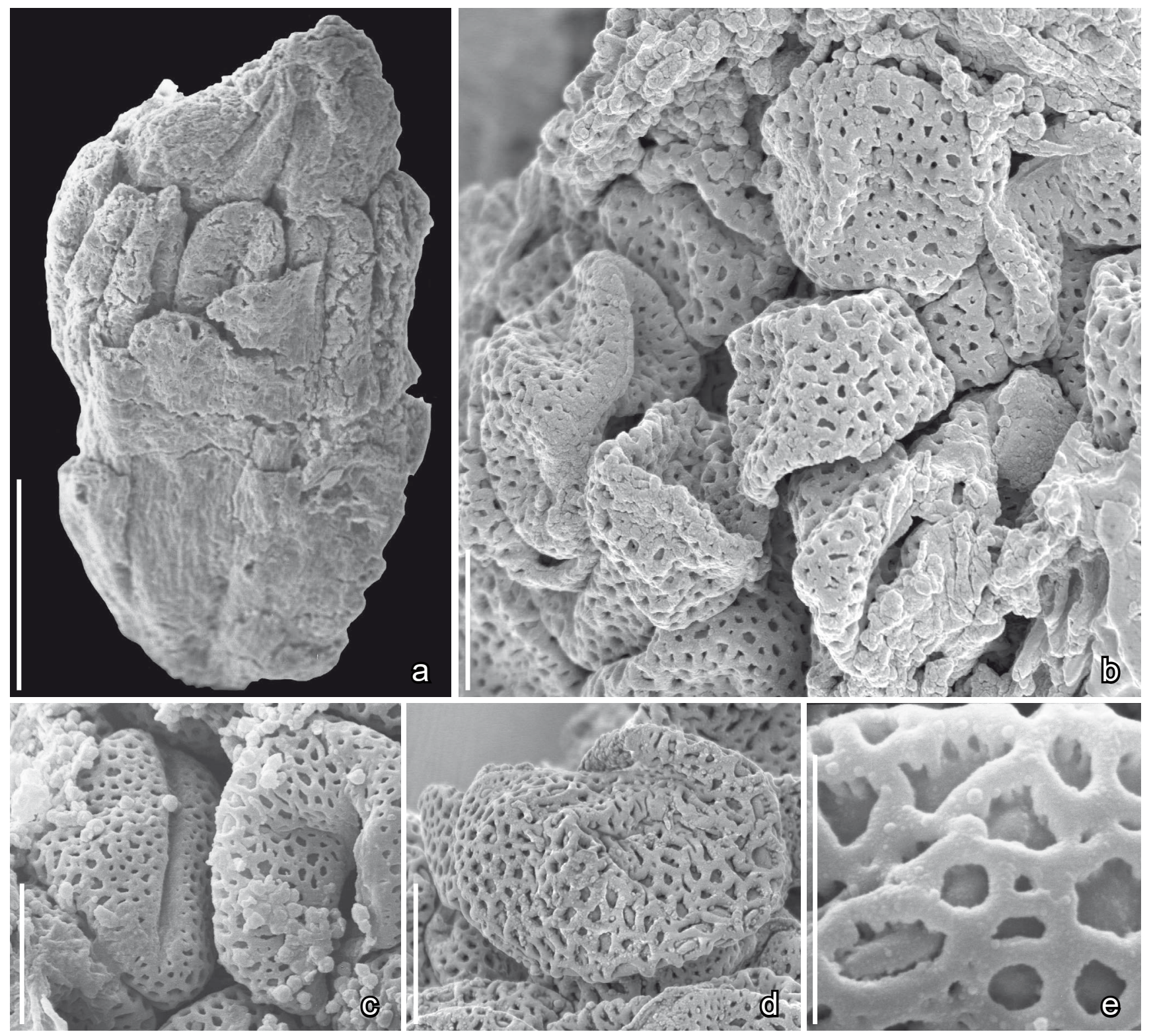

Text-fig. 36. Scanning electron microscope (SEM) images of flower of Eckhartianthus lusitanicus gen. et sp. nov.; Torres Vedras locality, Portugal. a) Holotype; oblique lateral view of hypogynous flower showing perianth surrounding the stamens and protruding gynoecium; b-d) Pollen from the flower in (a) showing single distal aperture and reticulate exine with thick muri, small lumina and short, densely spaced columellae; e) Reticulum showing thick, smooth muri supported by numerous short columellae firmly attached to the smooth surface of the foot layer. Specimen, TV39-S101306 (holotype). Scale bars $300 \mu \mathrm{m}$ (a), $6 \mu \mathrm{m}$ (b-d), $3 \mu \mathrm{m}(\mathbf{e})$.

Plant Fossil Names Registry Number. PFN000471 (for new genus).

Etymology. In honor of the German palynologist Eckhart Schrank in recognition of his important contribution to Cretaceous palynology.

Diagnosis. Stamens with long anthers. Anther tetrasporangiate and dithecate. Pollen small, almost circular in equatorial outline, monocolpate. Colpus extending for the full length of the pollen grains. Exine semitectate-reticulate and columellate. Reticulum heterobrochate; identical on the proximal and distal faces; lumina isodiametric and polygonal to rounded. Muri smooth with flattened to slightly rounded profiles, supported by long distinct columellae. Colpus membrane granular. Colpus margin distinct with psilate regions around the end of the colpus. Orbicules large, dentate and densely distributed on inner surface of the anther wall.

Comments on the genus. Dispersed monocolpate pollen grains with semitectate-reticulate and columellate pollen wall are typically assigned to the extinct pollen genus Retimonocolpites R.L.PIERCE, described from the Late Cretaceous of Minnesota, USA (Pierce 1961). However, very few of the dispersed pollen grains assigned to the genus conform with the features of the type species, Retimonocolpites dividuus R.J.PIERCE, which is characterized by having "an aperture that almost encircles grain dividing it into two hemispheres; one polar and one equatorial plane of symmetry" (Pierce 1961). The many species assigned to Retimonocolpites in the past undoubtedly belong to taxa of 
widely different systematic affinities. In the Torres Vedras mesofossil flora, as well as in many other Early Cretaceous mesofossil floras, pollen of this general kind have been found in different kinds of anthers or consistently on the stigmatic surfaces of flowers and fruits that are systematically distinct. In order not to obscure the systematic diversity of Early Cretaceous angiosperms we therefore establish several new genera for some of the pollen types that would otherwise be lumped together into a highly heterogeneous Retimonocolpites.

\section{Eckhartia brevicolumella E.M.FRIIS, P.R.CRANE et K.R.Pedersen sp. nov. Text-fig. $37 \mathrm{a}-\mathrm{g}$}

H o l o t y p e. Designated here. S136760 (Torres Vedras sample 44; figured Text-fig. 37c, g).

Plant Fossil Names Registry Number. PFN000472 (for new species).

P a ratypes. Designated here. S136661, S136662, S136751, S136752, S136673, S136765, S137920, S137921, S148021, S149204 (Torres Vedras sample 44).

Re p o s i t ory. Palaeobotanical Collections, Department of Palaeobiology, the Swedish Museum of Natural History, Stockholm, Sweden.

Etymology. From Latin: brevis for short and columella referring to short columellae supporting the muri.

Type locality. Torres Vedras (NE of Forte de Forca; 39 $06^{\prime} 13^{\prime \prime} \mathrm{N}, 9^{\circ} 14^{\prime} 47^{\prime \prime} \mathrm{W}$ ).

Type stratum and age. Lower member of the Almargem Formation; Early Cretaceous (late Barremianearly Aptian).

Diagnosis. As for the genus with the following additions: Anthers elongate. Reticulum coarse. Columellae short, densely spaced or sometimes laterally merged.

Distinguishing features. Eckhartia brevicolumella is distinct from E. longicolumella (below) mainly in having much longer stamens, pollen grains with larger and fewer lumina and shorter, more densely spaced columellae. The coarse reticulum of the pollen grains also distinguishes Eckhartia brevicolumella from E. intermedia (below) although these two taxa both have similar short and densely spaced columellae.

Dimensions. Length of anthers: about $1.2 \mathrm{~mm}$; width of anthers: $0.12-0.16 \mathrm{~mm}$. Length of pollen grains: 16-17 $\mu \mathrm{m}$.

Description and remarks. Eckhartia brevicolumella is based on many isolated stamens with pollen grains in situ. It was first illustrated by Friis et al. (2010a), but not formally described and named. The anthers are very long and narrow, about $1.2 \mathrm{~mm}$ long and $0.12-0.16 \mathrm{~mm}$ wide, dithecate and tetrasporangiate (Text-fig. 37a, b). The anther wall is usually well preserved and pollen grains are only visible in cracks or fragmented specimens. Pollen grains are about $16-17 \mu \mathrm{m}$ in equatorial diameter and monocolpate. The exine is semitectate-reticulate, heterobrochate and columellate (Text-fig. 37c, d, f, g). The reticulum over most of the pollen grain is coarse with lumina of two sizes, with the larger lumina up to about $1.8 \mu \mathrm{m}$ in diameter (Textfig. $37 \mathrm{~g}$ ). Towards the colpus margin, and especially around the end of the colpus, the lumina become very small and the colpus margin is psilate (Text-fig. 37f, g). Muri are about $0.2 \mu \mathrm{m}$ wide with rounded or flattened profiles. Columellae are short, about $0.2 \mu \mathrm{m}$ long, usually densely spaced, and sometimes fused into a short plates (Text-fig. $37 \mathrm{~g}$ ). Orbicules are densely spaced on the inner surface of the anther wall (Text-fig. 37e) and scattered over the surface of the pollen grains (Text-fig. $37 \mathrm{~g}$ ). They are about $1.8 \mu \mathrm{m}$ long, irregular in shape with a solid rounded base bearing densely spaced rod-like protrusions that give the individual orbicules the appearance of a tooth with crown and roots (Textfig. 37e, g).

Affinity and other occurrences. The pollen grains show similarities to grains adhering to the stigmatic surface of Vedresia elliptica (Text-fig. 49c) and they may have been produced by the same kind of plant. Eckhartia brevicolumella has so far not been observed in any other mesofossil flora from Portugal.

\section{Eckhartia longicolumella E.M.FriIS, P.R.CRANE et K.R.Pedersen sp. nov. Text-fig. $38 \mathrm{a}-\mathrm{i}$}

H o l o t y p e. Designated here. S136754 (Torres Vedras sample 44; figured Text-fig. 38b-i).

Plant Fossil Names Registry Number. PFN000473 (for new species).

P a r atypes. Designated here. S136673, S137901 (Torre Vedras sample 44).

R e p o s i t o ry. Palaeobotanical Collections, Department of Palaeobiology, the Swedish Museum of Natural History, Stockholm, Sweden.

E t y m o l o g y. From Latin: longus for long and columella referring to the long columellae supporting the muri.

Type locality. Torres Vedras (NE of Forte de

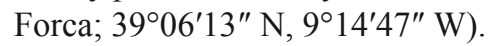

Type stratum and age. Lower member of the Almargem Formation; Early Cretaceous (late Barremianearly Aptian).

Diagnosis. As for the genus with the following additions: Anthers long and narrow. Reticulum fine. Columellae long, scattered.

Distinguishing features. See comments for Eckhartia brevicolumella and E. intermedia.

D imensions. Length of anthers: about $0.55 \mathrm{~mm}$; width of anthers: $0.15 \mathrm{~mm}$. Length of pollen grains: $16-19 \mu \mathrm{m}$.

Description and remarks. Eckhartia longicolumella is based on a single well-preserved anther and several anther fragments. It was first illustrated by Friis et al. (2010a), but not formally described or named. The anthers are about $0.55 \mathrm{~mm}$ long, $0.15 \mathrm{~mm}$ wide and are dithecate and tetrasporangiate (Text-fig. 38a, b). 

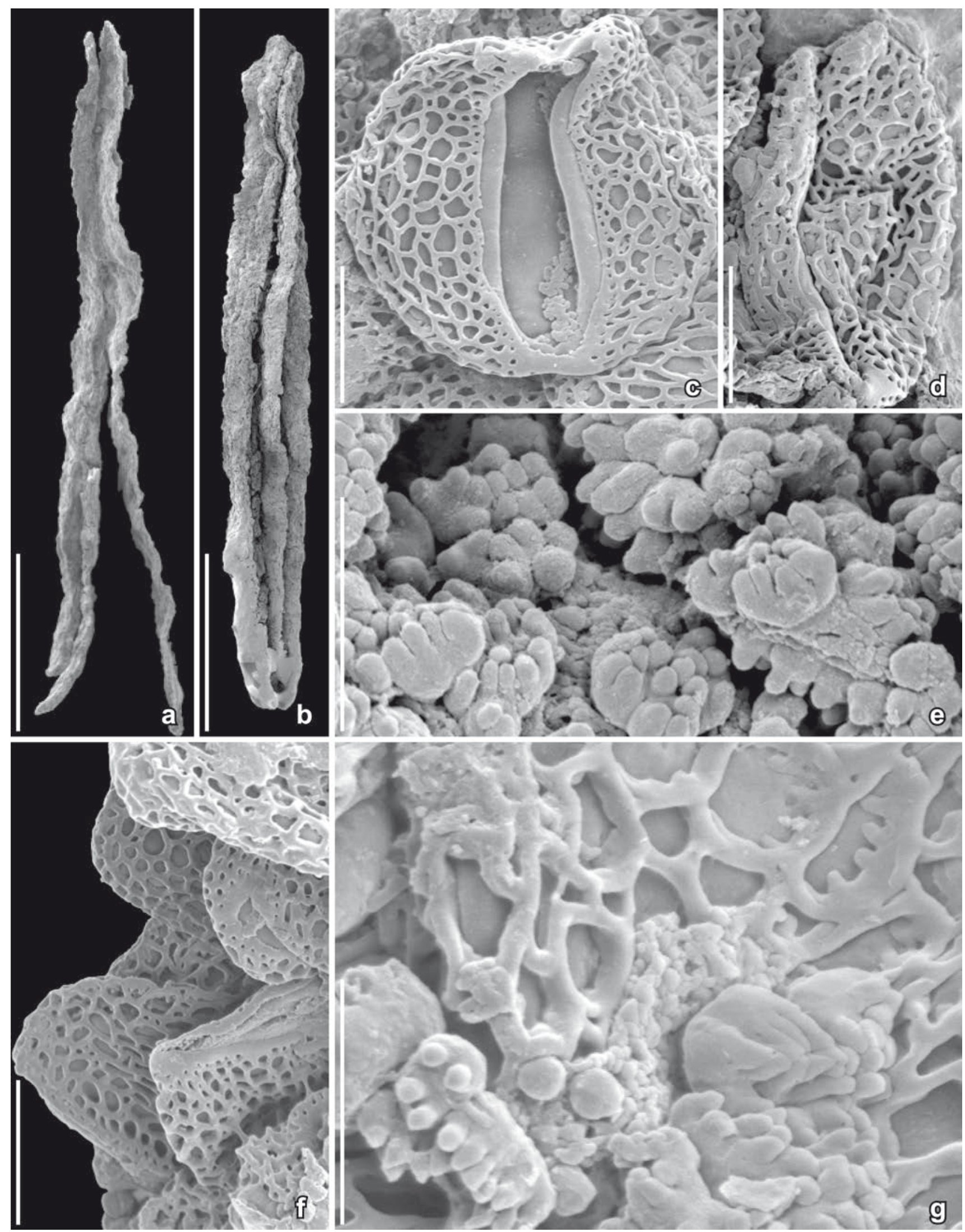

Text-fig. 37. Scanning electron microscope (SEM) images of anthers and monocolpate pollen of Eckhartia brevicolumella gen. et sp. nov. from stamen fragment; Torres Vedras locality, Portugal. a) Dithecate, tetrasporangiate anther partially split along the elongated sporangia; b) Dithecate, tetrasporangiate anther; c) Holotype; distal view of pollen grain from holotype showing the long colpus with a distinct margin and a heterobrochate reticulum; d) Distal view of pollen grain from a stamen fragment showing long colpus, colpus margin and heterobrochate reticulum; e) Inner surface of anther wall from stamen fragment showing densely spaced dentate orbicules; f) Lateral view of pollen grains from stamen showing the psilate to foveolate-microreticulate colpus margin; g) Detail of pollen grain from holotype showing the slightly rounded profile of the muri, the short, densely spaced columellae and the dentate orbicules. Specimens, TV44-S136662 (a), TV44-S149204 (b), TV44-S136760 (holotype; c, g), TV44-S148021 (d, e), TV44-S136752 (f). Scale bars $300 \mu \mathrm{m}$ (a, b), $6 \mu \mathrm{m}$ (c, d, f), $3 \mu \mathrm{m}(\mathrm{e}, \mathrm{g})$. 

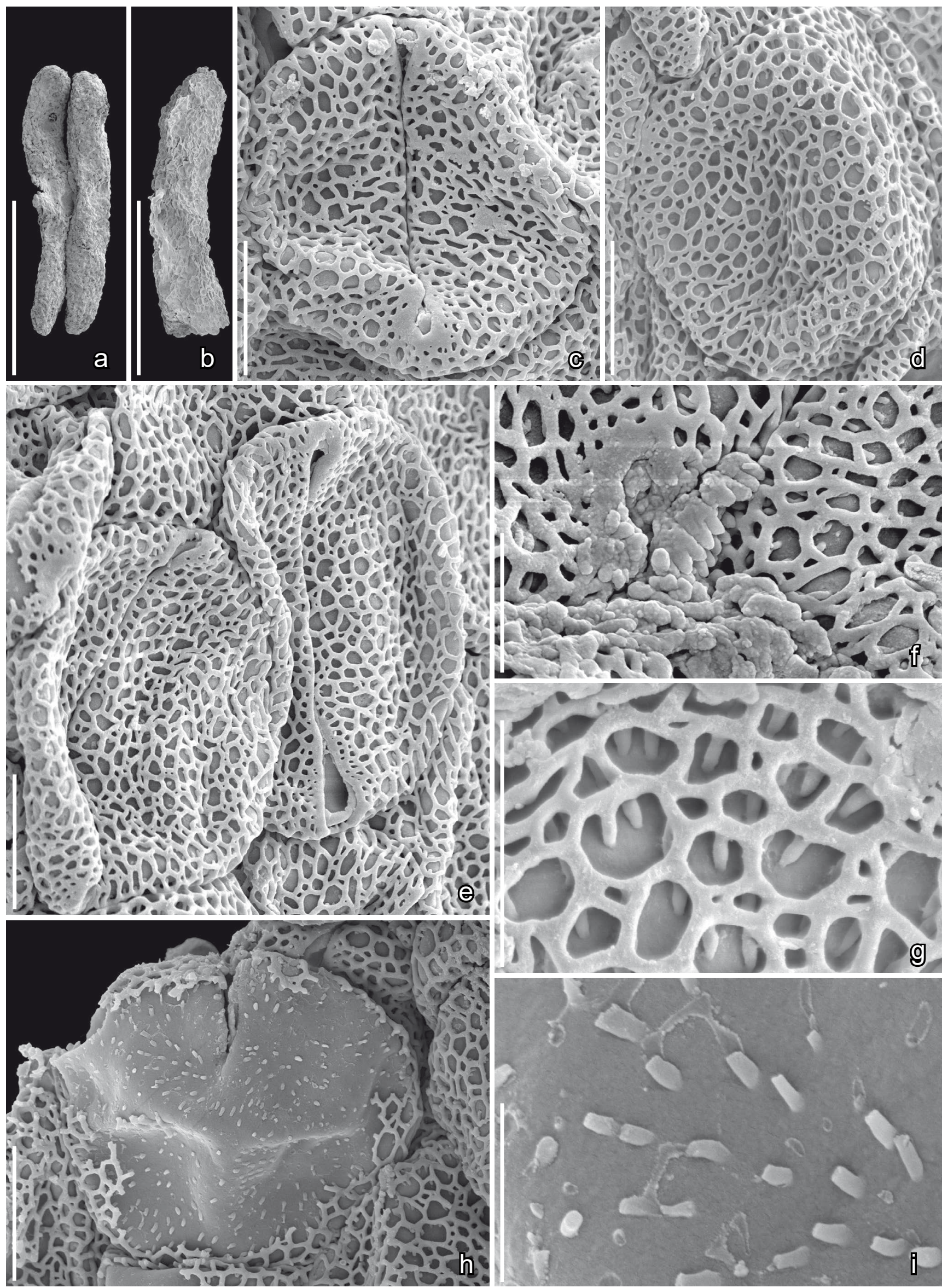

Text-fig. 38. Scanning electron microscope (SEM) images of anthers and monocolpate pollen of Eckhartia longicolumella sp. nov. from stamen fragment; Torres Vedras locality, Portugal. a) Dithecate, tetrasporangiate anther that yielded the same kind of pollen as the holotype (b); b) Holotype; stamen fragment that yielded the pollen shown in this Text-figure; c-e) Pollen grains showing the elongated colpi, reticulum with large and small luminae and continuous muri along the aperture margins; $f$, g) Pollen grains in 
Pollen grains are about $16-19 \mu \mathrm{m}$ in equatorial diameter and monocolpate. The exine is semitectate-reticulate, heterobrochate and columellate (Text-fig. 38c-i). The reticulum over most of the pollen grain is relatively fine compared to the reticulum of Eckhartia brevicolumella. Lumina are of two sizes; larger lumina are up to about $1.35 \mu \mathrm{m}$ in diameter (Text-fig. 38g). Towards the colpus margin, and particularly around the end of the colpi, the lumina become very small and the colpus margin is psilate (Text-fig. 38c, e, f). Muri are about $0.2 \mu \mathrm{m}$ wide with a rounded or flattened profile. Columellae are long, about $0.45 \mu \mathrm{m}$ long, typically widely spaced (Text-fig. $38 \mathrm{~g}, \mathrm{i}$ ). The reticulum is only loosely attached and easily separates from the foot layer, leaving the foot layer naked or with only columellae attached (Text-fig. 38 h, i). Orbicules are densely distributed on the inner surface of the anther wall and scattered among the pollen grains (Text-fig. 38f). The orbicules are closely similar to the tooth-like orbicules of $E$. brevicolumella (Text-fig. 38f).

Affinity and other occurrences. Like Eckhartia brevicolumella, E. longicolumella has not been observed in any other mesofossil flora from Portugal. The grains of E. longicolumella resemble the grains found on the stigmatic surface of Canrightia sp. described here (p. 183 herein), but differ in the shape of the muri and details of the reticulum.

\section{Eckhartia intermedia E.M.FrIIS, P.R.CRANE et K.R.Pedersen sp. nov. Text-fig. 39a-e}

H o l o t y p e. Designated here. S148209 (Torres Vedras sample 43; figured Text-fig. 39a-e).

Plant Fossil Names Registry Number. PFN000474 (for new species).

R e p o s i t o ry. Palaeobotanical Collections, Department of Palaeobiology, the Swedish Museum of Natural History, Stockholm, Sweden.

Etymology. From Latin: intermedium referring to the intermediate nature of the tectum between the two other species of Eckhartia: similar to Eckhartia longicolumella in the fine reticulum and similar to E. brevicolumella in the short columellae.

Type locality. Torres Vedras (NE of Forte de Forca; $\left.39^{\circ} 06^{\prime} 13^{\prime \prime} \mathrm{N}, 9^{\circ} 14^{\prime} 47^{\prime \prime} \mathrm{W}\right)$.

Type stratum and age. Lower member of the Almargem Formation; Early Cretaceous (late Barremianearly Aptian).

Diagnosis. As for the genus with the following additions: Reticulum fine. Columellae short and densely arranged.
Distinguishing features. Anthers are not known for this species. Pollen grains are similar to Eckhartia longicolumella in their fine reticulum, and similar to $E$. brevicolumella in their short, densely spaced columellae.

$\mathrm{D}$ i m e n s i o n s . Length of pollen grains: about $16 \mu \mathrm{m}$.

Description and remarks. Eckhartia intermedia is based on the pollen grains observed in a pollen clump that contains only a single kind of pollen, and is probably a fragment of a stamen (Text-fig. 39a).

Pollen grains are about $16 \mu \mathrm{m}$ in equatorial diameter, monocolpate, semitectate-reticulate, heterobrochate and columellate (Text-fig. 39b-e). The reticulum over most of the grains is relatively fine compared to the reticulum of Eckhartia brevicolumella. Smaller lumina are scattered among the larger lumina, with the larger lumina up to about $0.9 \mu \mathrm{m}$ in diameter (Text-fig. 39e). The colpus margin is not well exposed in any of the grains, but it is clear that lumina are smaller and the tectum is psilate at the ends of the colpus (Text-fig. 39d). Muri are about $0.2 \mu \mathrm{m}$ wide with rounded profile. Columellae are short, about $0.2 \mu \mathrm{m}$ long, and densely spaced (Text-fig. 39e). Tooth-shaped and rounded orbicules have been observed on the surfaces between the pollen grains, but they are rare, perhaps because the pollen are found in a pollen clump without remains of the anther wall.

Affinity and other occurrences.Eckhartia intermedia is known only from the Torres Vedras mesofossil flora.

\section{Eckhartia sp.}

(Text-fig. 39f-k)

Description and remarks. Several narrow anther fragments, up to about $0.5 \mathrm{~mm}$ long and $0.1 \mathrm{~mm}$ wide (Text-fig. 39f, g), with in situ monocolpate pollen are referred to the new genus Eckhartia based on the shape of the anthers and the morphology of the in situ pollen. Pollen grains are monocolpate. The exine is semitectate-reticulate, heterobrochate and columellate. The colpus margin is distinctive, psilate to microreticulate (Text-fig. 39i).

The pollen grains of Eckhartia sp. are about $8 \mu \mathrm{m}$ in equatorial diameter, much smaller than those of Eckhartia brevicolumella, E. intermedia and E. longicolumella. Lumina are of two sizes as in the other three species, but the smaller lumina are distinctive in often being arranged in rows (Text-fig. 39j, k). Like E. brevicolumella and E. longicolumella, Eckhartia sp. also has scattered, relatively large dentate orbicules (Text-fig. 39h, k), but most of the orbicules are small, irregular and rounded bodies that are densely scattered on the inner surface of the anther wall (Text-fig. 39h).

Pollen grains of Eckhartia sp. from the anther in Textfig. $39 \mathrm{~g}$ were figured by us as Pollen type D.7 (Friis et al.

distal (c, e) and proximal (d) views showing the reticulum with smooth muri supported by long columellae that are firmly attached to the smooth surface of the foot layer; note that the muri delimit luminae of two markedly different sizes; $h$, i) Pollen grains in which the reticulum has become detached exposing the smooth surface of the foot layer with attached long columellae. Specimens, TV44-S137901 (a), TV44-S135754 (holotype; b-i). Scale bars $300 \mu \mathrm{m}$ (a, b), $6 \mu \mathrm{m}$ (c, d, e, h), $3 \mu \mathrm{m}$ (f, g), $1.5 \mu \mathrm{m}$ (i). 

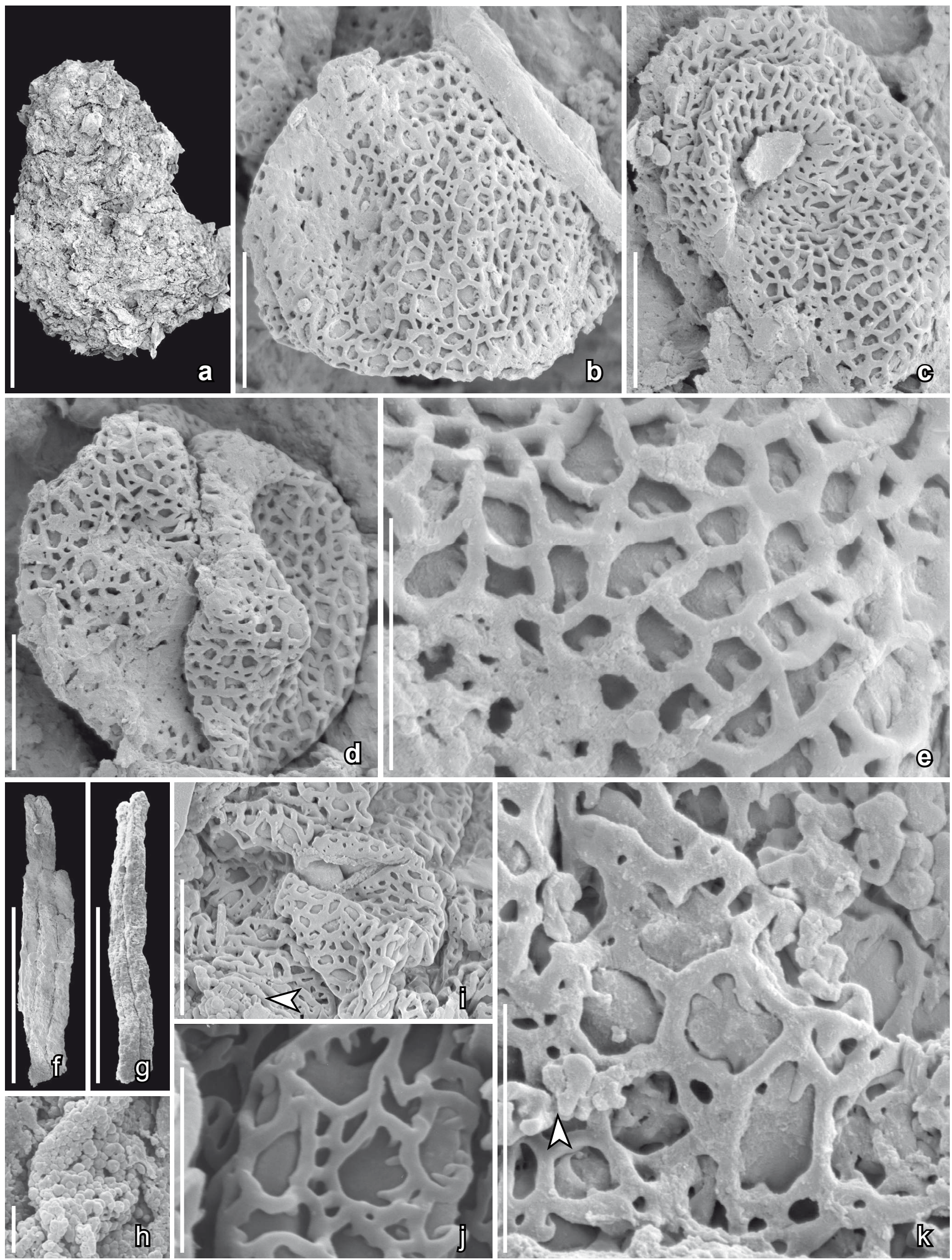

Text-fig. 39. Scanning electron microscope (SEM) images of monocolpate pollen of Eckhartia intermedia sp. nov. from a pollen clump, probably fragment of a stamen (a-e) and anthers and pollen of Eckhartia sp. (f-k); Torres Vedras locality, Portugal. a) Pollen clump that yielded the pollen in (b-e); b-d) Pollen grains viewed from distal (d) and proximal surfaces (b, c) showing the long colpus and well-developed reticulum with large and small luminae; e) Reticulum showing smooth muri supported by short columellae firmly attached to the smooth surface of the foot layer; note the occasional small luminae; f, g) Fragments of narrow elongate anthers with same kind of pollen as in (i); h) Inner surface of anther wall showing small spherical orbicules; 
1999). The grains are only partly exposed in the anther fragments and there are no grains with well-exposed distal face. We therefore decline to create a new species. It is also possible that more than one species is present among the anther fragments and pollen assigned here to Eckhartia sp.

Affinity and other occurrences.Eckhartia sp. is known only from the Torres Vedras mesofossil flora.

\section{Genus Eckhartiopsis E.M.FriIS, P.R.Crane et K.R.Pedersen gen. nov.}

Ty p e. Designated here. Eckhartiopsis parva E.M.FrIIS, P.R.Crane et K.R.Pedersen gen. et sp. nov.

Plant Fossil Names Registry Number. PFN000475 (for new genus).

Etymology. From the generic name Eckhartia and Greek: -opsis (appearance) to indicate close similarity between the two taxa.

D i a g n o s i s. Stamens with long tetrasporangiate and dithecate anthers. Pollen grains small, almost circular in equatorial outline, monocolpate, colpus extending for the full length of the grains. Exine semitectate-reticulate and columellate. Reticulum heterobrochate; heteropolar with coarser reticulum on proximal face than on distal face. Muri smooth with flattened to slightly rounded profiles, supported by long distinct columellae. Colpus margin distinct, microreticulate, lacking psilate regions around the end of the colpus. Colpus membrane granular. Orbicules large, dentate, densely scattered on inner surface of the anther wall.

Comments on the genus. The anthers and in situ pollen grains of Eckhartiopsis are closely similar to those of Eckhartia, and all have tooth-like orbicules. However, the anther is broader with more protruding sporangia and the pollen grains differ in their heteropolar reticulum and the absence of psilate regions at the ends of the colpi.

\section{Eckhartiopsis parva E.M.FriIs, P.R.Crane et K.R.PEDERSEN sp. nov. Text-fig. 40a-h}

H o l o t y p e . Designated here. S170217 (Torres Vedras sample 39; figured Text-fig. 40a-h).

Plant Fossil Names Registry Number. PFN000476 (for new species).

Re pos i t ory. Palaeobotanical Collections, Department of Palaeobiology, the Swedish Museum of Natural History, Stockholm, Sweden.

E t y m o log y. From Latin: parvus for small referring to small size of the pollen grains.

Type locality. Torres Vedras (NE of Forte de Forca; 3906'13" N, 9¹4'47" W).
Type stratum and age. Lower member of the Almargem Formation; Early Cretaceous (late Barremianearly Aptian).

D i a g no sis. As for the genus.

Distinguishing features. Eckhartiopsis parva is distinguished from Eckhartia as represented in the Torres Vedras mesofossil flora (Eckhartia brevicolumella, Eckhartia longicolumella, Eckhartia sp.) by the broader anthers and the heteropolarity of the reticulum, in which the reticulum on the proximal surface is coarser than the reticulum on distal surface. Pollen grains of Eckhartiopsis also lack the distinct psilate region at the ends of the colpi that is characteristic of Eckhartia pollen. Nevertheless, Eckhartia and Eckhartiopsis have similar tooth-shaped orbicules and it is possible that they are systematically closely related.

D imensions. Length of anthers: about $0.53 \mathrm{~mm}$; width of anthers: $0.25 \mathrm{~mm}$. Length of pollen grains: 14 $15 \mu \mathrm{m}$.

Description and remarks. The species is based on a single well-preserved anther. The anther is dithecate and tetrasporangiate, about $0.53 \mathrm{~mm}$ long and $0.25 \mathrm{~mm}$ wide (Text-fig. 40a).

Pollen grains are about $14-15 \mu \mathrm{m}$ in equatorial diameter and monocolpate. The exine is semitectate-reticulate, heterobrochate and columellate (Text-fig. 40b-g). The reticulum is coarser on the proximal face than on the distal face (Text-fig. 40c-e). Larger lumina on the proximal face are up to about $1.5 \mu \mathrm{m}$ in diameter (Text-fig. 40c). Lumina on the distal face are smaller, and only slightly smaller along the colpus margin (Text-fig. 40e, f). Muri are about $0.2 \mu \mathrm{m}$ wide with a rounded or flattened profile. Columellae are long, about $0.5 \mu \mathrm{m}$ tall and typically widely spaced (Textfig. $40 \mathrm{c}, \mathrm{h}$ ). The foot layer is about $0.4 \mu \mathrm{m}$ thick (Text-fig. $40 \mathrm{~h})$. The endexine is granular, apparently very restricted, and developed only under the aperture (Text-fig. 40h). The reticulum loosens easily from the foot layer sometimes leaving the main body of the grain naked (Text-fig. 40g). Orbicules are densely scattered on the inner surface of the anther wall and over the surface of the pollen grains (Textfig. 40b, e). They are tooth-like with pointed protrusions.

Affinity and other occurrences. Eckhartiopsis parva is currently not known from any other mesofossil flora in Portugal.

\section{Genus Piercipollis E.M.Fris, P.R.Crane et K.R.PEDERSEN gen. nov.}

Ty p e. Designated here. Piercipollis simplex E.M.FrIIS, P.R.Crane et K.R.Pedersen gen. et sp. nov.

Plant Fossil Names Registry Number. PFN000477 (for new genus).

i) Monocolpate semitectate-reticulate pollen grain from anther showing distinct colpus margin with minute lumina; note dentate orbicules (arrowhead); j) Reticulum showing larger and smaller lumina and long columellae; k) Reticulum of pollen grain from anther fragment in (f) showing large and small luminae and long, scattered columellae; note spherical and dentate (arrowhead) orbicules on the pollen wall. Specimens, TV43-S148209 (holotype; a-e), TV44-S136750 (f, k), TV44-S105021 (g, h,j). TV44-S136751 (i). Scale bars $300 \mu \mathrm{m}$ (f, g), $150 \mu \mathrm{m}$ (a), $6 \mu \mathrm{m}$ (b-d, i), $3 \mu \mathrm{m}$ (e, h, j, k). 
Ety mology. In honor of the American palynologist Richard L. Pierce in recognition of his important contributions to Cretaceous palynology.

D i a g o s is . Pollen small, almost circular in equatorial outline, monocolpate. Colpus extending for the full length of the grains. Exine semitectate-reticulate and columellate. Reticulum coarse, homobrochate with isodiametric, polygonal to rounded lumina. Muri smooth with flattened to slightly rounded profiles, supported by long scattered columellae. Colpus margin distinct, delimited by a continuous border formed by the marginal muri of the
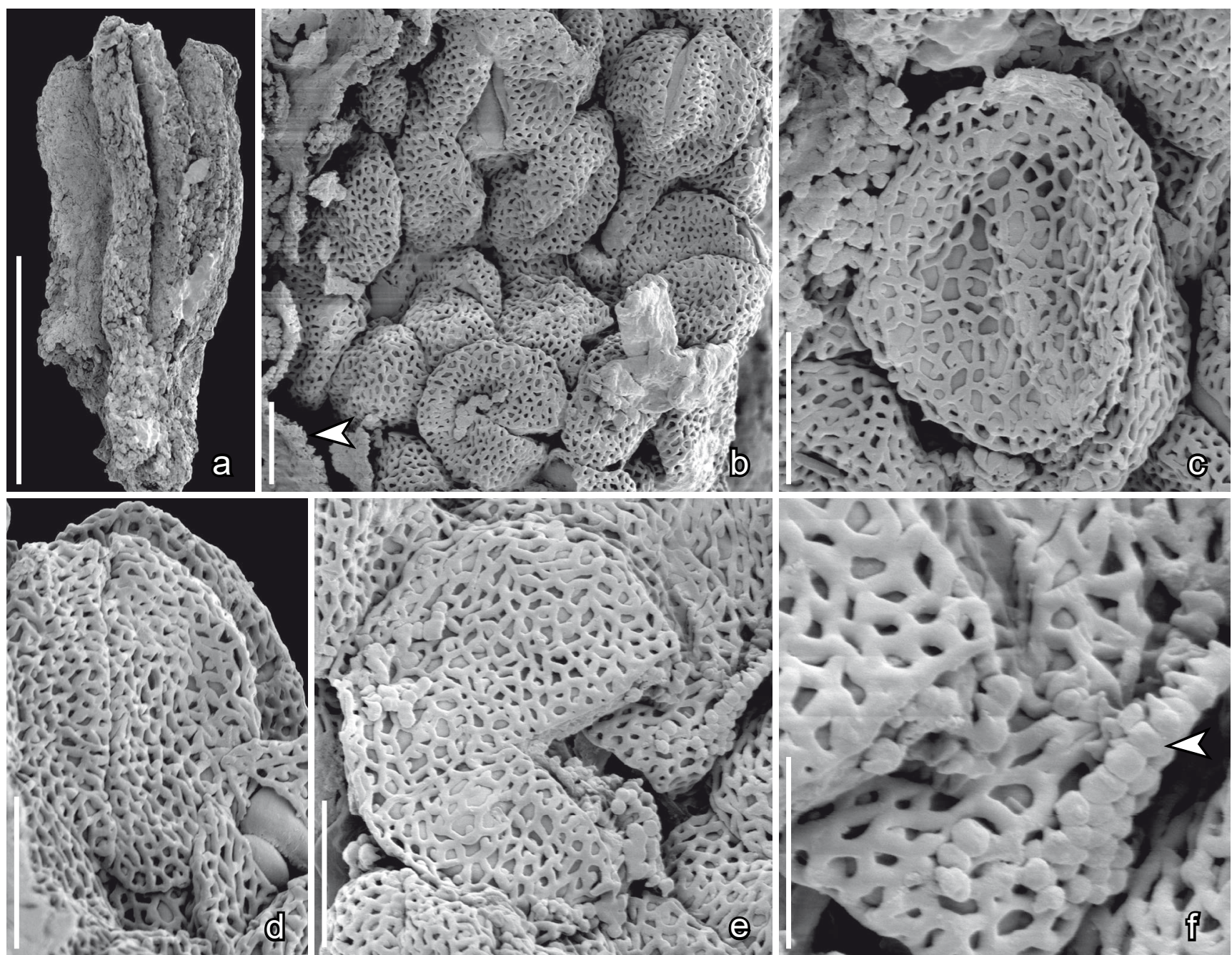

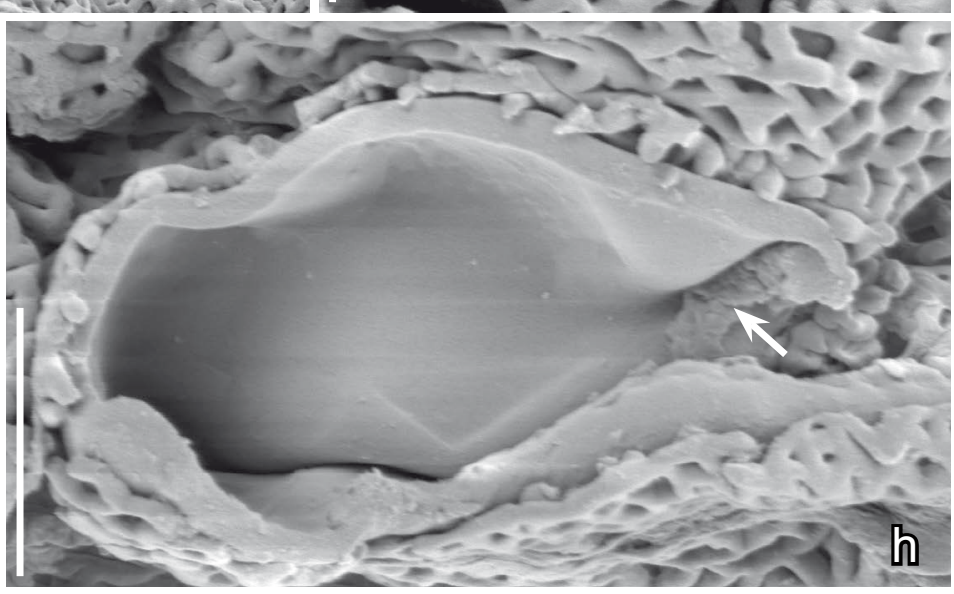

Text-fig. 40. Scanning electron microscope (SEM) images of monocolpate pollen of Eckhartiopsis parva gen. et sp. nov. from an anther; Torres Vedras locality, Portugal. a) Holotype; elongated anther that yielded the pollen in this Text-figure; b-e) Pollen grains showing dense reticulate tectum supported by short columellae that are only loosely attached to the smooth surface of the foot layer: note dentate orbicules on inner surface of anther wall (b, arrowhead); $f$ ) Reticulate tectum showing smooth muri with small adhering orbicules (arrowhead); g) Pollen grains showing one in which the reticulum has been lost exposing the smooth surface of the foot layer; $h$ ) Fractured pollen wall showing reticulum, short columellae and thick foot layer; note granules on the inner surface of the apertural region (arrow). Specimen, TV39-S170217 (holotype). Scale bars $300 \mu \mathrm{m}$ (a), $6 \mu \mathrm{m}$ (b-e, g), $3 \mu \mathrm{m}$ (f, h). 
reticulum. Reticulum larger than the main body of the pollen grain to which it is only loosely attached.

Comments on the genus. The genus is distinguished from Retimoncolpites dividuus described by Pierce (1961), the type species of Retimonocolpites, in having a colpus that extends to the equator and is restricted to the distal half of the grains. In $R$. dividuus the colpus extends around the grain dividing the grain into two halves. Pollen of Piercipollis is distinguished from grains of Eckhartia and Eckhartiopsis in having a homobrochate, rather than heterobrochate reticulum, and a colpus margin that is clearly differentiated by the marginal muri of the reticulum.
Piercipollis simplex E.M.FriIS, P.R.Crane et K.R.Pedersen sp. nov.

Text-fig. 41a-e

H o l o ty p e. Designated here. S136755 (Torres Vedras sample 44; figured Text-fig. 41a-e).

Plant Fossil Names Registry Number. PFN000478 (for new species).

P a r a ty pes. S136757, S148017, S148218 (Torres Vedras sample 44).

R e p o s i t ory. Palaeobotanical Collections, Department of Palaeobiology, the Swedish Museum of Natural History, Stockholm, Sweden.
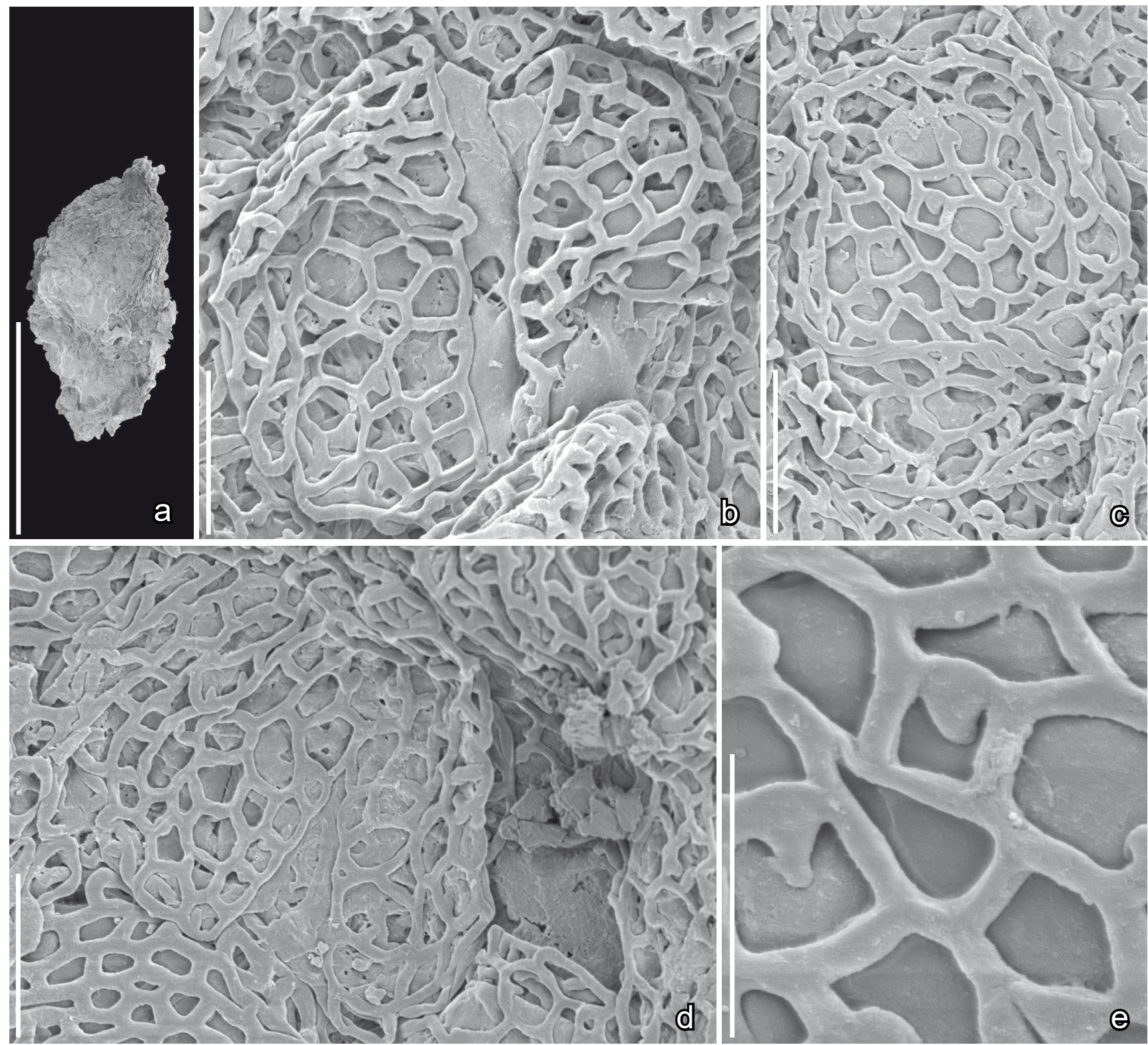

Text-fig. 41. Scanning electron microscope (SEM) images of monocolpate pollen of Piercipollis simplex gen. et sp. nov. from a pollen clump; Torres Vedras locality, Portugal. a) Holotype; pollen clump that yielded the pollen in this Text-figure; b-d) Pollen grains in distal (b), proximal (c) and lateral views (d) showing the very long colpus and the well-developed reticulum that is only loosely attached to the smooth surface of the foot layer; note the large angular lumina, smooth muri and short, sparsely scattered, columellae; note also that main body of pollen grains (foot layer) does not fill out the whole space of the reticulum; e) Reticulum showing the smooth muri loosely attached to the smooth surface of the foot layer by short, sparsely scattered, columellae. Specimen, TV44-S136755 (holotype). Scale bars $300 \mu \mathrm{m}$ (a), $6 \mu \mathrm{m}$ (b-d), $3 \mu \mathrm{m}$ (e). 
Etymology. From Latin: simplex referring to the simple reticulum and colpus margin.

Type locality. Torres Vedras (NE of Forte de Forca; 39 $06^{\prime} 13^{\prime \prime} \mathrm{N}, 9^{\circ} 14^{\prime} 47^{\prime \prime} \mathrm{W}$ ).

Type stratum and age. Lower member of the Almargem Formation; Early Cretaceous (late Barremianearly Aptian).

Di a $\mathrm{g}$ o s is. As for the genus.

D i m e n s i o n s. Length of pollen grains: about $15 \mu \mathrm{m}$.

Description and remarks. The species is based on four pollen clumps containing many pollen grains of the same kind. The pollen clumps are perhaps fragments of anthers (Text-fig. 41a). The pollen grains are small, almost circular in equatorial outline, about $15 \mu \mathrm{m}$ in diameter, and monocolpate. The colpus is long, extending to the equator. The exine is semitectate-reticulate and columellate (Textfig. $41 \mathrm{~b}-\mathrm{d})$. The reticulum is coarse, homobrochate and with polygonal to rounded lumina up to about $0.35 \mu \mathrm{m}$ wide (Text-fig. 41e). The muri are smooth with a slightly rounded profile and are supported by long scattered columellae. The colpus is distinctly delimited by a continuous line formed by the marginal muri of the reticulum. There is no difference in the form of the reticulum close to the colpus compared to over the main body of the grain (Text-fig. $41 \mathrm{~b}, \mathrm{~d}$ ). The reticulum is often detached from, and larger than, the main body of the pollen grain (Text-fig. 41b-d).

Affinity and other occurrences. A single pollen grain similar to Piercipollis simplex has also been observed in a coprolite from the Catefica locality, but otherwise the species is unknown from other mesofossil floras in Portugal.

\section{Piercipollis sp. 1}

Text-fig. $42 \mathrm{a}-\mathrm{c}$

Description and remarks. Piercipollis sp. 1 is based on an isolated anther containing abundant pollen (Text-fig. 42a). The pollen grains are small, about $20 \mu \mathrm{m}$ in diameter, and monocolpate. The colpus is long, apparently extending to the equator, but none of the grains expose the full length of colpus. The exine is semitectate-reticulate and columellate (Text-fig. 42b). The reticulum is coarse, homobrochate and with lumina up to about $0.25 \mu \mathrm{m}$ in diameter that have polygonal to rounded, irregular outlines (Text-fig. 42c). The muri are smooth with slightly rounded profiles and are supported by long scattered columellae. The colpus margin is distinctly delimited by the continuing marginal muri and there is no distinction between the reticulum over the main part of the grains and the reticulum close to the colpus margin. The reticulum detaches easily from the foot layer (Text-fig. 42b, c).

The pollen grains of Piercipollis sp. 1 differ from those of Piercipollis simplex in their more dense reticulum, and lumina of more irregular shape. However, incomplete information on the extension of the colpus, and also of details of the colpus margin, preclude formal establishment of a new species.
Affinity and other occurrences. Similar grains have not been observed from other mesofossil floras in Portugal.

\section{Piercipollis sp. 2 \\ Text-fig. $42 \mathrm{~d}-\mathrm{f}$}

Description and remarks. Piercipollis sp. 2 is based on isolated pollen grains that occur in a coprolite with other kinds of pollen. Pollen grains of Piercipollis sp. 2 are small, about $12-13 \mu \mathrm{m}$ in diameter, and monocolpate. The colpus is long, extending to the equator. The exine is semitectate-reticulate and columellate (Text-fig. 42d-f). The reticulum is coarse, homobrochate, with lumina up to about $0.15 \mu \mathrm{m}$ in diameter that have polygonal to rounded irregular outlines (Text-fig. 42f). The muri are smooth with slightly rounded profiles and are supported by long scattered columellae. The colpus has a distinct margin formed by the continuing marginal muri. The reticulum detaches easily from the foot layer and the body of the grain delimited by the foot-layer is much smaller than the reticulum (Text-fig. 42f).

Affinity and other occurrences. Similar grains have not been observed from other mesofossil floras in Portugal.

\section{Genus Kempia E.M.Fris, P.R.Crane et K.R.Pedersen gen. nov.}

Type. Designated here. Kempia longicolpites E.M.Fris, P.R.Crane et K.R.PEDERSEN gen. et sp. nov.

Plant Fossil Names Registry Number. PFN000479 (for new genus).

E ty m o l o g y. In honor of the Australian palynologist Elizabeth M. Truswell (also known as Elizabeth M. Kemp) in recognition of her important contribution to Cretaceous palynology.

Diagnosis. Anther dithecate, tetrasporangiate, narrowly elliptical. Pollen small, almost circular in equatorial outline, monocolpate, Colpus extending beyond the full length of the grains, but not dividing the grain into two halves. Exine semitectate-reticulate and columellate. Reticulum heterobrochate with irregular lumina and muri with occasional open ends. Muri smooth with slightly rounded profiles, supported by short, scattered columellae. Colpus margin distinct with reticulum continuing to the margin and the colpus margin delimited by the continuous marginal muri of the reticulum.

Comments on the genus. Pollen grains of Kempia are similar to those of Retimoncolpites dividuus described by Pierce (1961) in having a very long colpus extending beyond the equator, but the grains are much smaller and the colpus does not divide the grain in two halves as in $R$. dividuus. The grains are also similar to those of Piercipollis in several respects (above), including the very loose reticulum, the long columellae and the distinct colpus margin formed from the marginal muri. However, pollen grains of Kempia differ from those of Piercipollis in their heterobrochate reticulum and their more extended colpus. 

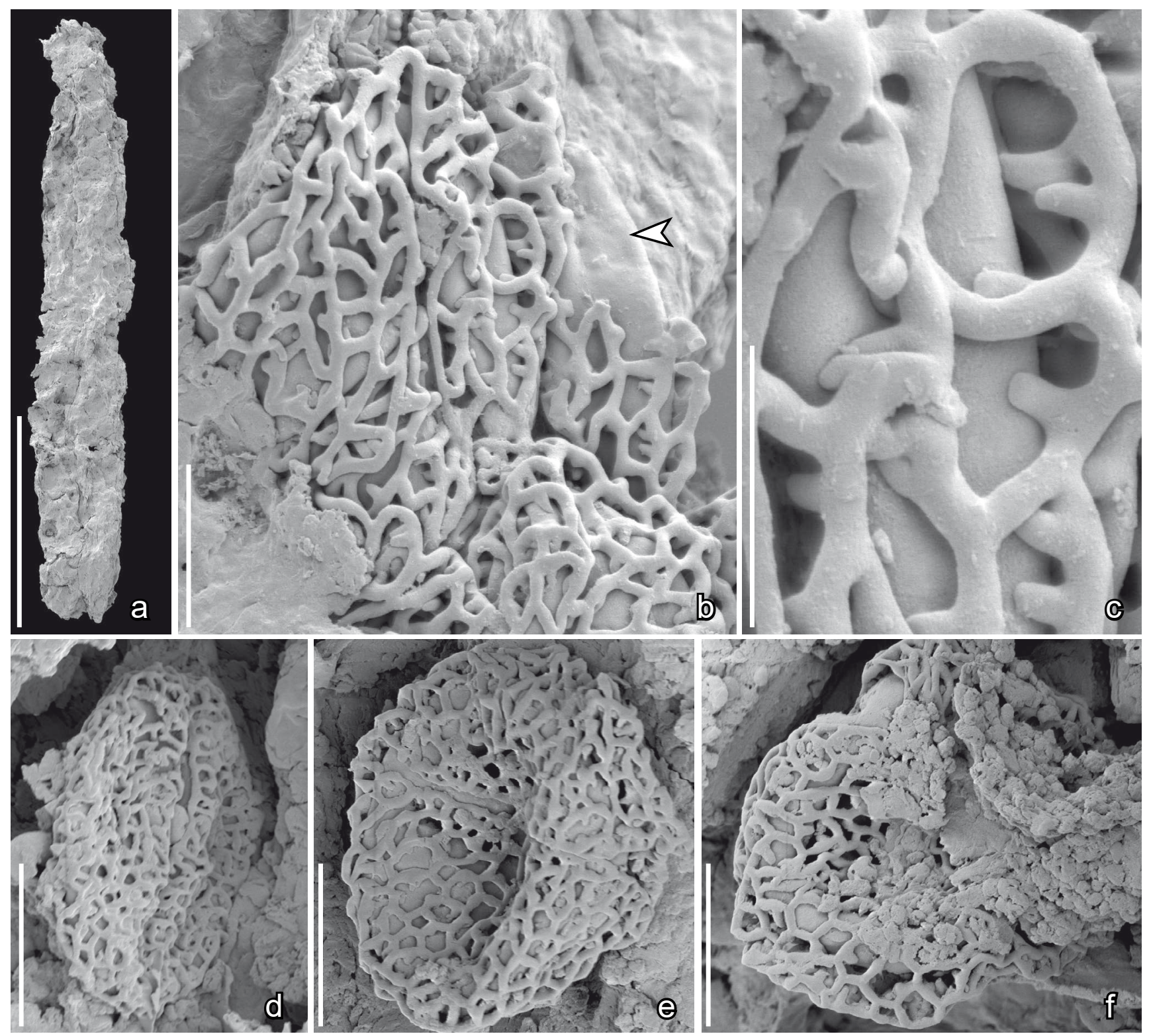

Text-fig. 42. Scanning electron microscope (SEM) images of monocolpate pollen of Piercipollis sp. 1 (a-c) from an isolated anther and Piercipollis sp. 2 (d-f) from a coprolite (not shown); Torres Vedras locality, Portugal. a) Narrow elongate anther that yielded the pollen in (b) and (c); b) Distal view of pollen grain showing well-developed reticulum that is only loosely attached to the foot layer; note the smooth foot layer (arrowhead) of a grain from which the reticulum has become detached; c) Reticulum showing the smooth muri and long columellae that are mostly detached from the foot layer; d-f) Pollen grains in distal (d, e), and lateral views (f) showing the very long colpus and the well-developed reticulum only loosely attached to the smooth surface of the foot layer; note the main body of the grains (foot layer) does not fill out the whole space of the reticulum (f). Specimens, TV44-S148218 (a-c), TV142-S170216 (d-f). Scale bars $300 \mu \mathrm{m}$ (a), $6 \mu \mathrm{m}$ (b, d-f), $3 \mu \mathrm{m}$ (c).

\section{Kempia longicolpites E.M.FriIS, P.R.CRANE et K.R.Pedersen sp. nov. \\ Text-fig. 43a-f}

Ho l o t y p e. Designated here. S105018 (Torres Vedras sample 44; figured Text-fig. 43a-f).

Plant Fossil Names Registry Number. PFN000480 (for new species).

Re p o s i t o ry. Palaeobotanical Collections, Department of Palaeobiology, the Swedish Museum of Natural History, Stockholm, Sweden.

E t y m o log y. From Latin: longus and colpus referring to very long colpus of the pollen grains.
Type locality. Torres Vedras (NE of Forte de Forca; $39^{\circ} 06^{\prime} 13^{\prime \prime} \mathrm{N}, 9^{\circ} 14^{\prime} 47^{\prime \prime} \mathrm{W}$ ).

Type stratum and age. Lower member of the Almargem Formation; Early Cretaceous (late Barremianearly Aptian).

Di a g n o s is. As for the genus.

Dimensions. Length of anther: $0.6 \mathrm{~mm}$; width of anther: $0.25 \mathrm{~mm}$. Length of pollen grains: about $11 \mu \mathrm{m}$.

Description and remarks. Kempia longicolpites is based on a single stamen fragment from Torres Vedras that has a dithecate, tetrasporangiate, anther containing abundant pollen. The species is also known from 

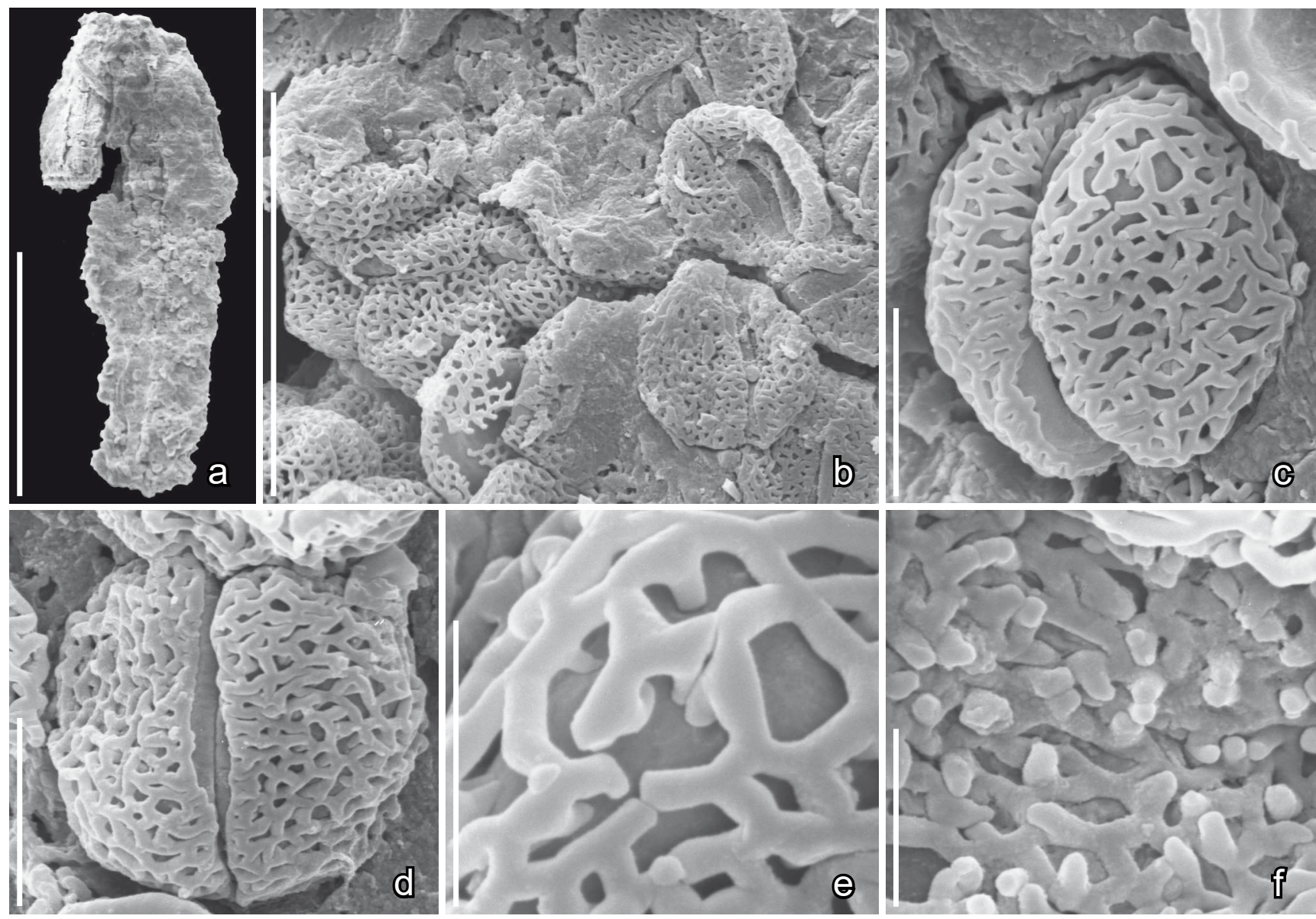

Text-fig. 43. Scanning electron microscope (SEM) images of monocolpate pollen of Kempia longicolpites gen. et sp. nov. from a fragmentary stamen; Torres Vedras locality, Portugal. a) Holotype; stamen fragment showing elongated pollen sacs that yielded the pollen in this Text-figure; b) Pollen grains showing the very long distal aperture and loosely attached reticulum; c, d) Pollen grains showing the very long, clearly defined distal aperture that extends around the ends of the grain; e) Reticulum in nonapertural region showing the smooth muri loosely attached to the smooth surface of the foot layer by short columellae; f) Internal view of reticulum showing the short columellae loosened from the foot layer. Specimen, TV44-S105018 (holotype). Scale bars $300 \mu \mathrm{m}$ (a), $30 \mu \mathrm{m}$ (b), $6 \mu \mathrm{m}$ (c, d), $3 \mu \mathrm{m}$ (e, f).

two adhering stamens with tetrasporangiate anthers from the Catefica locality (S101208). The anther is narrowly elliptical (Text-fig. 43a). Pollen grains are small, almost circular in equatorial outline, and monocolpate. They were figured in an earlier publication as Pollen type D.6 (Friis et al. 1999). The colpus extends beyond the full length of the grains, but does not divide the grain into two halves. The exine is semitectate-reticulate and columellate (Text-fig. 43b-d). The reticulum is heterobrochate with larger, irregular lumina and smaller angular lumina. The muri are smooth with a slightly rounded profile and occasional open ends (Text-fig. 43e). The muri are supported by short, scattered columellae that loosen very easily from the foot layer (Text-fig. 43e, f). The foot layer is thicker than the reticulum and columellae, and the endexine is well-developed only under the aperture (seen in the Catefica specimen). The colpus margin is distinct, with the reticulum continuing to the colpus margin, which is clearly delimited by the continuing marginal muri.

Affinity and other occurrences. Other than the specimens from Torres Vedras and Catefica, Kempia longicolpites has not been encountered in any other mesofossil flora in Portugal. The systematic affinity of the new taxon among non-eudicot angiosperms is not known.

\section{Genus Juhaszia E.M.FriIs, P.R.Crane et K.R.Pedersen gen. nov.}

Type. Designated here. Juhaszia portugallica E.M.Fris, P.R.Crane et K.R.Pedersen gen. et sp. nov.

Plant Fossil Names Registry Number. PFN000481 (for new genus).

E ty m o l o g y. In honor of the Hungarian palynologist Miklós Juhász in recognition of his important contribution to Cretaceous palynology.

D i a g n o s i s . Pollen small, almost circular in equatorial outline, monocolpate. Colpus extending for the full length of the grains. Exine semitectate-reticulate and columellate. Reticulum heteropolar and heterobrochate; microreticulate on the proximal face with lumina on distal face only slightly smaller than lumina in the equatorial region. Muri smooth with slightly rounded profile, supported by short, scattered columellae. Colpus margin distinct, formed by the continuing marginal muri of the adjacent reticulum, which is characterized by a line of smaller lumina.

Comments on the genus. Pollen of Juhaszia is similar to that of Similipollis GóczÁN et JuHÁsz in 
having a long colpus and a graded reticulum. However, in Similipollis the lumina on the distal face are smaller than those on the proximal face, while in Juhaszia the lumina on the proximal face are smaller than those on the distal face. Grains of Similipollis are also considerably larger than those of Juhaszia.

\section{Juhaszia portugallica E.M.FrIIS, P.R.CRANE et K.R.Pedersen sp. nov. Text-fig. 44a-e}

H o l o ty p e. Designated here. S136671 (Torres Vedras sample 44; figured Text-fig. 44a-e).

Plant Fossil Names Registry Number. PFN000482 (for new species).

R e p o s it ory. Palaeobotanical Collections, Department of Palaeobiology, the Swedish Museum of Natural History, Stockholm, Sweden.

Etymology. From Portugal where the fossils were discovered.

Type locality. Torres Vedras (NE of Forte de Forca; 39 $06^{\prime} 13^{\prime \prime} \mathrm{N}, 9^{\circ} 14^{\prime} 47^{\prime \prime} \mathrm{W}$ ).

Type stratum and age. Lower member of the Almargem Formation; Early Cretaceous (late Barremianearly Aptian).

Di a g nos is. As for the genus.

Dimensions. Length of pollen grains: about 23$24 \mu \mathrm{m}$.

De s cription and remarks. Pollen of Juhaszia portugallica occurs in an elongate clump composed of a single kind of pollen grain, and may be a fragment of an anther, or perhaps a coprolite (Text-fig. 44a). The pollen grains are small, almost circular in equatorial outline, and monocolpate. The colpus is long, extending for the full length of the grains. The exine is semitectate-reticulate and columellate (Text-fig. 44b-e). The reticulum is heteropolar and heterobrochate. Lumina are largest in the equatorial region and decrease in size towards the proximal pole where the reticulum is microreticulate (Text-fig. 44b). On the distal face lumina are only slightly smaller than lumina in the equatorial parts of the grains, but are smaller close to the colpus margin. The muri are smooth with a slightly flattened to rounded profile and are supported by short, scattered columellae (Text-fig. 44c). The colpus margin is distinct with the reticulum continuing to the margin, and the margin formed by the continuing marginal muri. The reticulum loosens easily from the foot layer and several naked grains, which expose the smooth surface of the foot layer, are present in the pollen clump (Text-fig. 44e).

Affinity and other occurrences. Subtle grading of the reticulum into finer regions at the distal pole is known for pollen grains described from the Potomac Group sediments (Walker and Walker 1986) and has been used to compare the fossil grains with pollen of extant monocots. The grains from the Potomac Group differ from those of Juhaszia portugallica in their finer reticulum and very short columellae. Grains of Juhaszia portugallica also show some similarity to grains assigned to the genus Similipollis, but pollen of these two genera differs in the pattern of the grading (see Comments on the genus). Grading of the reticulum that forms a microreticulate-foveolate region at the proximal pole is also know for the pollen associated with Anacostia E.M.FriIs, K.R.Pedersen et P.R.CRANE, but Anacostia pollen grains are trichotomocolpate and also have a microreticulate-foveolate zone bordering the aperture.

\section{Genus Dictyozonia E.M.Fris, P.R.Crane et K.R.PEDERSEn gen. nov.}

Ty p e. Designated here. Dictyozonia pusilla E.M.FriIs, P.R.Crane et K.R.Pedersen gen. et sp. nov.

Plant Fossil Names Registry Number. PFN000522 (for new genus).

E ty m o log y. From Greek diktyotó for reticulum and zoni for belt or girdle referring to the reticulate equatorial band of the pollen grains.

Di a g n o s is. Stamen tetrasporangiate. Pollen small, almost circular in equatorial outline, monocolpate. Colpus extending for the full length of the grain. Exine semitectatereticulate in the equatorial region, psilate to psilatepunctate in polar regions. Pollen columellate, reticulum heterobrochate grading into the psilate regions near the poles. Muri smooth with a slightly rounded profile, supported by short, scattered columellae. Colpus margin distinct. Colpus membrane verrucate.

Comments on the genus. Pollen of Dictyozonia is similar to that of Similipollis and Juhaszia in having a long colpus and a graded reticulum, but pollen of Dictyozonia differs from both taxa in the very distinctive reticulate equatorial band and the broad psilate zone on both the proximal and distal faces of the grains.

\section{Dictyozonia pusilla E.M.Fris, P.R.Crane et K.R.Pedersen sp. nov. Text-fig. $44 \mathrm{f}-\mathrm{k}$}

H o l o t y p e. Designated here. S105002 (Torres Vedras sample 144; figured Text-fig. 44f-k).

Plant Fossil Names Registry Number. PFN000523 (for new species).

R e p o s i t ory. Palaeobotanical Collections, Department of Palaeobiology, the Swedish Museum of Natural History, Stockholm, Sweden.

Etymology. From Latin: pusillus, very small, referring to the very small size of the pollen grains.

Type locality. Torres Vedras (NE of Forte de Forca; $39^{\circ} 06^{\prime} 13^{\prime \prime} \mathrm{N}, 9^{\circ} 14^{\prime} 47^{\prime \prime} \mathrm{W}$ ).

Type stratum and age. Lower member of the Almargem Formation; Early Cretaceous (late Barremianearly Aptian).

D i a g n o s is. As for the genus.

Dimensions. Diameter of pollen grains: about 9-12 $\mu \mathrm{m}$. 

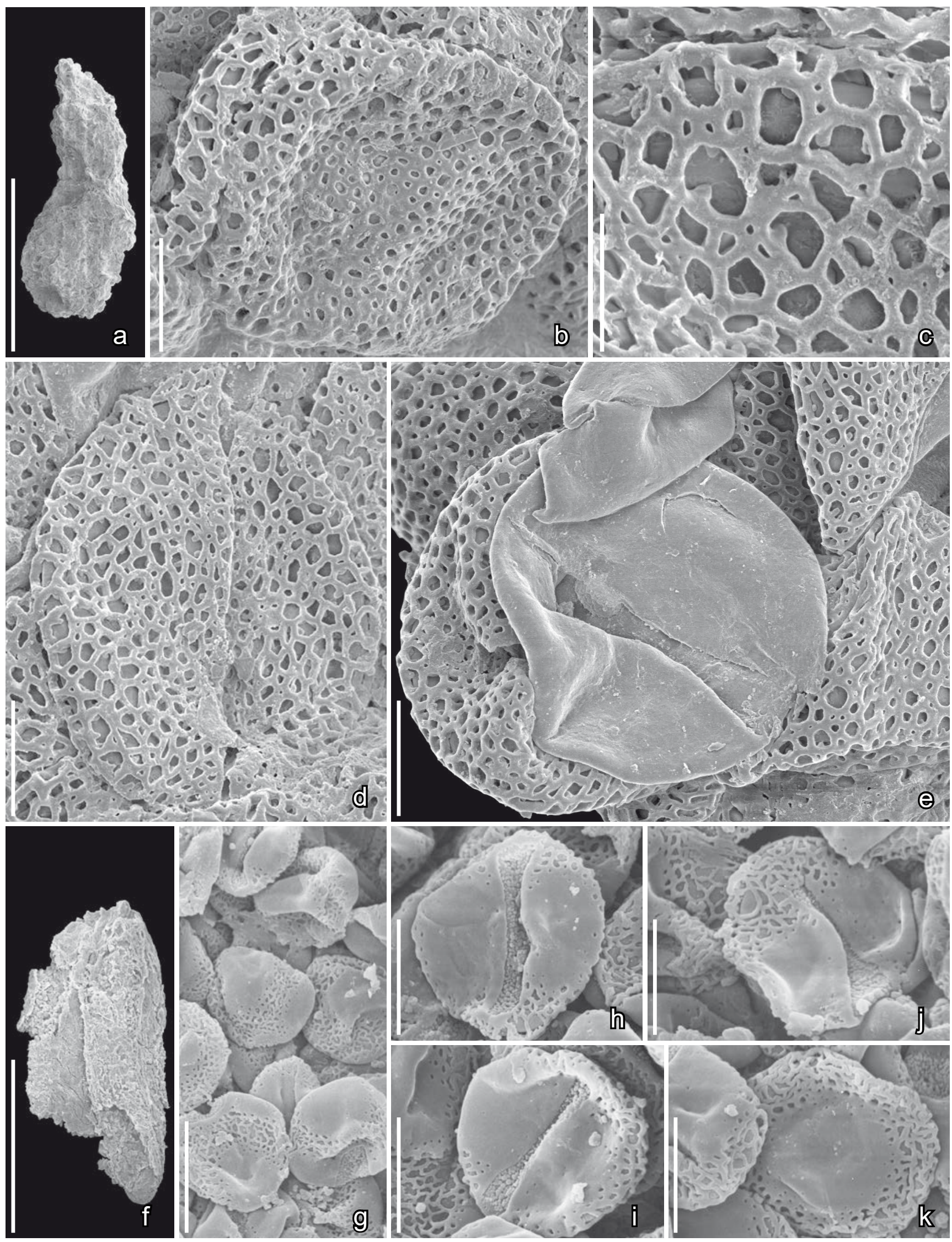

Text-fig. 44. Scanning electron microscope (SEM) images of monocolpate pollen of Juhaszia portugallica gen. et sp. nov. from a fragment of a pollen sac (a-e) and stamen fragment and pollen of Dictyozonia pusilla gen. et sp. nov. (f-k); Torres Vedras locality, Portugal. a) Holotype; fragment of pollen sac that yielded the pollen in (b-e); b) Proximal surface of pollen grain showing reticulate sculpture in the equatorial regions grading into more a continuous foveolate tectum at the proximal pole; c) Reticulum on the proximal surface showing smooth muri delimiting large and small luminae. Muri supported by numerous short columellae that are only loosely attached to the smooth surface of the foot layer; d) Distal surface of pollen grain showing the long colpus and reticulate sculpture with a distinctive pattern of large and small luminae; e) Pollen grain from which the reticulum has become 
Description and remarks. The species is based on a fragment of a tetrasporangiate stamen (Text-fig. $44 \mathrm{f}$ ) with pollen in situ (Text-fig. 44g-k). The pollen grains were briefly described and illustrated earlier as pollen type "B.4 monocolpate, psilate-reticulate pollen" (Friis et al. 1999), but the material was not formally named. The pollen grains are small, almost circular in equatorial outline, and monocolpate. The pollen wall is semitectate-reticulate in the equatorial region, and psilate to psilate-punctate in the polar regions (Text-fig. $44 \mathrm{~g}-\mathrm{k}$ ). The reticulum forms a distinct band around the equator (Text-fig. $44 \mathrm{~g}, \mathrm{k}$ ). The reticulum is heterobrochate with a narrow microreticulate to foveolate zone bordering the psilate regions of the distal and proximal poles. In the polar regions the tectum is psilate with a narrow punctate zone close to the colpus margin (Text-fig. $44 \mathrm{j}$ ). Muri are smooth with slightly rounded profile, and are supported by short, scattered columellae. The colpus extends for the full length of the grains and has a distinct margin and verrucate membrane (Text-fig. 44h-j).

Affinity and other occurrences. Dictyozonia pusilla is only known from the Torres Vedras mesofossil flora. A probably related pollen type with psilate polar regions and a semitectate equatorial region was observed in a small flower fragment from the Buarcos mesofossil flora (Pollen Type B.3 in Friis et al. 1999). However, in the Buarcos specimen both monocolpate and trichotomocolpate pollen occur in the same anther and the tectum in the equatorial region is microreticulate to foveolate. Pollen grains with extended psilate polar regions and reticulate equatorial regions have been described from the Early Cretaceous of the Potomac Group by Walker and Walker (1986) who suggested an affinity for these grains with extant monocots, but so far we have been unable to place Dictyozonia pusilla in any modern taxon.

Very small pollen grains somewhat comparable to those of Dictyozonia pusilla with a graded reticulum and foveolate to psilate proximal face were also described from the Albian of Egypt as Reticoll-Smallpatch and CrochetretBaldap (Penny 1991), but none of these has a similar narrow reticulate equatorial band and psilate areas on the distal face.

\section{Genus Dinisia E.M.FriIs, P.R.Crane et K.R.Pedersen gen. nov.}

Ty p e . Designated here. Dinisia portugallica E.M.FriIS, P.R.CRANe et K.R.PEDERSEn gen. et sp. nov.

Plant Fossil Names Registry Number. PFN000483 (for new genus).

Ety mology. In honor of the Portuguese geologist Jorge Dinis in recognition of his important contribution to the Cretaceous geology of Portugal.

Diagnosis. Anther dithecate and tetrasporangiate. Pollen small, elliptical to almost circular in equatorial outline, monocolpate. Colpus short. Exine semitectate-reticulate and columellate. Reticulum homobrochate, vermiform; lumina of irregular shape. Muri of irregular width, supported by long, scattered columellae. Colpus margin indistinct. Colpus membrane with a fragmented reticulum. Orbicules small, spherical.

Comments on the genus. Pollen grains of Dinisia are distinguished from other Early Cretaceous pollen grains with a reticulate pollen wall and smooth muri mainly by the short colpus, the irregular muri, the diffuse colpus margin, and the colpus membrane covered by a fragmentary reticulum. In their diffuse colpus margin and partly reticulate colpus membrane the grains are similar to some of the grains assigned to Clavatipollenites (e.g. Textfig. 23), but these are characterized by muri with supratectal ornamentation of small spines or verrucae.

\section{Dinisia portugallica E.M.Fris, P.R.CrAnE et K.R.PEDERSEN sp. nov. Text-fig. $45 \mathrm{a}-\mathrm{e}$}

H o l o t y p e. Designated here. S148216 (Torres Vedras sample 44; figured Text-fig. 45a-e).

Plant Fossil Names Registry Number. PFN000484 (for new species).

\section{P a r a t y p e. S148217 (Torres Vedras sample 44).}

R e p o s i t ory. Palaeobotanical Collections, Department of Palaeobiology, the Swedish Museum of Natural History, Stockholm, Sweden.

Etymology. From Portugal where the fossils were discovered.

Type locality. Torres Vedras (NE of Forte de

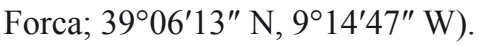

Type stratum and age. Lower member of the Almargem Formation; Early Cretaceous (late Barremianearly Aptian)

Di a g n o s is. As for the genus.

D i m e n s i o n s . Length of anther: $0.75 \mathrm{~mm}$; width of anther: $0.18 \mathrm{~mm}$. Length of pollen grains: about 17-20 $\mu \mathrm{m}$.

Description and remarks. The anthers are dithecate and tetrasporangiate, narrowly elliptical in outline and broken near the base (Text-fig. 45a). Additional grains were also found in a pollen clump, possibly a coprolite, together with several other kinds of pollen. Pollen grains found in situ are small, about 17-20 $\mu \mathrm{m}$ long, elliptical to almost circular in equatorial outline and monocolpate. The colpus is short. The exine is semitectate-reticulate and columellate (Text-fig. 45b-e). The reticulum is homobrochate, with irregular vermiform muri of irregular width delimiting lumina of irregular shape and size. The

detached showing the long colpus and the smooth surface of the foot layer; f) Holotype; fragment of stamen that yielded the pollen in $(\mathrm{g}-\mathrm{k}) ; \mathrm{g})$ Cluster of pollen grains in proximal and distal views showing the distinctive equatorial reticulum and psilate distal and proximal regions; $\mathbf{h}-\mathbf{j}$ ) Distal views of pollen grains showing the equatorial reticulum and long colpus with verrucate colpus membrane; k) Proximal view of pollen showing the psilate polar region. Specimens, TV44-S136671 (holotype; a-e), TV144-S105002 (holotype; f-k). Scale bars $300 \mu \mathrm{m}$ (a, f), $10 \mu \mathrm{m}(\mathrm{g}), 6 \mu \mathrm{m}$ (b, d, e, h-k), $6 \mu \mathrm{m}$ (b, d, e, h-k), $3 \mu \mathrm{m}$ (c). 
columellae are long and scattered under the muri. The colpus has an indistinct margin and a colpus membrane covered by a fragmented reticulum (Text-fig. 45b, e). The inner surface of the anther wall is covered by densely spaced orbicules that are small, spherical and have an uneven surface (Textfig. $45 \mathrm{c}-\mathrm{e})$.

Affinity and other occurrences. Similar grains have not been observed from other mesofossil floras.

\section{Genus Teebacia E.M.FriIS, P.R.Crane et K.R.Pedersen} gen. nov.
Ty p e. Designated here. Teebacia hughesii E. M. FriIs, P. R. Crane et K. R. Pedersen gen. et sp. nov.

Plant Fossil Names Registry Number. PFN000485 (for new genus).

Etymology. From the informal name Barremianteebac given to similar grains from the Barremian of southern England by Norman F. Hughes.

D i a g n o s is . Anthers narrowly elliptical and flattened, dithecate and tetrasporangiate. Pollen small, almost circular in equatorial outline, monocolpate. Colpus long. Exine
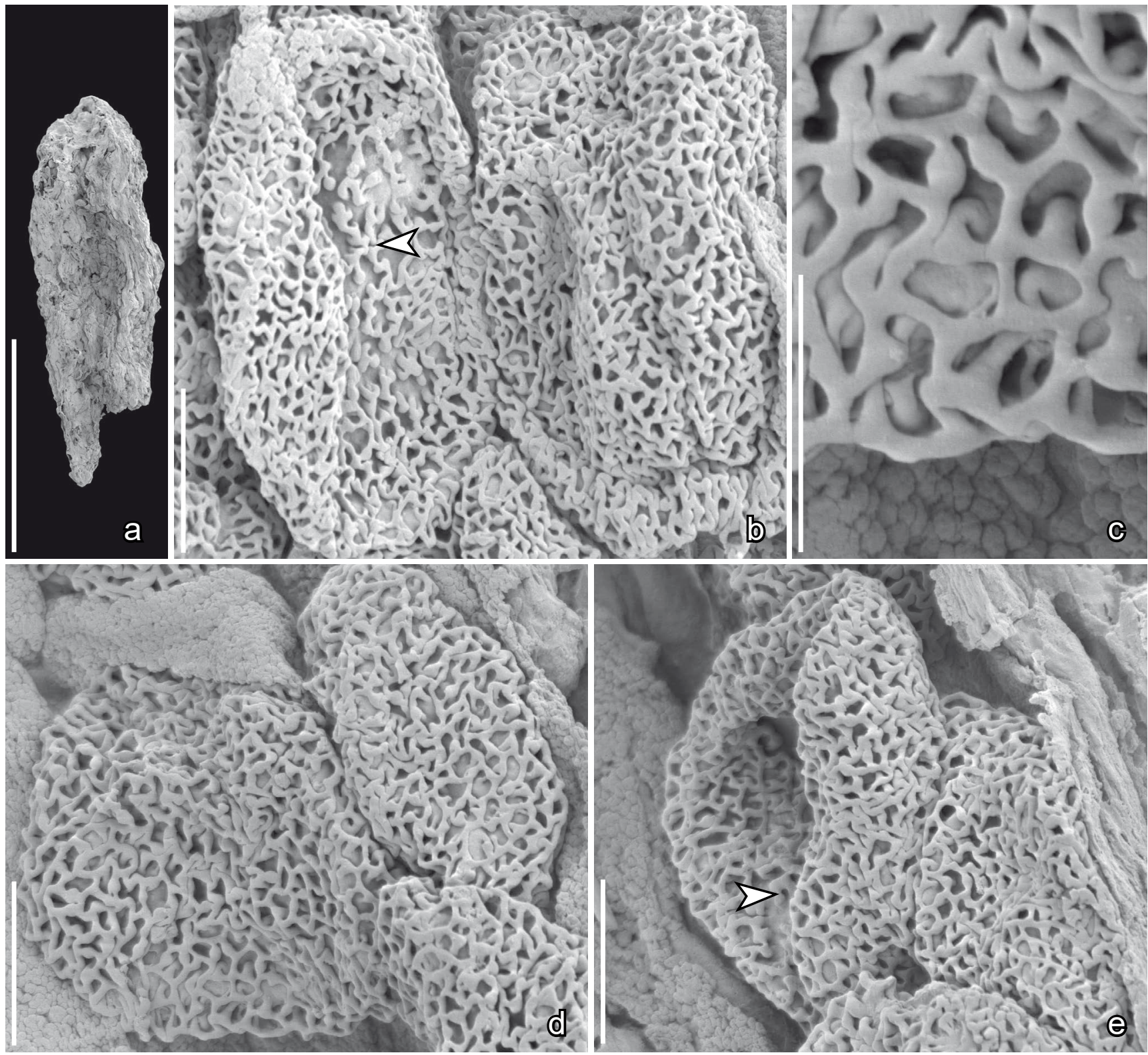

Text-fig. 45. Scanning electron microscope (SEM) images of monocolpate pollen of Dinisia portugallica gen. et sp. nov. from a fragmentary stamen; Torres Vedras locality, Portugal. a) Holotype; stamen fragment showing elongated pollen sacs that yielded the pollen in this Text-figure; b) Two pollen grains showing poorly defined distal aperture (arrowhead) and distinctive vermiform reticulum forming luminae of variable shapes and sizes; note especially the irregularly and incomplete reticulum in the grain on the left; c) Reticulum showing smooth, vermiform muri attached to the smooth surface of the foot layer by long columellae; note that columellae often terminate segments of muri that are not closed; d, e) Pollen grains showing proximal surface (d), poorly defined distal aperture (e, arrowhead) and distinctive vermiform reticulum supported by long columellae; note dense covering of small, spherical orbicules on the inner surface of the anther wall. Specimen, TV44-S148216 (holotype). Scale bars $300 \mu \mathrm{m}$ (a), $6 \mu \mathrm{m}(\mathrm{b}, \mathrm{d}, \mathrm{e}), 3 \mu \mathrm{m}(\mathrm{c})$. 
semitectate-reticulate and columellate. Reticulum coarse, heterobrochate with lumina of various sizes. Muri with a supratectal ornamentation of narrow ridges perpendicular to the length of the muri. Underside of muri granular. Muri supported by long, scattered columellae. Colpus margin distinct formed by the fused marginal muri.

Comments on the genus. Pollen grains of Teebacia are distinguished from all other reticulate pollen described here by the supratectal ornamentation of densely arranged, narrow ridges. Similar grains from the Barremian of Southern England were informally referred to as CfA Barremian-teebac by Hughes (1994) and Retisulc-Cand(Teebac) (Hughes et al. 1979). Comparable grains from many other Early Cretaceous palynofloras are typically assigned to the genus Retimonocolpites. For example, Retimonocolpites muristriatus J.H.J.PENNY from the late Barremian of Egypt (Penny 1986) is very similar to pollen of Teebacia hughesii but is larger and the reticulum appears more dense. However, Retimonocolpites sensu stricto is characterized by the very long encircling colpus and apparently smooth muri. Comprehensive revision would require that Retimonocolpites muristriatus and similar species be transferred to Teebacia.

\section{Teebacia hughesii E.M.Fris, P.R.Crane et K.R.Pedersen sp. nov. Text-fig. 46a-f}

H o l o ty p e. Designated here. S136666 (Torres Vedras sample 44; figured Text-fig. 46a, d, e).

Plant Fossil Names Registry Number. PFN000486 (for new species).

P a r a types. Designated here. S105017, S136665, S136667, S136670, S136674, S136675, S137915, S137916, S149206, S149207, S174560 (Torres Vedras sample 44).

Rep o s i t ory. Palaeobotanical Collections, Department of Palaeobiology, the Swedish Museum of Natural History, Stockholm, Sweden.

Etymology. In honor of the British palynologist Norman F. Hughes in recognition of his important contribution to Cretaceous palynology and studies of angiosperm evolution.

Type locality. Torres Vedras (NE of Forte de Forca; $\left.39^{\circ} 06^{\prime} 13^{\prime \prime} \mathrm{N}, 9^{\circ} 14^{\prime} 47^{\prime \prime} \mathrm{W}\right)$.

Type stratum and age. Lower member of the Almargem Formation; Early Cretaceous (late Barremianearly Aptian).

Di a g nos is. As for the genus.

Dimensions . Length of anther: $0.45 \mathrm{~mm}$; width of anther: $0.18 \mathrm{~mm}$. Length of pollen grains: about $18 \mu \mathrm{m}$.

Description and remarks. Teebacia hughesii is based on many isolated anthers with pollen in situ. The anthers are narrowly elliptical in outline, dithecate and tetrasporangiate (Text-fig. 46a). Anthers and pollen were briefly described and illustrated earlier (Friis et al. 2010a, b), but not formally named. Pollen grains found in situ within the anthers are small, about $18 \mu \mathrm{m}$ long, almost circular in equatorial outline and monocolpate. The colpus is long extending for the full length of the grain. The exine is semitectate-reticulate and columellate (Text-fig. 46e, f). The reticulum is coarse, heterobrochate with lumina of various sizes (Text-fig. 46b-f). The muri have a rounded profile and on their upper side they are ornamented with densely spaced, narrow, transverse ridges (Text-fig. 46c, d). The underside of the muri is finely granular (Text-fig. 46b). The muri are supported by long, scattered columellae with a granular surface (Text-fig. 46c). The colpus margin is distinctly delimited by fused marginal muri (Text-fig. 46e, f). Orbicules are densely distributed on the inner surface of the anther wall and are also scattered among pollen grains. The orbicules are small, spherical with a shallow depression (Text-fig. 46d).

Affinity and other occurrences. Pollen referable to Teebacia has also been recorded from the Vale de Água mesofossil flora with three different types, probably belonging to three different species. These three different types were described and illustrated as Pollen Type I.1, I.2 and I.3 (Friis et al. 1999). They are all smaller than the Torres Vedras specimens (I.1: 13-14 $\mu \mathrm{m}$; I.2: 12-14 $\mu \mathrm{m}$; I.3: $10-11 \mu \mathrm{m})$ and differ in having transverse ridges that are coarser. Grains of type I.3 are found in situ in an anther with larger, tooth-like orbicules different from the small spherical orbicules that line the inner anther walls of Teebacia hughesii.

Similar pollen are also reported from many palynofloras (see Comments on the genus) and have been referred to several different species. Pollen from the Barremian of southern England referred to as CfA Barremian-teebac (Hughes 1994) and Retisulc-Cand(Teebac) (Hughes et al. 1979) has very fine transverse ridges similar to those of the Torres Vedras specimens.

\section{Reticulate-foveolate pollen Text-fig. $47 \mathrm{a}-\mathrm{d}$}

Description and remarks. Two apparently monocolpate pollen grains with a characteristic reticulatefoveolate tectum were found on the surface of a fruit of Serialis antiqua. Both grains are preserved with the nonapertural face exposed (Text-fig. 47a, b). The grains are angular to almost circular in equatorial view, about 17$22 \mu \mathrm{m}$ in diameter. The lumina-foveae are small, rounded and decrease in size towards the presumed proximal pole. The tectum surrounding the perforations is ornamented by small indistinct ridges that are irregularly arranged and form a braided pattern (Text-fig. 47b, d).

Affinity and other occurrences. We have not observed other pollen grains with a similar braided ornamentation in other Early Cretaceous mesofossil floras and the grains most likely represent a new taxon. However, because the aperture configuration is unknown the grains are not formally named here. We think it unlikely that these grains were produced by the Serialis plant. They are distinct from the reticulate grains that occur in clusters on the stigmatic surface of Serialis fruits that are more probably the pollen grains produced by the Serialis plant (Friis et al. 2019a). 

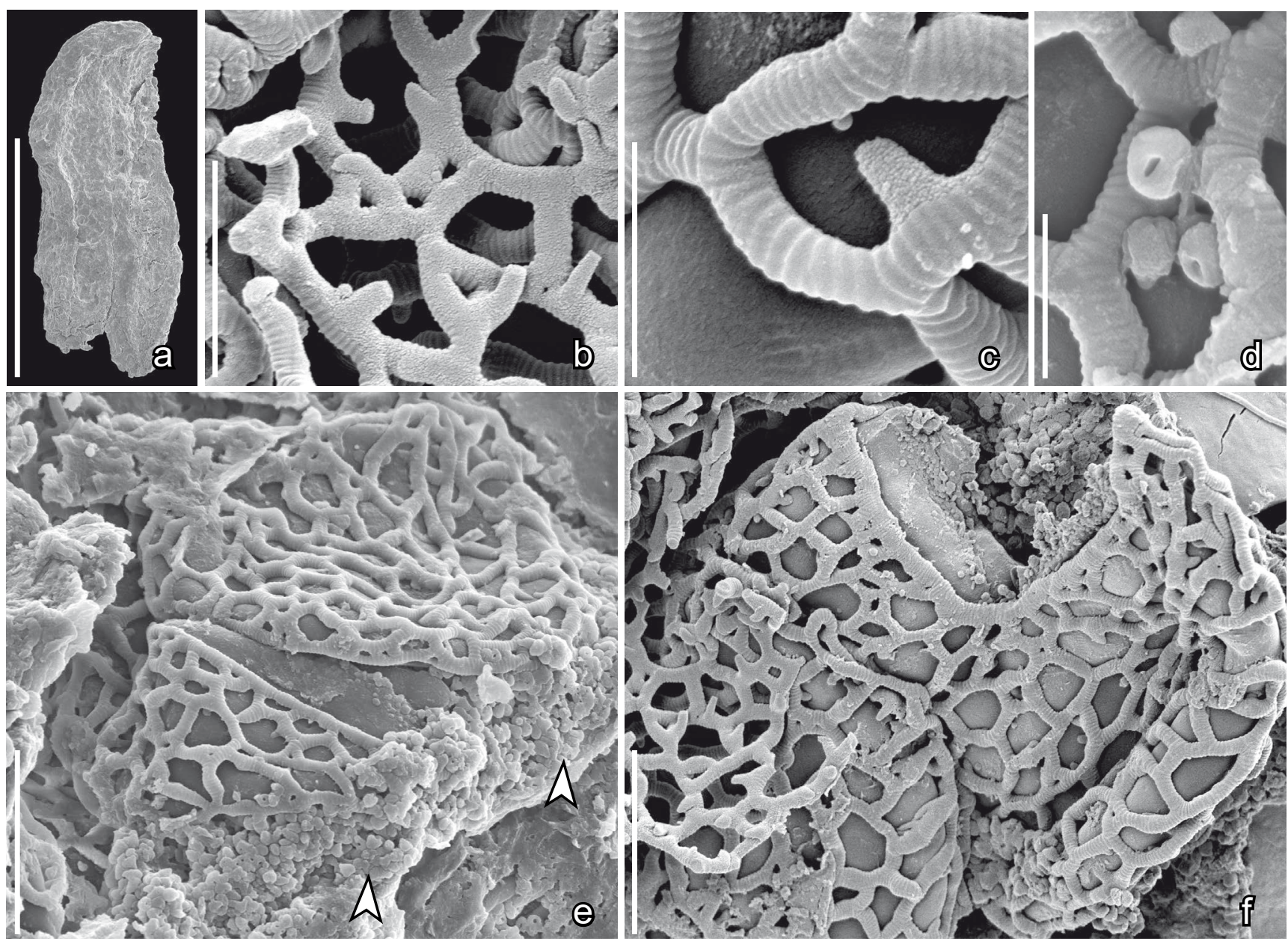

Text-fig. 46. Scanning electron microscope (SEM) images of monocolpate pollen of Teebacia hughesii gen. et sp. nov. pollen from a stamen fragment; Torres Vedras locality, Portugal. a) Holotype; stamen fragment showing elongated pollen sacs that yielded the pollen in this Text-figure (d, e); b) Detail of detached reticulum showing inner surface of muri and scattered columellae; note the finely granular covering of the muri and columellae; $c$, d) Detail of reticulum showing the outer surface of muri with supratectal ornamentation of narrow ridges; note orbicules attached to the reticulum (d); e, f) Pollen grains showing loose, beaded, reticulum with long columellae; note continuous muri bordering the apertures and densely spaced minute orbicules lining the inner surface of the anther wall (e, arrowheads). Specimens, TV44-S136666 (holotype; a, d, e), TV44-S149207 (b, c, f). Scale bars $300 \mu \mathrm{m}$ (a), $6 \mu \mathrm{m}(\mathrm{e}, \mathrm{f}), 3 \mu \mathrm{m}$ (b), $1.5 \mu \mathrm{m}$ (c), $1.2 \mu \mathrm{m}$ (d).

\section{Monoaperturate semitectate-reticulate pollen with sharp muri \\ Text-fig. 48a-e}

Description and remarks. Several distinctive semitectate-reticulate pollen grains characterized by a coarse, homobrochate reticulum, high muri with a sharp profile and broad scattered columellae (Text-fig. 48b-e) have been recovered from a coprolite (Text-fig. 48a), where they occur with several other kinds of pollen, including pollen of Goczania inaequalis (Text-fig. 48c-e). In some of the grains, the muri have faintly transverse striae. All the grains are partly covered by other pollen within the coprolite and none of them shows their full size and shape. The aperture configuration is also not visible in any of the specimens and the monoaperturate status not fully documemted. The reticulum is only loosely attached to the main body of the grain by the scatttered columellae and is larger than the main body (Text-fig. 48c, e).

Affinity and other occurrences. Pollen grains with similar coarse reticulum and high, sharp muri are described from the Hauterivian of Southern England as Reticulc-newling (Hughes 1994) and Retimonocolpites sp. 2 from the Barremian of Egypt (Schrank and Mahmoud 2002), but in these grains the columellae are narrower than in the grains from Torres Vedras and the main body of the grain is not much smaller than the reticulum. Similar sharp muri and a coarse reticulum is also characteristic for the pollen of Retimonocolpites larus J.V.WARD described from the Albian of Kansas, USA (Ward 1986).

The pollen grains from the coprolite also resemble pollen of Afropollis J.A.Doyle, S.JARDiné et DoERENKAMP in several respects. Grains of Afropollis have similar high, sharp muri, a reticulum that is larger than the main body of the pollen, and muri with a transversely striate, segmented ornamentation. In most species of Afropollis the muri are strongly segmented and the grains are acolumellate. However, a few species of Afropollis have muri with finer striations and some species have the reticulum supported by columellae, but none of these previously described species of Afropollis is closely similar to the grains described here from Torres Vedras. Provisionally we regard the Torres Vedras grains 


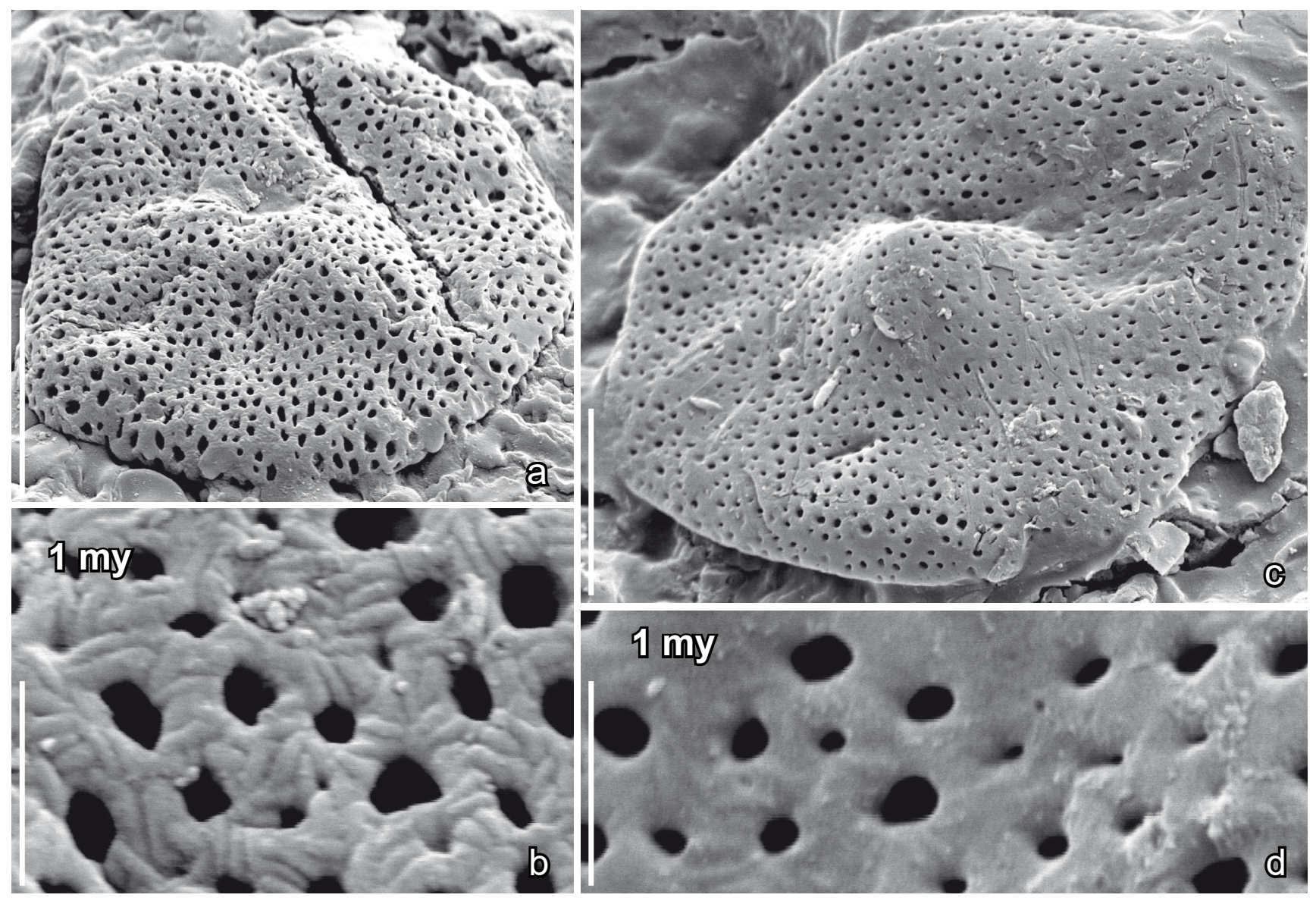

Text-fig. 47. Scanning electron microscope (SEM) images of reticulate-foveolate pollen on the surface of a fruit of Serialis antiquum; Torres Vedras locality, Portugal. a, b) Pollen grain showing angular outline and tectum perforated by foveolae of different sizes; note the braided tectum ornamentation formed by aggregations of small ridges (b); aperture not known; c, d) Pollen grain showing angular outline, tectum perforated by foveolae that become smaller toward the presumed pole; note the relatively smooth tectum and faint pattern of braiding ridges (d); aperture not known. Specimens, TV43-S171535-01 (a, b), TV43-S171535-02 (c, d). Scale bars $6 \mu \mathrm{m}(\mathrm{a}, \mathrm{c}), 1 \mu \mathrm{m}(\mathrm{b}, \mathrm{d})$.

as those of a non-eudicot angiosperm. However, because the assignment of Afropollis to angiosperms is uncertain, and has been questioned based on the presence of a thick laminate endexine and the form of the pollen sac (Friis et al. 1999), we leave open the possibility that these grain may have been produced by an extinct group of non-angiosperm seed plants.

\section{Genus Vedresia E.M.FriIs, P.R.Crane et K.R.Pedersen gen. nov.}

Ty p e. Designated here. Vedresia elliptica E.M.Fris, P.R.CRANe et K.R.Pedersen gen. et sp. nov.

Plant Fossil Names Registry Number. PFN000487 (for new genus).

Etymology. From part of name of Torres Vedras where the fossils were found.

Diagnosis. Fruit small, elliptical in lateral and transverse views, unilocular and apparently one-seeded without remains of hypanthium or stamen scars. Stigma indistinct, sessile. Pollen broadly elliptical to circular in equatorial outline, monocolpate with a long colpus extending for the full length of the pollen. Colpus margin distinct. Semitectate-reticulate, columellate, heterobrochate.
Lumina around colpus margin much smaller than lumina over the rest of the grain. Muri smooth without supratectal ornamentation.

Comments on the genus. Fossil fruits of Vedresia show some similarities to fruits of Canrightiopsis E.M.Fris, G.W.Grimm, M.M.Mendes et K.R.Pedersen described from other Early Cretaceous mesofossil floras from Portugal (Friis et al. 2015b). However, Vedresia lacks the dorsal stamen scars that are characteristic of Canrightiopsis and the associated pollen grains have smooth muri, unlike the beaded muri of pollen associated with Canrightiopsis. Pollen grains associated with Vedresia elliptica also resemble pollen associated with Canrightia, but the pollen grains associated with Vedresia typically have a reticulum with smaller lumina. Vedresia is also distinct from Canrightia in lacking a hypanthium (Friis and Pedersen 2011).

\section{Vedresia elliptica E.M.Fris, P.R.Crane et K.R.Pedersen sp. nov. Text-fig. 49a-c}

H o l o t y p e. Designated here. S136735 (Torres Vedras sample 43; figured Text-fig. 49a-c).

Plant Fossil Names Registry Number. PFN000488 (for new species). 
R e p o s i t ory. Palaeobotanical Collections, Department of Palaeobiology, the Swedish Museum of Natural History, Stockholm, Sweden.

Ety mology. From Latin: ellipticus referring to the elliptical shape of the fruit.

Type locality. Torres Vedras (NE of Forte de Forca; $39^{\circ} 06^{\prime} 13^{\prime \prime} \mathrm{N}, 9^{\circ} 14^{\prime} 47^{\prime \prime} \mathrm{W}$ ).

Type stratum and age. Lower member of the Almargem Formation; Early Cretaceous (late Barremianearly Aptian).

Di a g nos is. As for the genus.

D i m e n s i o n s . Length of fruit: $0.8 \mathrm{~mm}$; width of fruit: $0.6 \mathrm{~mm}$. Long axis of pollen grains parallel with the colpus: about $18 \mu \mathrm{m}$.

Description and remarks. Vedresia elliptica is based on a single fruit that has been studied only by SEM and details of its internal structure are unknown. The fruit is small, elliptical in lateral view, and there is no attachment scar or scars from detached floral organs (Text-fig. 49a). The outline of the fossil strongly suggests that the fruit is unilocular and contains a single seed. Slight irregularities in the fruit surface also suggest that the enclosed seed had an irregular, reticulate surface. There are no clear indications of oil cells in the fruit wall. The stigmatic area is sessile, indistinct and has numerous pollen grains, all of the same kind, adhering to the stigma (Text-fig. 49b). Pollen is broadly elliptical to circular in equatorial outline, and monocolpate with a long colpus that extends for the full length of the grains. Grains are semitectate-reticulate and heterobrochate. Lumina over most of the pollen surface are of various sizes, up to about $1.5 \mu \mathrm{m}$ in diameter. Bordering the colpus margin lumina are smaller and grade into foveae (Text-fig. 49c). Muri are smooth, lack supratectal ornamentation and are supported by long, scattered columellae. The reticulum is only loosely attached to the foot layer and has been lost in several of the grains.

Affinity and other occurrences. The similarities of the Vedresia elliptica fruit and its associated pollen grains to fruits of Canrightiopsis and Canrightia and their associated pollen grains strongly suggest a relationship to the clade comprising extant Ascarina, Chloranthus and Sarcandra, among extant Chloranthaceae. However, information on internal structures including seed coat anatomy is lacking and assignment of Vedresia to the Chloranthales is currently not secure.

Pollen grains associated with Vedresia elliptica are very similar to those of Eckhartia brevicolumella (see p. 210 and Text-fig. 37) and it is possible that they were produced by the same species, or a very similar kind of plant.
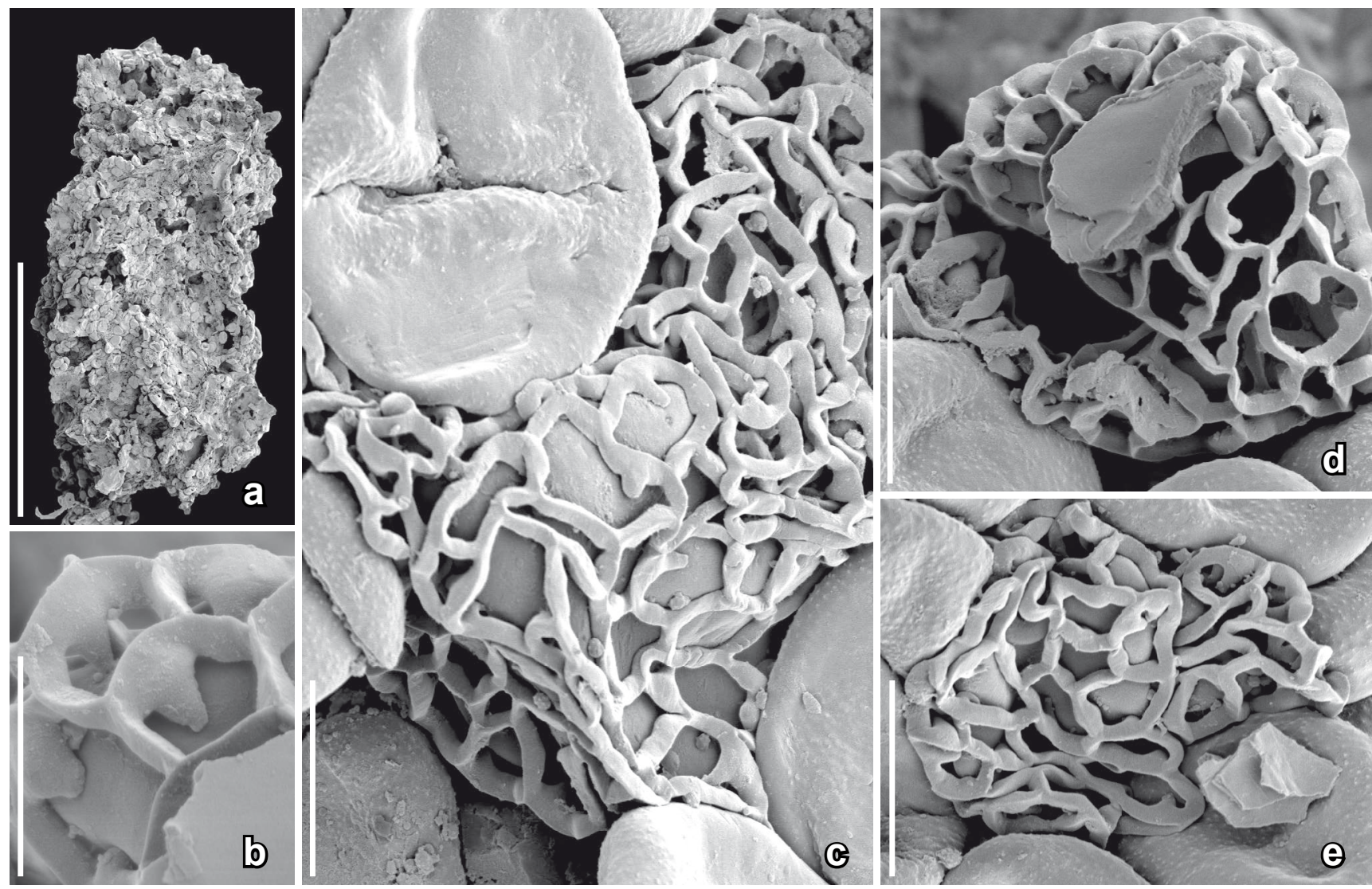

Text-fig. 48. Scanning electron microscope (SEM) images of monocolpate pollen from a coprolite; Torres Vedras locality, Portugal. a) Coprolite that yielded the pollen in this Text-figure as well as several other kinds of pollen; b) Reticulum of pollen grain showing the tall, sharp muri and obconical columellae; c-e) Grains of Goczania inaequalis sp. nov. intermixed with pollen grains that have a coarse, loosely attached reticulum with tall, sharp muri and sparse columellae; note the weak transverse striations on the muri and that the reticulum is much larger than the main body of the grain that it encloses. Specimen, TV44-S148023. Scale bars $300 \mu \mathrm{m}$ (a), $6 \mu \mathrm{m}$ (c-e), $3 \mu \mathrm{m}$ (b). 


\section{Genus Choffaticarpus E.M.FriIs, P.R.Crane et K.R.PEDERSEN gen. nov.}

Type. Designated here. Choffaticarpus compactus E.M.Fris, P.R.Crane et K.R.Pedersen gen. et sp. nov.

Plant Fossil Names Registry Number. PFN000489 (for new genus).

Etym ology. In honor of the French geologist Paul Choffat in recognition of his important contribution to the Cretaceous geology of Portugal.

Diagnosis. Multicarpellate and apocarpous fruit with densely packed fruitlets borne helically on a long central receptacle. Each fruitlet strongly compressed laterally with flattened sides and a diamond-shaped outer face. Stigma sessile, indistinct. Each fruiting unit containing a single seed. Pollen monocolpate, semitectate and coarsely reticulate with broad scattered columellae.

Comments on the genus. Choffaticarpus is distinguished from Reyanthus (described below) by the tight packing of the fruiting units, the lack of oil cells and the much longer receptacle. Archaeanthus linnenbergeri Dilcher et P.R.Crane from the mid-Cretaceous Dakota Formation (Dilcher and Crane 1984) has a comparable elongated receptacle with many spirally arranged fruitlets, but is much larger, the fruitlets are loosely arranged along the receptacle, and each fruitlet contains many small seeds. This contrasts with the densely packed, one-seeded fruitlets of Choffaticarpus. Multicarpellate structures from other Early Cretaceous localities remain to be described but some may be related to the dispersed fruiting units of Anacostia E.M.FrIIs, P.R.CRANe et K.R.PEDERSEN described from Portugal and Virginia (Friis et al. 1997). These multicarpellate structures are comparable to Choffaticarpus in the strongly extended receptacle and the densely packed nature of the apparently one-seeded fruitlets, but these structures are conical rather than elliptical in shape and the individual fruitlets are not laterally flattened as in Choffaticarpus.

\section{Choffaticarpus compactus E.M.FrIIS, P.R.CRANE et K.R.Pedersen sp. nov. Text-fig. $49 \mathrm{~d}-\mathrm{j}$}

H o l o t y p e. Designated here. S136725 (Torres Vedras sample 43; figured Text-fig. 49d-j).

Plant Fossil Names Registry Number. PFN000490 (for new species).

P a r a ty p e. S137918 (Torres Vedras sample 44).

R e p o s i t o r y. Palaeobotanical Collections, Department of Palaeobiology, the Swedish Museum of Natural History, Stockholm, Sweden.

Et y m o log y. From Latin: compactus referring to the compact structure of the fruit.

Type locality. Torres Vedras (NE of Forte de Forca; 39 $06^{\prime} 13^{\prime \prime} \mathrm{N}, 9^{\circ} 14^{\prime} 47^{\prime \prime} \mathrm{W}$ ).

Type stratum and age. Lower member of the Almargem Formation; Early Cretaceous (late Barremianearly Aptian).

\section{D i a g n o s is. As for the genus.}

D i m e n s i o n s . Length of fruit: $4.2 \mathrm{~mm}$; width of fruit: $2.8 \mathrm{~mm}$

Description and remarks. Choffaticarpus compactus is based on a single multicarpellate and apocarpous fruit that has been illustrated previously, but without formal description (Reproductive structure with many carpels in Friis et al. 2010a). There is also a single isolated fruitlet. Additional specimens assigned to this species are known from the Catefica and Buarcos mesofossil floras.

The fruit from Torres Vedras, as well as isolated fruitlets from Catefica, were studied using SEM and SRXTM. The Torres Vedras specimen consists of many fruitlets arranged helically along a long, slender receptacle to form a compact structure (Text-fig. 49d, e). The fruitlets are strongly compressed laterally and the only exposed regions in the compound fruit are the diamond-shaped faces of the fruitlets. The stigmatic region is indistinct and occurs towards the base in an elongated depression in the diamond-shaped surface of the fruitlets (Text-fig. 49e). This is more distinct in a specimen of Choffaticarpus from the Buarcos locality (Friis et al. 2000a: fig. 3A, D). Stout, short trichomes are present along the borders of adjacent fruitlets and the stigmatic area (Text-fig. 49f). The lateral faces of the fruitlets are smooth. Each fruitlet contains a single seed (Text-fig. 49h-j). The cellular preservation as seen in SRXTM is good, but the fruits and seeds are crowded and have been compressed during fossilization making their structure and organization difficult to study. The micropyle points towards the central axis (Text-fig. 49i, j) and it is likely the seeds are anatropous. The seed coat is thin composed of narrow, longitudinally aligned cells (Text-fig. 49j).

The wall of each fruitlet consists of an inner layer of elongate sclerenchyma cells that line the locule. On the lateral faces of the fruitlets this layer of sclerenchyma cells is covered by a single layer of epidermal cells. The outer wall of the fruitlets is thicker and composed of thin-walled parenchyma cells covered by the epidermis (Text-fig. 49h).

Pollen attached to the surface of the fruitlets is circular in outline and about $11 \mu \mathrm{m}$ in diameter. Only the nonapertural face is exposed and the grains were most likely monocolpate. The exine is semitectate-reticulate with a homobrochate reticulum, rounded muri, and broad, scattered columellae. The surface of the foot layer is finely granular (Text-fig. 49g).

Affinity and other occurrences. The tightly packed fruitlets borne on a long central receptacle resemble the gynoecium and fruits of extant Kadsura KaEmPF. ex Juss. and Schisandra Michx. (Schisandraceae). However, the seeds of Choffaticarpus differ from those of Schisandraceae in their much thinner seed coat, and the systematic affinity of Choffaticarpus is currently uncertain. Fragments of a Choffaticarpus fruit and isolated fruitlets are also known from the Buarcos and Catefica localities.

\section{Genus Reyanthus E.M.FriIs, P.R.Crane et K.R.PEDERSEn gen. nov.}

Type. Designated here. Reyanthus lusitanicus E.M.Fris, P.R.Crane et K.R.Pedersen gen. et sp. nov. 

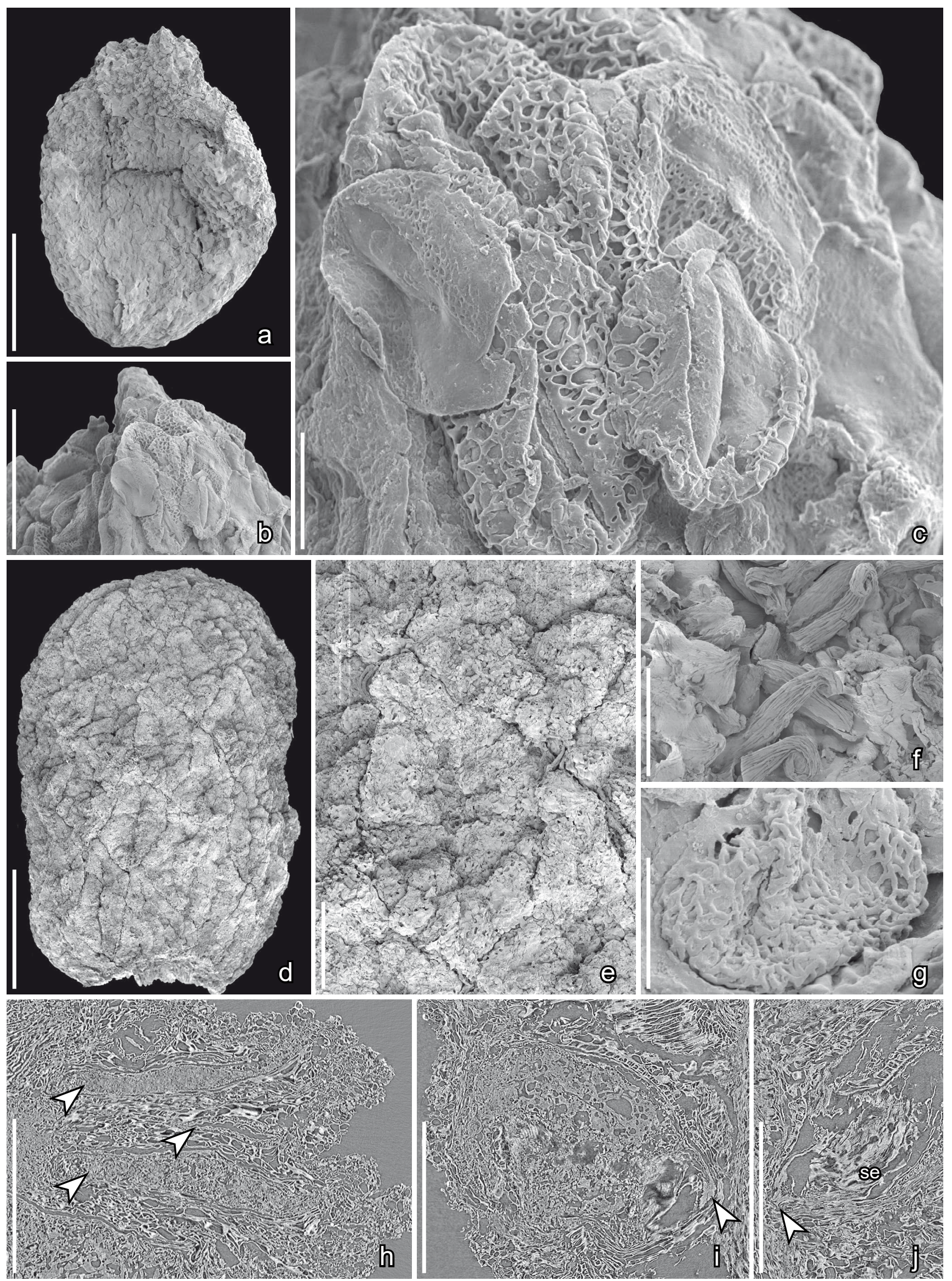

Text-fig. 49. Scanning electron microscope (SEM) and synchrotron radiation X-ray tomographic microscopy (SRXTM) images of Vedresia elliptica gen. et sp. nov. (a-c) and a multicarpellate fruit of Choffaticarpus compactus gen. et sp. nov. and associated pollen (d-j); Torres Vedras locality, Portugal. a) Holotype; small fruit showing apical stigmatic region with attached pollen; b) Group of pollen grains from the stigmatic surface of the fruit in (a) showing the long colpus and reticulate tectum; c) Pollen grains from the stigmatic surface showing the long colpus and well developed reticulum, with smooth muri and short columellae 
Plant Fossil Names Registry Number. PFN000491 (for new genus).

Ety m o logy. In honor of the French palaeontologist Jaques Rey in recognition of his contribution to the study of Early Cretaceous deposits in Portugal, including in the Torres Vedras region.

Diagnosis. Flower bisexual, multiparted, borne terminally on a long stalk. Tepals and stamens arranged in two series around the gynoecium. Gynoecium multicarpellate, apocarpous with carpels arranged helically on a conical receptacle. Carpel follicular containing several seeds borne along either side of the ventral suture. Stalk, bracts, tepals, stamens and carpels containing large, spherical oil cells. Carpels crescent-shaped, slightly compressed laterally. Stigma sessile, indistinct.

Comments on the genus. Several multicarpellate floral structures are known from Early and mid-Cretaceous strata. Most of these are currently undescribed, but one flower, Cecilanthus polymerus Herend., J.A.Doyle, P.K.ENDRESS et MAS.TAKAH., from the early Cenomanian of Maryland has comparable short conical receptacle and floral tissues with abundant oil cells (Herendeen et al. 2016). Cecilanthus polymerus differs from Reyanthus lusitanicus in the much greater number of floral parts and the arrangement of the tepals in multiple series. Reyanthus is distinguished from multicarpellate floral structures of Choffaticarpus (described above) by the more loosely packed fruiting units, the presence of oil cells and the much shorter receptacle.

\section{Reyanthus lusitanicus E.M.Fris, P.R.Crane et K.R.Pedersen sp. nov. Text-fig. 50a-j}

H o l o ty p e. Designated here. S136716 (Torres Vedras sample 299; figured Text-fig. 50a-f).

Plant Fossil Names Registry Number. PFN000492 (for new species).

P a r a t y p e. Designated here. S136717 (Torres Vedras sample 299).

Re p o s i t or y. Palaeobotanical Collections, Department of Palaeobiology, the Swedish Museum of Natural History, Stockholm, Sweden.

Etymology. From Latin: Lusitania for Portugal where the fossil was discovered.

Type locality. Torres Vedras (NE of Forte de

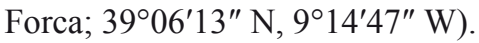

Type stratum and age. Lower member of the Almargem Formation; Early Cretaceous (late Barremianearly Aptian).

D i a gno s is. As for the genus.

D imensi ons. Length of flower without stalk: ca. $0.48 \mathrm{~mm}$; width of flower: ca. $0.58 \mathrm{~mm}$.

Description and remarks. Reyanthus lusitanicus is based on a single multiparted flower and a group of detached carpels, all of which have been studied with SEM and SRXTM. The flower is borne on a stout stalk that has an associated bract (Text-fig. 50a, b). Below the flower is another bract with a small bud in its axil, which is probably an undeveloped flower (Text-fig. 50b). The outer parts the flower are abraded and tepals and stamens are poorly preserved. The number and arrangement of tepals and stamens is uncertain. Small dorsiventrally flattened structures immediately outside the carpels are the probable remains of stamens, or perhaps staminodes (Text-fig. 50e). The tepals and stamens are each apparently arranged in a single series. The gynoecium is multicarpellate and apocarpous. It consists of about 20 carpels borne helically on a short conical receptacle (Text-fig. 50a-f). The carpels are crescent-shaped, slightly flattened laterally and have a straight ventral margin. The stigma is sessile, indistinct. The flower appears to be preserved at anthesis and the number of ovules is not clear. However, the detached carpels are larger and probably more mature (Text-fig. 50g-j). These detached carpels are assigned to Reyanthus lusitanicus based on their shape, and also the anatomy of the carpel wall. They contain several ovules borne along either side of the ventral suture. None of the fossil material is sufficiently well preserved to provide information on the organization of the ovules. All floral parts contain large, spherical cells that are densely spaced throughout the tissues, which we interpret as oil cells. In the larger, isolated carpels the oil cells are embedded in the outer tissue of the carpel wall (Text-fig. 50i, j) and are often visible on the carpel surface or sometimes as holes in the fruit wall (Text-fig. 50g, h).

Affinity and other occurrences.Reyanthus lusitanicus is known only from the Torres Vedras locality. Taken together, the multiparted organization, the presence of oil cells and the several ovules per carpel indicate affinity with Magnoliales, but there is no clear relationship to a specific extant taxon.

\section{Eudicot angiosperms}

R e m a r k s. Remains that can be assigned with certainty to eudicot angiosperms are rare and include only three specimens with tricolpate pollen. Three stamens that were briefly described and illustrated previously, one of which has

that are only loosely attached to the smooth surface of the foot layer; d-e) Holotype; multicarpellate fruit showing helical arrangement (d) and detail (e) of carpels surrounded by hairs (f); note that the scale bar (1.2 mm rather than $300 \mu \mathrm{m})$ is four times larger that used for most other mesofossils illustrated in this paper; g) Monocolpate pollen with reticulate pollen wall from the surface of the flower in (d); h) Transverse section (orthoslice xy3960) showing three seeds (arrowhead) enclosed by carpel tissue; i) Longitudinal section (orthoslice yz1155) showing section through seed with micropyle (arrowhead); j) Longitudinal section (orthoslice yz1183) showing seed with micropyle (arrowhead) and narrow elongate cells of thin seed coat (se). Specimens, TV43-S136735 (holotype; a-c), TV43-S136725 (holotype; d-j). Scale bars $1.2 \mathrm{~mm}$ (d), $500 \mu \mathrm{m}$ (h-j), $300 \mu \mathrm{m}(\mathrm{a}, \mathrm{e}), 60 \mu \mathrm{m}$ (f), $30 \mu \mathrm{m}(\mathrm{b}), 6 \mu \mathrm{m}(\mathrm{c}, \mathrm{g})$. 

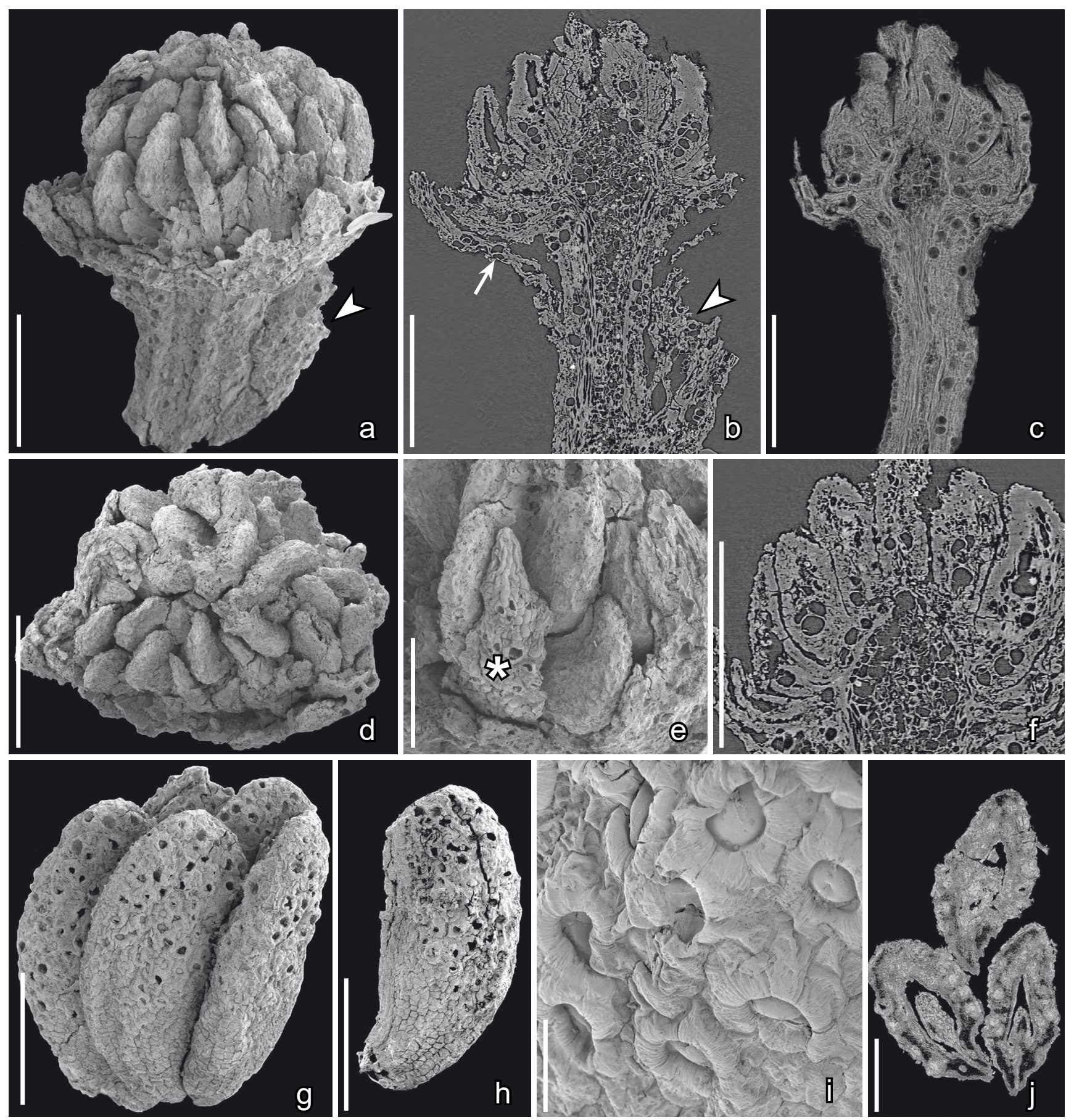

Text-fig. 50. Scanning electron microscope (SEM) and synchrotron radiation X-ray tomographic microscopy (SRXTM) images of a flower and mature carpels of Reyanthus lusitanicus gen. et sp. nov.; Torres Vedras locality, Portugal. a) Holotype; multicarpellate flower showing numerous carpels surrounded by remains of the androecium and perianth; note the bract subtending the flower (arrowhead); b, c) Longitudinal sections perpendicular to section in (f) (b, SRXTM orthoslice xz0461) and (c, SRXTM cut voltex xz0540-0580) showing receptacle, carpels and remains of the androecium and perianth; note prominent cavities formed by the oil cells, subtending bract (arrow) and bract subtending fragmentary bud (arrowhead); d, e) Apical (d) and lateral (e) views of gynoecium showing laterally flattened carpels and dorsi-ventrally flattened stamen or staminode (* in e); f) Longitudinal section (SRXTM orthoslice yz0405) of gynoecium showing conical receptacle and carpels with densely spaced oil cells; g, h) Mature carpel of Reyanthus lusitanicus gen. et sp. nov. showing slightly curved form, rounded apex and base that tapers toward the attachment to the receptacle; i) Surface of carpel showing embedded oil cells; j) Transverse section through three carpels showing attachment of developing ovules near the ventral sutures and oil cells in the wall just below the surface (SRXTM cut voltex xy0770-0845). Specimens TV299-S136716 (holotype; a-f), TV299-S136717 (g-j). Scale bars $300 \mu \mathrm{m}$ (a-d, f-h), $150 \mu \mathrm{m}(\mathrm{e}, \mathrm{j}), 30 \mu \mathrm{m}$ (i).

distinct tricolpate pollen (stamen with foveolate, tricolpate pollen; Friis et al. 1994b: fig. 9e-f), are from the Puddledock flora, Virginia, USA (Puddledock sample 149), and not from the Torres Vedras flora as previously reported.
Genus Mcdougallia E.M.Fris, P.R.Crane et K.R.Pedersen gen. nov.

Type. Designated here. Mcdougallia irregularis E.M.Fris, P.R.Crane et K.R.PEdERSEN gen. et sp. nov. 
Plant Fossil Names Registry Number. PFN000493 (for new genus).

Etymology. In honor of the British palynologist Audrey B. McDougall in recognition of her contribution to the study of Early Cretaceous angiosperms.

D i a g n o s i s . Pollen, small, almost spherical, tricolpate. Colpi long, reaching almost to the poles sometimes separated by irregular folds. Exine tectate-punctate in the polar regions and along the colpi; tectate-foveolate to reticulate in mesocolpial regions. Columellae short. Colpus margin distinct. Colpus membrane verrucate. Orbicules small, spherical with faintly striate surface.

Comments on the genus. The short, irregular folds that occur between the regular colpi in Mcdougallia seem to indicate irregular development of the three colpi. Similar irregular folds also occur in the basically tricolpate pollen grains of Samylinaea punctatus (see below) but these grains are larger, and have a homogenous tectum and coarsely verrucate colpus membrane. Grains assigned to the informal biorecord Punctitri-Fineret from the mid-Aptian to midAlbian of Egypt (Penny 1991) appear to have similar irregular fold/openings between the regular colpi. These grains are smaller than those of Mcdougallia and the perforations in the tectum are larger. Irregular development of the colpi in taxa with predominantly tricolpate pollen has been described from the eudicot genus Nelumbo AdANS. (Kreunen and Osborn 1999), but grains of Nelumbo are distinct from those of Mcdougallia in the irregular vermiculate reticulum and tall columellae. Occasional irregular development of the colpi in tricolpate grains occurs in many eudicots (Banks et al. 2007), but the frequency of irregular grains among the Torres Vedras tricolpates seems unusually high.

\section{Mcdougallia irregularis E.M.FrIIS, P.R.CRANE et K.R.Pedersen sp. nov. Text-fig. 51a-f}

H o 1 o t y p e. Designated here. S148215 (Torres Vedras sample 43; figured Text-fig. 51a-f).

Plant Fossil Names Registry Number. PFN000494 (for new species).

R e p o s i t o ry. Palaeobotanical Collections, Department of Palaeobiology, the Swedish Museum of Natural History, Stockholm, Sweden.

E t y m o log y. From Latin: irregularis referring to the irregular folds and colpi.

Type locality. Torres Vedras (NE of Forte de Forca; 39 $06^{\prime} 13^{\prime \prime} \mathrm{N}, 9^{\circ} 14^{\prime} 47^{\prime \prime} \mathrm{W}$ ).

Type stratum and age. Lower member of the Almargem Formation; Early Cretaceous (late Barremianearly Aptian).

D i a g n o s is. As for the genus.

D i m e n s i o n s. Equatorial diameter of pollen grains: about $19-20 \mu \mathrm{m}$.

Description and remarks. Mcdougallia irregularis is based on a fragment of a stamen, about
$0.48 \mathrm{~mm}$ long and $0.135 \mathrm{~mm}$ wide (Text-fig. 51a). Pollen grains in situ are small, almost spherical, about $19-20 \mu \mathrm{m}$ in diameter and tricolpate (Text-fig. 51b-d). The colpi are long, reaching almost to the poles and have a distinct margin (Text-fig. 51b-d). Shorter folds that appear as openings in the tectum are irregularly spaced between the regular colpi on all grains. The tectum is punctate in the polar regions and along the colpi. In the mesocolpial regions the tectum is foveolate to irregularly reticulate, and sometimes discontinuous (Text-fig. 51c). Columellae are very short (Text-fig. 51f). The colpus membrane is finely verrucate (Text-fig. 51c, d). Orbicules are densely spaced on the inner surface of the anther wall and scattered on the surface of the pollen. They are small and spherical with a faintly striate surface (Text-fig. 51e).

Affinity and other occurrences. Mcdougallia irregularis is known only from the Torres Vedras locality. The triaperturate pollen grains clearly indicate a relationship to eudicots, but specific relationships to extant taxa within the group are uncertain.

\section{Genus Samylinaea E.M.FriIs, P.R.Crane et K.R.Pedersen gen. nov.}

Ty p e . Designated here. Samylinaea punctata E.M.FrIIS, P.R.Crane et K.R.Pedersen gen. et sp. nov.

Plant Fossil Names Registry Number. PFN000495 (for new genus).

Ety m o logy. In honor of the Russian palaeobotanist Valentina A. Samylina in recognition of her contribution to the study of Cretaceous angiosperms.

Diagnosis. Pollen of medium size, prolate, tricolpate. Colpi long, reaching almost to the poles, irregular in organization, sometimes branched. Exine columellate, tectate-punctate. Columellae short. Colpus margin distinct. Colpus membrane coarsely verrucate. Orbicules small, spherical, with a finely granular surface.

Comments on the genus. Samylinaea is characterized by the presence of irregular folds or openings between the regular colpi, which sometimes create a branched appearance. Such irregularity is not common among eudicot angiosperms, but also occurs in the pollen of Mcdougallia described above.

\section{Samylinaea punctata E.M.Fris, P.R.Crane et K.R.Pedersen sp. nov. \\ Text-fig. 52a-h}

H o l o t y p e. Designated here. S174565 (Torres Vedras sample 44; figured Text-fig. 52a-h).

Plant Fossil Names Registry Number. PFN000496 (for new species).

R e p o s i t ory. Palaeobotanical Collections, Department of Palaeobiology, the Swedish Museum of Natural History, Stockholm, Sweden.

E t y m o log y. From Latin: punctatus referring to fine perforations of the tectum. 

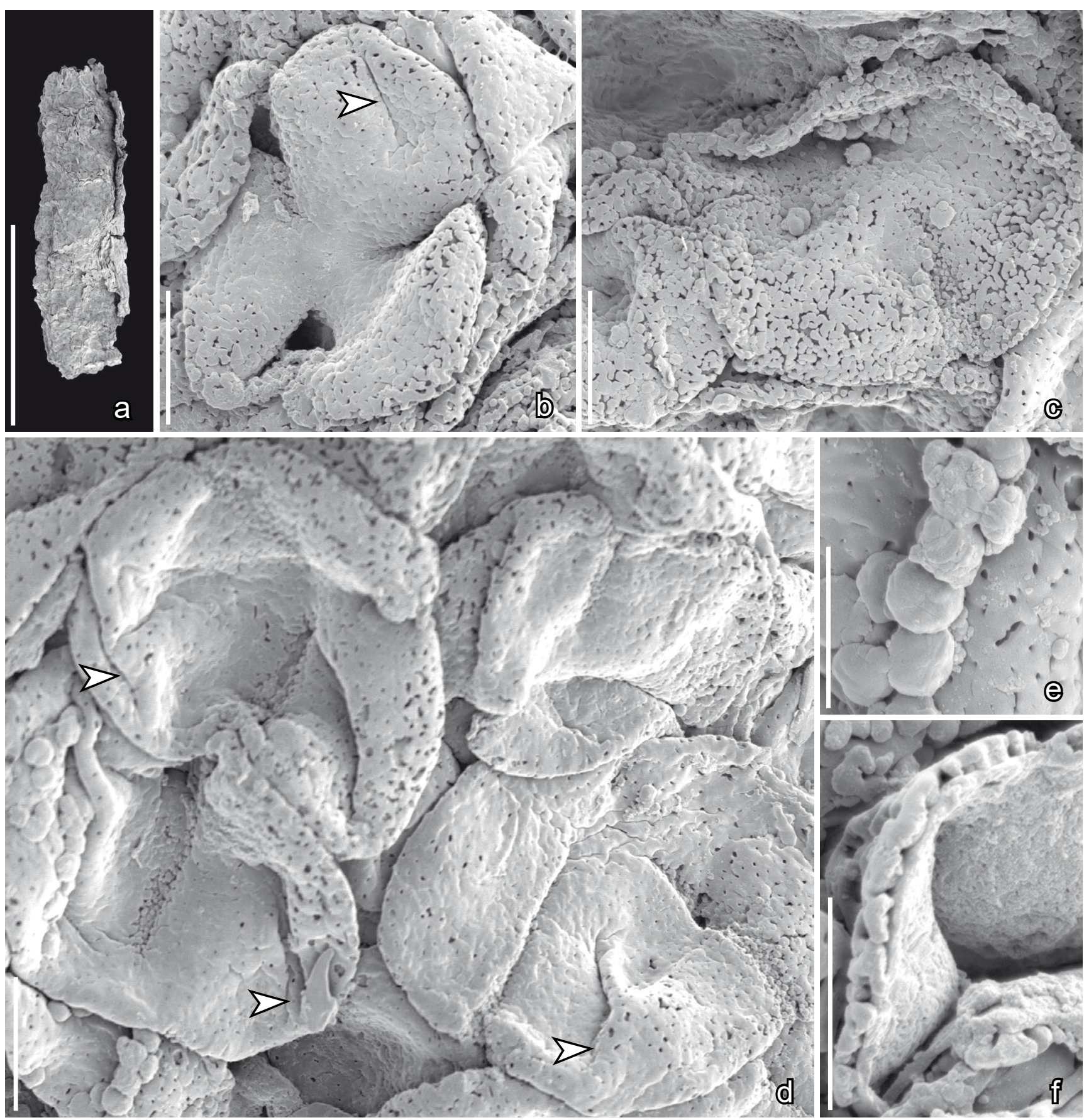

Text-fig. 51. Scanning electron microscope (SEM) images of tricolpate pollen of Mcdougallia irregularis gen. et sp. nov. from a stamen fragment; Torres Vedras locality, Portugal. a) Holotype; stamen fragment that yielded the pollen in this Text-figure; b) Polar view of tricolpate pollen grain showing the continuous psilate tectum in the apocolpium and the poorly developed discontinuous foveolate-reticulate tectum in the mesocolpial areas, note irregular fold in tectum wall (arrowhead); c) Equatorial view of pollen grain showing the discontinuous tectum in the mesocolpial areas; d) Pollen grains showing variably developed tectum, colpi with a finely granular aperture membrane and the folds (arrowheads) associated with the irregular development of the colpi; e) Orbicule showing faintly striate surface; f) Pollen wall showing very short columellae, thin tectum and thin foot layer. Specimen, TV44-S148215 (holotype). Scale bars $300 \mu \mathrm{m}$ (a), $6 \mu \mathrm{m}$ (b-d), $3 \mu \mathrm{m}$ (e, f).

Type locality. Torres Vedras (NE of Forte de

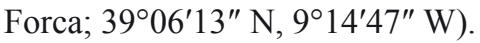

Type stratum and age. Lower member of the Almargem Formation; Early Cretaceous (late Barremianearly Aptian).

Diagnos is. As for the genus.

D i m e n s i o n s. Length of pollen grains: about $29 \mu \mathrm{m}$; width of pollen grains: about $21 \mu \mathrm{m}$.
Des cription and remarks. Samylinaea punctata is based on a single pollen clump comprising only one kind of pollen. It is probably a fragment of a stamen (Text-fig. 52a). The pollen is of medium size, prolate, with polar axis about $29 \mu \mathrm{m}$ long and about $21 \mu \mathrm{m}$ wide at the equator (Text-fig. $52 \mathrm{~b}, \mathrm{e}, \mathrm{g})$. The basic arrangement of the apertures is tricolpate, but their arrangement exhibits unusual variation. The colpi are long, reaching almost to the poles (Text-fig. 52b, g) and are often irregular and appear branched (Text-fig. 52e, f, h). 

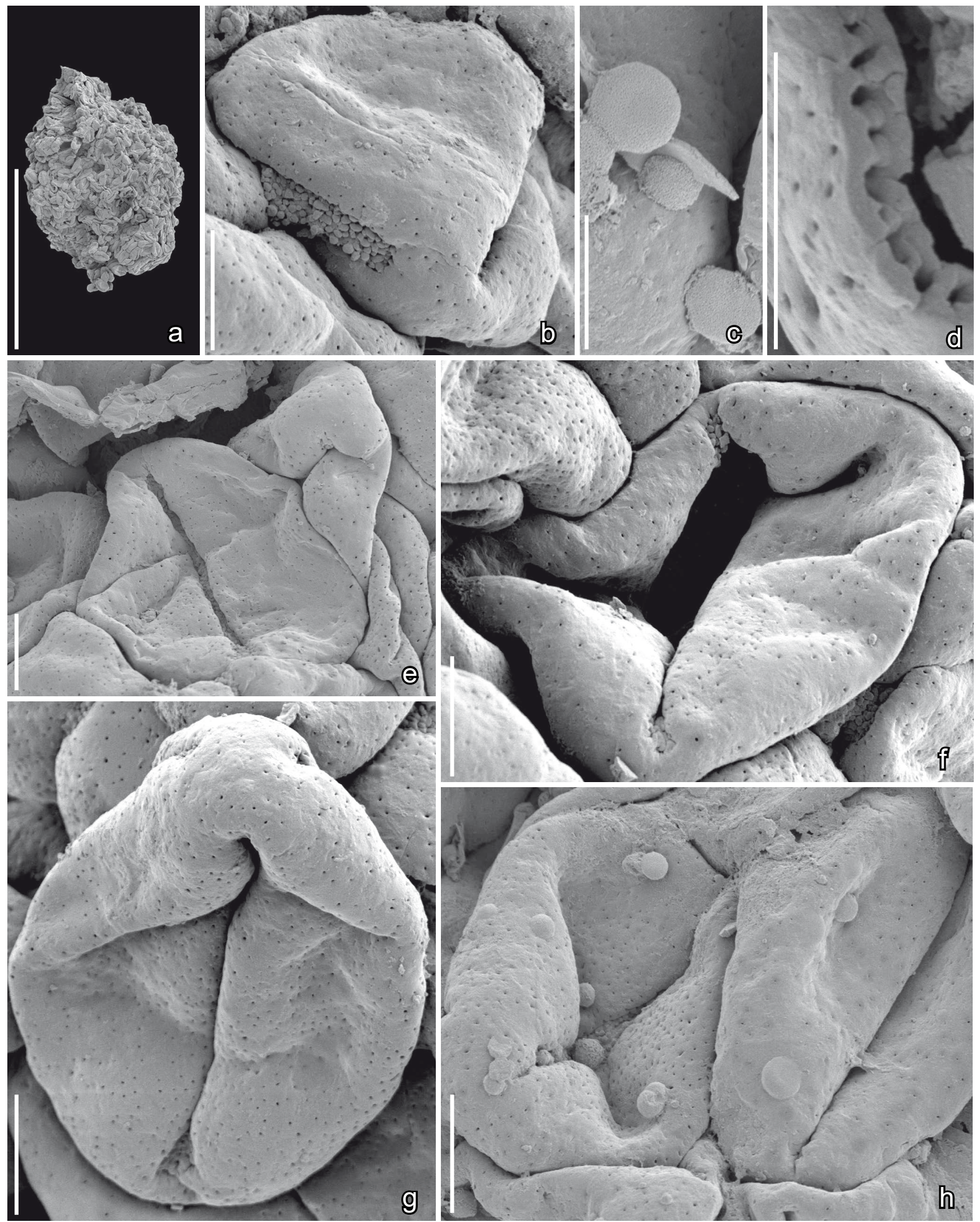

Text-fig. 52. Scanning electron microscope (SEM) images of tricolpate pollen of Samylinaea punctata gen. et sp. nov from a pollen clump; Torres Vedras locality, Portugal. a) Pollen clump (probable stamen fragment) that yielded the pollen in this Text-figure; b) Polar view of pollen grain showing two colpi, granular aperture membrane, and punctate tectum; c) Orbicule showing very finely granular surface; d) Pollen wall showing short columellae, well-developed punctate tectum and slightly thinner foot layer; e-h) Pollen grains showing punctate tectum and the folds associated with the irregular development of the colpi. Specimen, TV44-S174565 (holotype; a-h). Scale bars $300 \mu \mathrm{m}$ (a), $6 \mu \mathrm{m}$ (b, e-h), $3 \mu \mathrm{m}$ (c, d). 
The exine is tectate-punctate, and columellate with short columellae (Text-fig. 52d). The tectum and the infratectal columellate layer are of almost equal thickness, each about $0.3-0.4 \mu \mathrm{m}$ thick, while the foot layer is slightly thinner. The colpus margin is distinct and the colpus membrane coarsely verrucate (Text-fig. 52b, e, g, h). Small, spherical orbicules with a finely granular surface occur abundantly on the surface of the pollen grains (Text-fig. 52c, h).

Affinity and other occurrences. Currently Samylinaea punctata is known only from the Torres Vedras site. The triaperturate pollen grains clearly indicate a relationship to eudicots. Pollen of Samylinaea punctata shows some similarity with pollen found in situ in the ranunculalean flower Teixeiraea lusitanica BALTHAZAR, K.R.Pedersen et E.M.Fris from the Vale de Água locality (von Balthazar et al. 2005), but the pollen grains in Teixeiraea lusitanica flowers are smaller, lack the irregular folds, and have larger perforations in the tectum and orbicules that are smaller with a central depression. Tricolpate pollen with tectate-perforate pollen wall and very long colpi resembling the pollen of Samylinaea punctata was described from the mid-Aptian-mid-Albian of Egypt as Punctitri-Fineret (Penny 1991), but this pollen type is distinguished by its smaller size and larger perforations (foveolate-microreticulate).

\section{Genus Nicholsia E.M.Fris, P.R.Crane et K.R.Pedersen gen. nov.}

Type. Designated here. Nicholsia brevicolpites E.M.Fris, P.R.Crane et K.R.Pedersen gen. et sp. nov.

Plant Fossil Names Registry Number. PFN000497 (for new genus).

Ety mology. In honor of the American palynologist Douglas J. Nichols in recognition of his important contributions to the study of Cretaceous angiosperms.

D i a g n o s is. Pollen small, prolate, tricolpate. Colpi short. Tectum foveolate to microreticulate. Perforations rounded and of even size over the main body of the grains. Colpus margin indistinct. Colpus membrane verrucate.

Comments on the genus. Pollen grains of Nicholsia are distinguished from that of Mcdougallia in the even size and distribution of the perforations in the tectum and the shorter colpi. Pollen grains of Nicholsia are distinguished from pollen of Samylinaea in the larger size of the perforations and shorter colpi.

\section{Nicholsia brevicolpites E.M.FrIIS, P.R.CRANE et K.R.Pedersen sp. nov. Text-fig. 53a-d}

Holotype. Designated here. S137906-03 (Torres Vedras sample 44; figured Text-fig. 53a-d).

Plant Fossil Names Registry Number. PFN000498 (for new species).

Rep o s it ory. Palaeobotanical Collections, Department of Palaeobiology, the Swedish Museum of Natural History, Stockholm, Sweden.
E t y m o log y. From Latin: brevis and colpus referring to the short colpi.

Type locality. Torres Vedras (NE of Forte de Forca; 3906'13" N, 9¹4'47" W).

Type stratum and age. Lower member of the Almargem Formation; Early Cretaceous (late Barremianearly Aptian).

D i a g n o s is. As for the genus.

Dimensions. Length of pollen grains: about 24$25 \mu \mathrm{m}$; equatorial diameter of pollen grains: about $22 \mu \mathrm{m}$.

Description and remarks. Nicholsia brevicolpites is based on grains that occur in a coprolite together with several other kinds of pollen (Text-fig. 53a). The pollen grains are small, prolate, with an almost circular equatorial outline, and tricolpate with short colpi (Text-fig. $53 \mathrm{~b}-\mathrm{d})$. The tectum is foveolate to microreticulate with small rounded perforations that are of even size over the main body of the grains (Text-fig. 53b-d). The colpi have indistinct margins and a verrucate colpus membrane (Text-fig. 53b, d).

Affinity and other occurrences. Nicholsia brevicolpites is known only from the Torres Vedras site. The triaperturate pollen grains clearly indicate a relationship to eudicots, but specific relationships to extant taxa within the group are uncertain.

Dispersed pollen with a similar foveolate to microreticulate tectum is reported from the mid-Aptianmid-Albian of Egypt as Punctitri-Fineret (Penny 1991), but the Egyptian pollen is smaller and has longer colpi.

\section{Angiosperms of uncertain affinity}

R e marks. Under this heading, we describe several different kinds of angiosperm fossil from the Torres Vedras locality that cannot be placed with certainty in any of the major extant lineages of angiosperms. All are represented by just one, or a few, specimens. They are included here without formal naming in order to provide full documentation of the diversity of plants in the Torres Vedras mesofossil flora.

\section{Angiosperm follicle sp. 1 Text-fig. $54 \mathrm{a}$}

Description and remarks. The species is represented in the Torres Vedras mesofossil flora by a single isolated follicle, about $1.8 \mathrm{~mm}$ long and $0.4 \mathrm{~mm}$ wide (Textfig. 54a). The follicle has a broad attachment scar at the base. The apex is rounded with a short decurrent stigma. No pollen grains have been observed associated with the follicle. The fruit wall is thick and woody with an almost smooth surface and a broad, shallow groove extending from base to apex. The epidermal cells of the fruit wall have polygonal and equiaxial facets. The specimen has not been studied using SRXTM and the number of ovules/seeds is unknown.

Affinity and other occurrences. Several different kinds of isolated follicles occur in the Early Cretaceous mesofossil floras of Portugal. Some are known to be derived from multicarpellate gynoecia, others are always found isolated and it is unknown whether they are 

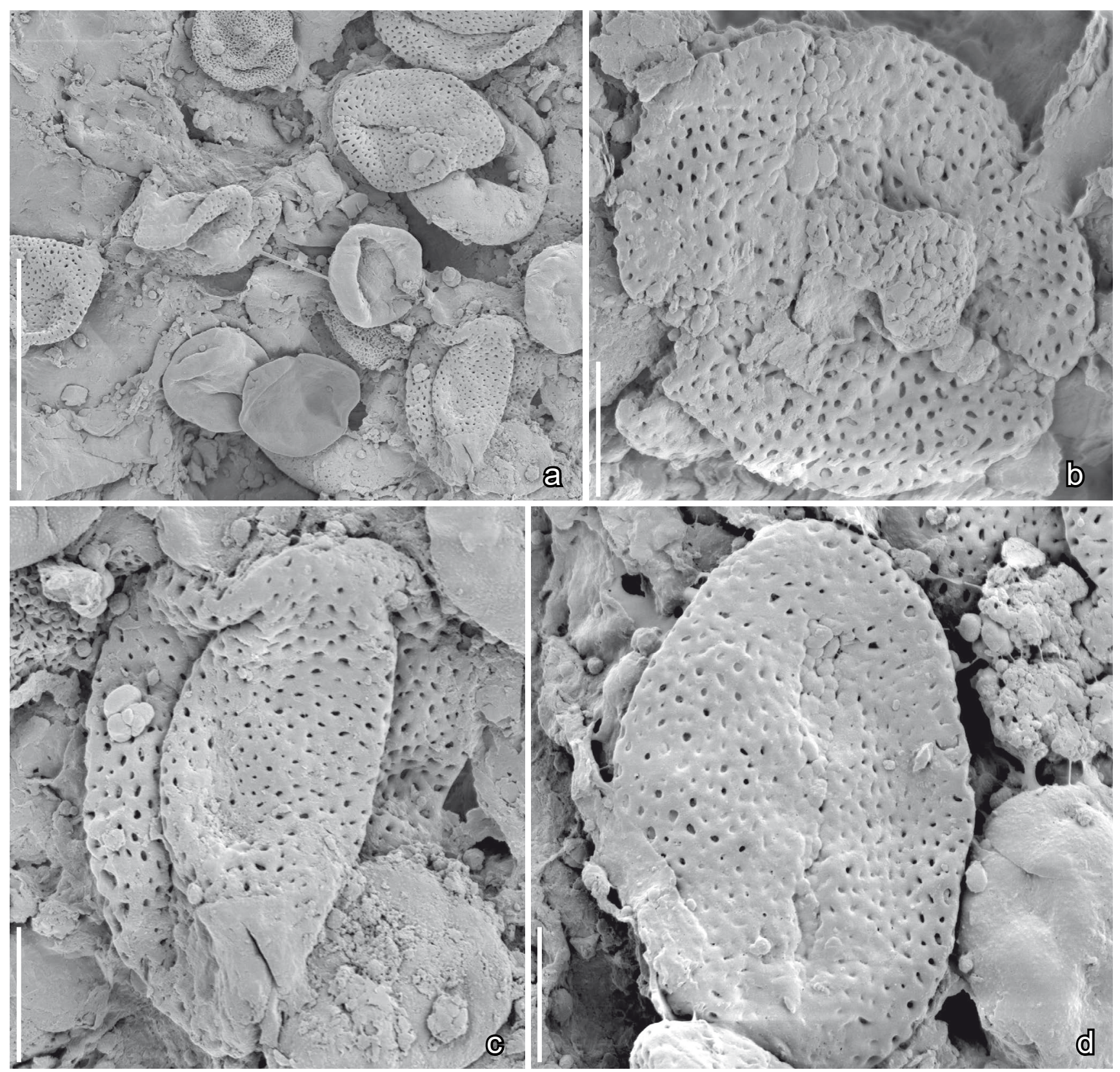

Text-fig. 53. Scanning electron microscope (SEM) images of tricolpate pollen of Nicholsia brevicolpites gen. et sp. nov. from a coprolite containing several kinds of pollen; Torres Vedras locality, Portugal. a) Detail of the coprolite that yielded the tricolpate pollen in this Text-figure showing several different kinds of pollen grains; b-d) Tricolpate pollen grains in polar (b) and equatorial (c, d) views showing colpi, coarsely granular aperture membrane and foveolate tectum. Specimen, TV44-S137906-03 (holotype; a-d). Scale bars $30 \mu \mathrm{m}(\mathrm{a}), 6 \mu \mathrm{m}$ (b-d).

from gynoecia that were unicarpellate or multicarpellate. The follicles figured here differ from those of Reyanthus lusitanicus (see above) in their larger size and in the lack of ethereal oil cells in the follicle wall.

\section{Angiosperm follicle sp. 2}

\section{Text-fig. 54b}

Description and remarks. The species is represented in the Torres Vedras mesofossil flora by a single isolated follicle, about $1.2 \mathrm{~mm}$ long that has dehisced along the ventral suture (Text-fig. 54b). Several scars along the internal surface of the ventral suture indicate that the carpel originally enclosed several seeds. The follicle wall is thick and woody with the locule lined by long and narrow, transversely oriented sclerenchyma cells. The stigmatic area is sessile and indistinct. No pollen grains were observed on the stigmatic surface.

Affinity and other occurrences. Follicles of similar general form occur in several families of extant angiosperms that are widely separated systematically. The lack of distinctive features, for example of ovule/ seed organization or associated pollen, precludes secure systematic placement of these fossils. Among the Portuguese mesofossil floras follicles similar to "Follicle sp. 2" are also known from the Catefica and Vale de Água mesofossil floras. 


\section{Wedge-shaped angiosperm fruit \\ Text-fig. $54 \mathrm{i}$}

Description and remarks. The material comprises two wedged-shaped fruits, about $1.4 \mathrm{~mm}$ long and $0.7 \mathrm{~mm}$ broad with remains of tepals close to the apex. One fruit (S174685) was studied using SRXTM. It is unilocular and contains a single, pendulous, anatropous seed with a tiny embryo.

Affinity and other occurrences. This kind of wedge-shaped fruit is common in other Early Cretaceous mesofossils floras from Portugal (Arazede, Catefica, Famalicão). The Torres Vedras specimen is well-preserved and well-preserved specimens are known from other localities, but the systematic relationships of these fossils are currently unresolved.

\section{Angiosperm seeds, sp. 1 - sp. 5 Text-fig. $54 \mathrm{c}-\mathrm{h}$}

De s c ription and remarks. Five different kinds of small seeds, all represented by only one or two specimens, are described here to provide as complete documentation of the Torres Vedras mesofossil flora as possible.

Angiosperm seed sp. 1 (Text-fig. 54c) is small, thinwalled, about $0.45 \mathrm{~mm}$ long and $0.26 \mathrm{~mm}$ broad, with a smooth surface. The seed is apparently hemiorthotropous, with a pointed micropyle and a distinct, round scar at the chalazal end.

Angiosperm seed sp. 2 (Text-fig. 54d) is a small anatropous seed, about $0.55 \mathrm{~mm}$ long and $0.45 \mathrm{~mm}$ broad, bilaterally symmetrical with a distinct raphe and rounded hilar scar next to the micropyle. The seed surface is characterized by small verrucae arranged in longitudinal rows.

Angiosperm seed sp. 3 (Text-fig. 54e) comprises two small foveolate seeds about $0.6-0.7 \mathrm{~mm}$ long and $0.6 \mathrm{~mm}$ broad. They have a thick exotesta of palisade-shaped cells with folded anticlinal walls.

Angiosperm seed sp. 4 (Text-fig. 54f) is a small seed (or possibly a one-seeded fruit) about $0.7 \mathrm{~mm}$ long and $0.45 \mathrm{~mm}$ broad (Text-fig. 54f). The epidermal cells are large with polygonal and equiaxial facets. The specimen was studied using SRXTM, which revealed a small tiny embryo, but the tissues surrounding the nucellus are more or less homogenized and difficult to interpret.

Angiosperm seed sp. 5 (Text-fig. 54g, h) is known from two small seeds about $0.55-0.59 \mathrm{~mm}$ long and $0.22-$ $0.31 \mathrm{~mm}$ broad. The seeds have a reticulate surface formed by the slightly raised facets of the epidermal cells.

Affinity and other occurrences.Angiosperm seed sp. 1 is similar in gross morphology to seeds of Appomattoxia ancistrophora from Virginia, USA, and is also in the size range of fruits of Appomattoxia minuta (see p. 190 herein). It could possibly be a seed detached from an Appomattoxia fruit.

Seeds similar to Angiosperm seed sp. 2 and sp. 4 have not been recovered in other Early Cretaceous mesofossil floras from Portugal, and the systematic relationships of these species are unknown.

Angiosperm seed sp. 3 is rare in the Torres Vedras mesofossil flora but very common in certain other mesofossil floras from Portugal (Arazede, Buarcos, Catefica). More detailed investigations of this species will be possible in the future based on a broader examination of seeds from several localities and more detailed analyses of anatomical features.

Seeds similar to angiosperm seed sp. 5 also occur in the Catefica flora, but the Catefica seeds are larger and may belong to another species.

\section{Genus Ibrahimia E.M.Fris, P.R.Crane et K.R.Pedersen gen. nov.}

Type. Designated here. Ibrahimia vermiculata E.M.Fris, P.R.Crane et K.R.Pedersen gen. et sp. nov.

Plant Fossil Names Registry Number. PFN000499 (for new genus).

Ety m o logy. In honor of the Egyptian palynologist Mohamed I. A. Ibrahim in recognition of his important contributions to Cretaceous palynology.

Diagnosis. Pollen minute, spheroidal and pantoporate with simple apertures. Exine tectate-vermiculate with widely spaced stout conical microechinae. Aperture membranes granular to verrucate. Orbicules not observed.

Comments on the genus. Pantoporate pollen with spiny supratectal ornamentation also occurs in situ in the flowers of Paisia pantoporata described from the Catefica mesofossil flora (Friis et al. 2018e). Pollen grains of $P$. pantoporata are similar to those of Ibrahimia in having supratectal elements that are apparently composed of intertwining exine elements. However, in P. pantoporata the echinae have constricted bases and form a dense ring around each aperture. This distinctive arrangement differs from that seen in the pollen grains of Ibrahimia. Pantoporate pollen grains are relatively common in dispersed palynological assemblages from the Early Cretaceous (Ibrahim et al. 2015), but none of them have exine sculpture comparable to that seen in the grains of Ibrahimia or P. pantoporata (see discussion in Friis et al. 2018e).

\section{Ibrahimia vermiculata E.M.FRIIS, P.R.CRANE et K.R.Pedersen sp. nov. Text-fig. 55a-h.}

H o l o t y p e. Designated here. S148019 (Torres Vedras sample 44; figured Text-fig. 55a-f).

Plant Fossil Names Registry Number. PFN000500 (for new species).

P a r a ty pes. Designated here. S136766-01, S136782 (Torres Vedras sample 44).

Re p o s i t o ry. Palaeobotanical Collections, Department of Palaeobiology, the Swedish Museum of Natural History, Stockholm, Sweden.

Ety mology. From Latin: vermiculatus referring to the worm-shaped, winding sculptural elements.

Type locality. Torres Vedras (NE of Forte de Forca; 3906'13" N, 9¹4'47" W).

Type stratum and age. Lower member of the Almargem Formation; Early Cretaceous (late Barremianearly Aptian). 


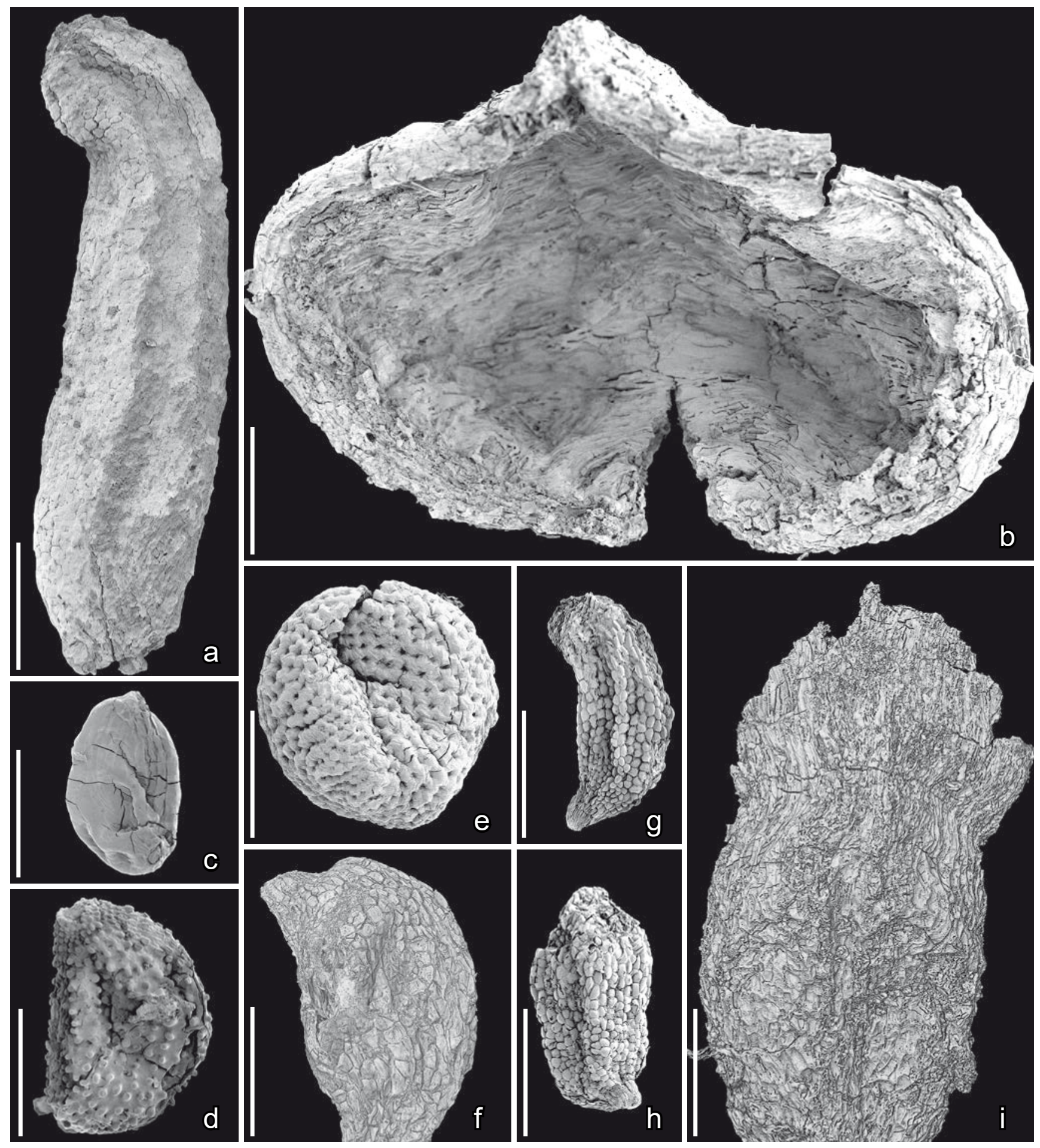

Text-fig. 54. Scanning electron microscope (SEM; a-e, g, h) and synchrotron x-ray microscopy (SRXTM; f, i) images of unnamed angiosperm fruits and seeds; Torres Vedras locality, Portugal. a) Follicle sp. 1, narrow elongate follicle with sessile and decurrent stigma; b) Follicle sp. 2, broad, dehisced follicle with elongate and transverse fibers lining the locule; c) Angiosperm seed sp. 1 with thin, smooth seed coat; d) Angiosperm seed sp. 2 with verrucate seed coat; e) Angiosperm seed sp. 3 with exotestal and foveolate seed coat; f) Angiosperm seed sp. 4 with smooth seed coat; g, h) Angiosperm seed sp. 5 with raised epidermal cells forming a reticulate pattern; i) Wedge-shaped angiosperm fruit with remains of floral parts near apex. Specimens, TV43-S136726 (a), TV44-S148144 (b), TV43-S170074 (c), TV43-S136747 (d), TV43-S170073 (e), TV38-S174615 (f), TV44-S148003 (g), TV44-S148004 (h), TV43-S174685 (i). Scale bars $300 \mu \mathrm{m}(\mathrm{a}-\mathrm{i})$.

\section{D i a g n o s is. As for the genus.}

D i m e n s i o n s. Diameter of pollen grains: 15-17 $\mu \mathrm{m}$.

Description and remarks. Pollen grains of Ibrahimia vermiculata have been found in situ in two fragmentary anthers (Text-fig. 55a, g) and also in a coprolite that contains mainly Goczania type pollen grains. One of the anthers and its enclosed pollen (Text-fig. 55g, h) appears degraded, but the pollen grains are similar in size and sculpturing to those in the other anther and in the coprolite. The pollen grains are spheroidal, minute, and about $15-17 \mu \mathrm{m}$ in diameter. They are pantoporate with 
about six circular pores. The exine is tectate-vermiculate with a supratectal ornamentation of conical microechinae up to about $0.9 \mu \mathrm{m}$ long (Text-fig. 55b-f, h). The microechinae are not constricted at the base and have a blunt tip. The vermiculate sculpturing of the main pollen body continues into the base of the microechinae (Text-fig. 55f). The aperture membrane is finely granular to verrucate (Text-fig. $55 \mathrm{e}, \mathrm{f})$. Orbicules were not observed.

Affinity and other occurrences. Ibrahimia vermiculata has so far only been recorded from the Torres Vedras mesofossil floras. However, other kinds of pantoporate pollen are known from other Portuguese mesofossil floras. Pantoporate reticulate pollen grains of possible chloranthoid affinity are known from Famalicão (Friis et al. 1999) and pantoporate reticulate pollen grains of possible araceous affinity are known from the Vila Verde 2 locality (Friis et al. 2010b). Microechinate and pantoporate pollen grains have also been found in situ in flowers of Paisia pantoporata from the Catefica locality that are probably of ranunculalean affinity (Friis et al. 2018e). The Ibrahimia grains are closely similar to those from the Paisia flowers, and they may also be systematically closely related. However, the Paisia grains are smaller, lack the vermiculate tectal sculpturing and the spines are constricted at their bases.

\section{Pantoporate-reticulate-foveolate pollen Text-fig. $55 \mathrm{i}$}

Description and remarks. The species is based on a small fragment, perhaps from a stamen, with a few adhering pantoporate pollen grains. The grains are spherical, about $17 \mu \mathrm{m}$ in diameter, with up to about 10 small, equally distributed rounded pores. The tectum is microreticulate to foveolate. The pores are well delimited with a verrucate aperture membrane (Text-fig. 55i).

Affinity and other occurrences. Similar pollen grains have not been observed in other Early Cretaceous mesofossil floras from Portugal. They are distinguished from pollen of Paisia and Ibrahimia by the absence of echinae, and from polyporate pollen from Famalicão by the microreticulate-foveolate tectum. Several different kinds of non-echinate pantoporate pollen are known from dispersed palynofloras and have been assigned to the extinct genus Cretacaeiporites HeRngreEn (e.g. Ibrahim et al. 2015). It is possible that the Portuguese grains belong to one of the existing species, although comparison with LM images have not provided a close match.

\section{Composition of the mesofossil flora}

The mesofossil flora reported here was extracted from 11 samples collected very close to each other within the same organic rich horizon in the lower part of the Almargem Formation at the Torres Vedras locality. Mesofossils such as megaspores, sporangia, twigs and tiny leaves, seed, fruits, stamens and flowers are very rare in the samples and are estimated to constitute less than $0.01 \%$ of the organic fragments that we have sorted (see Material and methods). About 2,000 plant fragments were separated and investigated from the organic residue of the two largest samples (TV43 and TV44) and about 1,700 of these were identified. Many of the species are represented by only one or few specimens. This is in marked contrast to some of the other mesofossil floras from Portugal. Those sediment samples were often rich, sometimes providing several thousand exceptionally well preserved, often charcoalified, mesofossils.

All 11 samples from the lower member of the Almargem Formation are similar in the relatively sparse mesofossil assemblage that they contain and in the small size of the fossils recovered. Two of the samples, Torres Vedras sample 43 and Torres Vedras sample 44, yielded the largest number of specimens and the most species. Most of the fossils described here are from these two samples. The other samples collected from Torres Vedras (TV38, TV39, TV142, TV143, TV144, TV145, TV217, TV298, TV299) contain fewer specimens and fewer species.

The samples are broadly similar in the major plant groups represented, but they differ markedly in the kinds of organs recovered, the quality of their preservation, and the composition of the overall plant assemblage. For instance, in sample TV43 most of the fossils are seeds or megaspores, while sample TV44 has yielded almost all the stamens. A total of 104 taxa have been identified from the Torres Vedras samples (Text-fig. 56), but the number of taxa shared between samples is low. Only nine of the angiosperm species identified occur in both TV43 and TV44 (Tab. 1). The fossils are mostly preserved as lignite, but in some samples (e.g. TV39) natural maceration of some of the plant fragments has apparently left only the more resistant cutinized outer layers. Only in a few cases are the fossils preserved as charcoal.

Our study focused particularly on the angiosperm fossils and chlamydospermous seeds in the mesofossil flora, discriminating them as far as possible at the species level. Remains of spore-bearing plants and conifers were not as finely discriminated. Consequently, the number of taxa in these groups may be somewhat underestimated, although there is no evidence of substantially greater diversity than that recognized in the systematic accounts given above.

Although only about $18 \%$ of the specimens that we identified can be attributed to angiosperms, together they account for about $62 \%$ of all species recognized in the mesofossil assemblage. Most abundant in terms of plant fragments identified, are spore-bearing plants, which comprise about $34 \%$ of all specimens recovered. Many of these fossils are megaspores. Conifers are also quantitatively important and comprise about $29 \%$ of all plant fragments isolated from the samples. Chlamydospermous seeds (BEGs) account for about $18 \%$ of all plant fragments.

Note that four specimens briefly described and illustrated previously (Friis et al. 1994: fig. 9a-f, Friis et al. 2004: fig. 3A-C) are from the Puddledock flora, Virginia, USA (Puddledock sample 149), and not from Torres Vedras as stated in these studies.

\section{Angiosperms}

Angiosperms are the most diverse group in the Torres Vedras mesofossil flora (64 species) and comprise more than half of the species identified. The actual number of biological species represented may be fewer because we expect that some of the stamens and pollen clumps may be part of the 

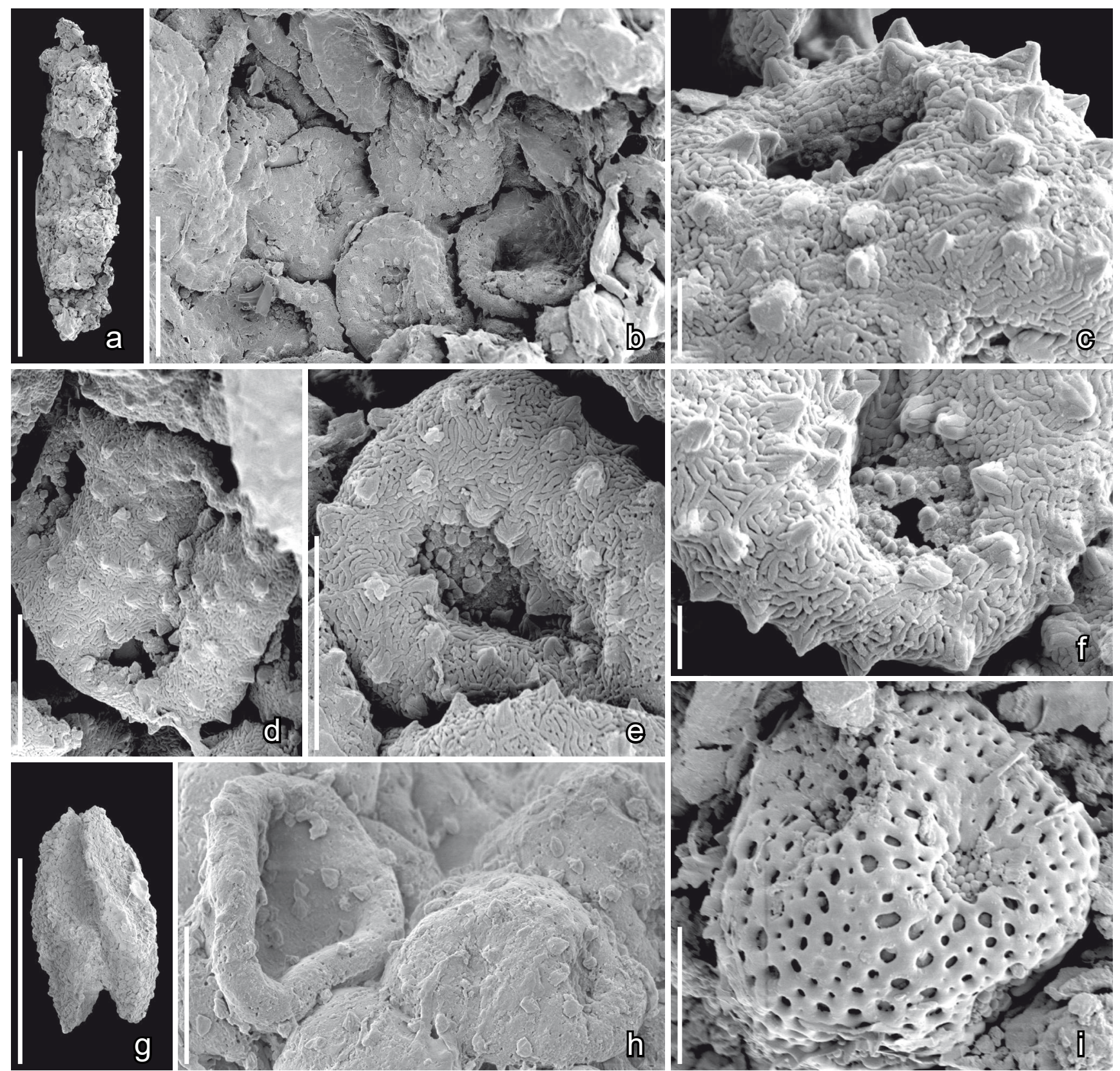

Text-fig. 55. Scanning electron microscope (SEM) images of stamen fragments and pollen of Ibrahimia verminculata (a-h) and unnamed pantoporate pollen from pollen clump (i); Torres Vedras locality, Portugal. a) Holotype; stamen fragment that yielded the pollen in (b-f); b-f) Pantoporate pollen grains with vermiculate tectum and regularly spaced microechinate and pores with verrucate aperture membranes; g) Stamen fragment that yielded the pollen in (h); h) Abraded pantoporate pollen with vermiculate tectum and regularly spaced microechinate; i) Pantoporate pollen from coprolite with microreticulate-foveolate tectum and verrucate aperture membranes. Specimens, TV44-S148019 (holotype; a-f), TV44- S136782 (g, h), TV142-S170216 (i). Scale bars $300 \mu \mathrm{m}(\mathrm{a}, \mathrm{g}), 15 \mu \mathrm{m}(\mathrm{b}), 6 \mu \mathrm{m}(\mathrm{d}, \mathrm{e}, \mathrm{h}, \mathrm{i}), 1.5 \mu \mathrm{m}(\mathrm{c}, \mathrm{f})$.

same plants as some of fruits and seeds, but we have been unable to hypothesize any specific linkages beyond those discussed above. Of the 64 species recognized, 22 species are described from sample TV43, based mainly on seeds and fruits, while 38 species are described from sample TV44 of which many (20 species) are stamens or clumps of pollen composed of a single kind of pollen grain.

Systematically, 50 of the angiosperm species can be assigned to non-eudicot angiosperms (ANA-grade, eumagnoliids, monocots). Only three can be assigned unequivocally to eudicot angiosperms based on their tricolpate pollen. Eleven angiosperm species cannot be assigned to eudicot or non-eudicot angiosperms due to lack of evidence from pollen occurring in situ or adhering to stigmatic regions, or from other diagnostic features. Of the 39 different pollen types identified from the mesofossil assemblages 33 are monocolpate grains (Text-fig. 57).

Taxa related to ANA-grade angiosperms include species assigned to Anaspermum, Gastonispermum and Pazliopsis, as well as several unnamed species that are thought to be closely related to extant Nymphaeales-Austrobaileyales. These fossils share features with extant Nymphaeales and Illiciaceae. Their more precise systematic position with respect to extant taxa cannot be determined based on the 
evidence currently available and they likely represent extinct taxa close the point of divergence of these extant groups.

Prominent among the angiosperm remains are fruits, seeds, stamens and pollen of chloranthoid affinity, including species assigned to Asteropollis, Canrightia, Clavatipollenites, Hedyflora and Kvacekispermum. Asteropollis and Hedyflora are likely on the stem group of extant Hedysomum (Friis et al. 2019b), while Canrightia, and perhaps Clavatipollenites, and Kvacekispermum establish the presence of the clade that includes extant Ascarina, Chloranthus and Sarcandra (Friis et al. 2015b).

Eumagnoliid angiosperms include species of Serialis, and probably also the Appomattoxia complex, which includes species of Appomattoxia, Appofructus, Burgeria, Dejaxia and Goczania. Fruits and seeds of Serialis are the earliest fossils that can be assigned to Magnoliales. However, they differ from all extant members of the order and cannot be assigned to any of the extant families. Serialis is common in Early Cretaceous mesofossil floras from Portugal, but Serialis antiqua, unique to the Torres Vedras mesofossil flora, is distinguished from all other species of the genus by its decurrent stigma (Friis et al. 2019a). Species of Appomattoxia, Appofructus, Burgeria, Dejaxia and Goczania, which are thought to be related to extant Piperales (see Systematic palaeobotany), are also diverse among the Torres Vedras mesofossils. Our work on other mesofossil floras from Portugal and eastern North America suggests that this group of extinct angiosperms was widespread in the Early Cretaceous vegetation.

An interesting feature of the Torres Vedras mesofossil flora is that monocots do not appear to be an important component. Currently monocots are represented only by pollen of Mayoa, and possibly by fruits and stamens of the Pennistemon plant (Pennicarpus, Pennipollis).

In addition to the fossils of non-eudicot angiosperms summarized above there are about 17 other non-eudicot species, as indicated by the monocolpate pollen that occurs within stamens or adhering to stigmatic surfaces, but none of these non-eudicot species can be placed definitively among eumagnoliid or ANA-grade angiosperms. Among these species are several that have often been assigned to the dispersed pollen genus Retimonocolpites, even though these pollen grains are distinctly different from the type species of that genus (see Systematic palaeobotany). This group of taxa includes species assigned here to the new genera Choffaticarpus, Dictyozonia, Dinisia, Eckhartia, Eckhartianthus, Eckhartiopsis, Juhaszia, Kempia, Piercipollis, Teebacia and Vedresia. These taxa can be distinguished based on stamen and/or pollen morphology, including the ornamentation of the reticulum of the pollen wall and associated orbicules. Choffaticarpus, Eckhartianthus and Vedresia can also be distinguished by other floral features. Choffaticarpus has an apocarpous gynoecium of many, densely spaced carpels, Eckhartianthus has a tricarpellate and syncarpous gynoecium, and Vedresia was apparently monocarpellate.

It is possible that some of these 17 species of non-eudicot angiosperms are monocots. For example, Eckhartianthus has trimerous floral organization and both Juhaszia portugallica and Dictyozonia pusilla are characterized by pollen with a graded reticulum and smooth muri, features that have been suggested as typical for monocot pollen (Walker and Walker 1984, 1986). Other possible defining features of monocot pollen highlighted by Walker and Walker (1984) include "strongly dimorphic lumina within an otherwise relatively coarse reticulum", "frilled muri due to slightly protruding of columellae past the edges of the muri", "a relatively thin nexine and thick tectum" and "apparent lack or little development of endexine". Pollen with frilled muri have not been observed among the fossils from Torres Vedras, but dimorphic lumina within a relatively coarse reticulum and poorly developed endexine occur in species of Eckhartia and also in pollen of Eckhartiopsis parva. However, some of these features were apparently also present among pollen of ANA-grade angiosperms and eumagnoliids. For example, species of Anacostia E.M.FriIs, P.R.CRANE et K.R.PEDERSEN have trichotomocolpate pollen with a distinctly graded reticulum that resembles that of monocot pollen (Friis et al. 1997), but the seeds have an embryo with two cotyledons (Friis et al. 2015a).

A distinctive feature of the Torres Vedras mesofossil flora, which is significant for comparison with palynofloras and also other mesofossil floras from the Early Cretaceous, is that eudicots are a very minor component. Eudicots are represented by only three specimens, assigned to three different new genera, Mcdougallia, Nicholsia and Samylininaea. All three of the Torres Vedras tricolpate pollen genera are tectate-perforate or microreticulate-perforate. None is striate or coarsely reticulate as is common in tricolpate pollen from younger palynofloras (Penny 1988a, Pedersen et al. 2007, Horikx et al. 2016).

Among the unassigned angiosperm fossils are two species with pantoporate pollen, Ibrahimia and an unnamed type. Such pollen is clearly angiospermous, but occurs both among non-eudicot and eudicot angiosperms so these fossils cannot be placed more precisely with the data currently available. There are also several fruits and seeds with distinct angiosperm features that cannot be placed with certainty in any major group of extant angiosperms.

The diverse angiosperm component of the Torres Vedras mesofossil flora contrasts sharply with the representation of angiosperms in the dispersed palynoflora from the same horizon that was studied by Konradsen (1996). Only sporadic grains of Clavatipollenites and Pennipollis were observed in the palynoflora, and neither genus was captured in the pollen counts. Clavatipollenites and Pennipollis, together with a single grain of Mayoa portugallica, are also the only angiosperm pollen grains reported from the Casal do Borracho palynoflora, which was isolated from sediments collected close the Torres Vedras mesofossil site, and was apparently also from the lower member of the Almargem Formation (Mendes et al. 2018).

\section{Bennettitales-Erdtmanithecales-Gnetales}

Four different kinds of chlamydospermous seeds occur in the Torres Vedras mesofossil flora and are assigned to four different genera, Buarcospermum, Ephedrispermum, Quadrispermum and Tomcatia. These four genera belong to the diverse Early Cretaceous BEG complex, which includes plants closely related to extant Gnetales, as well as to extinct Erdtmanithecales and Bennettitales (Friis et al. 2009, 2013, 


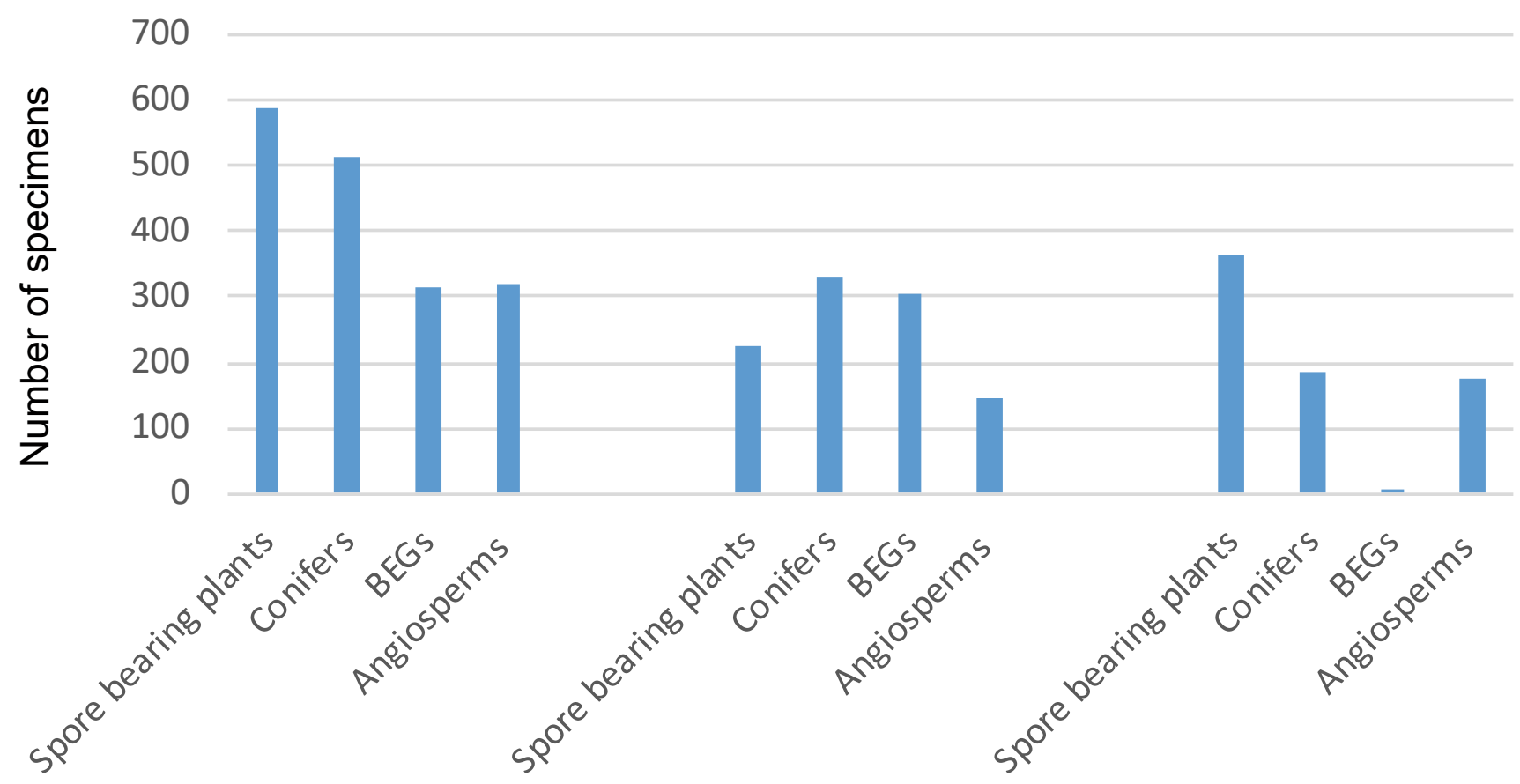

Torrres Vedras all samples Torres Vedras 43

Torres Vedras 44

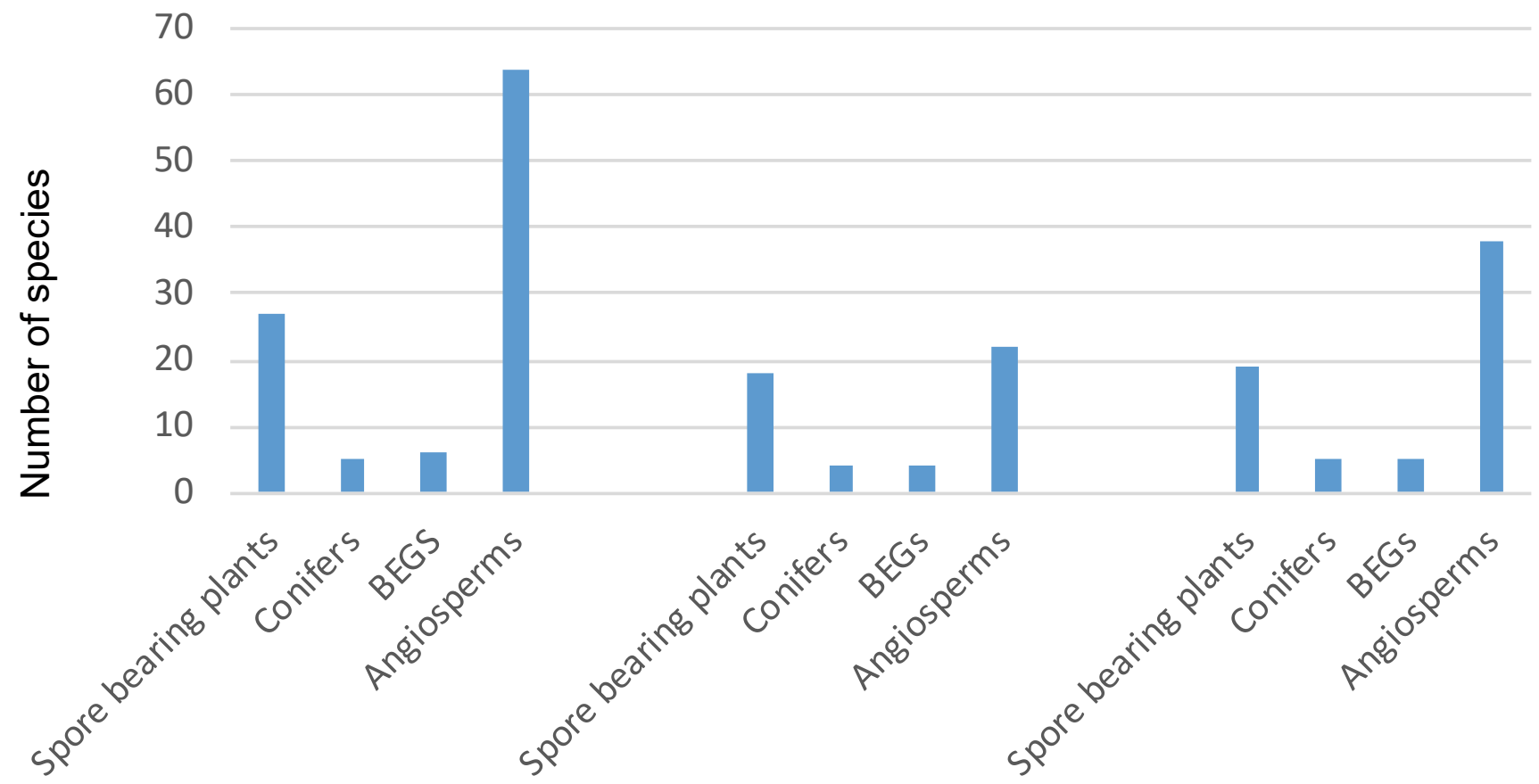

Text-fig. 56. Number of specimens and number of species for the four major plant groups recovered in the Torres Vedras mesofossil flora. Unidentified specimens such as seed fragments, stamen fragments without pollen grains, coprolites without recognizable plant fragments and strongly distorted specimens are not included in this overview.

2019c). The distribution of the four BEG species is very uneven between the two Torres Vedras samples. More than 300 BEG specimens were recovered from sample TV43. Only three specimens were recovered from sample TV44 (Text-fig. 56).

Potentially interesting for future work on the BEG group is the monocolpate pollen associated with Quadrispermum, as well as pollen of the Exesipollenites-like type and the pollen grains assigned to Sergipea. All may have been produced by plants belonging to the BEG complex. More information about the plants that produced these grains, as well as the plants that produced Buarcospermum, Quadrispermum and Tomcatia, will be important for a better understanding of the systematics and ecology of these plants 
1-monoaperturate-reticulate (26 types)

2-monoaperturate-tectate (7 types)

3-monoaperturate-striate ( 1 type)

4 -tricolpate (3 types)

$5-$ pantoporate (2 types)

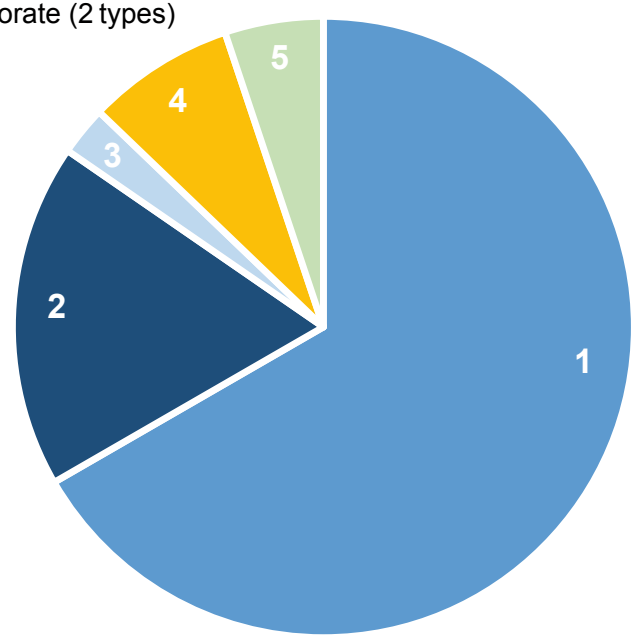

Text-fig. 57. The distribution of aperture and tectum types among the 39 different kinds of angiosperm pollen encountered in the Torres Vedras mesofossil flora.

that had distinctive seeds and that are often associated with angiosperms in Early Cretaceous mesofossil floras.

\section{Conifers}

Conifer fragments are among the most common plant fossils in the Torres Vedras mesofossil flora, but the diversity of species appears to be low. The few species identified are mainly seeds, fragments of Brachyphyllumtype leafy shoots, pollen sacs and clumps of pollen with Araucariacites-type pollen, as well as pollen sacs and pollen clumps with bisaccate pollen. It is noteworthy that conifer remains referable to the family Cheirolepidiaceae are extremely rare in the Torres Vedras mesofossil flora. Only a single, poorly preserved axis of Pseudofrenelopsis has been recovered and pollen of Classopollis has not been recovered from the mesofossil flora. The sparse presence of Cheirolepidiaceae is also reflected in the low recovery of Classopollis in palynological preparations from the Torres Vedras locality (Konradsen 1996), and their similarly low representation in the possibly contemporaneous Casal do Borracho palynoflora (Mendes et al. 2018).

\section{Spore-bearing plants}

Remains of spore-bearing plants are common among the plant mesofossils from Torres Vedras. They are especially prominent in sample TV44 where they constitute half of all the specimens counted and about $28 \%$ of all species in the sample. Most of these remains of spore-bearing plants are lycopodiopsid megaspores. Megaspores of Erlansonisporites, Rugotriletes and Striatriletes, all probably related to Selaginellales, are particularly abundant in sample TV44. Megaspores probably related to Isoetales, such as Tenellisporites, Dijkstraisporites and Paxillitriletes are rare. Megaspores of Salviniales (Molaspora and Arcellites) are unevenly distributed among the samples from Torres Vedras and none has been found in sample TV44. Megaspores of Molaspora are rare in most samples, while megaspores of Arcellites occur abundantly in some samples, such as TV38 and TV43. Isoetalean and salvinialean megaspores are both thought to have been produced by aquatic or wetland plants, but there is no apparent correlation between the occurrences of these different megaspores in the samples.

In addition to megaspores of water ferns, other fern remains are common and diverse among the mesofossils. In a few cases the sporangia, or the spores themselves, have distinctive features that place them securely in an extant family, for example, Cicatricosisporites type spores are characteristic of extant Schizaeaceae. However, the systematic affinity of other spores is less certain and some, for example spores of Patellasporites, may have been produced by bryophytes. A distinctive component of some of the Torres Vedras samples are small axes of probable marchantialean liverworts.

\section{Discussion}

\section{Comparison of the Torres Vedras mesofossil flora and palynoflora}

The floristic composition of the Torres Vedras mesofossil flora, with its dominance of angiosperm species, is in distinct contrast to the composition of the palynoflora recovered from the same level, where about two thirds of the taxa are spore-bearing plants. Only two angiosperm taxa, Clavatipollenites hughesii COUPER and Pennipollis peroreticulatus (G.J.BRENNER) E.M.FrIIS, K.R.PedERSEN et P.R.CRANE, were reported from the palynoflora, and only one of these, Clavatipollenites hughesii, is reported from the palynological preparation made from sample TV44 (Konradsen 1996) that yielded most of the angiosperm pollen types recovered from the mesofossil flora. No tricolpate pollen was reported from the palynological preparations of sample TV44, or in the palynogical preparations from other samples collected at this level from Torres Vedras (Konradsen 1996). These results are also consistent with those from the possibly contemporaneous Casal do Borracho palynoflora collected very close to our mesofossil site. Only three angiosperm genera, Clavatipollenites, Mayoa and Pennipollis, were reported from this palynoflora that is otherwise dominated by spore-bearing plants (Mendes et al. 2018).

A similar pattern has been observed for other Early Cretaceous floras in Portugal where both microfossils and mesofossils have been studied (Mendes et al. 2014, Mendes and Friis 2018; Friis, Crane and Pedersen, unpublished data). That palynofloras underestimate angiosperm diversity in Cretaceous vegetation was also noted by Lidgard and Crane (1990) in their large-scale analysis that compared 91 macrofossil floras and 860 palynofloras spanning the entire Cretaceous. While palynofloras provide a broad insight into the appearance and distribution of angiosperms because of their unrivalled geographic and stratigraphic sampling, mesofossil and macrofloras provide more insight into the importance of angiosperms at specific localities.

Stratigraphic evidence (Rey 1993, Dinis 2001, Dinis et al. 2002, Rey et al. 2006) indicates that the fossil flora from 
the lower member of the Almargem Formation at Torres Vedras is the oldest mesofossil flora known from Portugal, and also the oldest mesofossil flora worldwide, in which angiosperms are present. This is also consistent with the sparse representation of eudicots, and the close similarity of taxa in the mesofossil flora and palynoflora to taxa described from Berriasian to Aptian strata (see Systematic palaeobotany).

\section{Macrofossil floras from the Torres Vedras region}

Macrofossil floras from the Torres Vedras region have been known for more than 100 years and are described from many localities (Heer 1881, Saporta 1894, Teixeira 1948). The most important of these macrofloras are from localities to the north and northeast of Torres Vedras, and several are from exposures along the railway line between Torres Vedras and Outeiro da Cabeça. These macrofossil floras are rather uniform in composition and are dominated by ferns, while conifers are typically subordinate. Several taxa reported by Saporta (1894) as angiosperms, such as species of Poacites Brongn., were later assigned to Podozamites BRAUN, a genus with putative conifer affinities (Teixeira 1948). While the macrofloras previously described from the Torres Vedras area may be contemporaneous with the Torres Vedras mesofossil flora, the old localities can no longer be collected and their stratigraphic position cannot be determined securely. Mesofossil samples collected in the same areas had only poorly preserved plant remains and all lacked angiosperms.

\section{Palaeoenvironment}

During the Early Cretaceous Portugal was situated close to the southern border of the Cerebropollenites palynofloral province that extended across most of the Northern Hemisphere, including North America, Europe and Asia, but excluding Italy, India and the IndonesianPhilippine archipelago (Herngreen et al. 1996). The province is named for the distinctive polysaccate conifer pollen, Cerebropollenites macroverrucosus (THIERGART) EBE.Schulz, that is widespread and common in palynofloras from this region and that is also present in the Torres Vedras samples (Konradsen 1996). The palynoflora from Torres Vedras is also consistent with the general characterization of the Cerebropollenites province, both in terms of taxa recorded and general floristic composition (Konradsen 1996). Results from the Torres Vedras mesofossil flora therefore provide useful insights for interpreting the vegetation of much of the Northern Hemisphere during the Early Cretaceous.

During the Early Cretaceous the Iberian Peninsula was toward the southern boundary of the Cerebropollenites palynofloral province close to the northern boundary of the equatorial region. During the Berriasian - Aptian the equatorial region is included in the Dicheiropollis etruscus/ Afropollis palynofloral province, and during the Albian in the Elaterates palynofloral province (Herngreen et al. 1996). The Torres Vedras mesofossil flora indicates that a few taxa typical of the equatorial zone were also present further north. Sergipea, related to the Elaterates group provides the best example. It was previously reported in Europe from the Barremian stratotype at Angles, southern France, where it occurs in the middle interval of the late Barremian part of the section (Renéville and Raynaud 1981). To our knowledge a report from the Glenrose locality in Texas, USA, dated as lower Albian, is the only other prior report of Sergipea from the Cerebropollenites palynofloral province (Tanrikulu et al. 2018).

Another possible equatorial element is the pollen described here as a non-angiosperm plant of unknown affinity (see Systematic palaeobotany), which may be related to the characteristic equatorial taxon Dicheiropollis etruscus. Afropollis, which is characteristic of the equatorial region during the Aptian has not been recorded at Torres Vedras, although the semitectate-reticulate pollen with sharp muri (p. 226 herein) may be a related form. Otherwise Afropollis is known in Portugal from the late Aptian-early Albian mesofossil floras of Vale de Água (Friis et al. 1999) and Nossa Senhora da Luz (Mendes and Friis 2018). Afropollis, and several different taxa assigned to the Elaterates group, have also been reported outside the equatorial province from the Cenomanian of the Czech Republic (Pacltová and Lashin 1999).

Although angiosperms are diverse in the Torres Vedras mesofossil flora they are quantitatively subordinate and very few angiosperm taxa are shared among the different samples. This uneven distribution is also pronounced for other groups. For example, sample TV44 yielded only three BEG specimens, while hundreds of BEG seeds were recovered from sample TV43. Similarly, while only two Erlansonisporites megaspores were recovered from sample TV43, sample TV44 yielded 94 specimens of this very distinctive megaspore.

The reasons for the marked differences in the floristic composition of different samples are probably complex, but may indicate that the individual samples were derived from different patches of local vegetation that were dominated by ferns, conifers and members of the BEG group, but that also contained scattered angiosperms. However, differences in the local source vegetation may also have been amplified by the differential seasonal production of flowers and fruits, as well as processes of pre-depositional sorting and reworking. Disentangling these factors based on the information available is not straightforward. For example, the predominance of stamens in sample TV44 may indicate differential transport of lighter plant fragments, or an influx of plant material shortly after flowering. Similarly, sample TV43, which has more fruits and seeds, could reflect transport of heavier plant fragments with slightly increased depositional energy, or a seasonal increase in the abundance of diaspores. However, on the whole, we think it unlikely that sorting was marked or that the very small size of the angiosperm remains reflects the winnowing out of larger plant parts. Large pieces of wood were present in the original samples, and in all of the many mesofossil floras that we have examined from the Early Cretaceous of Portugal and eastern North America, including that from Torres Vedras, angiosperm remains are generally tiny.

The warm, seasonally dry, climate inferred for western Europe during the mid-Early Cretaceous (Ruffell and Batten 1990, Gale 2000) is consistent with the small scale-like leaves of the Brachyphyllum type conifers in the Torres Vedras mesofossil flora, and also in the macrofossil floras 
from the Torres Vedras region, which are dominated by scale-leaved conifers and ferns with tiny leaves (Saporta 1894, Teixeira 1948). The presence of ephedroid plants (Ephedrispermum lusitanicum) also points toward seasonal aridity, as do the three species of Cicatricosisporites, which are related to the extant schizaeaceous fern Anemia, an extant genus that is distributed mainly in the warmer and drier regions of America from Texas to Argentina (Kramer 1990). At the same time, the presence of Charales, Isoetales and Salviniales indicates at least ephemeral shallow, nonturbulent, water bodies.

The overall picture that emerges from the mesofossil flora, including from the predominance of ferns, is of relatively open vegetation perhaps bordered by more closed conifer dominated forest in the more stable parts of the flood plain. Angiosperms by contrast, and perhaps some members of the BEG group, were low stature opportunists colonising less stable disturbed environments, including near ephemeral ponds and streams. The small size of the angiosperm seeds and their inferred tiny embryos is also consistent with the hypothesis that the angiosperms were early successional colonizers of disturbed habitats (Hickey and Doyle 1977, Friis et al. 2015a).

The underrepresentation of angiosperm pollen in the palynological samples compared to the mesofossil flora suggests that angiosperms in the Torres Vedras mesofossil flora were probably insect pollinated plants, with only modest production of pollen grains that had low dispersal potential. The angiosperm pollen grains that occur more commonly in dispersed palynofloras, such as the chloranthoids Asteropollis and Clavatipollenites, were most likely wind pollinated and had higher pollen production, as also occurs in their closest extant relatives, Hedyosmum and Ascarina. The tectate-microechinate pollen of the GoczaniaDejaxia group is also suggestive of wind pollination.

\section{Comparison with other Early Cretaceous meso- and microfossil floras}

The Early Cretaceous mesofossil floras reported from Portugal and eastern North America that contain angiosperms (e.g. Friis et al. 2011) range in age from the late Barremian-Aptian through to early Cenomanian. Earlier mesofossil floras which lack angiosperms have also been collected from the earliest Cretaceous in Portugal and range in age from Berriasian to early Barremian. Although none of these floras have been studied in the same detail as that from Torres Vedras they have all been prepared and studied in the same way and comparison among them is therefore relatively straightforward.

Comparison with dispersed pollen is more problematic as most illustrations are typically based on light microscopy (LM) that in many cases are insufficient for detailed systematic comparison. Our palynological comparisons therefore focused mainly on publications based on SEM studies (e.g. Hughes et al. 1979, Chapman 1986, Penny 1986, 1988a, b, 1989, 1991, Ward 1986, Hughes and McDougall 1987, 1990, Hughes 1994, Ibrahim 2002, Schrank and Mahmoud 2002, Dejax et al. 2007, VillanuevaAmadoz et al. 2010, Schrank 2017), but we have also made comparisons with palynofloras from Portugal studied using
LM alone (e.g. Groot and Groot 1962, Konradsen 1996, Heimhofer et al. 2007, Horikx et al. 2016). The stratigraphic and geographic coverage of SEM-based studies is not as extensive as the coverage based on LM, but together these studies provide a broad framework for stratigraphic inferences and palaeocological interpretations.

Mesofossils collected from several localities in Early Cretaceous formations stratigraphically below the Almargem Formation floras (e.g. Ladeira, Os dos Imãos, Santa Suzana, São Lourenço, Serreira; Berriasian-early Barremian; Friis, Crane and Pedersen, unpublished) lack angiosperms and are mostly dominated by remains of ferns and conifers (see also Mendes et al. 2011). Younger mesofossil floras with angiosperm remains, including the Arazede, Buarcos, Catefica, Famalicão, Juncal, Vale de Água and Vila Verde floras, typically have a much more diverse angiosperm component than the Torres Vedras mesofossil flora, and angiosperm remains are also much more abundant. In the Torres Vedras mesofossil assemblages most angiosperm species are represented by one or few specimens, and only Anaspermum, Clavatipollenites, Eckhartia, Hedyflora, Pazliopsis, Serialis and Teebacia are represented by more than 10 specimens. In other mesofossil floras, and especially in the Famalicão mesofossil flora, some angiosperm species may be represented by several hundred specimens (Friis et al. 2019a). Angiosperms appear to have been much more prominent in this later vegetation than in the more ancient Torres Vedras flora.

Most of the angiosperm taxa described from Torres Vedras are currently known only from this mesofossil flora. However, several of the genera present at Torres Vedras occur in younger sediments and are also geographically widespread. Among these genera are Pennicarpus and Pennipollis, which are reported from several other Early Cretaceous mesofossil floras from Portugal. Dispersed Pennipollis pollen is widely distributed in the Cerebropollenites floral province, and also occurs in equatorial regions.

Present at Torres Vedras, and also in other Early Cretaceous mesofossil floras from Portugal, are the chloranthoid angiosperms Asteropollis, Canrightia, Clavatipollenites and Hedyflora. Canrightia elongata from Torres Vedras is clearly distinct from Canrightia resinifera described from the Arazede, Buarcos, Catefica, Famalicão, Vale de Água and Vila Verde localities. Flowers/fruits of Hedyflora from Torres Vedras are closely similar to specimens from Buarcos and Catefica, but the preservation of the Hedyflora specimens from Torres Vedras does not allow comparison at the specific level with material from other floras. The apparent conspecificity of the various Asteropollis and Clavatipollenites type pollen grains from Torres Vedras, with those from other mesofossil floras, also remains to be investigated in detail.

At the specific level megaspores of Molaspora sp. and Arcellites punctatus, seeds of Buarcospermum tetragonium and Tomcatia taylorii, and fruits of Choffaticarpus compactus, are known in Portugal only from the Torres Vedras, Buarcos and Catefica mesofossil floras, while Ephedrispermum lusitanicum and Serialis parva are shared between the Torres Vedras and the Buarcos mesofossil floras. Angiosperm seed sp. 3 also occurs at Buarcos, and Catefica, as well as at Arazede. In general, Buarcos and Catefica are 
the two mesofossil floras that show the greatest similarity to that from Torres Vedras, although many taxa that are recorded at Buarcos, Catefica and in other mesofossil floras, for example Saportanthus, Canrightiopsis, Anacostia and Riaselis, are missing from Torres Vedras.

Among Early Cretaceous mesofossil floras from eastern North America, two floras, the Kenilworth and the Puddledock flora from the early-middle Albian of Maryland and Virginia respectively are particularly rich including thousands of specimens and numerous species of angiosperms (e.g. Crane et al. 1994). Although many angiosperm taxa from these floras have already been described and formally named (e.g. Friis et al. 1994a, 1995, 1997, 2016, 2018a, c, d, von Balthazar et al. 2007, 2008, 2011), most remain undescribed.

The Albian mesofossil floras from Kenilworth and Puddledock are distinguished from that at Torres Vedras by their much more diverse angiosperms, their much greater number of eudicot taxa, and the greater morphological diversity of tricolpate pollen grains in the mesofossil flora. It is interesting that some of the samples from the Puddledock locality (e.g. Puddledock sample 04 and 73; Crane et al. 1994), like Torres Vedras sample 44, were unusual in yielding many isolated stamens. However, the stamens from Puddledock typically have extensive connective tissue, often at the apices of the anthers or between anthers (Friis et al. 2011). In contrast, the stamens from Torres Vedras are typically tiny and lack any expansion of the connective. A similar difference in stamen morphology, most likely related to pollination biology, is also seen when the stamens from Torres Vedras are compared with those from the Catefica locality, which has also yielded many stamens (Friis et al. 2011).

Only a few taxa are shared between the Torres Vedras mesofossil flora and Early Cretaceous palynological assemblages from coastal sections in Portugal, but all of these shared taxa have occurrences in the Aptian parts of the coastal sections (see Systematic palaeobotany). Sediments from the Luz section on coast of the Algarve range in age from early Aptian to early Albian (Heimhofer et al. 2007), the Cresmina section on the Atlantic coast west of Lisbon ranges in age from late Barremian to the middle Albian (Heimhofer et al. 2007), and the São Julião section ranges in age from early Albian to early Cenomanian (Horikx et al. 2016). Comparison with the palynological assemblages from these coastal sections is consistent in suggesting a preAlbian age for the Torres Vedras flora.

The São Julião palynological assemblages are clearly distinct from that of Torres Vedras, particularly in the high proportion of tricolpate pollen with a high taxonomic and morphological diversity. This is also the case for the Albian parts of the Cresmina and Luz sections. The monocolpate pollen taxa are also different and all three sections include several species of Dichastopollenites F.E.MAY that are unknown in the Torres Vedras assemblage. It is also interesting that Albian-early Cenomanian Asteropollis grains from the São Julião section are typical Asteropollis asteroides with a pentachotomocolpate aperture, while the early Aptian-early Albian grains of Asteropollis cf. asteroides from the Luz and Cresmina sections, like those from Torres Vedras flora, are tetrachotomocolpate.

\section{Implications for angiosperm evolution}

The Torres Vedras mesofossil flora is important in being the earliest mesofossil flora with angiosperm remains currently known. It provides evidence of floral structure and organization, reproductive biology, and angiosperm systematic diversity at an early stage in angiosperm evolution that corresponds to phases 4 and 5 in the stratigraphic framework for the earliest phases of the angiosperm radiation suggested by Hughes (1994) based on fossil pollen from the Early Cretaceous of England. By this time angiosperms had already achieved some diversity, but knowledge of angiosperms in pre-Barremian (Valanginian - Hauterivian) is provided only by isolated pollen grains (Trevisan 1988, work in progress, Brenner and Bickoff 1992, Hughes 1994, Brenner 1996).

All pollen grains from phases 1, 2 and 3 of Hughes (1994) are monocolpate. It is not until phase 4 and 5 (late Barremianearly Aptian) that the first, scarce tricolpate pollen grains are recorded in the dispersed palynofloras (Hughes and McDougall 1990) approximately contemporaneously with deposition of the Torres Vedras mesofossil flora. Compared to the angiosperm content in dispersed palynofloras the taxonomic diversity of the Torres Vedras mesofossil flora is surprising high, but it is interesting that almost all of this diversity is at the level of ANA-grade angiosperms, eumagnoliids and in a few cases early diverging lineages of monocots and eudicots.

Most of the angiosperm pollen grains recovered in the Torres Vedras mesofossil flora are monoaperturate, mostly monocolpate, and more rarely tetrachotomo- or trichotomocolpate. Chloranthoid pollen grains assigned to Clavatipollenites and Asteropollis belong to this category and are especially prominent in the early angiosperm pollen record. Chloranthoids are also the most diverse group among the Torres Vedras mesofossils with about ten species in five genera (Asteropollis, Canrightia, Clavatipollenites, Hedyflora, Kvacekispermum). Chloranthoids continued to diversify during the Early Cretaceous, were important in the later part of the Early Cretaceous, but declined during the Late Cretaceous.

Chloranthaceae are currently the only extant angiosperm family that can be recognized at this early stage in the angiosperm radiation. However, during the Early Cretaceous, the Chloranthaceae were clearly more diverse than is indicated by four extant genera of the family. The extinct genera of Chloranthaceae, Canrightia, Canrightiopsis, Hedyflora and Kvacekispermum, appear to have been short lived. Like most of the other Early Cretaceous angiosperms known from Torres Vedras, there is currently no evidence of them after the mid-Cretaceous.

Eudicot angiosperms are very rare in the Torres Vedras flora. They were recorded only from the mesofossil flora, and were not encountered in the Torres Vedras palynoflora. Their low morphological and taxonomic diversity most likely represents a very early stage in eudicot diversification, which is also reflected in the apparent developmental instability of the colpi. There is no indication of diverse eudicots among the Torres Vedras angiosperms. This is also consistent with the eudicot angiosperms identified in younger mesofossil assemblages from the Early Cretaceous of 
Portugal, all of which have features indicating relationships with Ranunculales and other basal grade eudicots, including Buxales (von Balthazar et al. 2005, Pedersen et al. 2007, Friis et al. 2018e).

The patterns that emerge from our studies of the Torres Vedras flora and other mesofossil assemblages from Portugal and eastern North America strongly corroborate previous results based on dispersed pollen and leaves, of an orderly appearance of successively more derived angiosperm groups during the Early Cretaceous (Doyle and Hickey 1976, Hickey and Doyle 1977, Friis et al. 2011, Herendeen et al. 2017, Coiro et al. 2019). While it remains possible that fossils of crown group angiosperms will be discovered in the earliest Cretaceous (Berriasian), or perhaps even earlier in the Jurassic, none of the supposed pre-Cretaceous angiosperms currently described are fully convincing and some are clearly misinterpretations of poorly preserved material (Herendeen et al. 2017).

The Torres Vedras mesofossil flora highlights the extent to which studies of palynofloras, especially studies based solely on light microscopy, may underestimate the diversity of early angiosperms that existed in the earliest phases of their diversification, but this additional diversity does not change the overall pattern. The consistency of the overall stratigraphic pattern, as revealed by observations from many palynofloras, mesofossil floras and macrofossil floras, makes it very unlikely that the angiosperm crown group, except perhaps taxa at the ANA grade, are more ancient than the Valanginian-Hauterivian. Extrapolations based on molecular clock techniques that suggest much earlier divergences require careful scrutiny and should be treated with caution.

The mesofossil record from Torres Vedras and other localities highlights the extent of extinction and the complex histories of many of the key early diverging clades of angiosperms that today are relatively species poor. For example, the six living genera and ca. 75 living species of extant Nymphaeales are merely the most recent manifestation of a long a complex clade history (Friis et al. 2011). This history included, at a minimum, considerable extinct diversity in the Early Cretaceous and early Cainozoic, and a still more recent differentiation of species within several extant genera.

A further interesting, and perhaps significant observation from the standpoint of angiosperm evolution, is the very small size of all the angiosperm flowers, fruits and seeds from the Torres Vedras assemblage. This is also the case in the other Aptian - Albian mesofossil floras from Portugal and eastern North America that we have studied. Even allowing for some degree of shrinkage during fossilization (Lupia 1995), the small size of angiosperm reproductive structures is a striking and consistent feature that is also seen in the rare macrofossil remains of similar age (Taylor and Hickey 1990, Leng and Friis 2003, Krassilov and Volynets 2008, Golovneva et al. 2018). It is possible that there may be some relationship to genome size or other developmental factors. However, flowers, fruits and seeds of small size are also characteristic of many angiosperms during the Late Cretaceous (Friis et al. 2011), and may reflect a variety of biological or ecological factors.

\section{Conclusions}

The fossil flora from Torres Vedras is the oldest mesofossil flora containing angiosperm remains to be described in detail based on well-preserved flower, fruit and seed remains. It provides the most detailed information currently available on the structural diversity of angiosperms at this early stage in their evolution, the range of angiosperm species present, and their relationships to extant angiosperm lineages. The mesofossils from Torres Vedras also give information on the abundance of angiosperms compared to fossils of other groups of plants, and therefore a general indication of the importance of angiosperms in mid-Early Cretaceous vegetation.

The insights provided by the Torres Vedras mesofossil assemblage are complementary to the information on early angiosperm evolution provided by studies of dispersed angiosperm pollen grains in palynofloras, and by angiosperm leaf remains in macrofloras. While data from palynofloras provide extensive geographic and stratigraphic sampling (Crane and Lidgard 1990), most are studied using only light microscopy, which lacks the resolution needed to discriminate important fine structural details that can be observed using scanning electron microscopy. Similarly, while studies of the physiognomy of angiosperm leaves in macrofloras (Hickey and Doyle 1977, Wolfe and Upchurch 1987, Upchurch and Dilcher 1990) can provide insights into climate and vegetational structure that are unobtainable from mesofossils, the structure and size of flowers, fruits and seeds provides information on other aspects of ecology, including pollination and dispersal biology. Most importantly, however, the structure of flowers, fruits and seeds preserved as mesofossils usually provides a more robust basis for comparing fossil angiosperms with their living relatives than either leaves or dispersed pollen grains, thereby facilitating more detailed insights into patterns of early angiosperm systematic diversification.

The new palynological information from Torres Vedras, obtained from studies of stamens and pollen clumps isolated from the assemblage highlights the opportunities for integrating studies of mesofossil floras with palynological research. However, to be maximally useful for evolutionary studies high resolution scanning electron microscopy will be needed, either of grains picked from palynological residues (e.g. Walker and Walker 1984, 1986) or of grains seen in strew mounts on SEM stubs (Hughes et al. 1979, 1991, Ward 1986, Hughes and McDougall 1987, 1990, 1994, Penny 1991, Hughes 1994). Many of the key palynological features needed for comparative studies are too small to be seen with light microscopy.

Especially interesting for understanding Early Cretaceous vegetation will be information on the vegetative parts and pollen organs of the BEG group, because these plants were important in plant communities that included early angiosperms and this group also appear to have diversified dramatically at around the same time as angiosperms during the mid-Cretaceous (Crane and Lidgard 1989). The small seed size of the BEG-group suggests an ecological role similar to early angiosperms as early colonizers of disturbed environments (Crane and Upchurch 1987), although the larger embryo size in the BEG group compared to that of 
early angiosperms (Friis et al. 2015a, 2019c) is an interesting difference.

The BEG group is important because molecular phylogenetics of living plants suggests that extant Gnetales are closely related to extant conifers, and perhaps especially closely related to extant Pinaceae (Chaw et al. 2000, Ran et al. 2018). This raises fundamental questions about how the ovulate reproductive structures of the BEG group should be compared with each other, with those of conifers and with those of other seed plants. Similarly, while the pollen organs of the BEG group appear quite different, the close relationship indicated by their shared chlamydospermous seed structure suggests that their pollen organs should also share a common ground plan. Integration and harmonization of evidence from mesofossils (e.g. Erdtmanithecales; Friis and Pedersen 1996), with evidence from impression/ compressions (e.g. Crane and Upchurch 1987, Rydin et al. 2006) and permineralizations (Wieland 1906, Rothwell and Stockey 2002, Stockey and Rothwell 2003) will be important to address the diverse ecological and phylogenetic issues raised by the recognition of the BEG group.

Also critical for improved understanding of seed plant phylogenetics, and perhaps also angiosperm origins, will be new information on other extinct seed plants that are well represented in Early Cretaceous mesofossil floras from other regions. For example, new information on the ovule bearing structures of corystosperms from mesofossils floras (Shi et al. 2016) and also permineralized fossils (Rothwell and Stockey 2016) suggests new interpretations of homology (Shi et al. 2019). Similarly, information from mesofossil floras is expanding information on plants potentially related to extant Ginkgo (Herrera et al. 2017). There is much scope for future work of this kind.

Studies of mesofossil floras from the Mesozoic have already greatly advanced our understanding of the structure, relationships and biology of early angiosperms in Early Cretaceous vegetation. Mesofossils have also yielded valuable new perspectives for seed plant phylogenetics. Important for future progress will be the discovery of additional mesofossil floras with good preservation from the Late Jurassic and Early Cretaceous, especially in areas beyond western Europe and eastern North America. Research on these mesofossil floras, especially those from earlier sediments, will be important to provide additional direct evidence that confirms the presence or otherwise of early angiosperms, but also contributes new information on extinct seed plants that will help place the extant diversity of angiosperms into their appropriate evolutionary context.

\section{Acknowledgements}

We thank the Paul Scherrer Institut, Villigen, Switzerland for provision of synchrotron radiation beamtime at the TOMCAT beamline X02DA of the Swiss Light Source and Federica Marone for her help at the beamline. We are also grateful to Anna Lindström for help with the SRXTM analyses. We also thank Claus Konradsen for the permission to cite results from his unpublished Master thesis and Lavinia Trevisan for sharing unpublished information from the southern Tuscany region. Thanks are also due to Rihab
Yousif for help in curation of the Torres Vedras material. We are also grateful to Jiři Kvaček and Steven Manchester for constructive and helpful comments to the manuscript. Financial support was provided by the Swiss Light Source (projects 20080872, 20100167, 20110963, 20130185, 20141047, 20160140 and 20171476) and by the Swedish Research Council (Vetenskapsrådet 2014-5228 to E. M. Friis). We also thank the Oak Spring Garden Foundation for support during the preparation of this paper.

\section{References}

Balthazar, M. von, Crane, P. R., Pedersen, K. R., Friis, E. M. (2011): New flowers of Laurales from the Early Cretaceous (Early to Middle Albian) of eastern North America. - In: Wanntorp, L., Ronse De Craene, L. P. (eds), Flowers on the tree of life. Cambridge University Press, Cambridge, pp. 49-87. https://doi.org/10.1017/cbo9781139013321.003

Balthazar, M. von, Pedersen, K. R., Crane, P. R., Friis, E. M. (2008): Carpestella lacunata gen. et sp. nov., a new basal angiosperm flower from the Early Cretaceous (Early to Middle Albian) of eastern North America. - International Journal of Plant Sciences, 169: 890-898. https://doi.org/10.1086/589692

Balthazar, M. von, Pedersen, K. R., Crane, P. R., Stampanoni, M., Friis, E. M. (2007): Potomacanthus lobatus gen. et sp. nov., a new flower of probable Lauraceae from the Early Cretaceous (Early to Middle Albian) of eastern North America. - American Journal of Botany, 94: 2041-2053. https://doi.org/10.3732/ajb.94.12.2041

Balthazar, M. von, Pedersen, K. R., Friis, E. M. (2005): Teixeiraea lusitanica gen. et sp. nov., a ranunculalean flower from the Early Cretaceous of Portugal. - Plant Systematics and Evolution, 255: 55-75. https://doi.org/10.1007/s00606-005-0347-z

Banks, H., Stafford, P., Crane, P. R. (2007): Aperture variation in the pollen of Nelumbo (Nelumbonaceae). - Grana, 46: 157-162. https://doi.org/10.1080/00173130701485191

Batten, D. J. (1998): Palaeoenvironmental implication of plant, insect and other organic-walled microfossils in the Weald Clay Formation (Lower Cretaceous) of southeast England. - Cretaceous Research, 19: 279-315. https://doi.org/10.1006/cres.1998.0116

Batten, D. J. (2012): Taxonomic implications of exospore structure in selected Mesozoic lycopsid megaspores. Palynology, 36(s1): 144-160. https://doi.org/10.1080/01916122.2011.642122

Batten, D. J., Koppelhus, E. B. (1993): Morphological reassessment of some zonate and coronate megaspore genera of mainly post-Palaeozoic age. - Review of Palaeobotany and Palynology, 78: 19-40. https://doi.org/10.1016/0034-6667(93)90015-m

Batten, D. J., Kovach, W. L. (1990): Catalog of Mesozoic and Tertiary megaspores. - AASP Contributions Series, 24: 1-227.

Brenner, G. J. (1996): Evidence for the earliest stage of angiosperm pollen evolution: a paleoequatorial section from Israel. - In: Taylor, D. W., Hickey, L. J. (eds), Flowering 
plant origin, evolution and phylogeny. Chapman et Hall, New York, pp. 91-115.

https://doi.org/10.1007/978-0-585-23095-5_5

Brenner, G. J., Bickoff, I. S. (1992): Palynology and age of the Lower Cretaceous basal Kurnub Group from the coastal plain to the northern Negev of Israel. - Palynology, 16: 137-185.

Bykowska, J., Klimko, M. (2016): Pollen morphology in selected Cupressaceae Gray. and Sciadopityaceae Luerss. species in an experimental culture. - Steciana, 20: 7-14.

Chapman, J. L. (1986): Practical difficulties in the application of the species concept in Albian angiosperm pollen. - Special Papers in Palaeontology, 35: 41-53.

Chaw, S., Parkinson, C., Cheng, Y., Vincent, T., Palmer, J. (2000): Seed plant phylogeny inferred from all three plant genomes: Monophyly of extant gymnosperms and origin of Gnetales from conifers. - Proceedings of the National Academy of Sciences of the United States of America, 97: 4086-4091. https://doi.org/10.1073/pnas.97.8.4086

Coiro, M., Doyle, J. A., Hilton, J. (2019): How deep is the conflict between molecular and fossil evidence on the age of angiosperms? - New Phytologist, 223: 83-99. https://doi.org/10.1111/nph.15708

Cookson, I. C. (1947): Plant microfossils from the lignites of Kerguelen Archipelago. - B.A.N.Z. Antarctic Reserach Expedition (1929-1931), Series A, v. 2, Geology, pt. 8, pp. 129-142.

Corner, E. J. H. (1976): The seeds of dicotyledons. - Cambridge University Press, Cambridge, 320 pp.

Crandall-Stotler, B., Stotler, R. (2000): Morphology and classification of the Marchantiophyta. - In: Shaw, A. J., Goffinet, B. (eds), Bryophyte Biology. Cambridge University Press, Cambridge, pp. 21-70. https://doi.org/10.1017/cbo9781139171304.003

Crane, P. R., Friis, E. M., Pedersen, K. R. (1994): Paleobotanical evidence on the early radiation of magnoliid angiosperms. - Plant Systematics and Evolution, Supplement 8: 51-72. https://doi.org/10.1007/978-3-7091-6910-0_4

Crane, P. R., Lidgard, S. (1989): Angiosperm diversification and palaeolatitudinal gradients in Cretaceous floristic diversity. - Science, 246: 675-678.

https://doi.org/10.1126/science.246.4930.675

Crane, P. R., Lidgard, S. (1990): Angiosperm radiation and patterns of Cretaceous palynological diversity. - In: Taylor, P. D., Larwood, G. P. (eds), Evolutionary Radiations. Oxford University Press, Oxford, pp. 377-407.

Crane, P. R., Upchurch, G. R. (1987): Drewria potomacensis gen. et sp. nov., an Early Cretaceous member of Gnetales from the Potomac Group of Virginia. - American Journal of Botany, 74: 1722-1736. https://doi.org/10.1002/j.1537-2197.1987.tb08774.x

Cúneo, N. R., Hermsen, E. J., Gandolfo, M. A. (2013): Regnellidium (Salviniales, Marsileaceae). Macrofossils and associated spores from the Late Cretaceous of South America. - International Journal of Plant Sciences, 174: 340-349. https://doi.org/10.1086/668811

Dejax, J., Pons, D., Yans, J. (2007): Palynology of the dinosaur-bearing Wealden facies in the natural pit of Bernis- sart (Belgium). - Review of Palaeobotany and Palynology, 144: 25-38.

https://doi.org/10.1016/j.revpalbo.2005.10.004

Dettmann, M. E. (1963): Upper Mesozoic microfloras from southeastern Australia. - Proceedings of the Royal Society of Victoria, new series, 77: 1-148.

Dettmann, M. E., Clifford, H. T. (1992): Phylogeny and biogeography of Ruffordia, Mohria and Anemia (Schizaeaceae) and Ceratopteris (Pteridaceae): evidence from in situ and dispersed spores. - Alcheringa, 16: 269-314. https://doi.org/10.1080/03115519208619111

Dijkstra, S. J. (1949): Megaspores and some other fossils from the Aachenian (Senonian) in south Limburg, Netherlands. - Mededeelingen van de geologische Stichting, Nieuwe Serie, 3: 19-32.

Dijkstra, S. J. (1951): Wealden megaspores and their stratigraphic value. - Mededelingen van de Geologische Stichting, Nieuwe Serie, 5: 7-21.

Dilcher, D. L., Crane, P. R. (1984): Archaeanthus: an early angiosperm from the Cenomanian of the Western Interior of North America. - Annals of the Missouri Botanical Garden, 71: 351-383. https://doi.org/10.2307/2399030

Dinis, J. L. (1999): Estratigraphia e sedimentologia da formação de Figueira da Foz. Aptiano a Cenomaniano do sector norte da Bacia Lusitânica [Stratigraphy and sedimentology of the Figueira da Foz Formation. Aptian to Cenomanian of north sector from the Lusitanian Basin]; Ph.D. thesis - MS, University of Coimbra, Coimbra, Portugal, 381 pp. (in Portugese) (copy in personal library of E. M. Friis)

Dinis, J. L. (2001): Definição da Formação da Figueira da Foz - Aptiano a Cenomaniano do sector central da margem oeste Ibérica [Definition of the Figueira da Foz Formation - Aptian to Cenomanian of the central sector of the western Iberian margin]. - Comunicações do Instituto Geológico e Mineiro, 88: 127-160. (in Portugese)

Dinis, J. L., Oliveira, F. P., Rey, J., Duarte, I. L. (2010): Finding geological heritage: Legal issues on private property and fieldwork. The Case of outstanding Early angiosperms (Barremian to Albian, Portugal). - Geoheritage, 2: 77-90. https://doi.org/10.1007/s12371-010-0013-x

Dinis, J. L., Rey, J., Cunha, P. P., Callapez, P., Pena Dos Reis, R. (2008): Stratigraphy and allogenic controls of the western Portugal Cretaceous: an updated synthesis. Cretaceous Research, 29: 772-780. https://doi.org/10.1016/j.cretres.2008.05.027

Dinis, J. L., Rey, J., Graciansky, P.-C. D. (2002): Le bassin lusitanien (Portugal) à l'Aptien supérieur-Albien: organisation séquentielle, proposition de corrélations, évolution. - Comptes Rendus Geoscience, 334: 757-764. https://doi.org/10.1016/s1631-0713(02)01815-1

Dino, R., Pocknall, D. T., Dettmann, M. E. (1999): Morphology and ultrastructure of elater-bearing pollen from the Albian to Cenomanian of Brazil and Equador: implications for botanical affinity. - Review of Palaeobotany and Palynology, 105: 201-235. https://doi.org/10.1016/s0034-6667(98)00076-1

Doyle, J. A., Endress, P. K. (2014): Integrating Early Cretaceous fossils into the phylogeny of living angiosperms: 
ANITA lines and relatives of Chloranthaceae. - International Journal of Plant Sciences, 175: 555-600.

https://doi.org/10.1086/675935

Doyle, J. A., Hickey, L. J. (1976): Pollen and leaves from the mid-Cretaceous Potomac Group and their bearing on early angiosperm evolution. - In: Beck, C. B. (eds), Origin and Early Evolution of Angiosperms. Columbia University Press, New York, pp. 139-206.

Doyle, J. A., Hotton, C. L. (1991): Diversification of early angiosperm pollen in a cladistic context. - In: Blackmore, S., Barnes, S. H. (eds), Pollen and Spores, Patterns of Diversity. Clarendon Press, Oxford, pp. 169-195.

Ellis, C. H., Tschudy, R. H. (1964): The Cretaceous megaspore genus Arcellites Miner. - Micropaleontology, 10: 73-79.

https://doi.org/10.2307/1484626

Eriksson, O., Friis, E. M., Pedersen, K. R., Crane, P. R. (2000): Seed size and dispersal systems of Early Cretaceous angiosperms from Famalicão, Portugal. - International Journal of Plant Sciences, 161: 319-329.

https://doi.org/10.1086/314248

Friis, E. M. (1983): Upper Cretaceous (Senonian) floral structures of juglandalean affinity containing Normapolles pollen. - Review of Palaeobotany and Palynology, 39: $161-188$.

https://doi.org/10.1016/0034-6667(83)90015-5

Friis, E. M. (1984): Preliminary report on Upper Cretaceous angiosperm reproductive organs from Sweden and their level of organization. - Annals of the Missouri Botanical Garden, 71: 403-418.

https://doi.org/10.2307/2399032

Friis, E. M. (1985): Structure and function in Late Cretaceous angiosperm flowers. - Biologiske Skrifter, Det Kongelige Danske Videnskabernes Selskab, 25: 1-37.

Friis, E. M., Crane, P. R., Pedersen, K. R. (1997): Anacostia, a new basal angiosperm from the Early Cretaceous of North America and Portugal with trichotomocolpate/ monocolpate pollen. - Grana, 36: 225-244. https://doi.org/10.1080/00173139709362611

Friis, E. M., Crane, P. R., Pedersen, K. R. (2011): Early flowers and angiosperm evolution. - Cambridge University Press, Cambridge, $\mathrm{x}+585 \mathrm{pp}$.

Friis, E. M., Crane, P. R., Pedersen, K. R. (2017): Saportanthus, an extinct genus of Laurales from the Early Cretaceous of Portugal. - International Journal of Plant Sciences, 78: 650-672. https://doi.org/10.1086/693108

Friis, E. M., Crane, P. R., Pedersen, K. R. (2018a): Tanispermum, a new genus of distinctive hemi-orthotropous to hemi-anatropous angiosperm seeds from the Early Cretaceous of eastern North America. - American Journal of Botany, 105: 1369-1388. https://doi.org/10.1002/ajb2.1124

Friis, E. M., Crane, P. R., Pedersen, K. R. (2018b): Extinct taxa of exotestal seeds close to Austrobaileyales and Nymphaeales from the Early Cretaceous of Portugal. Fossil Imprint, 74(1-2): 135-158. https://doi.org/10.2478/if-2018-0010

Friis, E. M., Crane, P. R., Pedersen, K. R. (2018c): Rightcania and Kvacekispermum: Early Cretaceous seeds from eastern North America and Portugal provide further evi- dence of the early chloranthoid diversification. - Fossil Imprint, 74(1-2): 65-76.

https://doi.org/10.2478/if-2018-0006

Friis, E. M., Crane, P. R., Pedersen, K. R. (2018d): Fossil seeds with affinities to Austrobaileyales and Nymphaeales from the Early Cretaceous (early-middle Albian) of Virginia and Maryland, U.S.A: new evidence for extensive extinction near the base of the angiosperm tree. - In: Krings, M., Harper, C. J., Cúneo, N. R., Rothwell, G. W. (eds), Transformative Paleobotany: Papers to Commemorate the Life and Legacy of Thomas N. Taylor. Academic Press, London, pp. 417-435.

https://doi.org/10.1016/b978-0-12-813012-4.00017-6

Friis, E. M., Crane, P. R., Pedersen, K. R. (2019a): Extinct diversity among Early Cretaceous angiosperms: mesofossil evidence of early Magnoliales from Portugal. International Journal of Plant Sciences, 180: 93-127. https://doi.org/10.1086/701319

Friis, E. M., Crane, P. R., Pedersen, K. R. (2019b): Hedyosmum-like fossils in the Early Cretaceous diversification of angiosperms. - International Journal of Plant Sciences, 180: 232-239. https://doi.org/10.1086/701819

Friis, E. M., Crane, P. R., Pedersen, K. R. (2019c): Chlamydospermous seeds document the diversity and abundance of extinct gnetalean relatives in Early Cretaceous vegetation. - International Journal of Plant Sciences, 180(7): 643-666. https://doi.org/10.1086/704356

Friis, E. M., Crane, P. R., Pedersen, K. R., Stampanoni, M., Marone, F. (2015a): Exceptional preservation of tiny embryos documents seed dormancy in early angiosperms. Nature, 528: 551-554. https://doi.org/10.1038/nature16441

Friis, E. M., Eklund, H., Pedersen, K. R., Crane, P. R. (1994a): Virginianthus calycanthoides gen. et sp. nov. A calycanthaceous flower from the Potomac Group (Early Cretaceous) of eastern North America. - International Journal of Plant Sciences, 155: 772-785. https://doi.org/10.1086/297217

Friis, E. M., Grimm, G. W., Mendes, M. M., Pedersen, K. R. (2015b): Canrightiopsis, a new Early Cretaceous fossil with Clavatipollenites-type pollen bridge the gap between extinct Canrightia and extant Chloranthaceae. Grana, 54: 184-212. https://doi.org/10.1080/00173134.2015.1060750

Friis, E. M., Marone, F., Pedersen, K. R., Crane, P. R., Stampanoni, M. (2014a): Three-dimensional visualization of fossil flowers, fruits, seeds and other plant remains using synchrotron radiation X-ray tomographic microscopy (SRXTM): New insights into Cretaceous plant diversity. - Journal of Paleontology, 88: 684-701. https://doi.org/10.1666/13-099

Friis, E. M., Mendes, M. M., Pedersen, K. R. (2018e): Paisia, an Early Cretaceous eudicot angiosperm flower with pantoporate pollen from Portugal. - Grana, 57: 1-15. https://doi.org/10.1080/00173134.2017.1310292

Friis, E. M., Pedersen, K. R. (1990): Structure of the Lower Cretaceous fern Onychiopsis psilotoides from Bornholm, Denmark. - Review of Palaeobotany and Palynology, 66: 47-63.

https://doi.org/10.1016/0034-6667(90)90028-h 
Friis, E. M., Pedersen, K. R. (1996): Eucommiitheca, a new pollen organ with Eucommiidites pollen from the Early Cretaceous of Portugal. - Grana, 35: 104-112. https://doi.org/10.1080/00173139609429480

Friis, E. M., Pedersen, K. R. (2011): Canrightia resinifera gen. et sp. nov., a new extinct angiosperm with Retimonocolpites-type pollen from the Early Cretaceous of Portugal: missing link in the eumagnoliid tree? - Grana, 50: 3-29.

https://doi.org/10.1080/00173134.2011.559728

Friis, E. M., Pedersen, K. R., Crane, P. R. (1994b): Angiosperm floral structures from the Early Cretaceous of Portugal. - Plant Systematics and Evolution Supplement, 8: 31-49.

https://doi.org/10.1007/978-3-7091-6910-0_3

Friis, E. M., Pedersen, K. R., Crane, P. R. (1995): Appomattoxia ancistrophora gen. et sp. nov., a new Early Cretaceous plant with similarities to Circaeaster and extant Magnoliidae. - American Journal of Botany, 82: 933-943. https://doi.org/10.1002/j.1537-2197.1995.tb15710.x

Friis, E. M., Pedersen, K. R., Crane, P. R. (1999): Early angiosperm diversification: the diversity of pollen associated with angiosperm reproductive structures in Early Cretaceous floras from Portugal. - Annals of the Missouri Botanical Garden, 86: 259-296. https://doi.org/10.2307/2666179

Friis, E. M., Pedersen, K. R., Crane, P. R. (2000a): Reproductive structure and organization of basal angiosperms from the Early Cretaceous (Barremian or Aptian) of Western Portugal. - International Journal of Plant Sciences, 161(6, suppl.): S169-S182. https://doi.org/10.1086/317570

Friis, E. M., Pedersen, K. R., Crane, P. R. (2000b): Fossil floral structures of a basal angiosperm with monocolpate, reticulate-acolumellate pollen from the Early Cretaceous of Portugal. - Grana, 39: 226-239. https://doi.org/10.1080/00173130052017262

Friis, E. M., Pedersen, K. R., Crane, P. R. (2004): Araceae from the Early Cretaceous of Portugal: Evidence on the emergence of monocotyledons. - Proceedings of the National Academy of Sciences of the United States of America, 101: 16 565-16 570.

https://doi.org/10.1073/pnas.0407174101

Friis, E. M., Pedersen, K. R., Crane, P. R. (2006): Cretaceous angiosperm flowers: Innovation and evolution in plant reproduction. - Palaeogeography, Palaeoclimatology, Palaeoecology, 232: 251-293.

https://doi.org/10.1016/j.palaeo.2005.07.006

Friis, E. M., Pedersen, K. R., Crane, P. R. (2009): Early Cretaceous mesofossils from Portugal and eastern North America related to the Bennettitales-Erdtmanithecales-Gnetales group. - American Journal of Botany, 96: 252-283. https://doi.org/10.3732/ajb.0800113

Friis, E. M., Pedersen, K. R., Crane, P. R. (2010a): Cretaceous diversification of angiosperms in the western part of the Iberian Peninsula. - Review of Palaeobotany and Palynology, 162: 341-361. https://doi.org/10.1016/j.revpalbo.2009.11.009

Friis, E. M., Pedersen, K. R., Crane, P. R. (2010b): Diversity in obscurity: fossil flowers and the early history of angiosperms. - Philosophical Transactions of the Royal Society of London, B, 365: 369-382.

https://doi.org/10.1098/rstb.2009.0227

Friis, E. M., Pedersen, K. R., Crane, P. R. (2013): New diversity among chlamydospermous seeds from the Early Cretaceous of Portugal and North America. - International Journal of Plant Sciences, 174: 530-558. https://doi.org/10.1086/668250

Friis, E. M., Pedersen, K. R., Crane, P. R. (2016): Kenilanthus, a new eudicot flower with tricolpate pollen from the Early Cretaceous (early-middle Albian) of eastern North America. - Grana, 56: 161-173. https://doi.org/10.1080/00173134.2016.1158863

Friis, E. M., Pedersen, K. R., Marone, F. (2014b): Arcellites punctatus sp. nov.: a new megaspore from the Early Cretaceous of Portugal studied using high resolution synchrotron radiation $\mathrm{x}$-ray tomographic microscopy (SRXTM). - Grana, 53: 91-102. https://doi.org/10.1080/00173134.2014.910547

Friis, E. M., Skarby, A. (1981): Structurally preserved angiosperm flowers from the Upper Cretaceous of southern Sweden. - Nature, 291: 485-486. https://doi.org/10.1038/291484a0

Gale, A. S. (2000): The Cretaceous World. - In: Culver, S. J., Rawson, P. R. (eds), Biotic response to Global Change. Cambridge University Press, Cambridge, pp. 4-19.

Góczán, F., Juhász, M. (1984): Monosulcate pollen grains of angiosperms from Hungarian Albian sediments I. - Acta Botanica Hungarica, 30: 289-319.

Golovneva, L., Alekseev, P., Bugdaeva, E., Volynets, E. (2018): An angiosperm dominated herbaceous community from the early - middle Albian of Primorye, Far East of Russia. - Fossil Imprint, 74(1-2): 165-178. https://doi.org/10.2478/if-2018-0012

Gonzáles, F., Rudall, P. J., Furness, C. A. (2001): Microsporogenesis and systematics of Aristolochiaceae. - Botanical Journal of the Linnean Society, 137: 221-242. https://doi.org/10.1006/boj1.2001.0478

Grayum, M. H. (1992): Comparative external pollen ultrastructure of the Araceae and putative related taxa. Monographs in Systematic Botany from the Missouri Botanical Garden, 43: 1-167.

Grímsson, F., Grimm, G. W., Zetter, R. (2017): Tiny pollen grains: first evidence of Saururaceae from the Late Cretaceous of western North America. - PeerJ, 5: e3434 (25 pp.). https://doi.org/10.7717/peerj.3434

Grímsson, F., Zetter, R., Halbritter, H., Grimm, G. W. (2014): Aponogeton pollen from the Cretaceous and Paleogene of North America and West Greenland: Implications for the origin and palaeobiogeography of the genus. - Review of Palaeobotany and Palynology, 200: 116-187. https://doi.org/10.1016/j.revpalbo.2013.09.005

Groot, J. J., Groot, C. R. (1962): Plant microfossils from Aptian, Albian and Cenomanian deposits of Portugal. Comunicações dos Serviços Geológicos de Portugal, 46: 133-176.

Halbritter, H., Buchner, R. (2016): Peperomia polybotrya.In: PalDat - A palynological database. https://www.paldat.org/pub/Peperomia_polybotrya/302675 
Hall, J. W. (1963): Megaspores and other fossils in the Dakota Formation (Cenomanian) of Iowa, (U.S.A.). - Pollen et Spores, 5: 425-443.

Harris, T. M. (1974): Williamsoniella lignieri: its pollen and the compression of spherical pollen grains. - Palaeontology, 17: 125-148.

Harris, E. B., Arens, N. C. (2016): A mid-Cretaceous angiosperm-dominated macroflora from the Cedar Mountain Formation of Utah, USA. - Journal of Paleontology, 90: 640-662. https://doi.org/10.1017/jpa.2016.44

Hedlund, R. W., Norris, G. (1968): Spores and pollen grains from Fredericksburgian (Albian) strata, Marshall County, Oklahoma. - Pollen et Spores, 10: 129-159.

Heer, O. (1881): Contributions à la flore fossile du Portugal. - Academie Royale des sciences, Lisbon, 51pp. +28 pls. https://doi.org/10.5962/bhl.title.78053

Heimhofer, U. (2004): Response of terrestrial palaeoenvironments to past changes in climate and carbon-cycling: Insights from palynology and stable isotope geochemistry; Doctoral thesis. - MS, ETH Zurich, Zurich, Switzerland, 166 pp. (available on-line, DISS ETH No. 15463) https://doi.org/10.3929/ethz-a-004741183

Heimhofer, U., Hochuli, P. A., Burla, S., Weissert, H. (2007): New records of Early Cretaceous angiosperm pollen from Portuguese coastal deposits: Implications for the timing of the early angiosperm radiation. - Review of Palaeobotany and Palynology, 144: 39-76.

https://doi.org/10.1016/j.revpalbo.2005.09.006

Hemsley, A., Collinson, M. E. (2008): Colloidal crystal-like structure of sporopollenin in the megaspore walls of Recent Selaginella and similar fossil spores. - Botanical Journal of the Linnean Society, 108: 307-320. https://doi.org/10.1111/j.1095-8339.1992.tb00247.x

Herendeen, P. S., Doyle, J. A., Endress, P. K., Takahashi, M. (2016): Cecilanthus polymerus, a novel multiparted flower from the mid-Cretaceous Rocky Point locality, Maryland. - Botany, 94: 787-803. https://doi.org/10.1139/cjb-2016-0039

Herendeen, P. S., Friis, E. M., Pedersen, K. R., Crane, P. R. (2017): Palaeobotanical redux: revisiting the age of the angiosperms. - Nature Plants, 3(3): 17015 (8 pp.).

https://doi.org/10.1038/nplants.2017.15

Hernandez-Castillo, G. R., Stockey, R. A., Rothwell, G. W. (2006): Anemia quatsinoensis sp. nov. (Schizaeaceae), a permineralized fern from the Lower Cretaceous of Vancouver Island. - International Journal of Plant Sciences, 67: 665-674.

https://doi.org/10.1086/502801

Herngreen, G. F. W., Kedves, M., Rovnina, L. V., Smirnova, S. B. (1996): Cretaceous palynofloral provinces: a review. - In: Jansonius, J., McGregor, D. C. (eds), Palynology: principles and applications. American Association of Stratigraphic Palynologists Foundation, Salt Lake City, pp. 1157-1188.

Herrera, F., Shi, G., Ichinnorov, N., Takahashi, M., Bugdaeva, E. V., Herendeen, P. S., Crane, P. R. (2017): The presumed ginkgophyte Umaltolepis has seed-bearing structures resembling those of Peltaspermales and Umkomasiales. - Proceedings of the National Academy of Sciences of the United States of America, 114(12): E2385-E2391.

https://doi.org/10.1073/pnas.1621409114

Hickey, L. J., Doyle, J. A. (1977): Early Cretaceous fossil evidence for angiosperm evolution. - The Botanical Review, 43: 2-104.

https://doi.org/10.1007/bf02860849

Hill, C. R. (1990): Ultrastructure of in situ fossil cycad pollen from the English Jurassic, with a description of the male cone Androstrobus balmei sp. nov. - Review of Palaeobotany and Palynology, 65: 165-173. https://doi.org/10.1016/0034-6667(90)90067-s

Horikx, M., Hochuli, P. A., Feist-Burkhardt, S., Heimhofer, U. (2016): Albian angiosperm pollen from shallow marine strata in the Lusitanian Basin, Portugal. - Review of Palaeobotany and Palynology, 228: 67-92. https://doi.org/10.1016/j.revpalbo.2015.12.008

Hueber, F. M. (1982): Megaspores and a palynomorph from the Lower Potomac Group in Virginia. - Smithsonian Contributions to Paleobiology, 49: 1-69. https://doi.org/10.5479/si.00810266.49.1

Hughes, N. F. (1976): Palaeobiology of angiosperm origins. - Cambridge University Press, Cambridge, 242 pp.

Hughes, N. F. (1994): The enigma of angiosperm origins. Cambridge University Press, Cambridge, 303 pp.

Hughes, N. F., Drewry, G., Laing, J. F. (1979): Barremian earliest angiosperm pollen. - Palaeontology, 22: 513-536.

Hughes, N. F., McDougall, A. B. (1987): Records of angiospermid pollen entry into the English Early Cretaceous succession. - Review of Palaeobotany and Palynology, 50: 255-272. https://doi.org/10.1016/0034-6667(87)90003-0

Hughes, N. F., McDougall, A. B. (1990): Barremian-Aptian angiospermid pollen records from southern England. Review of Palaeobotany and Palynology, 65: 145-151. https://doi.org/10.1016/0034-6667(90)90065-Q

Hughes, N. F., McDougall, A. B. (1994): Search for antecedents of Early Cretaceous monosulcate columellate pollen. - Review of Palaeobotany and Palynology, 83: 175-183. https://doi.org/10.1016/0034-6667(94)90067-1

Hughes, N. F., McDougall, A. B., Chapman, J. L. (1991): Exceptional new record of Cretaceous Hauterivian angiospermid pollen from southern England. - Journal of Micropalaeontology, 10: 75-82. https://doi.org/10.1144/jm.10.1.75

Ibrahim, M. I. A. (2002): New angiosperm pollen from the Upper Barremian-Aptian of the Western Desert, Egypt. - Palynology, 26: 107-133. https://doi.org/10.2113/0260107

Ibrahim, M. I. A., Zobaa, M. K., El-Noamani, Z. M., Tahoun, S. S. (2015): A review of the angiosperm pollen genus Cretacaeiporites Herngreen, with one new species from the Upper Cretaceous of Egypt. - Palynology, 41: 101-116. https://doi.org/10.1080/01916122.2015.1093561

Juhász, M., Góczán, F. (1985): Comparative study of Albian monosulcate angiosperm pollen grains. - Acta Biologica Szegediensis, 31: 147-172.

Konradsen, C. (1996): Nedre Kridt palynologi i Portugal [Lower Cretaceous palynology of Portuga]; PhD Thesis. 
- MS, University of Aarhus, Aarhus, Denmark. (in Danish) (copy in personal library of K. R. Pedersen)

Koppelhus, E. B., Batten, D. J. (1989): Late Cretaceous megaspores from southern Sweden: Morphology and palaeoenvironmental significance. - Palynology, 13: 91-120. https://doi.org/10.1080/01916122.1989.9989357

Koppelhus, E. B., Batten, D. J. (1992): Megaspore assemblages from the Jurassic and lowermost Cretaceous of Bornholm, Denmark. - Danmarks Geologiske Undersøgelse, Serie A, 32: 1-81.

Korszun, S., Klimko, M. (2014): Microsporangia and pollen morphology of Ginkgo biloba cultivars. - Dendrobiology, 71: 83-92.

Kramer, K. U. (1990): Schizaeaceae. - In: Kramer, K. U., Green, P. S. (eds), The families and genera of vascular plants. Vol. I: Pteridophytes and gymnosperms. Springer-Verlag, Berlin, Heidelberg, pp. 258-263. https://doi.org/10.1007/978-3-662-02604-5 44

Krassilov, V. A., Volynets, Y. (2008): Weedy Albian angiosperms. - Acta Palaeobotanica, 48: 151-169.

Kreunen, S. S., Osborn, J. M. (1999): Pollen and anther development in Nelumbo (Nelumbonaceae). - American Journal of Botany, 86: 1662-1676. https://doi.org/10.2307/2656664

Kvaček, J., Barrón, E., Heřmanová, Z., Mendes, M. M., Karch, J., Žemlička, J., Dudák, J. (2018): Araucarian conifer from late Albian amber of northern Spain. Papers in Palaeontology, 4: 643-656. https://doi.org/10.1002/spp2.1223

Kvaček, J., Doyle, J. A., Endress, P. E., Daviero-Gomez, V., Gomez, B., Tekleva, M. (2016): Pseudoasterophyllites cretaceus from the Cenomanian (Cretaceous) of the Czech Republic: A possible link between Chloranthaceae and Ceratophyllum. - Taxon, 65: 1345-1373. https://doi.org/10.12705/656.8

Leng, Q., Friis, E. M. (2003): Sinocarpus decussatus gen. et sp. nov, a new angiosperm with syncarpous fruits from the Yixian Formation of Northeast China. - Plant Systematics and Evolution, 241: 77-88. https://doi.org/10.1007/s00606-003-0028-8

Lidgard, S., Crane, P. R. (1988): Quantitative analyses of the early angiosperm radiation. - Nature, 331: 344-346. https://doi.org/10.1038/331344a0

Lidgard, S., Crane, P. R. (1990): Angiosperm diversification and Cretaceous floristic trends: a comparison of palynofloras and leaf macrofloras. - Paleobiology, 16: 77-93. https://doi.org/10.1017/s009483730000974x

Llorens, M., Perez Loinaze, V. S. (2015): Late Aptian angiosperm pollen grains from Patagonia: Earliest steps in flowering plant evolution at middle latitudes in southern South America. - Cretaceous Research, 57: 66-78. https://doi.org/10.1016/j.cretres.2015.07.019

Lupia, R. (1995): Paleobotanical data from fossil charcoal: An actualistic study of seed plant reproductive structures. - Palaios, 10: 465-477. https://doi.org/10.2307/3515048

Lupia, R. (2004): Megaspores and palynomorphs from the Lower Potomac Group of Maryland, U.S.A. - International Journal of Plant Sciences, 165: 651-670.

https://doi.org/10.1086/383332
Lupia, R., Schneider, H., Moeser, G. M., Pryer, K. M., Crane, P. R. (2000): Marsileaceae sporocarps and spores from the Late Cretaceous of Georgia, U.S.A. - International Journal of Plant Sciences, 161: 975-988. https://doi.org/10.1086/317567

Mädler, K. (1954): Azolla aus dem Quartär und Tertiär, sowie ihre Bedeutung für die Taxonomie älterer Sporen. Geologisches Jahrbuch, 70: 143-158.

Marcinkiewicz, T. (1978): Zespoły megasporowe w kajprze Polski [Megaspore associations of the Polish Cretaceous]. - Prace Instytutu Geologicznego, 87: 61-84. (in Polish)

McCohana, M. (1941): Ventral structures effecting capillarity in the Marchantiales. - American Journal of Botany, 28: 301-306.

https://doi.org/10.2307/2436787

Mendes, M. M., Barrón, E., Dinis, P., Rey, J., Batten, D. J. (2018): A new palynoflora from upper Barremian-lower Aptian rocks at Casal do Borracho, Torres Vedras, western Portugal, and its palaeoecological significance. - Cretaceous Research, 90: 363-374. https://doi.org/10.1016/j.cretres.2018.06.012

Mendes, M. M., Dinis, J., Pais, J., Friis, E. M. (2011): Early Cretaceous flora from Vale Painho (Lusitanian Basin, western Portugal): an integrated palynological and mesofossil study. - Review of Palaeobotany and Palynology, 166: 152-162. https://doi.org/10.1016/j.revpalbo.2011.04.003

Mendes, M. M., Dinis, J., Pais, J., Friis, E. M. (2014): Vegetational composition of the Early Cretaceous Chicalhão flora (Lusitanian Basin, western Portugal) based on palynological and mesofossil assemblages. - Review of Palaeobotany and Palynology, 200: 65-81. https://doi.org/10.1016/j.revpalbo.2013.08.003

Mendes, M. M., Friis, E. M. (2018): The Nossa Senhora da Luz flora from the Early Cretaceous (early Aptian-late Albian) of Juncal in the western Portuguese Basin. Acta Palaeobotanica, 58: 159-174. https://doi.org/10.2478/acpa-2018-0015

Muller, J. (1970): Palynological evidence on early differentiation of angiosperms. - Biological Reviews, 45: 417-450. https://doi.org/10.1111/j.1469-185x.1970.tb01649.x

Neumann, V. H., Borrego, A. G., Cabrera, L., Dino, R. (2003): Organic matter composition and distribution through the Aptian-Albian lacustrine sequences of the Araripe Basin, northeastern Brazil. - International Journal of Coal Geology, 54: 21-40. https://doi.org/10.1016/s0166-5162(03)00018-1

Nowak, M. D., Lupia, R. (2004): Arcellites stellatus new species, a new megaspore from the Lower Cretaceous of Maryland, USA. - Journal of Paleontology, 78: 1207-1213. https://doi.org/10.1666/0022-3360(2004)078<1207:asnsan $>2.0 . \operatorname{co} ; 2$

Nye, E., Feist-Burkhardt, S., Horne, D. J., Ross, A. J., Whittaker, J. E. (2008): The palaeoenvironment associated with a partial Iguanodon skeleton from the Upper Weald Clay (Barremian, Early Cretaceous) at Smokejacks Brickworks (Ockley, Surrey, UK), based on palynomorphs and ostracods. - Cretaceous Research, 29: 417-444.

https://doi.org/10.1016/j.cretres.2008.01.004 
Pacltová, B., Lashin, G. M. A. (1999): Characteristic sporomorphs of the Elaterates province in the Cenomanian of Bohemia (Central Europe) - comparison with the mid-Cretaceous of Egypt (northeastern Africa). - Acta Palaeobotanica, Suppl. 2: 159-165.

Pais, J., Reyre, Y. (1981): Problèmes posés par la population sporo-pollinique d'un niveau à plantes de la série de Buarcos (Portugal). - Boletim da Sociedade Geológica de Portugal, 22: 35-40.

Pedersen, K. R., von Balthazar, M., Crane, P. R., Friis, E. M. (2007): Early Cretaceous floral structures and in situ tricolpate-striate pollen: New early eudicots from Portugal. - Grana, 46: 176-196.

https://doi.org/10.1080/00173130701526507

Pedersen, K. R., Crane, P. R., Friis, E. M. (1989): Pollen organs and seeds with Eucommiidites pollen. - Grana, 28: 279-294. https://doi.org/10.1080/00173138909427441

Penny, J. H. J. (1986): An Early Cretaceous angiosperm pollen assemblage from Egypt. - Special Papers in Palaeontology, 35: 121-134.

Penny, J. H. J. (1988a): Early Cretaceous striate tricolpate pollen from the Borehole Mersa Matruh 1, North West Desert, Egypt. - Journal of Micropalaeontology, 7: 201-215. https://doi.org/10.1144/jm.7.2.201

Penny, J. H. J. (1988b): Early Cretaceous acolumellate semitectate pollen from Egypt. - Palaeontology, 31: 373-418.

Penny, J. H. J. (1989): New Early Cretaceous forms of the angiosperm pollen genus Afropollis from England and Egypt. - Review of Palaeobotany and Palynology, 58: 289-299.

https://doi.org/10.1016/0034-6667(89)90089-4

Penny, J. H. J. (1991): Early Cretaceous angiosperm pollen from the borehole Mersa Matruh 1, North West Desert, Egypt. - Palaeontographica, B, 222: 31-88.

Pierce, R. L. (1961): Lower Upper Cretaceous plant microfossils from Minnesota. - Minnesota Geological Survey Bulletin, 42: 1-86.

Potonié, R. (1956): Synopsis der Gattungen der Sporae dispersae. I. Sporites. - Beihefte zum Geologischen Jahrbuch, 23: 1-103.

Punt, W., Hoen, P. P., Blackmore, S., Nilsson, S., Le Thomas, A. (2007): Glossary of pollen and spore terminology. - Review of Palaeobotany and Palynology, 143:1-81. https://doi.org/10.1016/j.revpalbo.2006.06.008

Raine, J. I., Mildenhall, D. C., Kennedy, E. M. (2011): New Zealand fossil spores and pollen: an illustrated catalogue. $-2^{\text {nd }}$ ed GNS Science miscellaneous series no 4. http://data.gns.cri.nz/sporepollen/index.htm

Ran, J.-H., Shen, T.-T., Wang, M.-M., Wang, X.-Q. (2018): Phylogenomics resolves the deep phylogeny of seed plants and indicates partial convergent or homoplastic evolution between Gnetales and angiosperms. - Proceedings of the Royal Society, B, 285: 20181012 (9 pp.). https://doi.org/10.1098/rspb.2018.1012

Regali, M. S. P. (1989): Tucanopollis, um gênero novo das angiospermas primitivas [Tucanopollis, a new genus of primitive angiosperms]. - Boletim de Geociências da Petrobrás, 3: 395-402. (in Portugese)

Regali, M. S. P., Uesugui, N., Santos, A. S. (1974): Palinologia dos sedimentos meso-cenozóicos do Brasil [Palyno- logy of Meso-Cenozoic sediments from Brazil]. - Boletim Técnico da Petrobrás, 17: 117-191. (in Portugese)

Renéville, P. D., Raynaud, J.-F. (1981): Palynologie du stratotype du Barrémien. - Bulletin du Centre de recherches Elf Exploration Production, 5: 1-29.

Rey, J. (1972): Recherches géologiques sur le Crétacé inférieur de l'Estremadura (Portugal). - Serviços Geológicos de Portugal, Memórias (Nova Série) 3, 21: 1-477.

Rey, J. (1993): Les unités lithostratigraphiques du groupe de Torres Vedras (Estremadura, Portugal). - Comunicações Instituto Geológico e Mineiro, 79: 75-85.

Rey, J., Dinis, J. L., Callapez, P., Cunha, P. P. (2006): Da rotura continental à margem passiva. Composição e evolução do Cretácico de Portugal [From continental breakup to passive margin. The Cretaceous record and evolution of Portugal]. - Ministério da Economia e da Inovação, Lisboa, 75 pp. (in Portugese with English abstract)

Rothwell, G. W., Stockey, R. A. (2002): Anatomically preserved Cycadeoidea (Cycadeoidaceae), with a reevaluation of systematic characters for the seed cones of Bennettitales. - American Journal of Botany, 89: 1447-1458. https://doi.org/10.3732/ajb.89.9.1447

Rothwell, G. W., Stockey, R. A. (2016): Phylogenetic diversification of Early Cretaceous seed plants: The compound seed cone of Doylea tetrahedrasperma. American Journal of Botany, 103: 923-937. https://doi.org/10.3732/ajb.1600030

Ruffell, A. H., Batten, D. J. (1990): The Barremian-Aptian arid phase in western Europe. - Palaeogeography, Palaeoclimatology, Palaeoecology, 80: 197-212. https://doi.org/10.1016/0031-0182(90)90132-q

Rydin, C., Pedersen, K. R., Crane, P. R., Friis, E.M. (2006): Former diversity of Ephedra (Gnetales): evidence from Early Cretaceous seeds from Portugal and North America. - Annals of Botany, 98: 123-140. https://doi.org/10.1093/aob/mcl078

Saporta, G. D. (1894): Flore fossile du Portugal. Nouvelles contributions à la flore Mésozoique. Accompagnées d'une notice stratigraphique par Paul Choffat. - Imprimerie de l'Academie Royale des Sciences, Lisbon, 288 pp. +39 pls.

Schemel, M. P. (1950): Cretaceous plant microfossils from Iowa. - American Journal of Botany, 37: 750-754. https://doi.org/10.1002/j.1537-2197.1950.tb11066.x

Schmid, R. (1986): On Cornerian and other terminology of angiospermous and gymnospermous seed coats: Historical perspective and terminological recommendations. Taxon, 35: 476-491. https://doi.org/10.2307/1221901

Schrank, E. (2017): Palynology of the Albian Makhtesh Qatan site, northern Negev (Israel), with descriptions of two new pollen species. - Review of Palaeobotany and Palynology, 246: 185-215. https://doi.org/10.1016/j.revpalbo.2017.06.007

Schrank, E., Mahmoud, M. S. (2002): Barremian angiosperm pollen and associated palynomorphs from the Dakhla Oasis area, Egypt. - Palaeontology, 45: 33-56. https://doi.org/10.1111/1475-4983.00226

Scott, A. C., Collinson, M. E., Cripps, J., Nichols, G. J., Featherstone, C. (1999): Charcoal-rich plant debris accumulations in the Lower Cretaceous of the Isle of Wight, England. - Acta Palaeobotanica, 2(Suppl.): 93-105. 
Scott, R. A., Barghoorn, E. S., Leopold, E. B. (1960): How old are the angiosperms? - American Journal of Science, 258-A: 284-299.

Sender, L. M., Doyle, J. A., Upchurch, G. R., Villanueva-Amadoz, U., Diez, J. B. (2018): Leaf and inflorescence evidence for near-basal Araceae and an unexpected diversity of other monocots from the late Early Cretaceous of Spain. - Journal of Systematic Palaeontology, 17: 1313-1346. https://doi.org/10.1080/14772019.2018.1528999

Shi, G., Crane, P. R., Herendeen, P. S., Ichinnorov, N., Takahashi, M., Herrera, F. (2019): Diversity and homologies of corystosperm seed-bearing structures from the Early Cretaceous of Mongolia. - Journal of Systematic Palaeontology, 17: 997-1029. https://doi.org/10.1080/14772019.2018.1493547

Shi, G., Leslie, A. B., Herendeen, P. S., Herrera, F., Ichinnorov, N., Takahashi, M., Knopf, P., Crane, P. R. (2016): Early Cretaceous Umkomasia from Mongolia: implications for homology of corystosperm cupules. - New Phytologist, 210: 1418-1429. https://doi.org/10.1111/nph.13871

Skvarla, J. J., Rowley, J. R., Hollowell, V. C., Chissoe, W. F. (2003): Annulus-pore relationship in Gramineae (Poaceae) pollen: The pore margin of Pariana. - American Journal of Botany 90: 924-930. https://doi.org/10.3732/ajb.90.6.924

Smith, S. Y., Stockey, R. A. (2007): Pollen morphology and ultrastructure of Saururaceae. - Grana, 46: 250-267. https://doi.org/10.1080/00173130701780427

Stampanoni, M., Groso, A., Isenegger, A., Mikuljan, G., Chen, Q., Bertrand, A., Henein, S., Betemps, R., Frommherz, U., Bohler, P., Meister, D., Lange, M., Abela, R. (2006): Trends in synchrotron-based tomographic imaging: the SLS experience. - In: Bonse, U. (ed.), Developments in X-Ray Tomography V. Proceedings of SPIEThe International Society for Optical Engineering, 6318: 63180M (14 pp.). https://doi.org/10.1117/12.679497

Stockey, R. A., Rothwell, G. W. (2003): Anatomically preserved Williamsonia (Williamsoniaceae): Evidence for Bennettitalean reproduction in the Late Cretaceous of Western North America. - International Journal of Plant Sciences, 164: 251-262. https://doi.org/10.1086/346166

Takhtajan, A. (ed.) (1985): Anatomia seminum comparativa. Tomus 1. Liliopsida seu Monocotyledones [Comaparative anatomy of seeds. Volume 1. Liliopsida seu Monocotyledones]. - Nauka, Leningrad, 317 pp. (in Russian)

Takhtajan, A. (ed.) (1988): Anatomia seminum comparativa. Tomus 2. Dicotyledones Magnoliidae, Ranunculidae [Comaparative anatomy of seeds. Volume 2. Dicotyledones Magnoliidae, Ranunculidae]. - Nauka, Leningrad, 256 pp. (in Russian)

Takhtajan, A. (ed.) (1991): Anatomia seminum comparativa. Tomus 3. Dicotyledones Caryophyllidae-Dilleniidae [Comaparative anatomy of seeds. Volume 3. Dicotyledones Caryophyllidae-Dilleniidae]. - Nauka, Leningrad, 240 pp. (in Russian)

Takhtajan, A. (ed.) (1992): Anatomia seminum comparativa. Tomus 4. Dicotyledones. Dilleniidae [Comaparative anatomy of seeds. Volume 4. Dicotyledones. Dilleniidae]. - Nauka, Leningrad, 447 pp. (in Russian)

Takhtajan, A. (ed.) (1996): Anatomia seminum comparativa. Tomus 5. Dicotyledones. Rosidae I [Comaparative anatomy of seeds. Volume 5. Dicotyledones. Rosidae I]. - Nauka, Leningrad, 510 pp. (in Russian)

Takhtajan, A. (ed.) (2000): Anatomia seminum comparativa. Tomus 6. Dicotyledones. Rosidae II. [Comaparative anatomy of seeds. Volume 6. Dicotyledones. Rosidae II]. - Nauka, Leningrad, 455 pp. (in Russian)

Tanrikulu, S., Doyle, J. A., Delusina, I. (2018): Early Cretaceous (Albian) spores and pollen from the Glen Rose Formation of Texas and their significance for correlation of the Potomac Group. - Palynology, 42: 438-456. https://doi.org/10.1080/01916122.2017.1374309

Taylor, D. W., Hickey, L. J. (1990): An Aptian plant with attached leaves and flowers: Implications for angiosperms origin. - Science, 247: 702-704.

https://doi.org/10.1126/science.247.4943.702

Teixeira, C. (1948): Flora mesozóica portuguesa. I parte [Portuguese Mesozoic Flora. Part I]. - Serviços Geológicos de Portugal, Lisboa, 118 pp. +45 pls. (in Portugese)

Tiffney, B. H. (1977): Dicotyledonous angiosperm flower from the Upper Cretaceous of Martha's Vineyard, Massachusetts. - Nature, 265: 136-137.

https://doi.org/10.1038/265136a0

Trevisan, L. (1988): Angiospermous pollen (monosulcate-trichotomosulcate phase) from very early Lower Cretaceous of Southern Tuscany (Italy): some aspects. In: Abstracts, 7th International Palynological Conference, August 1988, Brisbane, Australia, p. 165.

Trincão, P. (1985): Estudo palinostratigráfico do Cretácico inferior Português ante-Albiano [Palynostratigraphic study of the Portuguese Early Cretaceous (pre-Albian)]; Master thesis. - MS, Centro de Geociências da Universidade, Coimbra, Portugal, 103 pp. (in Portugese) (copy in personal library of E. M. Friis, Sweden)

Upchurch, G. R., Dilcher, D. L. (1990): Cenomanian angiosperm leaf megafossils, Dakota Formation, Rose Creek Locality, Jefferson County, southeastern Nebraska. - US Geological Survey Bulletin, 1915: 1-55. https://doi.org/10.3133/b1915

Villanueva-Amadoz, U., Pons, D., Diez, J. B., Ferrer, J., Sender, L. M. (2010): Angiosperm pollen grains of San Just site (Escucha Formation) from the Albian of the Iberian Range (north-eastern Spain). - Review of Palaeobotany and Palynology, 162: 362-381. https://doi.org/10.1016/j.revpalbo.2010.02.014

Villanueva-Amadoz, U., Sender, L. M., Royo-Torres, R., Verdú, F. J., Pons, D., Alcalá, L., Diez, J. B. (2015): Palaeobotanical remains associated with dinosaur fossils from the Camarillas Formation (Barremian) of Galve (Teruel, Spain). - Historical Biology, 27: 374-388. https://doi.org/10.1080/08912963.2014.931385

Walker, J. W., Walker, A. G. (1984): Ultrastructure of Lower Cretaceous angiosperm pollen and the origin and early evolution of flowering plants. - Annals of the Missouri Botanical Garden, 71: 464-521. https://doi.org/10.2307/2399035

Walker, J. W., Walker, A. G. (1986): Ultrastructure of Early Cretaceous angiosperm pollen and its evolutionary im- 
plications. - In: Blackmore, S., Ferguson, I. K. (eds), Pollen and Spores: Form and Function. Academic Press, London, pp. 203-217.

Ward, J. V. (1986): Early Cretaceous angiosperm pollen from the Cheyenne and Kiowa formations (Albian) of Kansas, USA. - Palaeontographica, B, 202: 1-81.

Ward, J. V., Doyle, J. A., Hotton, C. L. (1989): Probable granular magnoliid angiosperm pollen from the Early Cretaceous. - Pollen et Spores, 31: 113-132.

Wieland, G. R. (1906): American fossil cycads. - Carnegie Institution of Washington, Washington, $296 \mathrm{pp} .+$ pls. https://doi.org/10.5962/bhl.title.2088 https://doi.org/10.5962/bhl.title.45272
Wing, S. L., Boucher, L. D. (1998): Ecological aspects of the Cretaceous flowering plant radiation. - Annual Review of Earth and Planetary Science, 26: 379-421. https://doi.org/10.1146/annurev.earth.26.1.379

Wolfe, J. A., Upchurch, G. R. (1987): North American nonmarine climates and vegetation during the Late Cretaceous. - Palaeogeography, Palaeoclimatology, Palaeoecology, 61: 33-77.

https://doi.org/10.1016/0031-0182(87)90040-x

Zavialova, N., Batten, D. J. (2018): Species of the water-fern megaspore genus Molaspora from a Cenomanian deposit in western France: occurrence, sporoderm ultrastructure and evolutionary relationships. - Grana, 57: 325-344. https://doi.org/10.1080/00173134.2017.1417475 